UNIVERSIDADE DE SÃO PAULO

FACULDADE DE FILOSOFIA, LETRAS E CIÊNCIAS HUMANAS

DEPARTAMENTO DE GEOGRAFIA

\title{
DO COMÉRCIO DE RETALHOS À FEIRA DA SULANCA: \\ UMA INSERÇÃO DE MIGRANTES EM SÃO PAULO
}

SUELI DE CASTRO GOMES

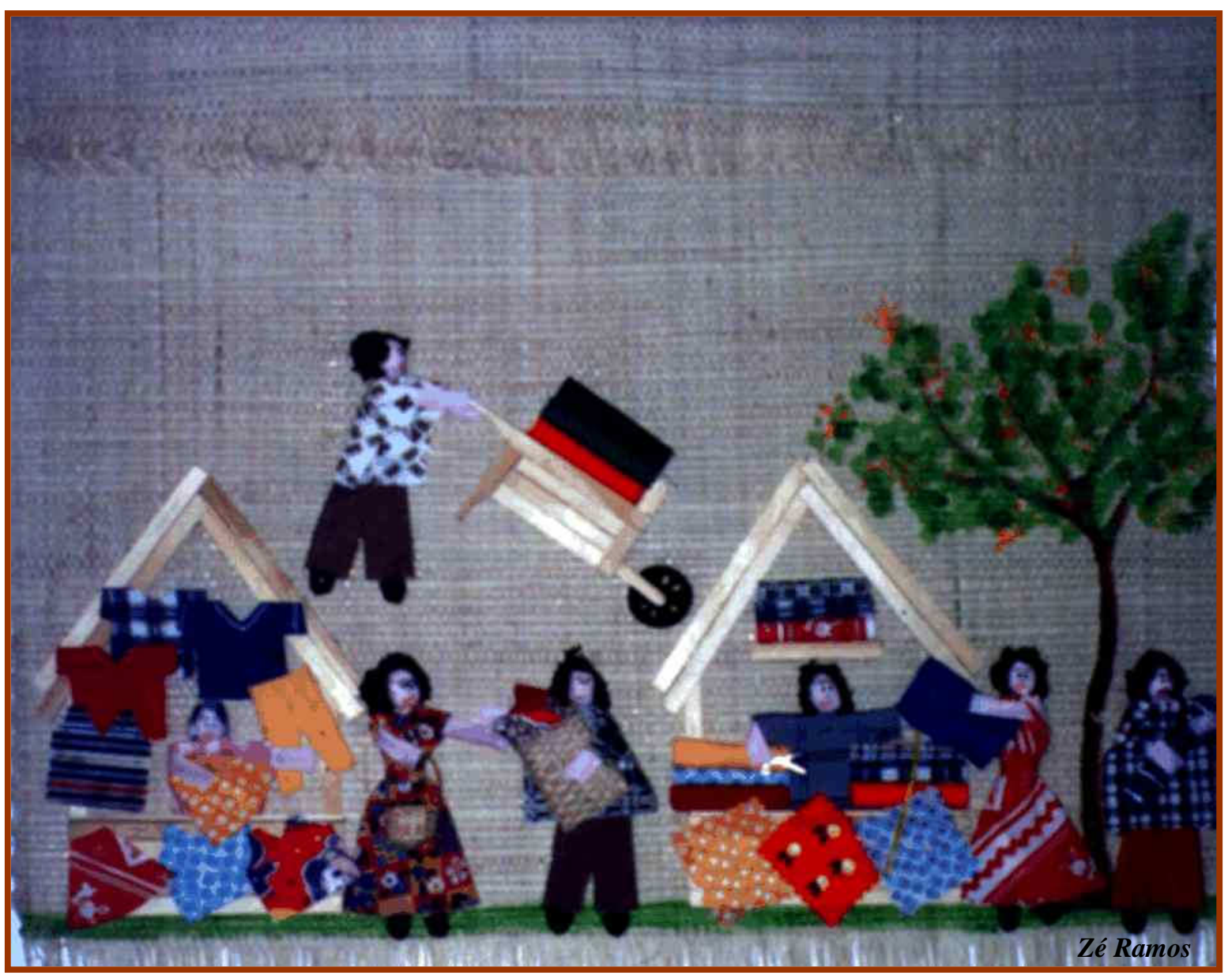

São Paulo

2002 


\section{UNIVERSIDADE DE SÃO PAULO \\ FACULDADE DE FILOSOFIA, LETRAS E CIÊNCIAS HUMANAS \\ DEPARTAMENTO DE GEOGRAFIA}

SUELI DE CASTRO GOMES

DO COMÉRCIO DE RETALHOS À FEIRA DA SULANCA: UMA INSERÇÃO DE MIGRANTES EM SÃO PAULO

Dissertação de Mestrado apresentada ao Programa de Pós-Graduação em Geografia Humana, Departamento de Geografia, Faculdade de Filosofia, Letras e Ciências Humanas - USP, para obtenção do título de Mestre em Geografia Humana, sob a orientação do Prof. Dr. Heinz Dieter Heidemann.

São Paulo

2002 
Dedico este trabalho aos meus pais e ao meu marido, Ary de Araujo Rodrigues Junior, pelo apoio e carinho que recebi nessa jornada. 


\section{AGRADECIMENTOS}

Muitas pessoas contribuíram, direta ou indiretamente com esta pesquisa. Não sei se conseguirei relacionar todos. Contudo, alguns nomes devem ser citados. A todos, os meus agradecimentos.

Ao Prof. Dr. Heinz Dieter Heidemann, que me orientou, pensando sempre comigo as questões conceituais, e assim compondo, de "retalho" em "retalho", buscando "tecer" o meu objeto de pesquisa, mas sem perder "o pano de fundo".

À Profa. Dra. Margarida Maria de Andrade, toda a gratidão, trazendo sugestões de grande valia, enriquecendo com a sua experiência e a sua leitura esta pesquisa.

Um especial agradecimento à Profa. Dra. Iraci Gomes Palheta que me estimulou a trilhar o mundo da pesquisa, incentivando me na graduação e descobrindo comigo, nas ruas do Brás, essa forma de inserção de nordestinos em São Paulo.

À amiga Neusa de Fátima Mariano que acompanhou toda a minha jornada de pesquisa, trocando experiências, angústias, incertezas, auxiliando nas mais diversas e árduas tarefas que a pesquisa exige; desde as cansáveis revisões até os debates teóricos.

À amiga Eli Souza Estrela, a "sampauleira" que se dispôs a ler e a discutir partes deste trabalho, acompanhou me em trabalho de campo, sugeriu leituras de grande valia e me fez pensar, a todo instante, "o que é ser um nordestino em São Paulo".

Aos amigos do grupo do Centro de Estudos Migratórios e Laboratório de Geografia Urbana que contribuíram com diversas sugestões e reflexões que permitiram a pesquisa avançar: Dirceu Cutti, Sidney Dornellas, Sidnei Silva, Vanderlucy, Dulce Batista, Léa, Ana Cristina Nasser, Fábia, Marcos, Herbert, Berenice, Margarida, Neusa. 
Ao meu pai, Sidney, e à minha mãe, Sonia; à minha sogra, Alayde, e meu sogro, Ary por me estimularem nessa jornada, e me apoiarem em decisões difíceis para a realização desta pesquisa. Um agradecimento especial à minha cunhada Simone pelas dicas e outras contribuições importantes para o término da dissertação, e à minha tia Tide, que me auxiliou nas primeiras etapas da pesquisa. À minha tia Maria e prima Bianca pois enriqueceram a dissertação com o seu talento artístico.

Ao meu marido, Ary de Araujo Rodrigues Junior, o meu maior incentivador, que me ouvia, me aconselhava, com a sua paciência, paciência, paciência e carinho ajudando me a realizar esta pesquisa.

Aos amigos, em especial o Roberto, que me apoiou nessa caminhada, ouvindo as minhas angústias e me alentando.

Às pesquisadoras Alexandrina e Mirandulina, pelas primeiras dicas, no início da jornada.

A todos os amigos da Escola de Aplicação, que de uma forma ou de outra me estimularam e apoiaram no desenvolvimento da pesquisa; e em especial, Vanderlei, Jussara e Carmem, que contribuíram diretamente no início do processo.

A minha gratidão em especial aos nordestinos que ajudaram o desenvolvimento da pesquisa, como Assisão de Taperoá, o embaixador da comunidade nordestina, Isaura de Panelas e Tercílio e Terciano de Caruaru.

À família de Caruaru que me acolheu e me deu todo apoio necessário para o trabalho de campo - D. Iracy, Ilmara, João e amigos. Ao apoio e atenção das pessoas de Santa Cruz do Capibaribe. Aos comerciantes retalheiros e tantos outros nordestinos e não nordestinos, que me concederam o seu tempo respondendo às minhas indagações. A todos que com seus depoimentos me permitiram realizar este trabalho.

Às pessoas que me auxiliaram para o término da pesquisa como: Denise, nas transcrições das entrevistas, Sinthia, Neusa, Wagner e Enio pelo auxílio na 
elaboração cartográfica, Luiz Carlos, Jaqueline, que realizaram a revisão geral do texto e à Suely, na produção do abstract.

Aos funcionários da Pós-Graduação em Geografia da FFLCH, Laboratório de Geografia Urbana e Bibliotecas, minha gratidão.

Ao CNPQ pelo apoio financeiro, um ano de bolsa de estudos, viabilizando a realização desta pesquisa.

A todos que, de uma maneira ou outra colaboraram para que este trabalho se tornasse possível e com quem partilho a alegria de ter vencido mais esta etapa. 


\section{SUMÁRIO}

INTRODUÇÃO 11

1 A MIGRAÇÃO DE NORDESTINOS E O BAIRRO DO BRÁS 18

1.1 Os estudos sobre migração e os nordestinos em São Paulo 18

$\begin{array}{ll}\text { 1.1.1 Um passeio pelo Brás } & 18\end{array}$

$\begin{array}{ll}\text { 1.1.2 Os estudos sobre a migração } & 28\end{array}$

1.1.3 Os nordestinos em São Paulo 35

1.2 Brás: bairro de migrante, nascem as inserções 47

1.2.1 A grande imigração

$\begin{array}{ll}1.2 .2 \mathrm{O} \text { bairro italiano } & 60\end{array}$

1.2.3 Bairro nordestino ou o "nó” do Brás? A fragmentação 67

2 O COMÉRCIO DE RETALHOS COMO ESTRATÉGIA DE INSERÇÃO 96

2.1 A formação histórica do comércio de retalhos e o grupo de migrantes 98

2.1.1. Um pouco de sua história - início do comércio e sua evolução 100

2.2 Organização, estrutura e funcionamento do comércio de retalhos 112

2.2.1 As fontes da matéria-prima 112

2.2.2 Das indústrias de confecção e têxteis para os depósitos e lojas 114

$\begin{array}{ll}2.2 .3 \text { Organização do comércio } & 124\end{array}$

$\begin{array}{ll}2.3 \mathrm{O} \text { comerciante de retalhos e resíduos } & 127\end{array}$

$\begin{array}{ll}2.4 \mathrm{O} \text { destino final da mercadoria } & 130\end{array}$

$\begin{array}{ll}2.4 .1 \mathrm{O} \text { transporte } & 134\end{array}$

2.4.2 Santa Cruz do Capibaribe 136

$\begin{array}{ll}2.4 .3 \text { Feira da Sulanca } & 142\end{array}$

$2.5 \mathrm{O}$ circuito inferior: do comércio de retalhos à Feira da Sulanca 165

3. NO ESPAÇO DAS REDES SOCIAIS: O COMÉRCIO DE RETALHOS 171

$\begin{array}{ll}3.1 \text { Quem são os retalheiros? } & 171\end{array}$

3.2 As relações "familiares" de trabalho 172

$\begin{array}{ll}3.3 \text { No espaço das redes } & 175\end{array}$

3.4 Os limites da rede: entre a solidariedade e a concorrência 178

$\begin{array}{ll}3.5 \text { Redes: difusão de informações } & 180\end{array}$ 
4. O TRABALHO AUTÔNOMO E O MIGRANTE 189

$\begin{array}{ll}4.1 \mathrm{O} \text { trabalho por conta própria no comércio de retalhos } & 189\end{array}$

4.2 Hierarquias no interior do comércio de retalhos 192

$\begin{array}{ll}\text { 4.3 Migrante: sujeito sujeitado e o sonho da liberdade } & 195\end{array}$

5 CONSIDERAÇÕES FINAIS 201

6 BIBLIOGRAFIA 205

ANEXO 


\section{LISTA DE FOTOS}

$\begin{array}{ll}\text { F. 1: A estação Roosevelt } & 19\end{array}$

F. 2: A estação ferroviária do Brás 19

F. 3: Vista do Largo da Concórdia 21

F. 4: Lojas de produtos típicos do Nordeste 21

F. 5: Loja com produtos típicos do Nordeste 24

F. 6: Artigos típicos do Nordeste 24

F. 7: Faixa divulgando a atividade organizada pela prefeitura e ANESP 25

F. 8: Hotel Vitória 25

F. 9: A Hospedaria do Imigrante 41

F. 10: Centro de Tradições Nordestinas (CTN) 44

F. 11: Escritório central do grupo Matarazzo 53

F. 12: Os anarquistas $\quad 59$

F. 13: Antiga sede dos anarquistas $\quad 59$

F. 14: Casa 63

F. 15: O cineteatro Politheano 64

F. 16: A Festa de São Vito 66

F. 17: Artigos e produtos servem à comunidade nordestina 71

F. 18: Comércio de alimentos voltados para a culinária nordestina 71

F. 19: A atual ocupação no Largo da Concórdia 72

F. 20: Ônibus de uma agência clandestina de viagem 72

F. 21: Emboladores $\quad 73$

F. 22: Venda de CDs de Forró

F. 23: O comércio em $1940 \quad 85$

F. 24: Padaria de imigrante italiano

F. 25: Ônibus de excursões de sacoleira

F. 26: Caminhão

$\begin{array}{ll}\text { F. 27: Rua Maria Joaquina } & 109\end{array}$

$\begin{array}{lr}\text { F. 28: Vila } & 109\end{array}$

$\begin{array}{ll}\text { F. 29: Rua Joly } & 110\end{array}$

$\begin{array}{ll}\text { F. 30: Rua Almirante Barroso } & 110\end{array}$

F. 31: Depósito de retalho 111

F. 32: Depósito de retalho 111

F. 33: Menino e resíduos 116

$\begin{array}{ll}\text { F. 34: O catador } & 117\end{array}$ 
$\begin{array}{ll}\text { F. 35: Funcionário } & 119\end{array}$

$\begin{array}{ll}\text { F. 36: Corretores } & 120\end{array}$

$\begin{array}{ll}\text { F. 37: Depósito-dormitório } & 120\end{array}$

F. 38: Grande depósito 122

F. 39: Depósito do Sr. Osmar 122

$\begin{array}{ll}\text { F. 40: O Trabalho } & 123\end{array}$

$\begin{array}{ll}\text { F. 41: Comerciante de retalho } & 124\end{array}$

F. 42: Costureira boliviana 132

F. 43: Caminhão no depósito 133

$\begin{array}{ll}\text { F. 44: Transportadoras } & 135\end{array}$

F. 45: Caminhão em Santa Cruz 137

$\begin{array}{ll}\text { F. 46: Rua de atacadistas de tecido } & 137\end{array}$

$\begin{array}{ll}\text { F. 47: Santa Cruz do Capibaribe } & 141\end{array}$

F. 48: Santa Cruz do Capibaribe 144

F. 49: Estacionamento dos ônibus 146

$\begin{array}{ll}\text { F. 50: Feira da Sulanca, anoitecendo } & 148\end{array}$

$\begin{array}{ll}\text { F. 51: Feira da Sulanca, manhã } & 148\end{array}$

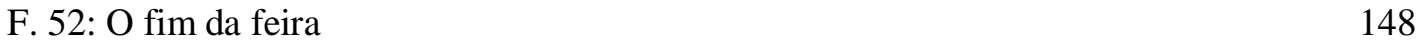

$\begin{array}{ll}\text { F. 53: Feira da Sulanca } & 149\end{array}$

$\begin{array}{lr}\text { F. 54: Sulanqueiro dorme } & 149\end{array}$

F. 55: Maquete do Parque das Feiras 152

F. 56: O churrasquinho 154

F. 57: Antiga feira de Caruaru 155

F. 58: A estação ferroviária de Caruaru 155

F. 59: Vista panorâmica da Feira da Sulanca 156

F. 60: Feira da Sulanca de Caruaru 157

F. 61: Feira da Sulanca de Caruaru 159

F. 62: Barraca-Restaurante 159

F. 63: Estacionamento dos ônibus 160

F. 64: Parque das Feiras 163

F. 65: Oficina de costura 163

F. 66: Migrante de Ibirajuba 182

F. 67: Migrante de Iguatu 182 


\section{LISTA DE FIGURAS E GRÁFICOS}

$\begin{array}{ll}\text { Figura 1: Sistema Metroferroviário } & 81\end{array}$

Figura 2: Localize os Shoppings $\quad 91$

Gráfico 1: Profissões dos Coreanos no Brasil - 1989

\section{LISTA DE MAPAS}

Mapa 1: Presença nordestina no Brás - SP 27

Mapa 2: Munícipio de São Paulo - Localização da área de estudo - Brás 48

Mapa 3: Região Metropolitana de São Paulo - SP $\quad 80$

$\begin{array}{ll}\text { Mapa 4: O comércio de retalhos e resíduos no Brás } & 107\end{array}$

Mapa 5: O pólo da indústria da sulanca 131 


\section{RESUMO}

O comércio de retalhos e resíduos têxteis está localizado nas ruas do Brás, antigo bairro industrial e operário da cidade de São Paulo. Esse bairro, hoje, concentra um grande número de indústrias e lojas de confecções, que vendem no atacado e no varejo para "sacoleiras" de todas as partes do Brasil. O comércio de retalhos vai nascer nos interstícios das antigas indústrias têxteis e, posteriormente, se alimentar do rejeito da indústria da confecção que fornece, diariamente, toneladas de resíduos e retalhos para serem comercializados pelos "retalheiros". Uma parte desses retalhos e rejeitos é comprada por costureiras da Grande São Paulo e até mesmo por "sacoleiras", sendo que a maior parte dessa mercadoria é enviada para Santa Cruz do Capibaribe - cidade do interior pernambucano, que constitui em pólo de confecções de "sulanca". São vestuários de qualidade considerada inferior, consumidos, predominantemente, por uma população de baixa renda. $O$ nordestino de menor poder aquisitivo passa a ser consumidor do rejeito das confecções do Centro Sul.

O comércio de retalhos e resíduos é controlado, predominantemente, por migrantes nordestinos, formando uma rede de pessoas e mercadorias em torno dessa atividade. Desta forma, procuramos estudar como tais migrantes foram mobilizados para trabalhar nesse comércio nas ruas do Brás. Estudamos as transformações do bairro, desde a ocupação dos italianos até a chegada dos nordestinos, no sentido de entender a presença do comércio em suas ruas. Ao identificar as conexões que esse espaço mantém com outros espaços, construindo uma malha de homens e mercadorias, optamos por seguir a circulação da mercadoria - retalho até o seu destino final, qual seja, as feiras da sulanca de Pernambuco.

Dentre as múltiplas problematizações que a pesquisa traz à tona, destacamos as redes sociais como um instrumento mobilizador do migrante comerciante autônomo de retalhos contribuindo para a ampliação do capital.

Palavras-chaves:

Migração - Nordestinos - Brás - Feiras da Sulanca - Santa Cruz do Capibaribe Redes Sociais - Trabalho Autônomo 


\section{ABSTRACT}

Trading cloth patches and textile remainders is carried out in the streets of the Brás neighborhood, an industrial and working class old district in São Paulo. It now concentrates several industries as well as wholesale and retail clothing stores meant for "sacoleiras" coming from all over Brazil. The patch trade originates in the interstices of old textile industries. Later it feeds on refuses of clothing industries that daily supply tons of remainders and patches to be traded by the "retalheiros". These patches and refuses are partly bought both by sewing women in greater São Paulo and by "sacoleiras". Most goods are sent to Santa Cruz do Capibaribe, in the hinterlands of Pernambuco State, which is a "sulanca" manufacturing pole. It merely consists of poorer quality clothing, mostly consumed by a lower income population. The lower income northeastern citizen becomes a buyer of fabric refuses from the Southern Center.

The patch and remainder trade is mostly controlled by northeastern migrants, who form a net of people and merchandise based on this activity. Hence, this dissertation aimed at studying how these migrants were mobilized to work in this trade in the streets of Brás. In order to understand this process, the work also investigated the changes undergone by the district, from the Italian to the northeastern Brazilian occupation on the area. Once the connection among this and other areas was identified by the people/goods net evolution the patch-goods circulation was followed to one of its ends, namely the "sulanca" fairs in Pernambuco.

Among the manifold questions raised by this research, attention should be drawn to the social nets as a mobilizing means of the free-lance migrant, who trades patches that contributes to capital increase.

Keywords

Migration - northeastern migrants - Brás - 'Sulanca' Fairs - Santa Cruz do Capibaribe Social Nets- Free Lance Work 


\section{INTRODUÇÃO}

A pesquisa tem seu embrião na monografia de Iniciação à Pesquisa em Geografia ${ }^{1}$, no ano de 1989. Naquele período, foi desenvolvida uma pesquisa sobre a atividade comercial de retalhos, no bairro do Brás. O propósito inicial era estudar o grupo de migrantes e as questões migratórios que estavam presentes; entretanto, naquele momento nos detivemos apenas à organização do comércio, deixando de lado muitas outras questões pertinentes ao tema. No mestrado, retomamos o projeto anterior, reelaborando a partir de um novo levantamento empírico. Desta maneira, neste estudo, pretendemos refletir sobre o processo migratório e as formas de inserção do migrante em São Paulo, modificando espaços - do Brás à Santa Cruz do Capibaribe.

É muito comum que os pesquisadores, por serem migrantes, se identificarem com o tema e desta forma o escolherem como objeto de estudo. Não foi esse o meu caso, pois não sou migrante, nordestina ou moradora do bairro do Brás. O tema, em um primeiro instante, encantou-me, havendo dificuldade em definir exatamente qual era a minha afinidade com o objeto. Essa indagação me perseguiu por muito tempo, até que, recuperando a minha história de vida, avistei elementos e símbolos presentes que me aproximavam do tema da pesquisa. Os meus avós, tias e mãe sempre trabalharam com costura e eu brincava entre os retalhos e as bonecas de pano. Depois, meu pai que era metalúrgico, passou a trabalhar por conta-própria, em uma loja de calçados. Eu e minha mãe "ajudávamos" nessa empreitada. Trabalhavam conosco balconistas recém-chegadas do Nordeste. Sem construir um patrimônio e desiludido, meu pai retornou ao trabalho assalariado, como operário. Os depoimentos de comerciantes retalheiros traziam falas que podiam identificar-se com as de meu pai. Senti a necessidade de registrar a experiência dos migrantes comerciantes de retalho, tendo como ponto de partida a minha própria experiência no comércio.

O Bairro do Brás, município de São Paulo, é uma área caracterizada pela forte presença de migrantes nordestinos. Dentre outras características que marcam o bairro, destacamos a concentração de confecções, lojas de armarinhos e afins que atraem pessoas de todo o território nacional. Por esse motivo, senti-me atraída a andar pelas ruas do Brás na busca de compreender o processo migratório de nordestinos, bem como conhecer melhor esse "território" das confecções e tecidos.

\footnotetext{
1 Trabalho desenvolvido com o auxílio da Bolsa de Iniciação Científica do CNPQ sob a orientação da Prof ${ }^{a}$. Dra Iraci Gomes V. Palheta: : GOMES, "Vila do Pano": Nos interstícios da Indústria, o pequeno comércio do Brás . 1989
} 
Foi assim que encontrei o comércio de retalhos e resíduos instalado, entre os bairros do Brás e do Pari. As lojas apresentavam amontoados de tecidos coloridos de diversos tamanhos e características. Algumas tinham "rolos" de tecido chamados também de retalhos, peças grandes; outras "lojas" trabalhavam com peças menores que os retalhos, chamados resíduos; outras ainda trabalhavam com os dois. Essas lojas, na sua maior parte, pertencem a um grupo de migrantes pernambucanos. Os mais antigos iniciaram essa atividade na informalidade e hoje, mais capitalizados, fazem parte do comércio formal. Entretanto, nem todos os migrantes estão numa mesma etapa do desenvolvimento do comércio. Os migrantes, novatos, não tendo onde morar, dormem entre os retalhos e trabalham para seus conterrâneos na esperança de um dia ter a sua própria loja. Assim, redes sociais que se formam em torno do comércio de retalhos e resíduos, como meio de inserção do migrante na metrópole de São Paulo.

O refugo das inúmeras confecções existentes no Brás, que no passado era lixo, hoje é aproveitado pelos migrantes como estratégia de sua inserção na sociedade capitalista. Há um grande mercado entre as costureiras da metrópole, assim como na economia da sulanca. A sulanca é uma confecção de baixa qualidade, produzida na sua maior parte em Santa Cruz do Capibaribe e cidades vizinhas, no agreste de Pernambuco; é vendida para a população de baixa renda durante as feiras de Santa Cruz do Capibaribe, Caruaru e Toritama. Os consumidores vêm de várias partes do Nordeste, Norte e Centro-Oeste, compram a sulanca e a revendem. A matéria prima para a confecção da sulanca, resíduos e retalhos, saem às toneladas das ruas do Brás com destino a Santa Cruz do Capibaribe e cidades vizinhas.

O objetivo geral deste trabalho é compreender como se dá a inserção e a permanência dos migrantes nordestinos na Metrópole de São Paulo, por meio do comércio de retalhos. Esses migrantes mobilizam as suas redes sociais para se inserirem nessa forma de trabalho, interrelacionada com o sonho do trabalho autônomo, um componente importante, porque é mobilizador do processo de construção dessa atividade comercial e com os espaços que ela ocupa.

O comércio de retalhos nos faz questionar como o migrante na figura do trabalhador autônomo cria e recria o espaço, na busca da sua inserção na sociedade capitalista. Para a obtenção do entendimento dessa realidade, faz-se necessário desvendar a estrutura e o desenvolvimento do comércio.

A partir do problema central desta investigação, alguns conceitos, como: a estratégia de inclusão, as redes sociais, o trabalhador autônomo, o circuito inferior 
/superior da economia, a circulação de mercadoria e sujeito sujeitado receberam uma maior preocupação, pois podem contribuir para a compreensão do comércio de retalhos como uma estratégia de inclusão dos migrantes no modo de produção capitalista, em São Paulo.

Entre os procedimentos empregados, o trabalho de campo foi determinante em nossa investigação. A observação, a coleta de imagens fotográficas, o levantamento de dados para o mapeamento da atividade e as entrevistas foram fundamentais na construção dessa pesquisa, pois não foi encontrada nenhuma pesquisa sobre o comércio de retalhos especificamente. O trabalho de campo foi realizado tanto no Brás, quanto em Santa Cruz do Capibaribe (PE) e cidades vizinhas, locais de produção e destino dos retalhos, respectivamente.

As entrevistas foram tratadas com objetivo de colher os relatos orais. Ora os depoimentos eram gravados e ora eram anotados, mediante à autorização ou não do depoente. A análise das entrevistas foi feita com o intuito de tentar estabelecer uma caracterização dos migrantes retalheiros. Todavia, foi possível perceber ao longo da pesquisa, algumas singularidades. Pois a relativização dos fatos é uma preocupação que nos acompanhou a todo momento.

No relato oral, segundo QUEIROZ (1991), o pesquisador orienta o narrador sobre os aspectos dos quais ele tratará. Assim, ao propor o tema, o depoente discorria sobre o que era relevante em sua vida. A diversidade do uso de técnicas em um mesmo trabalho enriquece a investigação, como indica a autora. Tínhamos um roteiro preliminar de eixos-temátivos, que foi se modificando ao longo da pesquisa e das novas questões que apareciam nesse processo. Dependendo do perfil do investigado eram conduzidas as questões, mas sempre apoiadas em um roteiro básico de temas. Foram realizadas 22 (vinte e duas) entrevistas com os comerciantes retalheiros, além das entrevistas com antigos moradores do bairro do Brás: o dono de uma transportadora, balconistas das lojas de confecção, catadores de resíduo e papelão e uma ex-sulanqueira e poetisa.

Em Santa Cruz do Capibaribe, realizamos diversas entrevistas e conversas informais com uma diversidade de pessoas: Secretário do Desenvolvimento e Comércio, Presidente da Associação dos Sulanqueiros, Presidente da Associação dos Dirigentes Lojistas, costureiras, sulanqueiros, motoristas de ônibus, sacoleiros.

Usamos também a fonte bibliográfica, que nos apoiou dando um arcabouço teórico para as análises dos processos. Foi, também, realizado um levantamento 
bilbliográfico, em Santa Cruz do Capibaribe e Caruaru; outra fonte escrita que recorremos foram os jornais, revistas e os sites sobre os dois locais que estudamos: o bairro do Brás e Santa Cruz do Capibaribe.

As delimitações apareciam a todo instante que a pesquisa tomava corpo, então algumas escolhas tiveram que ser tomadas para o prosseguimento da pesquisa, como a opção de seguir o destino dos retalhos que iam para Santa Cruz do Capibaribe em detrimento do percurso dos resíduos para as fábricas de estopa e cobertores ou outros usos. À medida que se aprofundam e as leituras e colhíamos os depoimentos, percebíamos que o universo da pesquisa era muito amplo.

Um dos objetivos específicos era construir um mapeamento da rede de relações no comércio de retalhos, entretanto percebemos que o mais significativo era tratar algumas formas de relações que se passavam nessa rede do que nomear os indivíduos que a compunham, mesmo porque os dados eram muito imprecisos nos depoimentos.

A pesquisa tem como norte o método do materialismo histórico e dialético fundamentado em uma concepção materialista e dialética da história da sociedade e do ser social. O espaço é concebido, ao mesmo tempo como condição e como produto da reprodução do capital, como reprodução de força de trabalho direta e indiretamente responsável pela produção de mercadoria. Portanto, são processos sócio-econômicos e relações sociais de trabalho e mercado que dinamizam e constróem os espaços aqui estudados - Brás e Santa Cruz do Capibaribe.

Outro pressuposto importante para compreender a migração é a sua inserção no modo de produção capitalista, baseada na leitura de GAUDEMAR (1973). O autor rediscute a força de trabalho a partir de MARX. A força de trabalho concebida como mercadoria é mobilizada pelo capital. Assim, o deslocamento espacial da pessoa que quer vender a sua força de trabalho é uma estratégia do capitalismo que mobiliza o migrante conforme as necessidades do mercado.

Em MARTINS (1988a) encontramos as contradições presentes na migração. Se por um lado existe uma coerção do capital forçando a migração, por outro lado, para o migrante, ele se liberta da coerção permanente na área de origem. Então, o que é um problema, conforme a concepção da classe dominante, do ponto de vista do migrante, a migração é a solução. O autor chama a atenção para o ponto de vista do migrante e o insere na lógica do capital, da seguinte forma:

"Sobre isso, convém lembrar que a fala do migrante é, quase sempre, dominada pela lógica da mercadoria e do dinheiro, da quantidade, e recoberta pelo fascínio do 
maravilhoso e ilimitado das coisas que podem ser compradas e vendidas. $O$ maravilhoso se torna mais amplo e poderoso em relação àqueles que, justamente, vivem no mundo ilimitado da carência." (MARTINS, 1988a: 6).

Assim, procuramos nesta pesquisa investigar esse migrante que segue a lógica da mercadoria, quer se inserir no capitalismo, estar incluso e fazer parte, no nosso caso como comerciante de retalhos.

Ao longo da pesquisa foram aparecendo, durante os debates e leituras, diferentes definições sobre os conceitos de migração, emigração e imigração. Percebemos que não há um consenso entre os estudiosos e os pesquisadores sobre o tema. Então, resolvemos trazer à tona três formas de definição desses conceitos, tratados conforme as necessidades e os contextos em que se inserem.

A primeira forma de definir os termos imigração e emigração, é a partir da referência de destino e origem, respectivamente. Essas definições são uma convenção utilizada pelos demógrafos em algumas instituições de pesquisas, que têm como base os dados estatísticos, como IBGE - Instituto Brasileiro de Geografia e Estatística , NEPO - Núcleo de Estudos de População.

A segunda forma de conceituação, bastante utilizada nas escolas de ensino médio e fundamental é o uso do conceito de imigração, para tratar o migrante estrangeiro e seu processo, e migração para tratar o migrante nacional e seu processo. Muitas vezes, os conceitos criam 'confusões' entre os professores de História e Geografia e os estudantes que buscam a definição "correta". Veremos essa definição em um livro paradidático, como segue abaixo:

Qual a diferença entre emigrar, imigrar e migrar.(sic) De acordo com o valioso dicionário Aurélio, emigrar (quem emigra, emigra de algum lugar) significa deixar ou sair de um país para fixar-se noutro. Imigrar (quem imigra, imigra para algum lugar) significa entrar em país estrangeiro, em mudança. Por exemplo: no final do século XIX, São Paulo recebeu um dos maiores contingentes de imigrantes de diversos países europeus. Migrar significa mudar-se de um lugar, de uma região para outra. Por convenção utiliza-se o termo migrar para designar o movimento de pessoas que se deslocam dentro de um mesmo país. Por exemplo: na década de 30, São Paulo recebeu um grande fluxo de migrantes vindos de Minas Gerais e da Bahia.” (FREITAS, 1999: 32) 
A terceira forma de tratar esses conceitos é a partir da idéia que a migração reúne tanto a experiência de emigrar, como a de imigrar, portanto, o conceito de migração incorporaria os dois outros conceitos. O emigrante é aquele que deixa um lugar, uma cidade região ou país e o imigrante é aquele que chega a um lugar, uma cidade, região ou país. Assim, tanto o italiano do começo do século, como o nordestino, atualmente, são imigrantes em São Paulo. No avanço dessa discussão e na superação dessa classificação, pesquisadores como SAYAD (1999), se utilizam do termo migrante e tratam do processo migratório, pois consideram que a imigração e a emigração fazem parte do mesmo processo. $\mathrm{O}$ mesmo indivíduo tem a experiência de deixar determinado espaço e chegar em outro espaço, portanto referimo-nos a ele como migrante.

Dessa forma, trataremos em nossa pesquisa os diferentes grupos de migrantes e migrações, como os europeus, os coreanos, os bolivianos e os nordestinos. Em alguns momentos para deixarmos claro de qual grupo estamos nos referindo, especificaremos migrantes nacionais ou migrantes estrangeiros.

Assim, essa investigação procura abordar um grupo de migrantes que adotou como forma de inserção na sociedade capitalista a atividade do comércio de resíduos e retalhos no Brás. Constataram-se as diferentes conexões estabelecidas com outros espaços, na circulação das mercadorias e das pessoas. Existe uma tríade de temas que nos debruçamos mais profundamente para compreender o nosso objeto de estudo: as migrações, o bairro do Brás e o pólo da confeção - sulanca em Santa Cruz do Capibaribe e cidades vizinhas.

Organizamos as diversas temáticas e questões que se apresentavam ao longo do percurso da pesquisa da seguinte maneira:

O capítulo um, A Migração de Nordestinos e o Bairro do Brás inicia-se com os diversos enfoques dos estudos do processo migratório. Estuda-se o processo da migração de nordestinos para São Paulo, no sentido de compreender a presença do grupo de migrantes que controlam o comércio de retalhos. A partir disso buscamos entender a forte presença dos nordestinos no Brás, e acompanhamos as transformações deste bairro, atraindo diferentes fluxos migratórios. Então, surgem as seguintes questões: Por que a atividade do comércio de retalhos nasce no bairro do Brás? Por que é predominantemente exercida por pernambucanos? Por que o Brás atrai e atraiu diversos fluxos migratórios? Como ocorreu a migração de nordestinos para São Paulo, em especial no bairro do Brás? 
O capítulo dois, O Comércio de Retalhos como Estratégia de Inserção, aborda a organização e o funcionamento dessa atividade comercial, sua gênese, sua localização e sua diversidade. Optamos por acompanhar o circuito da mercadoria retalho até a sua realização, levantando os seguintes problemas: Qual o trajeto das mercadorias retalhos e resíduos, da sua gênese ao seu consumo? Quais são as cidades brasileiras que recebem essas mercadorias? Existe uma rede no espaço nacional de fluxo de pessoas e mercadorias? Qual a relação do comércio de retalhos no Brás com as Feiras da Sulanca? Quem são os maiores consumidores de retalhos, resíduos e sulanca?

No capítulo três, No Espaço da Redes Sociais: O Comércio de Retalhos, estudase qual é a importância das redes sociais para esse grupo de migrantes. Quem são esses migrantes? Como se dá a relação entre esses migrantes? Qual é o papel das redes sociais na consolidação da atividade de retalhos? Se é uma relação solidária ou de exploração? Investigando a rede social, buscaremos saber se para o migrante ela é uma estratégia de inserção em São Paulo.

No capítulo quatro, $O$ Trabalho Autônomo e o Migrante, algumas indagações foram o nosso ponto de partida: Como funciona a hierarquia das diferentes funções do comércio de retalhos e os diferentes papéis que o migrante assume nessa atividade? Como o e migrante se relaciona com a economia informal? Quais são os sonhos e as expectativas desse grupo de migrantes? Considerando os diferentes contextos em que o comércio de retalhos se insere, na época da criação (década de 70) e atualmente, o trabalho autônomo é uma opção ou uma condição? O migrante, que se reproduz com a atividade dos retalhos é um sujeito sujeitado?

Os migrantes criam o espaço, na busca de sua inserção, do qual se utilizaram das redes sociais para manter a sua reprodução e a sua permanência nesse novo espaço. Nessa busca pela sua inserção articulado com o sonho do trabalho autônomo eles criaram o comércio de retalhos. Dessa maneira, o comércio de retalho resulta da ação do sujeito migrante, movido pelo sonho da autonomia somado à instrumentalização das suas redes sociais. Entretanto, esse migrante que foi mobilizado pelo capital e possibilita a sua autoreprodução e a ampliação do capital é sujeito na medida que cria mas é também sujeitado na medida que mantém e reproduz o capital. 


\section{A MIGRAÇÃO DE NORDESTINOS E O BAIRRO DO BRÁS}

\subsection{Os estudos sobre migração e os nordestinos em São Paulo}

\subsubsection{Um passeio pelo Brás}

São nove da manhã e estou na plataforma da Lapa esperando o trem metropolitano que me levará até o Brás. A linha da CPTM, a antiga Santos-Jundiaí, transporta a população da metrópole que reside nos municípios de Caieiras, Franco da Rocha, Francisco Morato, Campo Limpo Paulista, Várzea Paulista e Jundiaí e dos bairros periféricos de São Paulo como Perus e Pirituba entre outros até os bairros mais centrais. Essas pessoas usam a ferrovia para se deslocar para o trabalho, para escola e para as suas compras nos centros comerciais. Apesar de não ser o horário de 'rush', tanto a estação como os "vagões" estão cheios. Essa população que vem da periferia da Grande São Paulo, na sua maior parcela é constituída por migrantes e seus descendentes. Nesse horário, encontramos sacoleiras, costureiras ou simplesmente grandes famílias que vão ao Brás realizar suas compras, sempre à procura de uma mercadoria que tenha 'bom' preço.

Ainda consigo um lugar para sentar, pois alguns passageiros descem na Lapa, importante centro comercial e de serviços da parte oeste da cidade, para realizarem as compras, ir à busca de alguns serviços: como médico, dentista, cartório... Outra parte desce na Estação da Barra Funda, onde tem baldeação para o Metrô e também para a linha ferroviária, a antiga Sorocabana, que serve Osasco, Itapevi, Jandira, Barueri... e, ainda, há uma rodoviária que atende algumas cidades do interior do Estado de São Paulo.

Nessa Estação entra uma enorme quantidade de pessoas e, entre elas, o Sr. Zé que se senta ao meu lado e começa a conversar - claro que a conversa se inícia pelo tempo: se vai chover, se vai esfriar...

O Sr. Zé está com 80 anos de idade e pretende ir ao Brás para fazer algumas compras. Ele está vindo de Itapevi, onde mora em uma chácara com a filha. Eu não perdi a oportunidade de pedir-lhe que contasse um pouco de sua história, nessa nossa viagem. Nasceu em Alagoas e veio para São Paulo em 1938. Chegou de navio no Rio de Janeiro, lá, pegou o trem da "Central do Brasil”, e desceu na estação do Brás. 


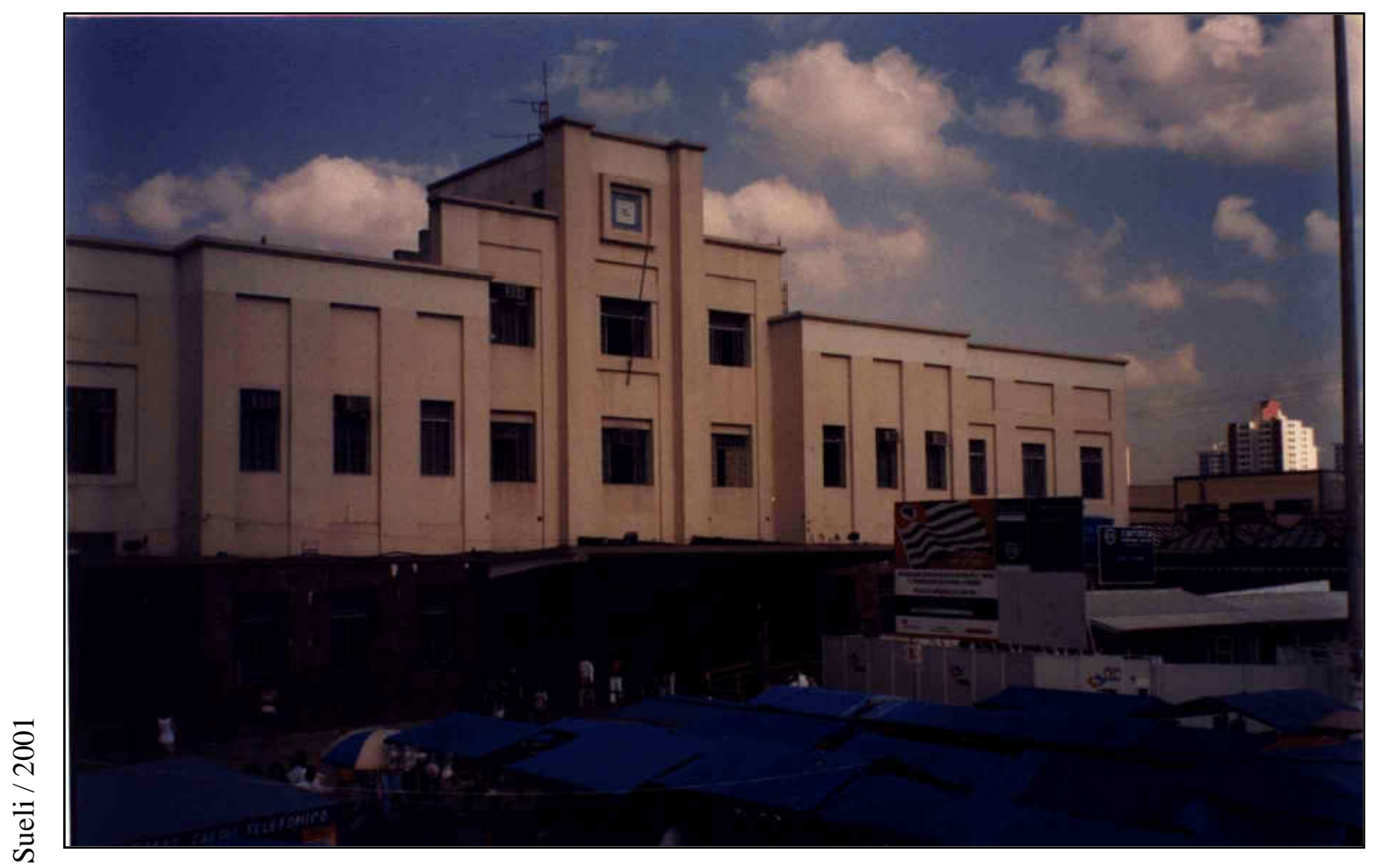

Foto 1: A Estação Roosevelt ou estação do Brás era chamada de "Estação do Norte", onde chegavam os migrantes nordestinos.

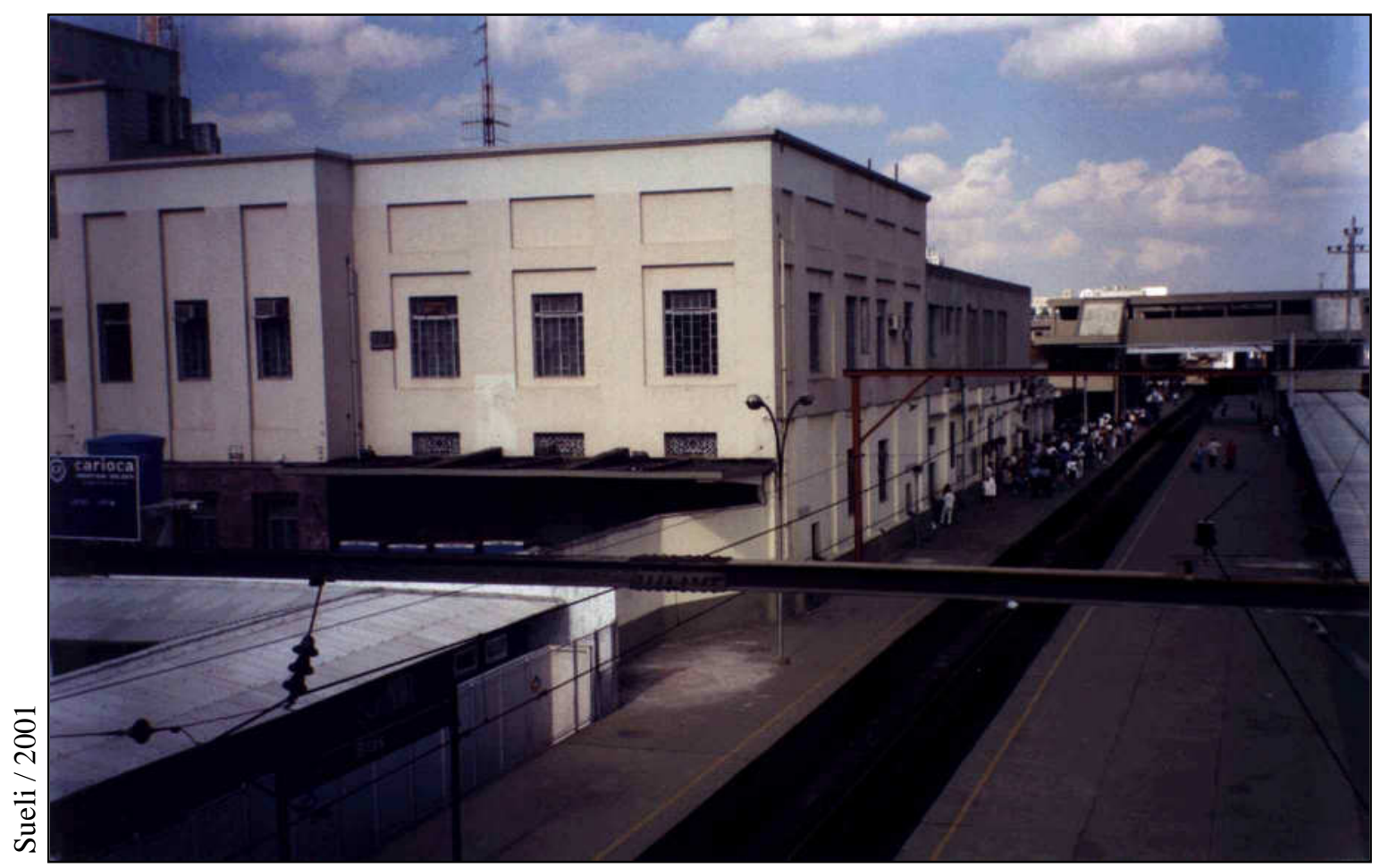

Foto 2: A Estação ferroviária do Brás é um entroncamento de quatro linhas ferroviárias, que interliga a metrópole. Há também uma conexão com o metrô. 
Passou três noites na Hospedaria dos Imigrantes. Conta, com veemência, que vinha com a indicação dos seus conterrâneos para trabalhar na fazenda Santa Rita, no interior do Estado de São Paulo. Apesar do grande número de fazendeiros, que estavam lá na Hospedaria, implorando que os migrantes fossem para as suas propriedades, foi para essa fazenda trabalhar com o algodão e ficar com seus conterrâneos. Ficou lá alguns anos, e depois teve a sua própria roça. Em 1946, resolveu vir morar na cidade de São Paulo... Nossa conversa estava encerrando, pois chegava a nossa estação. Entretanto, ele não deixou de me recitar um cordel, com seus olhos marejados e cheios de lembranças.

A Estação do Brás era chamada antigamente de "Estação do Norte", talvez por ter sido a porta de entrada dos Nordestinos na Grande São Paulo, hoje denominada de Estação Roosevelt.

Essa estação é um entroncamento de várias linhas ferroviárias que servem a região do ABC, Ribeirão Pires, Guarulhos, Poá, Mogi das Cruzes, Itaquecetuba, Osasco, Jandira, e outras tantas cidades da Metrópole, além da baldeação com a linha do metrô. Assim, essa estação é o ponto de conexão de várias partes da metrópole, ligando as periferias ao centro comercial do Brás, ou melhor, trazendo os consumidores periféricos ao comércio do Brás.

Saindo da Estação, encontramos na frente uma enorme e densa quantidade de barracas de camelôs, cobertos por suas lonas azuis, vendendo as suas mercadorias baratas, como 'tênis', camisa de time, comida típica do nordeste, lanches baratos, CDs e fitas piratas, com um som muito alto de forró. Essas barracas cobrem tanto o largo em frente à estação (Praça A. Cícero), como as calçadas das ruas mais movimentadas do Brás e o Largo da Concórdia que, para os antigos moradores, está irreconhecível. "Só tem camelô!". Seguindo pela rua lateral à Estação, a Almeida de Lima, encontramos uma concentração de lojas de alimentos típicos do Nordeste, o que também ocorre nas ruas Cavalheiro e Paulo Afonso. Encontramos a farinha de mandioca, o coco, a carne seca, muito jabá... ou charque, o queijo coalho, o feijão de corda, o camarão, pimenta de todos os tipos, entre as carrancas e as imagens do Pe. Cícero, além de outros artefatos como chapéu de tecido, chapéu de couro, cesta de palha, balaio, rede, berimbau, fumo de corda... São ingredientes que compõem não só um Baião de Dois, mas que compõem os elementos que representam e demarcam a presença do nordestino e seu território nas ruas do Brás. 


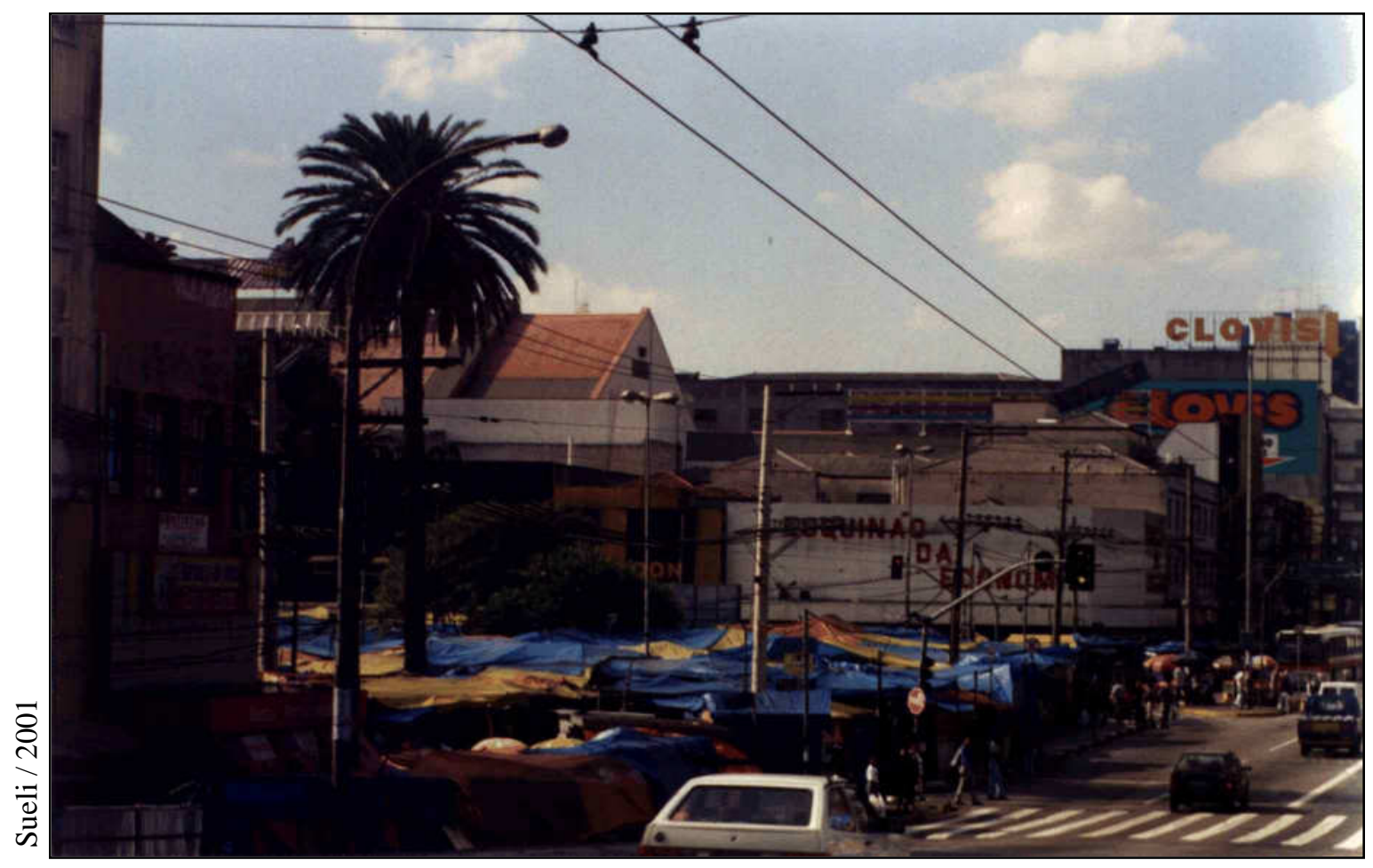

Foto 3:Vista do Largo da Concórdia ocupado pelos camelôs.

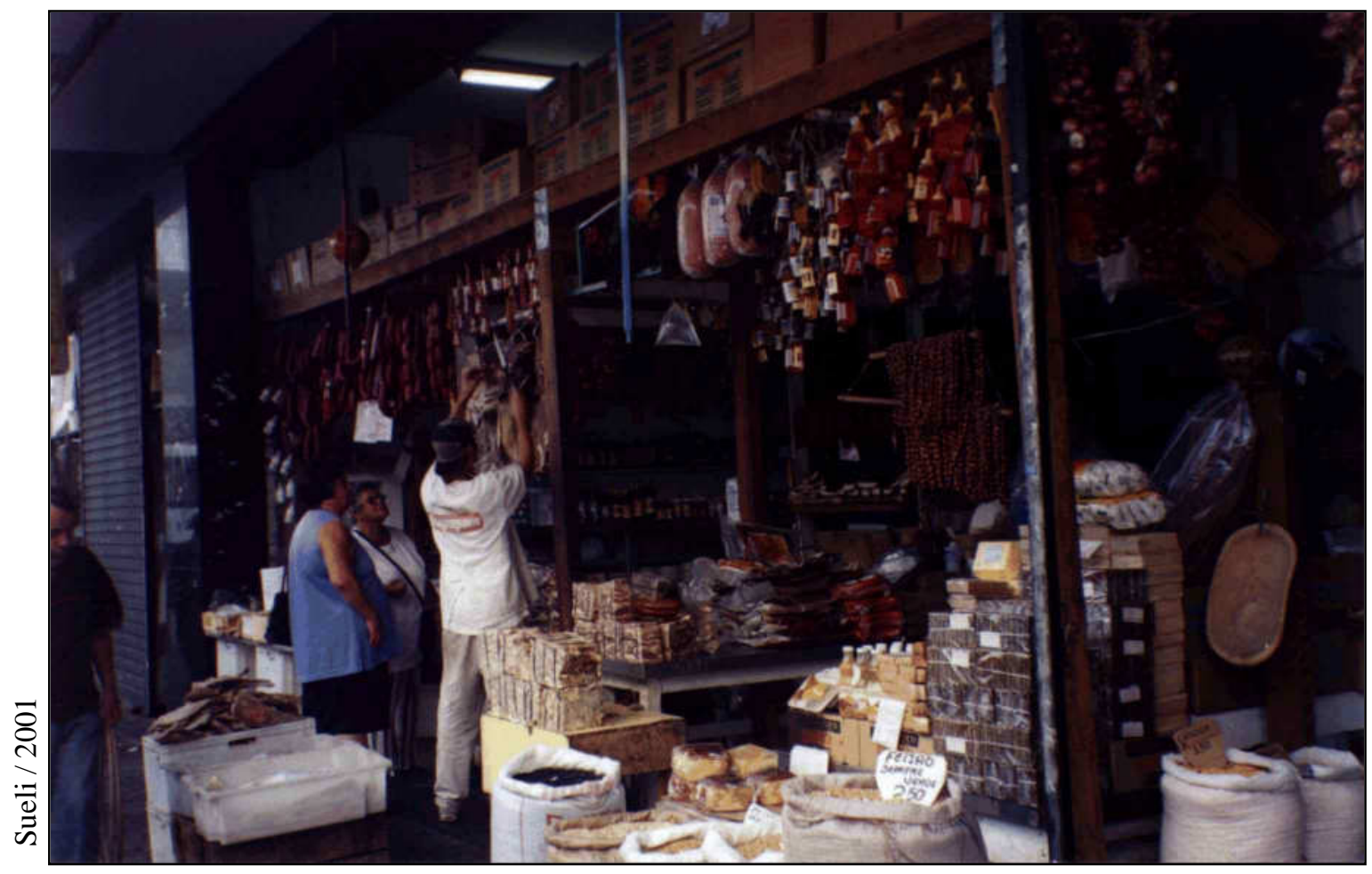

Foto 4: Uma das lojas de produtos típicos do Nordeste localizada na rua Cavalheiro. 
Nas ruas Joaquim Nabuco, Gomes Cardim, Brigadeiro Machado, Vinte e Um de Abril, e as ruas próximas, entre o comércio de alimentos encontramos uma rodoviária clandestina. Muita gente com malas, ônibus envelhecidos e estabelecimentos precários, com mapas pelas paredes, vendendo passagens. Andando pelas calçadas ouvia, pessoas anunciando, com sotaque nordestino, "Passagem para o Norte, passagem para o Norte,..”, "Vai uma passagem aí moça”. Eles pareciam vender uma passagem, como se estivessem vendendo uma tapioca, ou um óculos escuro. A maior preocupação são as condições de segurança desses ônibus. Segundo depoimento do dono de uma empresa legalizada, um paulista, "Eles carregam gente como se carregassem gado". Esse empresário diz que são 35 empresas de ônibus, das quais 3 são legalizadas, o restante é clandestina. O preço de uma passagem que custaria $\mathrm{R} \$ 140,00$ em uma empresa legalizada, custará $\mathrm{R} \$ 70,00$ reais, nas clandestinas. Há uma procura muito grande por essas empresas que servem especialmente às cidades nordestinas. Perguntei ao empresário se o retorno do migrante nordestino está maior do que a sua chegada na cidade. Ele respondeu que não sente diferença no fluxo: “É igual, assim como tem muita gente de partida da cidade, tem muita gente chegando". E acrescentou que já viu muitos que passaram por sua empresa, que vão embora e depois de uns cinco meses, estão retornando - “Muitas vezes são os mesmos”. Essas empresas clandestinas são controladas por nordestinos. Quem sabe outra rede?

Dias depois, a Folha de São Paulo publica uma matéria (27. 05. 2001) sobre as rodoviárias clandestinas, que se localizam não só no Brás, mas em outros pontos da cidade. A publicação estimulou uma maior fiscalização da Prefeitura nessas empresas e gerou uma grande desconfiança desses nordestinos, dificultando um contato mais prolongado para esta pesquisa, bem como para o registro fotográfico.

Na rua Uruguaiana, encontram-se as transportadoras que fazem mudanças e que levam para o Nordeste as mercadorias adquiridas no Brás, inclusive os retalhos, que são objeto de nosso estudo. Há outro grupo de ruas, especializado no comércio de calçados, principalmente tênis e sandálias (parte da rua Cavalheiro, ruas Brigadeiro Machado, e Joaquim Nabuco). Em suma, as ruas se especializam, mas essas atividades comerciais se entrelaçam também com alimentos, transporte de passageiro, venda de malas, carrinhos, calçados. Entre essas atividades, uma série de serviços de apoio: o correio, os bares anunciando as "Comidas do Norte", e uma concentração de hotéis que hospedam os sacoleiros e comerciantes. Dentre esses o hotel Vitória, segundo um dos 
entrevistados nesta pesquisa que hospedou Luiz Gonzaga, quando esse vinha comprar as sanfonas ou fazer os programas de rádio e shows.

Atravessando a Avenida Rangel Pestana, com muita dificuldade para caminhar, devido às barracas, e ao enorme fluxo de pessoas, chegamos à Rua Coronel Trancoso, especializada em lojas de CDs de Forró. A loja mais conhecida é a "Mano Véio e Mano Novo". Ela é a mais tradicional e a que possui uma maior divulgação, pois seus donos possuem um programa na Rádio Imprensa. Em São Paulo, temos três rádios voltadas para o público nordestino e especializadas em Forró - a Radio Capital, a Radio Tropical e a Radio Imprensa.

No entorno das ruas do Largo da Concórdia encontramos os artigos de menor qualidade e mais baratos, vendidos a "baciada". São calcinhas e cuecas, roupas infantis, roupas com costura frouxa, caindo, por vezes, no chão e sendo reviradas, em amontoados, pelas donas de casa à procura do tamanho certo. No meio dessa confusão ficam os rapazes anunciando na calçada, ao microfone, as promoções das lojas, convidando a freguesia para entrar. Os sons se misturam junto ao caos de placas, pessoas, mercadorias. As calçadas são, também, ocupadas por ambulantes que passam com caixas de isopor, vendendo água, refrigerante, suco... O caótico está presente entre o atacado e o varejo de confecções baratas, chamadas pelos pernambucanos de sulanca.

Adentrando esse conjunto de ruas, o artigo das confecções vai melhorando, sempre buscando acompanhar a moda, com seus tecidos, cores e modelos. Observando as pessoas que trabalham nessas lojas, constata-se que a presença maciça de nordestinos vai diminuindo e entre outros, aparecem os traços orientais, sobretudo dos coreanos, que controlam essas confecções. Muitas vezes, eles contratam nordestinos, como balconistas.

Caminhando em direção ao Pari, encontramos o conjunto de ruas onde se concentra o comércio de retalhos e resíduos, o qual escolhemos estudar mais atentamente.

Depois de algumas horas de caminhada, conversas e fotografias, é hora de retornar com o objetivo de evitar o "rush". Voltamos de trem, junto com as sacoleiras, costureiras e consumidores em geral da Grande São Paulo. Eles estão abarrotados de pacotes, sacolas e sacos que anunciam onde foi feita a compra - "Lojão do Brás",... Todos estão muito cansados. Sento-me com uma senhora de Belém que mora em Caieiras, muito contente por ter conseguido comprar pijamas infantis por $\mathrm{R} \$ 3,50$ cada. 


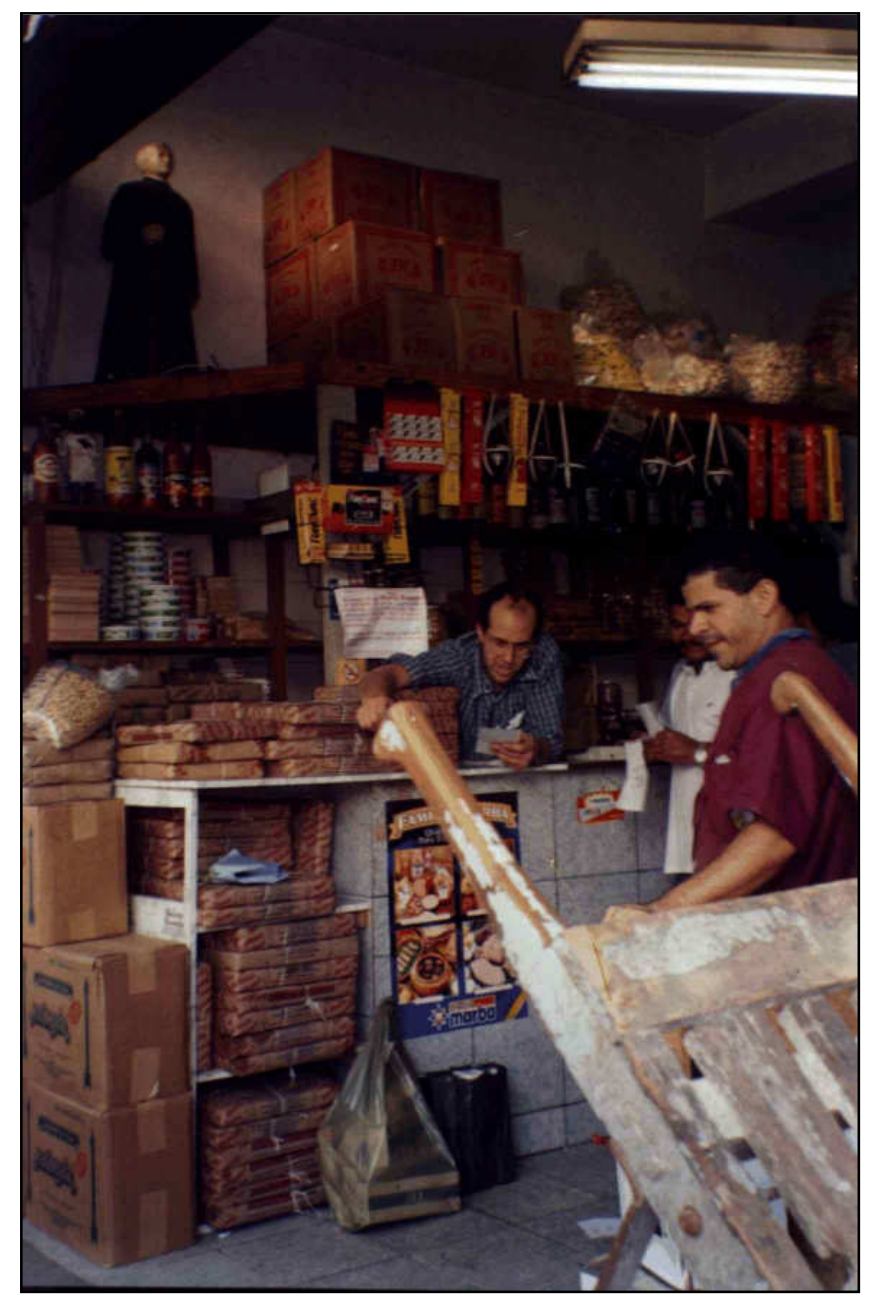

Fotos 5 e 6: Artigos típicos do Nordeste.

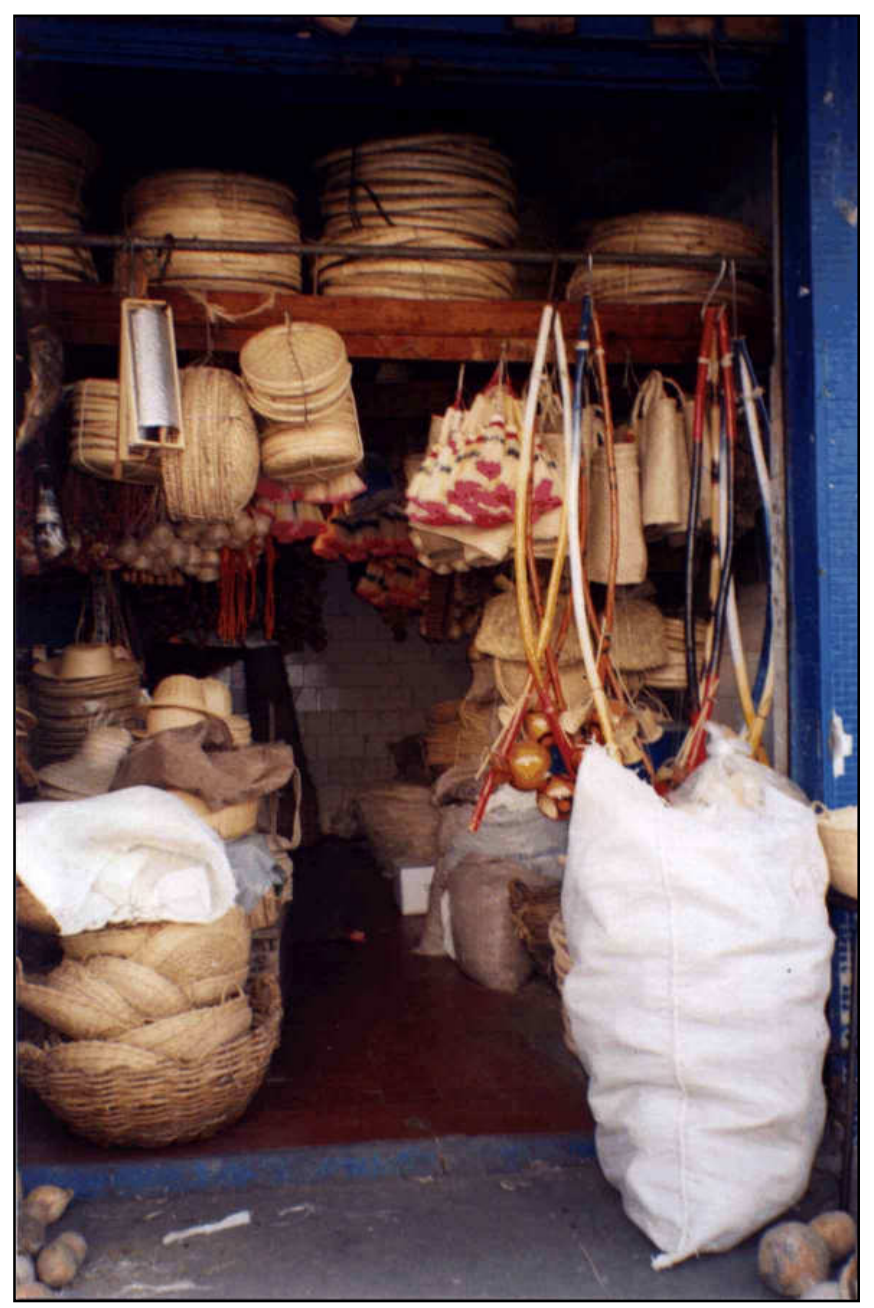




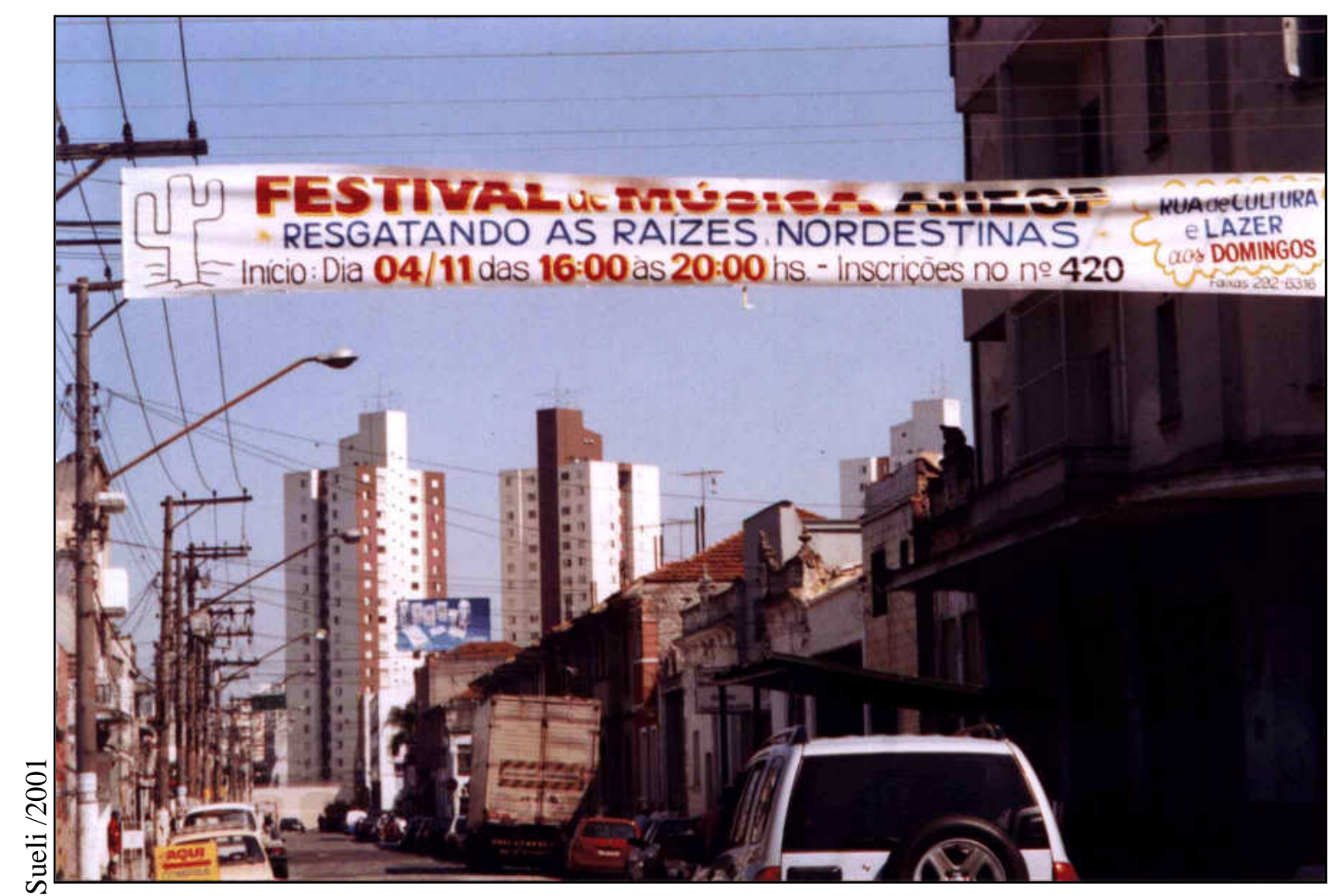

Foto 7: Faixa divulgando a atividade organizada pela prefeitura e ANESP - Associação dos Nordestinos do Estado de São Paulo.

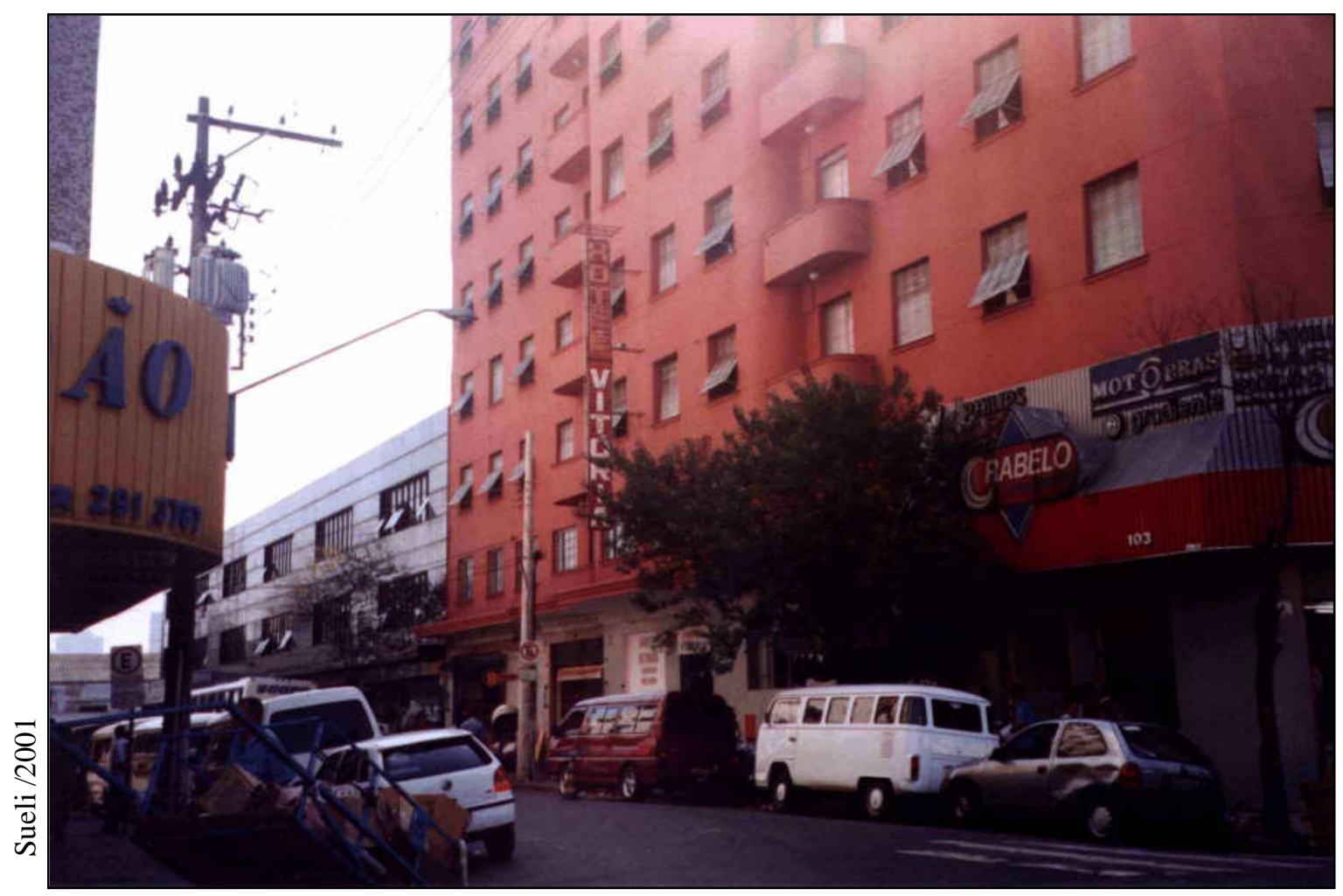

Foto 8: Hotel Vitória, onde se hospedava Luiz Gonzaga e que recebe sacoleiros e comerciantes de várias partes do país. 
Ela vai viajar em breve e está levando suas compras para essa viajem. É comum o migrante, podendo consumir, fazer compras antes de viajar, para presentear os seus parentes e conhecidos, que estão na área de origem. Assim, eu retorno do trabalho de campo como se estivesse voltando de uma viagem a uma cidade do sertão nordestino, depois de caminhar pelas tradicionais feiras, como relata a música de Luiz Gonzaga sobre a Feira de Caruaru (Onildo Almeida - março de1957).

\section{Na Feira de Caruaru:}

\section{A feira de Caruaru}

Faz gosto a gente ver

De tudo que há no mundo

Nela tem pra vender

$\mathrm{Na}$ feira de Caruaru

Tem massa de mandioca,

Batata assada,

Tem ovo cru

Banana, laranja e manga

Batata doce, queijo e caju,

Cenoura, jabuticaba,

Guiné, galinha

Pato e Peru

Tem bode, carneiro e porco

Se duvidar isso é cururu

Tem cesto, balaio, corda

Tamanco, greía, tem boi tatu

Tem fumo, tem tabaqueiro

Tem tudo e chifre

De boi zebu

Caneco, acorviteiro

Peneira, boi

Mel de uruçu

Tem carça de arvorada

Qué matuto

Não andar nú
Na feira de Caruaru

Tem coisa prá gente ver

De tudo que há no mundo

Nela tem prá vender

$\mathrm{Na}$ feira de Caruaru

Tem rede, tem baleeira,

Mó de menino

Caçar nhandu

Maxixe, cebola verde

Tomate, coentro,

Coco e Xuxu

Armoço feito na corda,

Pirão mexido

Que nem angu

Mubília de tamburete,

Feita de tronco

De mulungu.

Tem loiça

Tem ferro véio

Sorvete raspa

Que faz Jaú

Gelado, carnudo e cana

Fruta de Parme

E mandacaru

Boneco de Vitalino

Que são conhecido

Inté no Sur,

De tudo que há no mundo

Tem feira de Caruaru,

A feira de Caruaru... 


\section{PRESENÇA NORDESTINA NO BRÁS-SP}

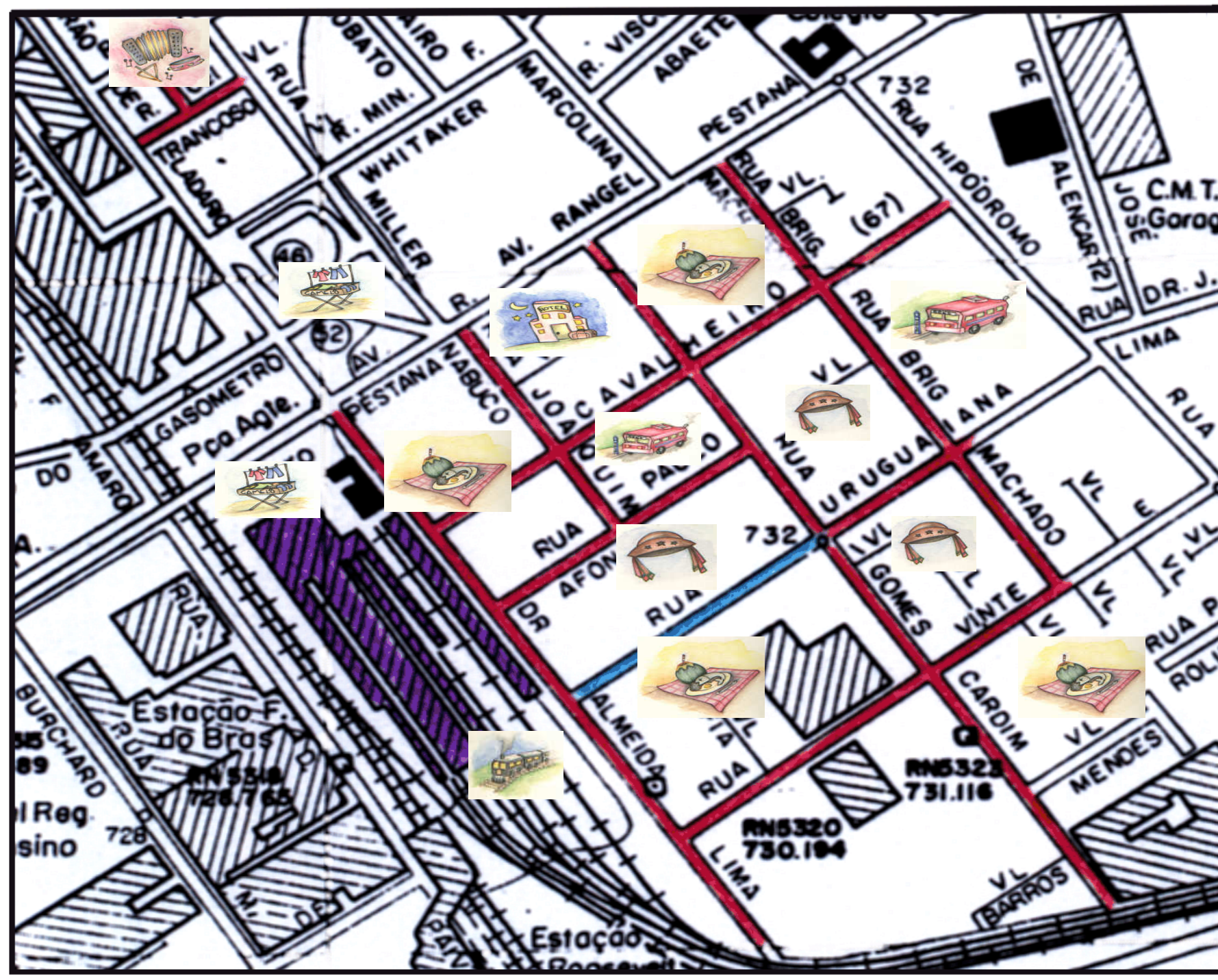

Artesanato

Alimentos típicos do

Nordeste

Rodoviária clandestina

1 토용

frage Hotel

Camelôs

Rulorin: Rua do Forró

\section{Estação Ferroviária}

Comércio de artigos nordestinos

Rua das transportadoras

Estação Ferroviária do Brás

Sem Escala.

Fonte: EMPLASA, 1996. Escala: 1:10.000

Desenho: Bianca Fiorentino

Orgs: Neusa de Fátima Mariano e Sueli de Castro Gomes 


\subsubsection{Os estudos sobre a migração}

As várias pesquisas que lemos sobre a temática migratória revelam a preocupação dos pesquisadores em acompanhar os diferentes enfoques, ao longo do tempo. Assim identificamos nas obras de DURHAM (1973), SINGER (1973), PALMEIRA (1977), MARTINS (1986), MARTINS (1988), BISON (1995), SILVA (1997), BAPTISTA (1998), ESTRELA (1999) VAINER(2000), SALIM (1992), PÓVOA NETO (1997), a preocupação em recuperar a trajetória dos estudos sobre a migração e as diferentes contribuições para entender o fenômeno migratório nos dias de hoje.

Os estudos migratórios ganham um caráter científico, a partir da segunda metade século XIX, quando Ravenstein publica, em 1885, As leis da migração (MOURA, 1980). Essa pesquisa trata da migração interna na Inglaterra e aponta uma grande preocupação com os dados quantitativos. $\mathrm{O}$ autor vê esse fenômeno como uma forma de alcançar um equilíbrio sob o ponto de vista econômico, demográfico e social. É um estudo neoclássico que servirá de mote para muitos outros estudos, que concebem o movimento migratório como fator de equilíbrio, dentro de uma perspectiva de um balanço de custos e benefícios. O enfoque privilegia, basicamente, a decisão de migrar do indivíduo, atraído pelo trabalho. Como mostra os estudos realizados por SALIM (1992):

"Sendo conseqüência das diferenças regionais, a migração tem papel decisivo na eliminação dessas mesmas diferenças, atuando como fator corretivo dos desequilíbrios sócio-econômicos no espaço. É o mecanismo que restaura o equilíbrio e, como tal, otimiza a oferta e a procura entre diferentes setores $e$ subespaços, incidindo positivamente nos níveis de produtividade econômica e, principalmente, nos diferenciais regionais quanto às condições de emprego e de renda”. (p. 123)

No segundo momento, aparecem os estudos com a abordagem históricoestruturalista. Sua reflexão está centrada mais no fenômeno social das migrações e nos contextos históricos e geográficos. Os grupos e as classes sociais sofrem a influência das estruturas sociais. Enquanto que o estudo neoclássico estava centrado no indivíduo, considerando o seu deslocamento como uma decisão individual, os estudos estruturais privilegiam o sujeito coletivo, o processo e suas relações sociais. SALIM (1992) destaca o seguinte: 
“O indivíduo e o grupo social não atuam de forma autônoma, mas submetidos aos influxos de causas estruturais.” (p. 127)

Dentre os autores que trabalham com essa concepção incluímos SINGER (1973), DURHAM (1973), OLIVEIRA (1981), que serviram de apoio para entendermos o contexto de nossa pesquisa.

Em relação às pesquisas histórico-estruturais, a crítica aparece no sentido de mostrar que muitos estudos não consideram alguns aspectos como a cultura, a experiência de vida dos migrantes, as representações, as redes sociais, destacando apenas a estrutura como a determinante. Entretanto, conseguimos encontrar alguns estudos que conseguem contemplar o micro e o macro, como o trabalho de ESTRELA (1999) e BISON (1995). Na dissertação de Mestrado de BISON (1995) que estuda a migração das empregadas domésticas provenientes do Vale do Jequitinhonha, a autora consegue articular as relações sócio-econômicas, os processos dinâmicos contraditórios, historicizando-os, sem perder a noção do indivíduo e seus relatos orais, seus sonhos e desejos. ESTRELA (1999) estuda o fluxo de baianos que migraram para São Paulo, os chamados "Sampauleiros", utilizando-se de aspectos do cotidiano inseridos na estrutura econômica. Essas pesquisas recentes mostram a possibilidade de enxergarmos o indivíduo em uma estrutura econômica, visão pela qual decidimos orientar a nossa investigação. O conceito de redes sociais, ao que tudo indica, permitirá uma aproximação maior da totalidade de nosso objeto. Alguns autores que destacam a importância dessa discussão são MIGUEZ (1995), RAMELLA (1995), BAPTISTA (1998), PÖVOA-NETO (1997), pois esse conceito traz a possibilidade de uma maior articulação entre o indivíduo e a estrutura que esse está inserido. O mapeamento desse indivíduos que compõem a atividade comercial, trouxe a importância da rede social, como um apoio para a inserção do migrante no meio urbano e explicitou outras redes que se formam como a rede territorial e a rede econômica, conforme discutiremos nos capítulos que se seguem.

Segundo BISON (1995), no Brasil e na América Latina, além desse último enfoque, haviam estudos que destacavam o paradigma teórico da Modernização, segundo o qual, o deslocamento populacional saído do meio rural ("atrasado") e dirigido para o meio urbano (evoluído) implicava em "... uma passagem do tradicional ao moderno manifestando, em última instância, o percurso do desenvolvimento do capitalismo nessas sociedades" (p. 33). A crítica a esses trabalhos, que se filiam à 
denominada "Escola Cepalina", se deve ao fato de considerarem o subdesenvolvimento como uma etapa do desenvolvimento.

A terceira abordagem destaca o conceito de mobilidade do trabalho, discutido por Gaudemar (1977), ao abordar a produção e a circulação da força de trabalho. O autor, apoiado na leitura de Marx, elabora o conceito de mobilidade do trabalho, partindo das premissas de que a força de trabalho é uma mercadoria, que está subjugado ao capital. Seguindo essas reflexões, o autor se preocupa, fundamentalmente, com a idéia da força de trabalho a que os homens se prestam, suportando diferentes variações de duração, intensidade e produtividade.

Entender a mobilidade do trabalho é ir além dos deslocamentos espaciais dos homens ou dos seus homólogos setoriais ou profissionais, é apreender os processos desses deslocamentos, percebendo como os homens submetem o seu comportamento às exigências do crescimento do capitalismo. Abaixo, Gaudemar afirma:

“... eu ponho em jogo realmente a 'mobilidade do trabalho'”. O uso capitalista das disponibilidades dos homens, da docilidade (Foucault) dos seus corpos." (p. 17)

Suas reflexões foram influenciadas pela obra de Michael Foucault, quando este discute o poder nas microesferas e a situação dos manicômios. Gaudemar traça um paralelo desse poder e o domínio do capitalismo sobre os homens.

"O trabalhador move-se apenas ao serviço da máquina e do capital que possui. Num tempo e num espaço que é desapossado (...) está sujeito aos movimentos alternativos da expansão do capital.” (p. 35)

$\mathrm{O}$ autor reafirma mais adiante:

“... a disciplina capitalista assegura a repartição dos indivíduos no espaço...” (p. 50)

Mais um fragmento que registra esse paralelo entre o capital e o poder:

"Estratégia de polarização e de intensificação produtivas do lucro, em que os homens, os seus corpos e os seus espaços de vida não passam de instrumentos de valorização do capital.” (p. 58)

Esses fragmentos da obra de Gaudemar vão destacar os deslocamentos dos homens ao ritmo do desenvolvimento da acumulação do capital, sendo esses homens 
"móveis" e de corpos dóceis. Enfim, a origem do processo de produção confunde-se com o processo de produção da mobilidade do trabalho. Ela é a condição e o apoio que dão a sustentação ao processo de produção capitalista, na medida em que o uso capitalista dos corpos dos trabalhadores é requerido para uma maior produção (nas localidades, condições de intensidade e ritmos de produção). Vejamos a citação do autor:

"Na sua dimensão espacial, ela assegura a repartição dos indivíduos no espaço na sua dimensão profissional, constitui o postulado implícito de toda nomeclatura dita homogênea, portanto de toda codificação das atividades; na sua dimensão produtiva mais geral, ela conduz a todo os processos pelos quais o capital dispõe das forças de trabalho e as usa na multiplicidade dos processos de extorsão da mais valia tanto absoluta como relativa. A mobilidade do trabalho surge assim como trave mestra de toda a estratégia de desenvolvimento capitalista.” (p.51)

O Capital mobilizará um exército de homens para a sua reprodução, explicando os deslocamentos populacionais, os grandes fluxos de pessoas que buscam as "melhores condições de vida". Essa mobilidade não é apenas espacial, mas pode ser setorial, no trabalho como confirma PÓVOA (1997). Dessa forma, a teoria da mobilidade do trabalho nos ajuda a entender o deslocamento dos nordestinos para São Paulo:

“A mobilidade se liga à reprodutividade e à expansão física do capital, apresentando-se como condição e conseqüência do desenvolvimento das forças produtivas. Por seu papel essencial no processo de acumulação, as condições em que ela se manifesta podem retratar a própria natureza do ciclo econômico, na medida em que permite o uso extensivo da força de trabalho pelo capital." (SALIM, 1992: 128).

A citação abaixo reforça o significado da migração no sistema capitalista:

"Toda estratégia capitalista de mobilidade é igualmente de mobilidade forçada”.(GAUDEMAR, 1977: 17)

A teoria da mobilidade da força de trabalho identifica três momentos no processo de acumulação: produção, utilização e circulação. Assim, mobiliza a mão-de-obra, leva 
à divisão do trabalho e à sua submissão ao capital. Então, fica ela à deriva das condições do mercado, podendo se deslocar novamente para seguir o movimento do capital.

“Assim, surgem pólos de atração que se concretizam pela mobilidade particular contigente da força de trabalho" (SALIM, 1992: 129).

As ruas do Brás, onde se concentra; entre outras atividades, o comércio de retalhos, são um pedaço de São Paulo, pólo de atração para contigentes de migrantes nordestinos, entre outros. Esse conceito de mobilidade do trabalho permitirá articular o econômico com outros processos sociais, a exemplo do trabalho de BISON, sejam tais processos tidos como culturais ou políticos. Vejamos abaixo:

"O foco de análise não recai apenas sobre as estratégias de subordinação dos trabalhadores ao capital (movimento de cima para baixo), mas, também, sobre as contra estratégias de insubordinação daqueles a este”. (BISON, 1995: 36)

Nesse sentido, identificam-se as contradições. Nossa pesquisa, contudo, não busca no grupo estudado esse movimento de resistência; ao contrário, percebemos que existe um movimento no sentido de fazer parte do modo de vida instaurado sob o capitalismo. A partir daí, caminharemos em busca de outros conceitos como o de "inclusão" (MARTINS,1998) e o de "sujeito sujeitado" (KURZ,2000) para podermos explicar a nossa totalidade.

O conceito de estratégia de inclusão foi explicitado nas reflexões que MARTINS realizou no Simpósio da Pastoral do Imigrante e que tem o propósito de alertar para o sentido do termo excluído.

"Na sociedade capitalista, a rigor, não pode haver exclusão; não pode existir sociedade capitalista baseada na exclusão. Toda dinâmica dessa sociedade se baseia em processos de exclusão para incluir”. (MARTINS, 1998:19)

O autor continua essa reflexão, que será o apoio teórico para o entendimento do nosso objeto.

“Há duas portas para se entrar nessa sociedade. Uma é a porta mais geral da transformação de todos em produtores e vendedores de mercadorias. Tudo tende a ser reduzido à mercadoria. Essa redução de tudo a produtores e consumidores de mercadoria significa que todos, para se integrarem na sociedade capitalista, devem ser transformados em trabalhadores ou, então, 
em compradores de força de trabalho. Em segundo lugar devem ser todos transformados em consumidores dos produtos produzidos por essa mesma sociedade”. (MARTINS, 1998: 20)

Para entendermos melhor seu pensamento, vejamos:

"Nesta sociedade, não há como sobreviver sem se tornar consumidor, ainda que consumidor de menor riqueza do que aquela em cuja produção se esteve envolvido. Portanto, há um componente ilógico na noção de exclusão." (MARTINS, 1998: 20)

O conceito de inclusão traz uma nova reflexão aos estudos migratórios, pois questiona a idéia da exclusão utilizada pelos movimentos sociais. Estes colocam o migrante excluído do capitalismo ou dos seus bens de consumo. Essa reflexão sobre a inclusão aponta o processo migratório, ou melhor, o migrante como um elemento "proposital" incluso no capitalismo, reafirmando-o.

Buscando avançar, recorro a outro conceito que responde o entendimento da migração como parte do capitalismo, é o conceito de sujeito sujeitado, formulado por KURZ que explica a sujeição do indivíduo ao Sistema Produtor de Mercadoria, assim denominado pelo mesmo autor (KURZ, 2000).

Esses conceitos e reflexões são pertinentes a um estudo do migrante como trabalhador autônomo. O trabalho por-conta-própria, já foi estudado anteriormente por MENEZES (1990), PRANDI (1978), LIMA (1987) e outros, que estudaram os camelôs. Nos estudos de SILVA(1997) sobre os bolivianos em São Paulo, há uma constatação desse "deslumbramento" do migrante em ser trabalhador por-conta-própria. Também GAUDEMAR, no momento em que discute as lutas da imigração, em sua obra faz essa ponderação:

"Por mais forçada que possa ser a partida, a imigração é também muito largamente interiorizada pelos imigrantes como meio de acumulação individual destinada a assegurar o regresso ao país, quer como pequeno investidor, pequeno comerciante, quer como artesão. A exploração forçada é freqüentemente suportada na medida em que, no fim, há a imagem de uma casa, de uma camioneta, de uma garagem, de uma pequena loja. Daí resulta a ambigüidade de muitas situações.” (GAUDEMAR,1977:40) 
Assim, o exame dos estudos sobre migrações, bem como a consideração de analises sobre as mudanças recentes nas estratégias de expansão do capitalismo auxiliaram no entendimento do nosso objeto de estudo. HARVEY (1993) fez referência em seus estudos à flexibilização dos mercados, dos processos de trabalho e dos padrões de consumo, mostrando o lado perverso do processo migratório, vejamos abaixo:

"A transformação da estrutura do mercado de trabalho teve como paralelo mudanças de igual importância na organização industrial. Por exemplo, a subcontratação organizada abre oportunidades para a formação de pequenos negócios e, em alguns casos, permite que sistemas mais antigos de trabalho doméstico, artesanal, familiar (patriarcal) e paternalista ("padrinhos, “patronos" e até estruturas semelhantes à da máfia) revivam e floresçam, mas agora como peças centrais, e não apêndices do sistema produtivo.(...). O rápido crescimento de economias "negras", "informais" ou "subterrâneas" também tem sido documentado em todo o mundo capitalista avançado, levando alguns a detectar uma crescente convergência entre sistemas de trabalho 'terceiromundistas' e capitalistas avançados.” (p.145)

O autor destaca o retorno de formas antigas, que normalmente são controladas por grupos de imigrantes nas grandes cidades, que representam coisas bem diferentes em diferentes lugares.

“Às vezes, indicam o surgimento de novas estratégias de sobrevivência para os desempregados ou pessoas totalmente discriminadas (como os haitianos em Miami ou Nova Iorque), enquanto em outros casos existem apenas grupos imigrantes tentando entrar num sistema capitalista, formas organizadas de sonegação de impostos ou atrativo de altos lucros no comércio ilegal em sua base. Em todos esses casos, o efeito é uma transformação do modo de controle do trabalho e de emprego."(p.145).

A atividade comercial, objeto do nosso estudo, é uma forma de migrantes obterem sua acumulação individual. Esse mesmo migrante foi mobilizado pelo capital e "suporta" a mobilização forçada, enquanto "vislumbra a possibilidade de adquirir os bens almejados como também abrir seu próprio negócio...”(SILVA, 1997: 62). Existe o aumento crescente da mão-de-obra migrante, que se submete a salários aviltantes e péssimas condições de vida. O lado perverso desse processo se mostra quando 
encontramos uma parte dos migrantes, que vivem no "mundo do retalho", submetendose a péssimas condições de vida, como aqueles que dormem em cima dos próprios retalhos: as mercadorias se confundem - homens e retalhos.

O comércio de retalhos representa a "liberdade" para o migrante, que esconde o constrangimento do seu deslocamento forçado, como bem coloca o autor abaixo:

“A suposta 'liberdade' de movimento resulta, em muitos casos, em perda da própria espacialidade ou mesmo das condições objetivas de existência de determinadas camadas sociais. Reporta-se, em última ratio, às próprias condições de reprodução da força de trabalho, no quadro de aprofundamento das relações capitalistas." (SALIM, 1992: 128)

A intenção, nessa parte do trabalho, foi perceber as mudanças que ocorreram nas abordagens dos estudos migratórios, partindo dos estudos neoclássicos, passando por uma concepção estruturalista e aprofundando a reflexão por meio dos estudos recentes. Estes avançam, quando abordam os elementos do cotidiano e da cultura, entre outros. É importante destacarmos o risco da classificação dos autores em uma corrente de estudos. A classificação acaba reduzindo e simplificando de tal forma, que pode nos distanciar do 'significado' da obras. Mesmo enfrentando esse obstáculo, optamos por registrar, de uma forma didática e cronológica, essas referências bibliográficas, que fazem parte de nossa caminhada e de nossa preocupação metodológica. Nossa investigação, que tem um caráter empírico, esteve sempre apoiada na teoria social e econômica, buscando os processos que envolvem nosso objeto, abordando alguns conceitos que clarificam as filigranas, que vão permear esta pesquisa.

\subsubsection{Os nordestinos em São Paulo}

O entendimento da presença maciça dos nordestinos na metrópole de São Paulo só é possível, quando estudamos o processo de formação econômica do espaço brasileiro e a reprodução ampliada do capital.

Tanto a compreensão das áreas de expulsão desses migrantes, quanto da área de atração faz parte do mesmo processo. Para desvendá-lo, seguimos os passos de OLIVEIRA (1981), sob a ótica da divisão regional do trabalho e criticando o conceito 
dos "desequilíbrios regionais". A "região" é fundamentada na especificidade da reprodução do capital. Há

“... uma tendência para a completa homogeneização da reprodução do capital e de suas formas, sob a égide do processo de concentração e centralização do capital, que acabaria por fazer desaparecer as “regiões”, no sentido proposto por essa investigação. Tal tendência quase nunca chega a materializar-se de forma completa e acabada, pelo próprio fato de que o processo de reprodução do capital é por definição desigual e combinado,...” (p. 27)

Esse marco teórico será a referência do autor acima para explicar o desenvolvimento desigual e combinado do Nordeste e do Centro-Sul. E que possuem formas diferentes de desenvolvimento do capital. A partir das transformações sofridas nessas regiões ele analisa essa complementaridade entre elas.

O Nordeste "açucareiro" se transforma em Nordeste "algodoeiro-pecuário" subordinado ao mercado internacional. Essa economia formou uma classe latifundiária, que possuía o controle político local, os chamados "coronéis". "Nesse rastro é que surge o Nordeste das secas" (p. 35). No Centro-Sul havia a oligarquia dos Barões do Café, que seguia a mesma estrutura de subordinação do Nordeste, viabilizando a reprodução do capital atendendo os interesses do mercado externo. "A "região" do café passa a ser a "região da indústria: São Paulo é o seu centro, o Rio de Janeiro o seu subcentro,...”(OLIVEIRA.1981: 37). Tanto no Nordeste, como no Centro-Sul existe uma mudança nessa estrutura e há um enfraquecimento do poder local e das economias regionais, os chamados "arquipélagos" ligados a uma economia externa são substituídos por uma economia integrada. Essas transformações ocorrem a partir de 1930 e são resultado de uma política centralizadora, fortalecendo o Estado unificado.

A concentração fundiária, concomitante à modernização do campo somada às mudanças nas relações de trabalho e de poder, provocam uma grande expropriação e estimulam a grande emigração, agravadas nos ciclos das secas. Nesse mesmo tempo, o Centro-sul se transforma em um grande pólo de atração pela dinâmica de sua economia.

“A conversão da região do café em 'região da indústria começa a redefinir a própria divisão regional do trabalho em todo o conjunto nacional. Seu papel nessa divisão regional do trabalho no que respeita à região Nordeste passa a ser de um lado, sistematicamente, a reserva do exército industrial de reserva: 
as migrações Nordeste - São Paulo chegam a constituir um formidável contingente que vai suprir os postos de trabalho criados pela industrialização, e contribuir para manter baixos os níveis de salário real de toda a massa trabalhadora; ..." (OLIVEIRA.1981:37).

A leitura de SINGER (1973) reforçou a teoria das desigualdades regionais como o motor das migrações internas, as quais acompanham a industrialização das regiões mais desenvolvidas. A divisão regional do trabalho aponta para a interdependência dessas regiões. Há uma subordinação econômica das regiões que exportam matéria-prima e mão de obra (o chamado exército de reserva) e importam os produtos industrializados de outra região. SINGER discute a migração interna a partir dessa reflexão e faz uma leitura da urbanização brasileira, principalmente de São Paulo:

"A mobilização deste exército de reserva se fez paulatinamente, entre 1930 e 1945, a partir da abolição da autonomia dos estados, que serviu tanto para unificar o mercado interno como derrubar oligarquias locais, cujo poder sobre a população rural foi consideravelmente enfraquecido. A construção de uma rede de rodovias, que passou a interligar as principais regiões do país, facilitou as comunicações e estimulou enormemente as migrações internas." (p. 122)

A cidade de São Paulo concentrou um grande número de indústrias. A investigação de SINGER explica a presença da industrialização em São Paulo. O ciclo do café trouxe à cidade alguns elementos, como a ferrovia, bancos, mão-de-obra, mercado regional, entre outros, que vão servir de apoio para as primeiras indústrias nacionais. Vejamos a seguir:

"O fator isoladamente mais importante que privilegiou São Paulo como zona industrial é a sua situação geográfica, que lhe assegurou acesso a uma área, onde se encontrava a maior parte do mercado interno brasileiro. Fatores puramente geográficos, estudados sobretudo por Caio Prado Jr., como indicamos acima, tornam tributária de São Paulo uma ampla área do país, que ultrapassa as fronteiras do atual Estado de São Paulo. Os laços que ligam esta área à cidade de São Paulo foram reforçados pelo sistema ferroviário, construído para atender ao escoamento do café, o sistema São Paulo Santos.” (SINGER, 1974: 51) 
Não há dúvida que a integração do espaço nacional, por meio de ferrovias e rodovias, acelerou e estimulou a migração interregional, aumentando deliberadamente o número de nordestinos em São Paulo. Outros elementos contribuíram para a expansão dessa migração como a política trabalhista de Getúlio Vargas que regulamentava algumas reivindicações do operariado, entre elas o salário mínimo. Os salários nas áreas urbanas eram um atrativo à migração interregional, pois os ganhos salariais, apesar da legislação federal, eram e são diferenciados. Outro fator significativo é a política migratória, em 1930, para a qual Getúlio Vargas propõe uma lei de cotas, que desestimula a imigração externa. Ele assina um decreto que limita “... em 1/3 o número de trabalhadores estrangeiros por empresa, é dado um passo decisivo para que os trabalhadores nacionais superem em número os estrangeiros na composição da classe operária.” (ALBUQUERQUE Jr., 1990: 28).

Outro aspecto que devemos destacar nesse processo é evidenciado no documento elaborado pelo governo em um projeto apresentado à República Federal Alemã in: SUDENE-BOLETIM ECONÔMICO, vol. 1, 1962 - “a crescente pressão demográfica que se destaca no Nordeste tem suscitado problemas sociais e políticos de suma gravidade..." (Apud OLIVEIRA, 1981: 114). O texto segue citando o aparecimento de associações camponesas, ou seja, havia uma pressão social para a distribuição de terras, que se não fosse "resolvida" poderia estourar em grandes movimentos sociais, reivindicando a Reforma Agrária. A válvula de escape que o governo encontrou foi estimular a emigração, desafogando e desarticulando possíveis movimentos sociais. Assim "as migrações internas apareciam antes como solução do que como problema." (VAINER, 2000: 25)

A teoria da mobilidade do trabalho, formulada por GAUDEMAR (1977), nos ajuda a compreender melhor a migração de nordestinos para São Paulo, cujo enfoque está na produção e na circulação da força de trabalho. O processo de produção capitalista se viabiliza na medida em que ocorre o deslocamento espacial dos nordestinos para São Paulo. Esse grupo forma o denominado exército industrial de reserva, que é um excedente de mão de obra, mantendo os salários baixos, devido ao excesso de mão de obra. Gaudemar elabora essa teoria a partir das análises de Marx sobre a reprodução do capital. 
"A análise da obra de Marx leva Gaudemar a designar, como mobilidade do trabalho, a qualidade que permite o uso capitalista dos corpos dos trabalhadores, nas localizações, condições de intensidade e ritmos de produção requeridos para a máxima produção de valor. Não se trata apenas de uma descrição de deslocamentos espaciais de trabalhadores; mais que isso, o conceito marxista de mobilidade do trabalho refere-se à "trave mestra de toda a estratégia de desenvolvimento capitalista" (APUD: PÓVOA NETO, 1995: 19)

O Capital mobilizará um exército de homens para a sua reprodução, explicando os deslocamentos populacionais, os grandes fluxos de pessoas que buscam as "melhores condições de vida". Essa mobilidade não é apenas espacial, mas pode ser social. Quando dimensionamos o contexto, em que os nordestinos estão inseridos, vemos as condições políticas econômicas e sociais, que "excluem" grande parcela dessa população dos elementos vitais de sua sobrevivência. Constatamos que essa migração é uma mobilidade forçada, uma estratégia que o capital usa para a sua reprodução. $\mathrm{O}$ capital acaba designando a esse grupo as áreas de destino, ou os chamados pólos de atração, que no nosso caso será São Paulo.

"Toda estratégia capitalista de mobilidade é igualmente de mobilidade forçada”. (GAUDEMAR, 1977: 17)

Os registros dos primeiros migrantes nordestinos em São Paulo datam aproximadamente de 1901; o Estado recebeu nesse ano, 1434 migrantes internos frente aos 70.348 migrantes estrangeiros. (BOSCO e JORDÃO NETO, 1967: 10)

Os migrantes nordestinos incentivados pelo Estado, se alojavam na mesma estrutura que muito foi usada para a recepção dos imigração estrangeiros, a Hospedaria dos Imigrantes construída na gestão de Antonio de Queiroz Telles como Presidente da Província, inaugurada em 1887, no bairro do Brás (ANDRADE, 1994) questão que será tratada a seguir. A edificação enorme, com capacidade em alojar cerca de 4 mil pessoas $^{2}$, documenta a política pública de incentivo ao fluxo, arregimentando a mão de

\footnotetext{
${ }^{2}$ Segundo Reale (1982) a hospedaria passa a abrigar 2000 pessoas. No Catálogo publicado pelo Memorial do Migrante (1997) afirma que sua capacidade é para receber 3.000 pessoas. "em ocasiões especiais chegou a abrigar até 8.000 de uma só vez." (p. 5)
} 
obra barata para suprir o rápido crescimento da cafeicultura, embora muitos fiquem na capital para atender às necessidades urbanas em expansão. Na Hospedaria, os nordestinos pernoitavam por um ou dois dias, eram submetidos a uma triagem que consistia em verificar seus documentos, suas condições de saúde e o local de destino.

Atendendo às necessidades dos cafeicultores, o Estado cria em 1939 o Departamento de Imigração e Colonização, vinculado à Secretaria de Indústria e Comércio. O objetivo era o de conduzir os imigrantes nacionais às fazendas de café; estima-se que no ano de 1939 ingressaram no Estado paulista 100 mil nordestinos e mineiros. Há uma queda nesse fluxo na década de 40, em virtude de um novo ciclo extrativo da borracha na Amazônia. Essa diminuição continua, em 1950, pois tanto a economia cafeeira declinou quanto as necessidades econômicas de São Paulo se transformaram. Jordão Neto relata em entrevista realizada, em 1995, pelo grupo de estudos do Labur - USP/CEM:

"Iniciamos o trabalho no Departamento e ainda havia algum movimento de imigrantes. A partir de 1960 foi arrefecendo, e hoje, a migração decaiu. Quase todas as corrente migratórias passavam pelo Departamento de Migração e colonização. O pessoal vinha, desembarcava de trem na estação Roosevelt, estação do Norte, e os imigrantes que vinham de Santos já desciam diretamente no Departamento, pois ali havia uma estação. Até aquele momento tinha um significado, o Departamento de Migração e Colonização. Ocupava um papel relevante, pois era um termômetro da própria economia. Media o circuito, os círculos migratórios, registrava o movimento e sabíamos quando significava uma situação de crise lá no Nordeste com a diminuição da população; mas também podia estar significando um fator de atração momentânea, relacionada ao círculo vegetativo das culturas do estado de São Paulo. Sempre no início do ano o afluxo era grande por causa das colheitas, mês de julho caía bastante, depois, a partir de setembro/outubro, começava a crescer outra vez." (Jordão Neto -18/08/95)

Nessa entrevista, o sociólogo Jordão Neto, destaca o grande fluxo no "alvorecer dos anos 30", com a expansão dos cafezais e também da cultura do algodão, que estava requisitando mais mão de obra. Esse relato conta que até 1919 havia uma crise violenta de "braços" e então o Estado vai estimular a imigração interna - “Em 1919, o próprio governo do estado chegou a mandar uma missão para o Ceará, para recrutar mão de 
obra." Já em 1935, o governo do estado de São Paulo celebra contratos com companhias particulares de imigração, de colonização, com o objetivo de aumentar o número de migrantes nacionais, "mediante uma subvenção oficial”. Essas Companhias iam aliciar no Nordeste e norte de Minas Gerais pessoas interessadas em vir para São Paulo - "Pagavam a passagem e 60 mil réis por migrante avulso, maior de 12 anos, e 30 mil réis por menores de 3 a 12 anos."

Em 1939, o próprio Estado faz esse aliciamento, criando a Inspetoria de Trabalhadores Imigrantes. Os funcionários da Secretaria de Migração e Colonização ficavam instalados nos terminais ferroviários de Montes Claros e de Pirapora, nas localidades portuárias, ao longo do percurso dos gaiolas no São Francisco. Muitos problemas ocorriam, como o favorecimento e o assédio sexual. De lá, embarcavam as famílias, que seriam recebidas na Hospedaria do Imigrante. Alí os fazendeiros recrutavam os migrantes para irem trabalhar na lavoura no interior de São Paulo. “Havia uma orientação de que os migrantes não poderiam ficar na capital”. O relato de Jordão Neto vai ao encontro da conversa que tive com o Sr. José, nordestino de 80 anos que chegou em São Paulo em 1938, e foi trabalhar na cultura do algodão, conforme deixei registrado no início.

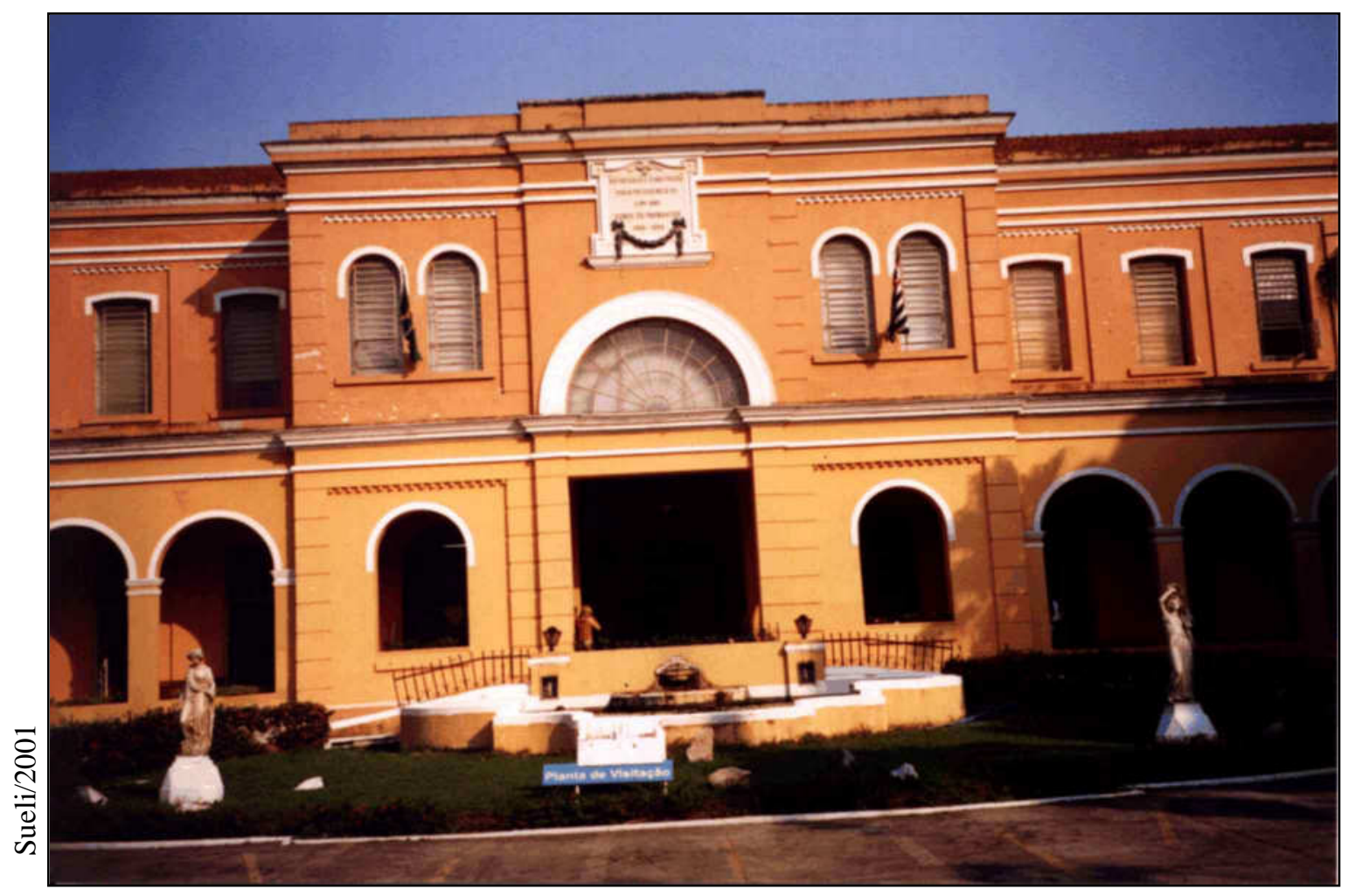

Foto 9: A Hospedaria do Imigrante, fundada em 1887. Hoje é o Memorial do Imigrante. 
Esse aliciamento pelo Estado ocorrerá até 1943, pois nesse período, a Hospedaria passa para o Ministério da Aeronáutica. "Embora a inspetoria continuasse a funcionar, a coisa era caótica, porque as pessoas que ali chegavam eram alojadas em pensões, ali da própria região do Brás”. Essa situação perdurou até 1952. Depois disso há uma alteração no quadro de registros desses migrantes, que não necessariamente passam pela Hospedaria, porque já têm outros pontos de apoio, como os familiares. A orientação de mandar a pessoa para o interior deixa de existir e as pessoas acabam permanecendo na capital, pois o quadro econômico também é outro. A situação no campo também se modifica: em 1965, vigora o Estatuto do Trabalhador Rural e não há mais interesse de trazer gente para morar na fazenda, os expulsos tornam-se os bóias frias, que vão engrossar a periferias das cidades.

O estudo do Centro de Estudos Migratórios faz uma síntese sobre a migração dos nordestinos, na qual registra:

"A título de ilustração vejamos: dos 404. 960 trabalhadores nacionais chegados a São Paulo entre 1941 e 1949, 94,5\% seriam lavradores. (Bosco e Jordão Neto, 1967: 100). Até 1951, 95\% dos nordestinos dirigiram-se para a lavoura.

A partir da década de 50, o fluxo de migrantes orienta-se fundamentalmente em direção às cidades, sobretudo para a região metropolitana de São Paulo. Um estudo efetuado numa fábrica paulistana abrangendo os anos de 1956-58, revelou que 1/4 dos operários não qualificados elou semi-qualificados era formado por nordestinos." (CEM, 1988: 8)

Então, o Departamento de Migração e Colonização começa a atuar na capital com o sentido de atender também os indigentes e os desempregados. Essa mudança na política de atendimento ao migrante, como bem disse em entrevista Jordão Neto ${ }^{3}$ (18.08.95):

“O problema surgiu quando a migração deixou de ser uma solução para ser um problema (...). O Estado investiu, a economia investiu. No momento que

\footnotetext{
${ }^{3}$ Em entrevista concedida ao grupo de estudos migratórios em 18.08.95, em que eu estava presente.
} 
deixou de ser uma solução para ser um problema, 'deixou' de haver os serviços".

Outro fator importante, nesse deslocamento é a mudança do meio de transporte: ferroviário para o rodoviário. "Para se ter uma noção da importância da Rio-Bahia como via de 'êxodo', basta atentar para o fato de que em 1950, somente $12 \%$ dos migrantes, entravam em São Paulo por via rodoviária; em 1961 cêrca de 34\%" (BOSCO, 1967: 26). Foram muito utilizados os chamados "pau-de-araras", caminhões e depois os ônibus. $\mathrm{O}$ relato dessas viagens e desse cotidiano encontramos na pesquisa de ESTRELA (1999), revelando os diferentes percursos, a alimentação, as bagagens, o vestuários, e as diversas dificuldades dessa vinda para São Paulo.

A recepção aos nordestinos em São Paulo, desde os precursores até os dias atuais, sempre foi carregada de muita discriminação e preconceito, estigmatizando-os como "Bahianos" ou "Cabeça Chata". O estudo de Maura Penna (1992) que vai tratar da identidade do nordestino, aborda o preconceito que esse grupo enfrenta. A autora faz um levantamento na imprensa de diversos artigos e situações, na época em que a paraibana Erundina vence as eleições para a prefeitura, que mostram a xenofobia dos paulistanos.

O crescimento urbano de São Paulo está relacionado diretamente ao fenômeno migratório, e este, aos processos de urbanização e industrialização. O fluxo migratório nacional de maior destaque foi o dos nordestinos para São Paulo.

Segundo BAPTISTA (1998:32) a participação dos migrantes nordestinos, no total de imigrantes em São Paulo em 1950, era de 27,8\%, em 1974 de 49\%, em 1982 de 56\% e em 1997 de $46 \%$.

Para se ter uma dimensão desse universo, ÂNGELO (1996) afirma que existem mais de 200 pontos de encontro de Nordestinos na cidade de São Paulo. Eles estão espalhados por toda cidade, incluindo os restaurantes e casas noturnas. ${ }^{4}$ Ele faz um levantamento minucioso dos restaurantes, casas noturnas, e até lojas que vendem discos, cds e livros ligados à cultura nordestina. A primeira casa no gênero a ser inaugurada foi o forró de Pedro Sertanejo, foi no começo dos anos 60. Outro local de destaque é:

4 Além das centenas de Casas do Norte, espalhadas por toda cidade, destacamos, algumas casas como: A Galinhada do Dema (Canindé), o restaurante Andrada (Pinheiros), Recanto do Picuí (Anhanguera), Recanto Nordestino (S.Joaquim), Embaixada Nordestina (Osasco), Bambulê, Mercadão da Cantareira, Tropical (Butantã), Brasileirão, Brilho da Lua (Brás- Av. Celso Garcia), Estrela do Forró (Brás- R. Cel 
"Na zona Norte (rua Jacofé), há o concorrido Centro de Tradições Nordestinas (CTN); na zona Leste, o tradicional Forró de Pedro Sertanejo e o Espaço do Forró mantido pela prefeitura, com entrada grátis. No bairro de Santana, há Um Cantinho do Nordeste e a lanchonete Boa Viagem...”. (p. 119120)

O autor completa:

“Nesses pontos reúnem até 20 mil pessoas a cada fim de semana, chova ou faça sol, frio ou calor. É uma barulheira dos diabos, mas os freqüentadores não ligam, parece até que não se importam muito com o desconforto, que, aliás, é grande.” (p. 120)

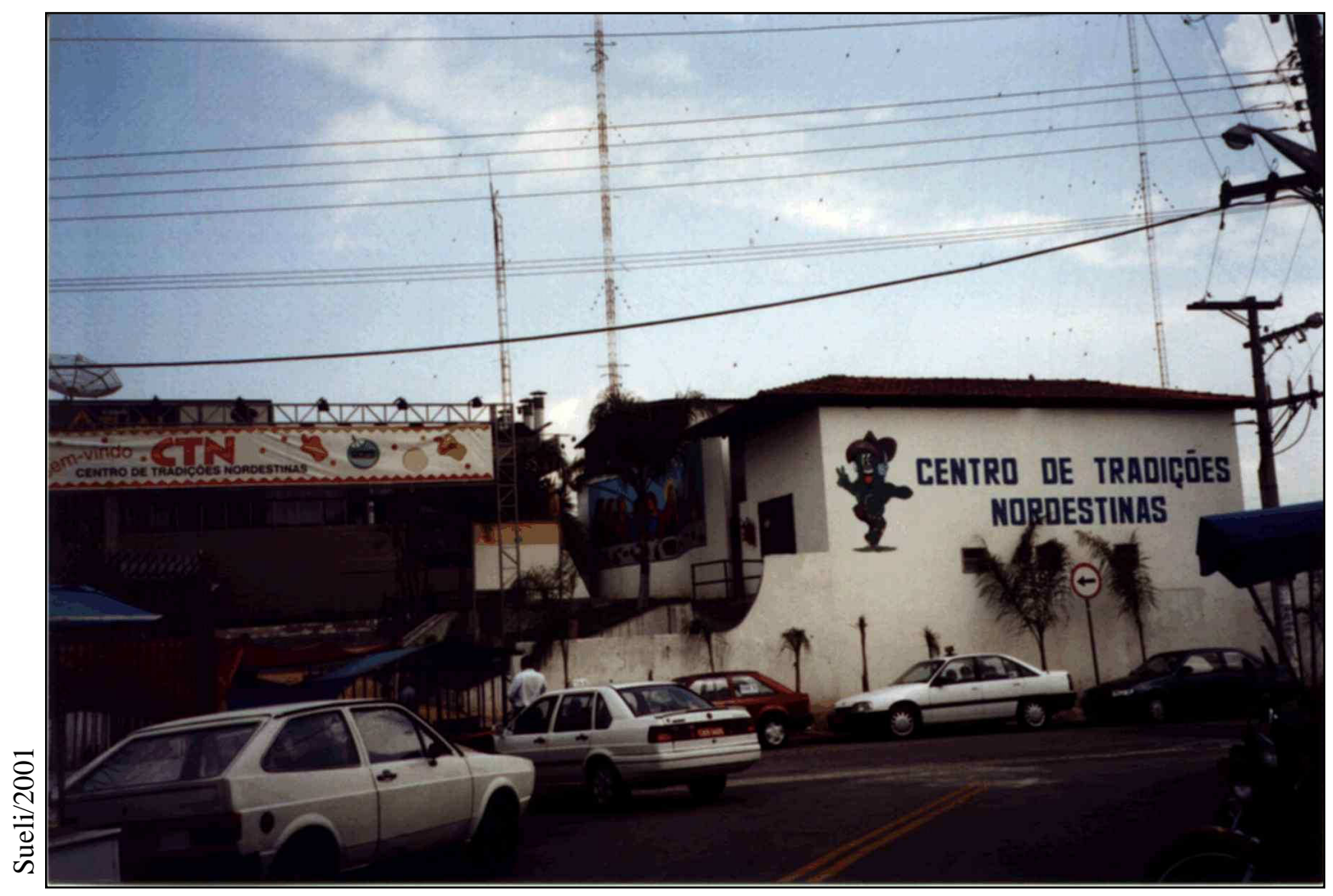

Foto 10: Centro de Tradições Nordestinas (CTN).

Trancoso), O Patativa (Santo Amaro) reúne cerca de 20 mil pessoas, Prainha do Forró (Guarapiranga), Ceagesp (Jaguaré). 
Sobre o CTN encontramos um artigo na Revista Travessia que mostra a dinâmica desse espaço, escrito por AZEVEDO e et alli (1999). As autoras definem esse local assim, "o CTN foi criado como um espaço comercial, cuja clientela atende especialmente ao apelo de ser ali um lugar de encontro de nordestinos", Existem atualmente a radio Atual que funciona no CTN, além de outros programas, em outras rádios, como a Imprensa, Bandeirantes, Tropical, Capital ${ }^{6}$, voltadas para o público nordestino.

Existe uma série de trabalhos que contam a saga destes nordestinos em São Paulo, estivemos em contato com alguns deles como os artigos de ALBUQUERQUE (1990) e MENEZES (1990). Esse autores irão pesquisar a migração de nordestinos para São Paulo e Rio de Janeiro, na perspectiva de entender a sua inserção no mercado de trabalho. Sendo que o primeiro autor busca compreender a formação de estereótipos desses migrantes - Bahiano e Paraibanos, e como eles se identificam ou não, com a classe operária dessas cidades; a segunda autora que discute a corrente migratória de paraibanos para São Paulo e o seu retorno, faz uma investigação sobre a busca do migrante que almeja o trabalho por conta própria. Outras pesquisas mais recentes, continuam estudar esse fluxo migratório como: BISON (1995) que estudou a migração das empregadas domésticas do Vale do Jequitinhonha para São Paulo; BAPTISTA (1998) que estudou a rede de relações de nordestinos que moram na favela de Paraisópolis, em São Paulo; outra pesquisa em destaque é a de ESTRELA (1999), que estudou o fluxo de baianos que migraram para São Paulo e depois retornaram, os chamados "Sampauleiros". Para entender esse fluxo, examinam-se aspectos do cotidiano dessa migração bem como suas representações.

Esses estudos falam desse migrante que chega com pouca escolaridade ou nenhuma; que chega para, na maior parte das vezes, trabalhar na construção civil ou serviço doméstico; que vai morar em pensões, cortiços ou favelas, que enfrenta as dificuldades de andar na grande cidade e sente saudades.

“... a Capital paulista, aliás, transformou-se nesta segunda metade do século numa espécie de extensão do Nordeste, tanto que estatisticamente é a cidade

\footnotetext{
${ }^{5}$ Hoje o CTN apresenta uma diminuição na freqüência, segundo o depoimento de ex-comerciante, mas já chegou a reunir 40 mil pessoas, quando Frei Damião veio a São Paulo.

${ }^{6}$ Essa rádio possui um programa chamado "São Paulo - Capital - Nordeste" apresentado por Assis Ângelo.
} 
brasileira que maior número tem de nordestinos residentes ou em trânsito: cerca de 6 milhões, incluindo descendentes." (ÂNGELO,1995:69)

Procuraramos alguns dados, para dimensionarmos o universo de nordestinos na Grande São Paulo, infelizmente, os dados do censo 2000 ainda não estão publicados. Os dados, referentes a 1993, constam da última Pesquisa Nacional por Amostra de Domicílios (PNAD), divulgados pelo IBGE, apresentam 3.039.861 nordestinos, que representam 19\% da população da região metropolitana paulista. (F.S.P. 22.08.96). Consideramos nessa pesquisa o migrante nordestino, não apenas o recém chegado, diferente dos critérios determinados pelo IBGE na contagem populacional de 1996, que considera o migrante a pessoa não residente no município em $01.09 .91^{7}$. O nosso universo corresponde a toda a comunidade nordestina, considerando, até, os seus descendentes.

A pesquisa de Sandra Lencione (1991), mostra que há uma ampliação da metrópole, que segue em um raio de $150 \mathrm{Km}$ a partir do pólo da capital paulista. As unidades fabris, atraídas por terrenos baratos, favores fiscais, proximidade do mercado consumidor, vão se instalar nessa metrópole expandida, provocando uma dispersão industrial. A autora apoiada em Negri, mostra como o número de empregos segue essa reestruturação da industria: no período de 1980 a 1985, o interior criou cerca de 87,6 mil novos empregos industriais, enquanto a metrópole perdeu cerca de 144 mil postos de trabalho. Além da dispersão industrial, há o avanço tecnológico, que provoca o chamado desemprego estrutural. O migrante será mobilizado por essa reestruturação. Haja vista o crescimento acelerado da região de Campinas. O nordestino continua migrando para a Capital, mas em maior número desloca-se para a metrópole expandida. O crescimento da economia informal é constante e segue o avanço do desemprego. Assistimos diariamente ao aumento de vendedores ambulantes nos semáforos, nas ruas, calçadas, nas portas das casas com as mais diversas mercadorias.

Nesse contexto da migração de nordestinos para São Paulo, aparece a necessidade do migrante criar novas formas de inclusão na metrópole. Na procura dessa inclusão, um grupo de nordestinos vai criar e se inserir, em um segundo momento, em uma dessas formas de inclusão, o nosso objeto de estudo - o comércio de retalhos no bairro do Brás.

\footnotetext{
${ }^{7}$ O corte em 01.09.91 para efeito de coleta da informação, se dá em função da data de referência do censo demográfico de 1991, o que permitirá avaliar o movimento migratório neste intervalo, segundo os dados do IBGE, no site desta instituição.
} 


\subsection{Brás: bairro de migrantes, nascem as inserções...}

A atividade comercial do retalho, apareceu nas ruas do Brás, primeiramente nas mãos de um grupo de espanhóis que aproveitavam esse material para produzir estopas, ou no preenchimento de colchões; assim contam os Retalheiros:

“... Nóis foi os primeiro... O primeiro era uma filerinha, retalho com uma filerinha. Lá na Maria Joaquina, no número 72. O primeiro depósito existe até hoje, no número 40, no número 54. Aí veio, aí veio, aí veio o Otávio que é meu parente, por intermédio dele que eu entrei no ramo. O ponto dele foi ele. Foi o primeiro foi ele, diferente do espanhol, ele não vendia isso. O espanhol trabalhava, era diferente, ele era só pra moê, ele comprava à quilo e moía. Pra estopa. Agora ele morreu... Tem o maquinário... Ele deu trabalho... Tem otro espanhol que era... Era número 76 o depósito... Já faiz três ano já...” (Sr. Pajeú).

No sentido de entender melhor o surgimento e a localização dessa atividade, é interessante recuperar alguns estudos do Brás que o identificavam como um bairro de migrante. O bairro do Brás é um dos locais mais antigos da cidade de São Paulo; hoje compondo o centro expandido, está localizado a leste da cidade. Ver o mapa da localização do Brás na página seguinte.

“...encontra-se a dois quilômetros do centro da cidade, tem apenas cerca de dois quilômetros do centro da cidade, tem apenas cerca de cinco quilômetros quadrados, e inclui parte do Parque D. Pedro. Limita-se com os bairros da Moóca ao sul, Belenzinho e Catumbi a leste, Pari e Luz ao norte e a oeste com Santa Ifigênia e distrito da Sé.” (REALE, 1982: 5)

Foi ocupado inicialmente por chácaras que abasteciam São Paulo no século passado. Situado próximo da várzea do Rio Tamanduateí, sofria constantemente com o problema das enchentes, sendo uma das áreas mais insalubres e portanto, de menor custo para a moradia. 
Município de São Paulo

\section{Localização da área de estudo Brás}

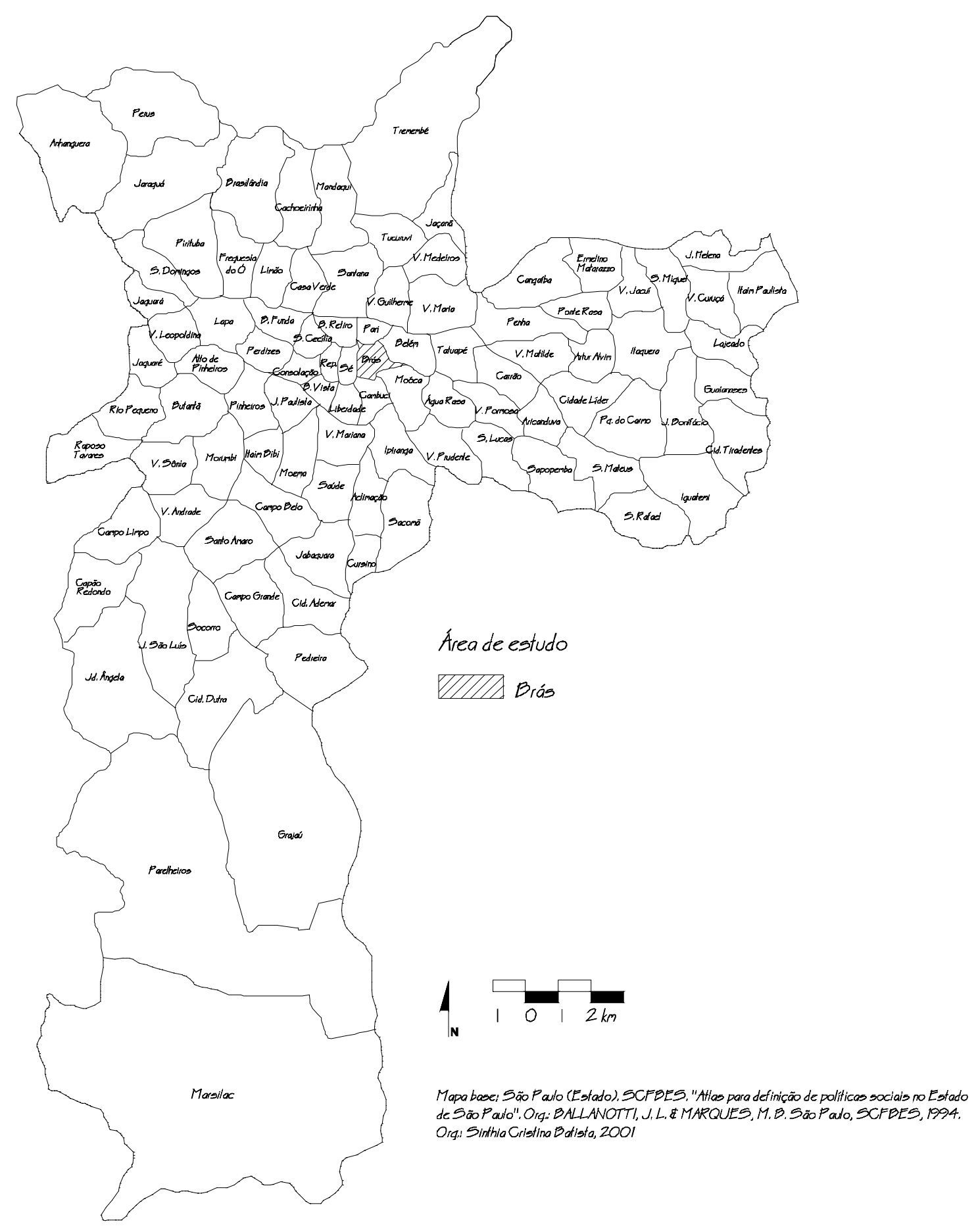


Então, essa área foi ocupada por uma população de baixa renda. Conhecido como um bairro operário ou bairro popular, por ser um bairro industrial, um dos primeiros a concentrar indústrias em São Paulo. Entre essa população encontram-se os imigrantes estrangeiros.

Dessa maneira, a caracterização do Brás como um bairro de imigrante nasce com alguns marcos fundamentais que seriam: a implantação da Hospedaria do Imigrante, juntamente com a linha ferroviária cruzando o bairro. "A inauguração da Estrada de Ferro do Norte, em 1877, constituiu um fato decisivo para o desenvolvimento do bairro.” (REALE, 1982: 13). Houve, também, a construção de uma nova estação da Inglesa, São Paulo Railway - SPR (depois, Santos-Jundiaí) localizada diante da Estação do Norte. Essa estrutura vinha para servir a economia cafeeira, que necessitava escoar seu produto e transportar a mão-de-obra para trabalhar nas suas lavouras. A Hospedaria do Imigrante, próxima das duas estações ferroviárias do Brás, foi inaugurada em 1887 e tinha capacidade para alojar, aproximadamente, 4000 pessoas. Foi construída pelo Presidente da Província, Antonio de Queiroz Telles - o Conde de Parnaíba - destinando para esse fim $100.000 \$ 000$ (cem mil contos de réis).

As ferrovias vão viabilizar tanto a economia cafeeira como também a indústria nascente, modificando o espaço da cidade, como mostra a análise de Caio Prado Jr.(1983):

"As ferrovias atraíam o povoamento que toma, assim, uma nova direção. Ao longo delas fixam-se as indústrias que procuram, como é natural, suas proximidades. E com a indústria vem o seu acompanhamento necessário que são os bairros operários. Assim se formam estes setores recentes, hoje densamente povoados, que envolvem as estradas de ferro e bordam, como uma auréola, as faces sul e leste do maciço paulistano: Ipiranga, Cambuci, Mooca, Brás, Pari, Luz, Bom Retiro, Barra Funda, Água Branca, Lapa.”(CAIO PRADO JR, 1983: 68)

No estudo de ANDRADE (1991) confirma-se a importância da indústria e da ferrovia como determinantes no processo de formação dos bairros do Brás, Moóca e Belenzinho. Nessa pesquisa, a autora faz uma recuperação dos serviços oferecidos (abastecimento, esgoto, gás etc..) para compreender a formação do bairro e a segregação urbana que essas áreas representam. Um dos elementos mais significativos desse trabalho é o entendimento do processo de desenvolvimento da indústria no Brás e mais 
especificamente da indústria têxtil. Nos reportamos a essa autora, para recuperar o processo histórico da indústria têxtil no Brás e as relações possíveis da presença do comércio de retalhos com ela e as confecções, no sentido de entender a presença do comércio de retalhos nas ruas desse bairro.

A primeira indústria de tecidos que aparece nas imediações do Brás, data de meados de 1870, como o relato mostra:

"A mais prestigiada entre as fábricas da década de 1870, nos documentos oficiais consultados, foi a fábrica a vapor de tecidos de Diogo Antônio de Barros, cujo funcionamento anunciado já em 1872, data de 1877. Ficava na rua que era a continuação da de São Bento, nas imediações da atual Rua 25 de março. Situava-se, portanto, na parte antiga da cidade, junto à Várzea do Carmo. O fundador era cidadão de Itu, de onde se transferiu para São Paulo com a família.” (ANDRADE, 1991: 99)

Outras indústrias já estavam instaladas no Brás e nas suas imediações, como, de cerveja no Marco Meia Légua ${ }^{8}$ ou de moagem de milho no Largo da Concórdia. Em 1889, foi instalada a Fábrica Sant'Anna, localizada entre a São Paulo Raiway -SPR e o Largo da Concórdia como mostrou a pesquisa de LANGENBUCH (1971), que estudou o crescimento e a estruturação da Grande São Paulo:

“No citado ano de 1890 já existia a importante fiação e tecelagem Anhaia, no Bom Retiro, e a tecelagem Sant'Anna, no Brás, que fabricava sacos de aniagem para produtos agrícolas, e que possuía desvio ferroviário para expedir a mercadoria ao interior." (p. $119-120)$

Essa informação, posteriormente é aprofundada na pesquisa de ANDRADE (1991), trazendo novos elementos que compõem o histórico da indústria têxtil em São Paulo como se pode observar na citação abaixo:

"A chegada da grande indústria nas terras além-Tamanduateí ocorre no período agora examinado. A pioneira é a Fábrica Sant'Anna, de Antonio Alvares Penteado, inaugurada em 1889. Neste ano dispunha de 50 teares e dez anos depois, de 600. Empregava, em 1898, 1300 operários e tinha uma

\footnotetext{
${ }^{8}$ Marco Meia-Légua: entre as ruas Bresser e Catumbi, junto à Av. Celso Garcia.
} 
capacidade instalada de $60.000 \mathrm{~m} /$ dia de tecidos para sacaria de café, cereais e enfardamento em geral." ( $p .114)$

Segundo a autora, em 1898, Antonio Alvares Penteado instalou uma tecelagem de lã com 100 teares, junto à Fábrica Sant' Anna. Nesse momento, surge uma outra fábrica de tecidos na Moóca, Regoli Crespi \& Cia.

“A Tecelagem ítalo- Brasileira de Sedas (Brás), fundada em 1907 por Crespi e Nicola Puglisi Carbone, era a maior fábrica de tecidos de seda do Estado. Os 514 operários trabalhavam 10 horas por dia na produção de fitas, cintos, cadarço, suspensórios, tecidos de seda, seda e linho, seda e lã. Em 10.000m² de área funcionavam as seções de tecelagem (180 teares), tinturaria, estamparia, passamanarias, oficina de preparação.” (p. 136)

A autora segue relatando o histórico dos primórdios da indústria têxtil no Brás, fazendo a seguinte ponderação:

"Essa superioridade do setor têxtil vai se manter ao longo das primeiras décadas do século $X X$, mas convivendo com um movimento no sentido de uma diversificação crescente da atividade produtiva.” (p. 128)

O crescimento da indústria têxtil é surpreendente, outras fábricas, tanto de grande porte como pequeno, se instalaram no Brás e bairros adjacentes como: Tecelagem Mariângela (1904) no Brás, Tecelagem Belenzinho (1911) localizada no Belenzinho, a Fábrica Maria Zélia (1912), construída no Belenzinho, Cia Paulista de Tecidos de Algodão (1927) na Moóca, além dessas encontramos São Paulo Alpargatas Company, no Brás; fábrica Santo Antônio no Belenzinho.

"Indiscutível parece ser o fato que as maiores fábricas de tecidos da cidade ficavam no Brás e na Moóca, concentrando cerca de $70 \%$ da força de trabalho desse ramo. A produção maior dessas fábricas continuava sendo de aniagem e algodão.” (p. 134)

Como sintetiza Pasquale Petrone (1955): “De início, ampliou-se a área do Belenzinho e da Moóca, graças aos três fatores conjugados: o desenvolvimento industrial, as correntes imigratórias e a presença da via-férrea.” (p. 140), aos quais acrescentamos o bairro do Brás. 
Outra empresa têxtil importante é a Tecelagem Mariângela, de 1904, empresa ligada ao Grupo Matarazzo. A primeira fábrica, do grupo, nasce no Brás, em 1900, na rua Monsenhor de Andrade, junto à SPR, nas proximidades do Largo da Concórdia: era o Moinho Matarazzo. A oficina para fabrico de sacos deu origem à Tecelagem Mariângela, em 1904. Desde o início tinha seções de fiação, tecelagem de algodão e cascamifício (produção de fibras para cobertor, conforme indicações encontradas). Em 1910 foram acrescentadas as seções de tinturaria e estamparia. Em 1935 a Matarazzo adquire o conjunto de estabelecimentos da antiga Tecelagem Ítalo- Brasileira de Sedas. E em 1972, a sede social da empresa do Grupo Matarazzo foi instalada no Brás em um dos prédios da antiga Tecelagem Ítalo-Brasileira de Sedas, localizado nas ruas Joli e Sampson.

Essa transferência da sede IRFM, do centro para o bairro do Brás, nesse período foi vista como um indicador da ruína do "Império Matarazzo", em função da deterioração do bairro. "E, por ironia, foi ocupar um imóvel de uma fábrica que sequer foi criada pelo grupo, que a comprou já plenamente consolidada. Nenhum dos demais imóveis industriais do Grupo Matarazzo no Brás, Moóca e Belenzinho ( e, quem sabe, na cidade de São Paulo) tem a imponência daquele que abrigou a Tecelagem ÍtaloBrasileira de Sedas." (ANDRADE, 1991: 188 )

Na pesquisa de ANDRADE (1991), aparece, no depoimento do representante da diretoria da IRFM, a visão do entorno da sede estar sofrendo em processo de deterioração associado ao comércio de retalhos, identificado pelo depoente como 'comércio de trapos'. E continua a autora:

"O diretor está se referindo à venda de retalhos provenientes das confecções (setor industrial dominante no Brás hoje), em lojas de aspecto improvisado. Este comércio estaria, segundo o entrevistado, em poder de nordestinos que tiveram alguma ascensão econômica e puderam estabelecer-se por conta própria.

O que deve incomodar mais deve ser justamente essa vizinhança como os nordestinos, na fala da maioria dos entrevistados, vistos como responsáveis pela degradação do Brás, Moóca e Belenzinho. No século passado os imigrantes estrangeiros ; hoje os nordestinos.” (p. 188) 
Sobre a deterioração do Brás, discutiremos mais adiante. No momento é importante observar como esses elementos confirmam a idéia de que a atividade comercial de retalhos e resíduos nasceu nos interstícios das fábricas de tecidos e, principalmente, das confecções do Brás. Entretanto, essas indústrias têxteis foram desaparecendo ao longo do tempo. Ao identificarmos a localização do núcleo, ou seja, a concentração do comércio de retalhos que estamos estudando, constatamos primeiro que essas unidades estão nas ruas que levam os nomes de 'antigos 'fabricantes' $e$ artesãos dos anos de 1870 e início dos anos de 1880. - Bresser e João Boemer, proprietários, respectivamente, de um moinho e de uma cervejaria. Outro elemento significativo é a proximidades dessas unidades comerciais de retalho em torno das antigas fábricas de tecidos. Como foi observado no trabalho de campo, as lojas de retalhos e resíduos estão no entorno do escritório central do Grupo Matarazzo, confirmada na pesquisa de ANDRADE.

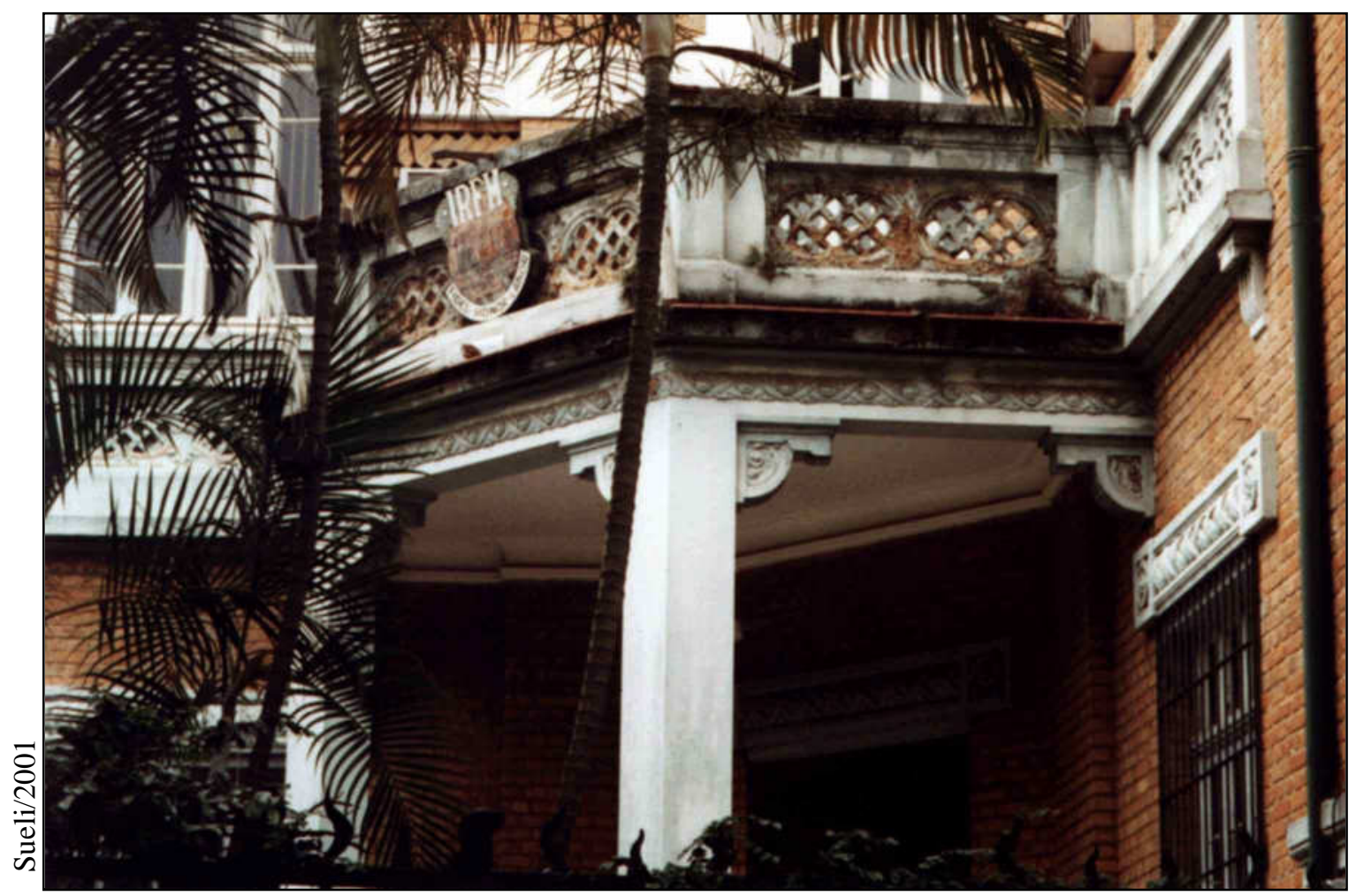

Foto 11: Escritório central do grupo Matarazzo instalado na rua Joly. Veja o emblema indicando "Indústrias Reunidas da Francisco Matarazzo". 
As indústrias tradicionais de tecidos recuaram, no entanto, havia outro tipo de indústria em plena expansão que é a indústria de confecções. Essa alimentará a continuidade desse comércio, nas ruas do Brás. Estudaremos o desenvolvimento da indústria de confecção mais adiante.

ANDRADE (1991) faz a seguinte leitura sobre o recuo das indústrias do Brás. "Ele está associado à obsolescência tecnológica, eliminando as empresas que não se modernizaram. É falso associar a evolução recente da indústria têxtil à desnacionalização do setor.” ... “O capital local continuava predominando.” (p. 210) Essa conclusão da autora se baseia no estudo de Queiroz e Evans sobre as relações entre o capital nacional e o estrangeiro na indústria têxtil. Ela complementa com os exemplos das empresas: Hering, Paramont, Indústrias Reunidas Vicunha. O processo de desindustrialização, que ocorrerá nas áreas mais antigas da cidade, estudado por RAMOS (1998), “...sugere, portanto, que determinada área industrial deixe progressivamente de ser caracterizada economicamente por sua atividade industrial, havendo, na maior parte dos casos um paralelo avanço do setor terciário.” (p. 10), como observamos no Brás.

Retomando sobre a formação do bairro do Brás, é importante lembrar a presença do imigrante europeu, principalmente o italiano, e depois seguido do espanhol e o português, sobretudo, operários.

Alguns desses imigrantes, que vieram com capital, se destacaram na economia brasileira, como a história do Matarazzo, que possuiu 365 empresas no seu império e, também, a família Crespi. Oficinas de fundo de quintal que prosperaram formaram indústrias de grande porte. Porém, a grande massa de imigrantes e seus descendentes vieram constituir a força de trabalho para a indústria brasileira nascente. Assim, vemos como o processo de industrialização e o fluxo migratório estão intrincados.

Algumas fábricas nasceram como oficinas de "fundo de quintal" criadas por filhos de imigrantes operários, entre elas: Têxteis Ribeiro e Paulo Andrighetti que foram estudadas por ANDRADE (1991). Outra pesquisa que destaca a presença italiana é de EBE REALE que faz uma lista com cerca de 15 indústrias e oficinas, cuja fundação varia desde 1878 até 1908 , pertencentes a italianos. O número é muito maior, sendo que alguns nomes importantes não fazem parte desta lista.

Em relação aos operários europeus na indústrias, temos os seguintes dados para 1911 - "Em vinte e três fábricas trabalhavam 10.204 operários. Os estrangeiros 
somavam 7.500 , dos quais $80 \%$ italianos, $11 \%$ portugueses, $5 \%$ espanhóis" 9 . Portanto, cerca de $90 \%$ de estrangeiros em relação aos nacionais, nas indústrias paulistas.

A presença italiana merece destaque no entendimento da formação do bairro do Brás, composta pela grande maioria de operários da indústria nascente. Assim orientamos nossa pesquisa, para podermos entender a sua posterior transformação. Busquemos mais elementos da migração italiana no Brás, para entender o que era o Brás e a sua transformação.

\subsubsection{A grande imigração}

Com o propósito de entendermos as transformações, em curso no Brás, sentimos a necessidade de fazer um recuo no tempo e lidar com a chegada e instalação de migrantes estrangeiros neste espaço. A presença do migrante estrangeiro no Brás está inserido em um processo mais amplo, o da substituição da mão-de-obra escrava pela mão-de-obra livre. A migração fez parte de uma política para abastecer, inicialmente, a mão-de-obra das lavouras cafeeiras. Esse período é denominado de "A Grande Imigração"; ocorre a partir de 1880 até a década de 1930, aproximadamente.

Para garantir a reserva de mão-de-obra, foram tentadas várias formas de estímulo à migração de estrangeiros como parcerias, pequenos proprietários em núcleos colônias oficiais e por fim a migração subsidiada. E dessa maneira promover a migração de estrangeiros

O Governo provincial de São Paulo organizou um sistema de colônias oficiais, loteamentos que foram vendidos a preços módicos. Ao adquirir um lote, o imigrante realizava o seu sonho de ser proprietário. Entre 1876 e 1890, foram criados 15 núcleos coloniais, no estado, segundo MARTINS (1973). Uma grande parte desses núcleos estava localizada em áreas de pouca fertilidade, principalmente no entorno da cidade de São Paulo, como o caso do núcleo de São Caetano pesquisado por José de Souza Martins (1973).

A última forma de promoção foi a migração subvencionada pelo Estado, pois liberava os fazendeiros de alguns gastos e os migrantes de algumas dívidas. Eles vinham para trabalhar em um regime de colonato, isto é, determinava-se uma quantia em

9 “Condições de Trabalho na Indústria Têxtil do Estado de São Paulo”,p.35 in ANDRADE (1991). 
dinheiro a ser paga pelo trato de determinado número de pés de café. Além disso, tinham a possibilidade de cultivar a sua roça de subsistência, o que desobrigava o fazendeiro de custos de reprodução da força de trabalho. O fluxo migratório era intenso, pois o Estado subvencionava os custos de transporte e alojamento inicial dos migrantes. Os migrantes que chegavam ao Brasil para trabalhar na lavoura do café, vinham com a promessa do Estado que aqui conseguiriam, em pouco tempo, a sua própria terra para cultivar, pois a quantidade de terras que o país possuía facilitaria tal processo. Porém, ao contrário a terra fértil começa a ser objeto de especulação e sofre rápida valorização. A lei de terras de 1850, servia para dificultar o acesso à propriedade, pois a compra era para quem tinha um certo acúmulo de capital, excluindo boa parte dos migrantes. Esses, levavam anos trabalhando com a esperança de ter algum pecúlio, como lemos na obra de MARTINS (1979), O Cativeiro da Terra.

O contigente, crescente, de migrantes destinados à lavoura, descia na estação do Brás, em função da Hospedaria, e por vezes, continuava na cidade. Essa migração subsidiada, custeou, também, o deslocamento em direção à cidades. As duas estações ferroviárias recebiam os imigrantes do Porto de Santos e do Porto do Rio de Janeiro, além dos migrantes originários do interior do Estado e os egressos da lavoura. MARTINS (1973) relaciona esse fluxo à não absorção do excesso de mão-de-obra pela agricultura. O imigrante tanto aspira a ser proprietário rural, como também, a ser autônomo na cidade. Os imigrantes "procuravam na cidade um meio de ascensão econômica e social”. (ANDRADE : 1991,72)

Assim, tanto as estações ferroviárias como a Hospedaria foram fundamentais para a formação do bairro. Vejamos os dados que MARTIN apresenta:

“Entre 1887 e 1930 deveriam entrar na Província de São Paulo, nada menos que 2 milhões e 500 mil imigrantes, incluindo-se aqui cerca de 280 mil nacionais de outras províncias e 85 mil japoneses. A maioria deles contudo era composta por italianos. De 1887 a 1915 entraram na província cerca de 800 mil italianos, vindo a seguir em importância os espanhóis com 300 mil e os portugueses com 260 mil." (MARTIN: 1984, 63)

A imigração estrangeira será a maior responsável pelo crescimento da cidade de São Paulo, no final do século XIX. Sendo que o Brás apresentava os maiores índices de crescimento populacional, segundo as pesquisas de ANDRADE (1991) - “... $a$ concentração de imigrantes corresponde à zona de urbanização compacta a leste da 
Várzea do Carmo, que inclui os bairros do Brás, Pari e Moóca.”. Os italianos, na maioria, se instalavam muitas vezes em condições insalubres, nesses bairros industriais.

A Hospedaria de Imigrantes foi um pólo aglutinador de migrantes, que se estabelecem aos seus arredores. Enfim, o grande número de migrantes na cidade de São Paulo relaciona-se à localização da Hospedaria na Capital. Conforme ANDRADE (1991),

“A localização da hospedaria em São Paulo teria então estimulado não só a fixação direta de imigrantes na cidade, como pode ter estimulado a opção pela capital em detrimento de outras cidades do Estado, por imigrantes que deixavam as fazendas em busca de outras alternativas, nos momentos de crise da cafeicultura, ou depois de terem amealhado algum recurso para se estabelecerem.” (p. 88)

Ocorreram muitos debates e conflitos entre a elite, sobre essa população aglutinada em torno da Hospedaria. Era a xenofobia de parte da elite que se fazia presente. A antiga Hospedaria do Imigrante, denominada atualmente de Memorial do Imigrante, projetada, inicialmente, nos Campos Elíseos. Seu terreno já havia sido comprado, devido à existência de duas importantes estações ferroviárias: a da SPR e a da Sorocabana em que a estação da Luz serviria como ponto de parada para o desembarque da mão de obra imigrante. Porém, ela acabou sendo construída no Brás como uma "estratégia da elite de segregar os imigrantes, dos bairros ditos burgueses." (ANDRADE:1994, 99). Assim, o caráter segregacionista é explícito, haja vista os documentos consultados por ANDRADE. Como a declaração de um Presidente da Província: “...não é lugar próprio para um alojamento de imigrantes o bairro (da Luz) que mais se presta a ser aformoseado, e que vai merecendo a preferência da população abastada para aí construir prédios vastos e elegantes" ${ }^{\prime 10}$. Continua adiante justificando a localização do Brás:

“É possível consultar todas as exigências do serviço mediante à colocação do edifício em terrenos do Brás, a qual permitirá, o que é vantagem considerável, que os imigrantes vindos quer por uma quer por outra estrada (Estradas de Ferro Santos- Jundiaí e do Norte), desembarquem com suas bagagens dentro

\footnotetext{
${ }^{10}$ Relatório do Presidente da Província João Alfredo C. de Oliveira à Assembléia Legislativa Provincial 1886, São Paulo, Typografia de Jorge Secker \& Cia in Andrade (1994).
} 
do estabelecimento, e tomem na estação que ali tem a estrada Inglesa os trens que demandam o oeste da província, para onde em geral se encaminham.” ( $p$. $74-76)$

Dessa forma, nos arredores da hospedaria, forma-se um grande número de habitações populares, ocupadas pelos migrantes e seus descendentes. Eles retornavam das lavouras, ou por causa da crise da cafeicultura, ou fugindo das péssimas condições de trabalho nas fazendas de café. Aqueles que vinham com passagem paga pelo governo e optavam por ficar na cidade, na verdade burlavam as regras do Serviço de Imigração. Eles teriam que descer na Hospedaria do Brás para acertar o contrato de trabalho junto aos fazendeiros ou seus representantes. No ano de 1894 ou 1895, dos 74.975 imigrantes chegados, 37.641 não foram para as lavouras e 5.800 não deram entrada na Hospedaria. $\mathrm{O}$ fato de eles escolherem a cidade para se estabelecer estava relacionado ao mercado de trabalho urbano, que aumentava em função da nascente industrialização. (ANDRADE, 1991)

A quantidade de imigrantes na cidade preocupava a elite. O preconceito e a discriminação se agravava com o surto de cólera que se alastrou entre os imigrantes recém chegados, cogitando-se a remoção da hospedaria que, para os deputados punha em risco a população da cidade. $O$ contraste da paisagem materializava esse segregacionismo, onde de um lado, as elites buscavam "embelezar" a sua parte da cidade com parques e bulevares e no outro lado do rio ficavam os lixões, ruas enlameadas, sem água e esgotos. (ANDRADE, 1991).

Para MARTIN (1984) a condição de migrante levava esses grupos a constituírem verdadeiros "guetos" onde, encurralados culturalmente, tinham dificuldade de entender o seu bairro fazendo parte da totalidade da cidade e de sua classe no seu país. Daí não haver lutas urbanas, e as lutas sindicais se encerravam nas questões monoclassistas, enquanto a "consciência urbana" era pluriclassista. Os italianos traziam o Movimento Anarquista e disseminavam as suas idéias no movimento operário e pelas ruas do Brás. 


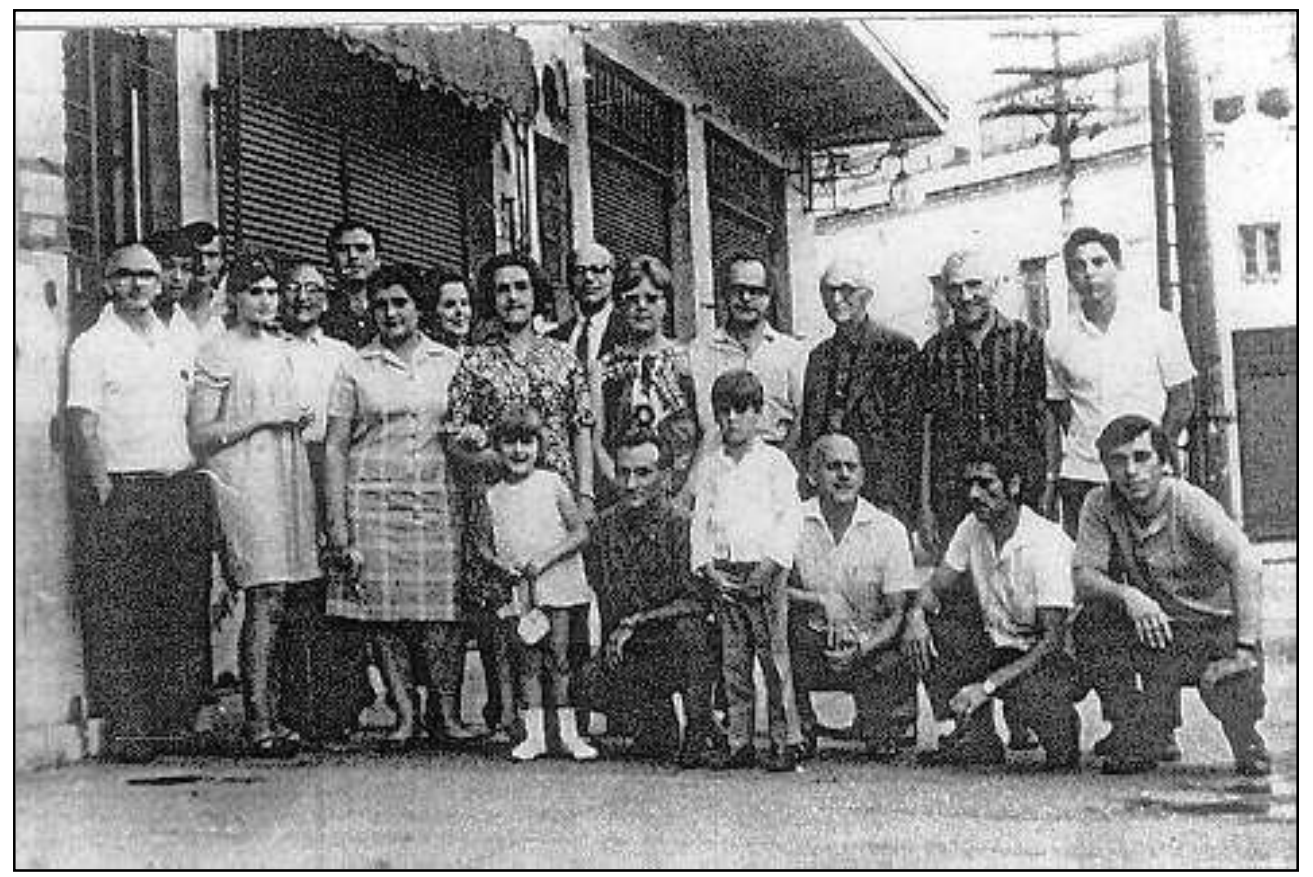

Foto 12: Encontro Libertário em 1968, na sede, rua Rubino de Oliveira.

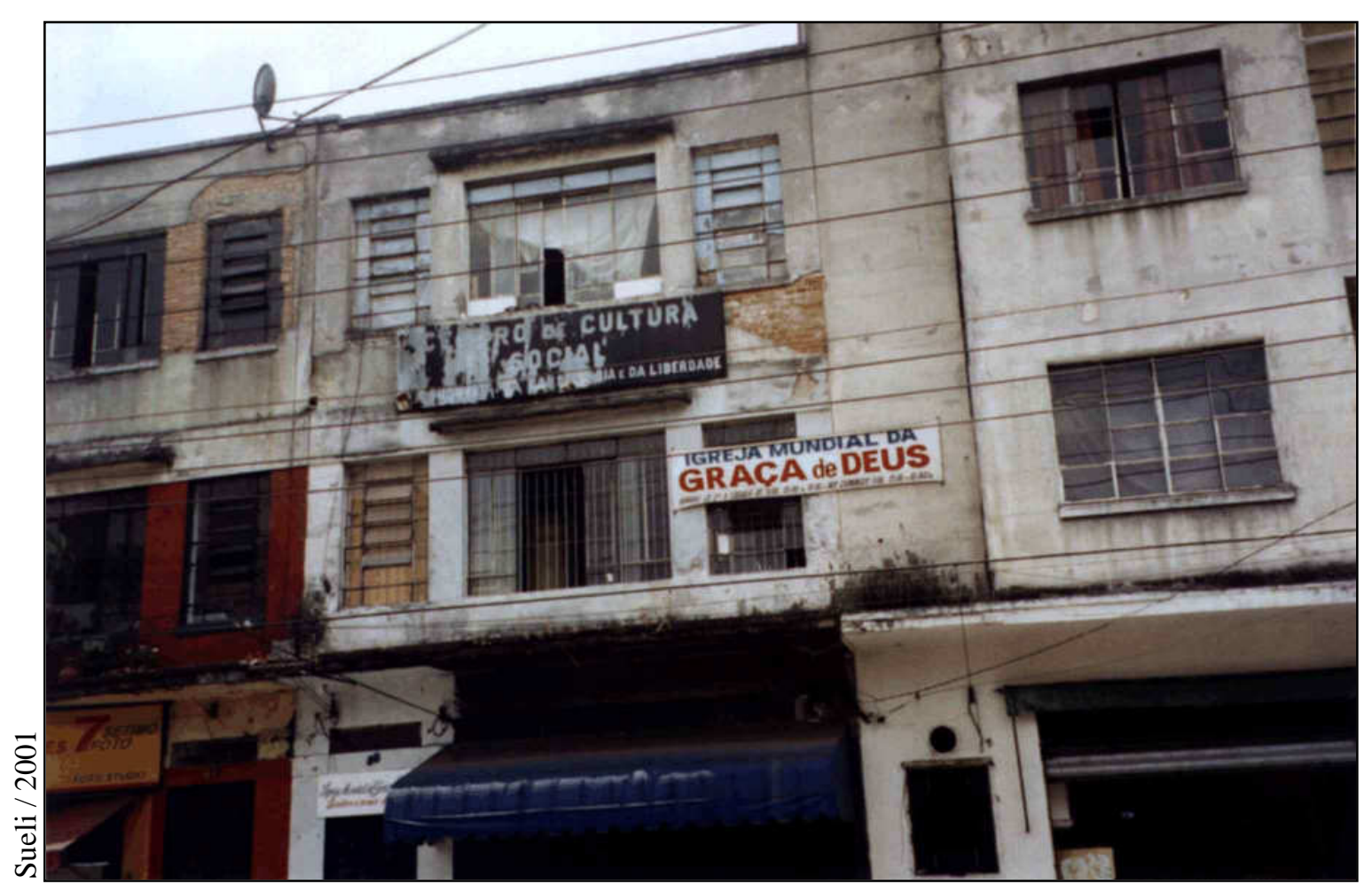

Foto 13: Antiga sede do Movimento Anarquista na Rua Rubino de Oliveira transformada em um templo religioso. 


\subsubsection{O bairro italiano}

Até os dias de hoje o Brás é chamado, por alguns, de bairro italiano. Quando andamos por suas ruas reconhecemos algumas construções que documentam a época em que a população imigrante italiana representava uma grande parcela da população de São Paulo. Identificamos as pizzarias, as vilas operárias ou então escutamos algum idoso falando em italiano. Tanto o trabalho de Ebe REALE (1982), como o de MARTIN (1984), e o de ANDRADE (1991), registram esses elementos que caracterizam o lugar.

A formação do bairro ocorre em função da Grande Imigração promovida pelo governo Brasileiro.

"A análise de documentos sobre a Hospedaria de Imigrantes e de dados sobre a nascente indústria paulistana, revelou o impacto da política de imigração sobre a cidade de São Paulo, impacto esse que, ao que tudo indica, superou as previsões de seus formuladores, ou pelo menos daquela parcela comprometida com os interesses exclusivistas da cafeicultura." (ANDRADE: 1994, 97).

Temos que fazer a seguinte observação, apesar de o Brás ter sido conhecido como um "bairro italiano" e dos italianos terem tido uma maior participação no total de emigrantes europeus, há que se considerar a presença significativa dos espanhóis, que se concentravam na rua Carneiro Leão. A presença dos espanhóis no Brás, nos auxilia a entender os primórdios do comércio de retalho iniciado por esses imigrantes como o aproveitamento do refugo da indústria têxtil. Eles começaram a recolher os retalhos e resíduos das tecelagens e transformá-los em estopas. Usava-se uma máquina chamada "tesourinha" e a "máquina do diabo", pois ocasionavam muitos acidentes de trabalho, e muitos operários perdiam os dedos que eram picotados na hora de colocarem os retalhos na máquina. Uma boa parte dessas estopas iam para o porto de Santos, para a limpeza dos navios, para os estofamentos, indústria de móveis, e para as mecânicas. Essa atividade aparece nas ruas do Brás, em meio às residências dos operários. Os depoimentos dos atuais retalheiros nos falam desses espanhóis. Esses depoimentos vão ao encontro das pesquisas realizadas sobre os migrantes espanhóis. De acordo com Jacob Penteado: 
“Os Ibéricos, porém, não se adaptaram muito aos trabalhos das fábricas nem da lavoura. Preferiam trabalhar por conta própria, exercendo outros misteres, os mais variados, tais como saqueiros, cigarreiros, funileiros, remendões, sorveteiros, vendedores de brinquedos, de frutas, além de compradores e revendedores de garrafas, chumbo, metal e cobre. E com isso muitos deles fizeram fortuna. Quem nunca ouviu falar do rei do ferro velho? Sempre houve um monarca dessa espécie no Brás e ainda os há.” (PENTEADO, Jacob, 1962:57).

Acrescentamos a essas observações acima a atividade de compra de retalhos. Talvez usa-se a mesma lógica do rei do ferro velho na busca de uma estratégia de inserção social. Será que existiu o rei do retalho? Desses espanhóis, alguns retornaram para a Espanha, outros já faleceram. De outros temos notícias que moram no Pari e em outros bairros da Zona Leste. Sabe-se que resta uma fabrica de moagem dos resíduos no Brás, que acompanhou o recuo dos depósitos de resíduos nas ruas do Brás. Essa fabrica é controlada pelo filho do espanhol. No próximo capítulo retomamos a origem desse comércio. Por hora, tentaremos entender o que era o Brás naquele período.

Sobre o universo de imigrantes na cidade, se comparados com a evolução da população, temos o seguinte: a população da Província de 1,04 milhões (1886) passa para 2,28 milhões (1900) ou seja ela duplica. Na capital, de 65 mil habitantes (1890) passa para 240 mil em 1900 (MARTIN,1984:63). Enfim, o fluxo migratório atraído pela economia cafeeira tem um peso significativo para a dinâmica populacional e principalmente no desenvolvimento da cidade de São Paulo, e mais precisamente para o bairro do Brás. Outros bairros se formaram no mesmo processo como a Moóca, Belenzinho, Bom Retiro, Barra Funda, Água Branca, Bela Vista e Cambuci.

Sobre o crescimento urbano VILLAÇA (1978) afirma:

"Há que se considerar ainda que a partir da última década do século passado, o crescimento de São Paulo passa a ser crescente constituído pelas camadas populares - que são adensadoras - e cujos bairros (Brás, Bom Retiro, Barra Funda etc.) começam a se expandir”.(p.34)

A formação da unidade do bairro do Brás, que também concentra comércio, serviços, atividades culturais e diversas relações sociais é destacada por ANDRADE em um artigo como 
“...um núcleo complexo de vida social se constitui polarizado pelo Brás, a designação de "outra cidade" traduzindo a complexidade da realidade social que caracterizou esse conjunto de bairros operários até meados do século atual”. ( ANDRADE,1994:101)

Vejamos um pouco, o que seria essa vida social de bairro no Brás, nesse período. Os napolitanos se concentravam na rua Caetano Pinto e eram a maioria, haviam, também, Calabreses e Sicilianos. E as diferenças regionais e culturais se faziam presentes no cotidiano dessas ruas, veja:

“O Brás foi ficando Napolitano mesmo sem o Vesúvio, foi ficando Siciliano, mesmo longe do Étna. A Itália era aqui, e os vulcões não fazem falta” (Neide Duarte: 1997).

O imaginário de uma Itália tinha sido recriado nas ruas, com suas histórias do além-mar, sua cultura e seus costumes. Os imigrantes moravam nos cortiços, nas vilas operárias e nos "quintões", tinham sempre uma arquitetura que gerava intimidade. As portas e as janelas, próximas da rua e sempre abertas, tinham que dividir muitas vezes os tanques, os varais e os banheiros. Enfim, havia uma vida em comum entre as famílias. As relações de vizinhança e solidariedade eram muito fortes e isso aparecia mais explicitamente nas festas das vilas - “Aqui em São João, nós fazia festa, aqui dançava quadrilha, era uma maravilha o Brás". (Angelo Agnello - atual morador do Brás $)^{11}$

“Aqui atrás,... Rua do Senhor Anacleto tinha vilas, morava os italiano, então ficava tudo sentado, né. Sete, oito horas da noite. Naquele tempo não tinha televisão, novelas, então ficava fumando cachimbos, a gente passava, todo mundo conhecia todo mundo.

- Eh! Osvaldo. Bom Diorno, Como vai o papai?

- Eh! Arcanjo, bom Diorno.

- Tina, Como tai belle!

- Eh !...jogou com Palestra.’ E era assim”. (Osvaldo Matiello)

${ }^{11}$ Os depoimentos de Angelo Agnello, Osvaldo Matiello, Dina Enriquez, Jaime Cuberos, José Duarte de Oliveira foram retirados do documentário da TV Cultura "Brás: Memória em Pedaços", realizados pelas jornalistas Neide Duarte e Maria Cristina Polli. 


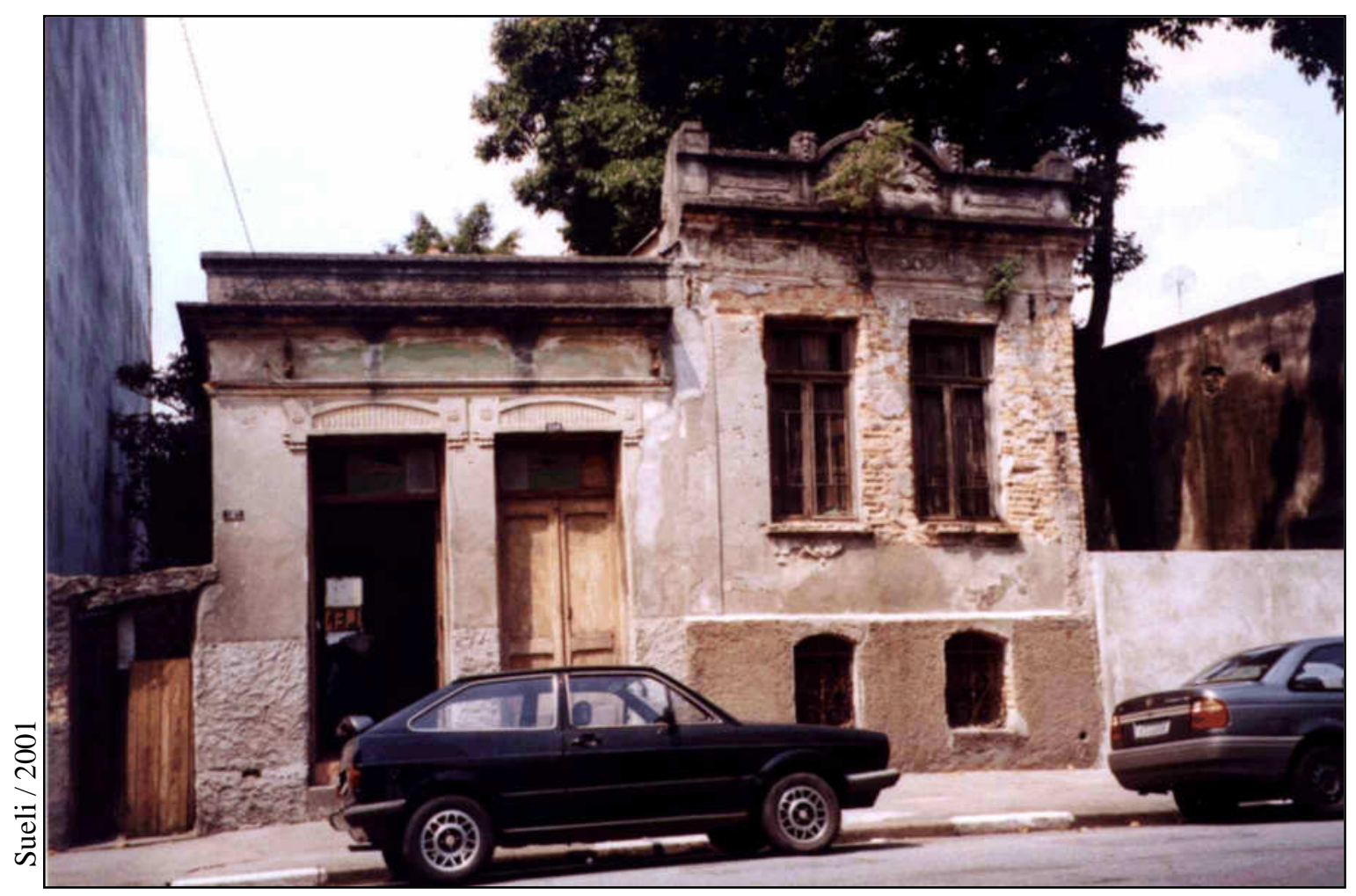

Foto 14: Residência onde funciona a barbearia do Sr. Valter, há cinquenta anos. Essa casa pertenceu à sua avó e se localiza na rua Rio Bonito.

Se por um lado, essas relações de vizinhança cultivavam a solidariedade, eram também, uma forma de controle social e moral daquela comunidade:

“A gente ia namorar. Porque todo o bairro concentrava lá. Uma numa árvore, outra na outra, e quando você ia dar uns amassinhos a mais, o guarda vinha e falava 'Circulando! Senão vou chamar o papai! A gente tinha medo. A gente namorava tudo escondido, né." (Dina Erriquez, Brás)

Assim, dessa maneira, o Brás foi se constituindo em uma unidade, e começa a se impor. Havia uma contradição entre "o 'canto' tipicamente italiano, $e$ a 'ironia' própria e necessária dos de 'de baixo' que caçoam da afetação do modo de falar das elites.” (MARTIN: 1984, 167). Aos poucos, os italianos que adquiriam um capital maior iam buscar os bairros mais nobres, com maior conforto.

"A população mais humilde procurou bairros mais afastados, em busca de aluguéis mais acessíveis. Outros, de maior poder aquisitivo, mudaram -se para casas ajardinadas e dotadas de mais conforto, nos bairros do Pari e Alto da Moóca ou buscaram, já de anel de doutor no dedo, maior "status" nas 
moradias luxuosas da Zona Sul. Aos poucos, com a morte dos velhos peninsulares e a partida de seus descendentes, o Brás foi perdendo seu caráter tipicamente italiano.” (REALE, 1982: 58)

Como na obra de BERMAN (1987):

"Pois o Bronx de minha juventude estava possuído, inspirado pelo grande sonho moderno da mobilidade. Viver bem significa ascender socialmente $e$ isso, por sua vez, significava mudar-se fisicamente;...” (p. 310).

Um antigo menino do Bronx , muito tempo depois, diz a BERMAN, quando refere-se ao seu bairro da infância:

“'Você sabe qual a moral do Bronx? 'Saia daqui, idiota, arranque-se.” (p. 311)

Outros, que não suportavam o preço dos aluguéis, buscavam os novos loteamentos que apareciam. O Brás começou a se desestruturar e a unidade a se fragmentar em função da metropolização.

Existiam alguns lugares simbólicos que foram demolidos, na política do arrasa quarteirão. O cinema Colombo sofreu um incêndio, e hoje está sendo demolido, outros cinemas viraram estacionamento, shoppings e bancos. Lembra o velho anarquista:

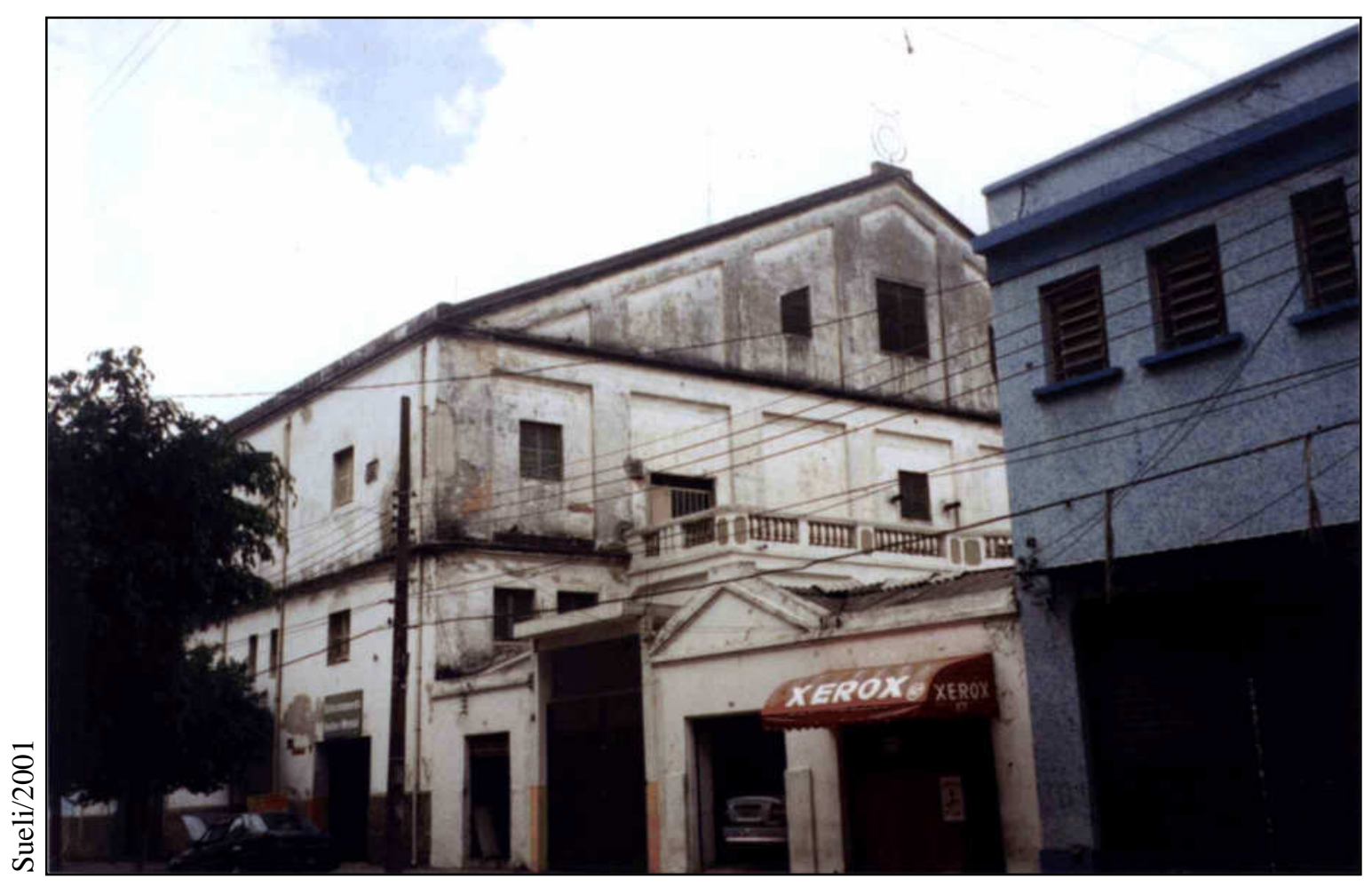

Foto 15: O cineteatro Politheano foi transformado em um estacionamento 
“...aqui se fez também muito comício, reuniões políticas, claro; comemorar o $1^{o}$ de maio - 'A melhor expressão da ordem é a Anarquia'. Essa era uma das práticas que eu sempre fazia" (Jaime Cuberos);

“É uma pena ver isso virar estacionamento.” (José Duarte de Oliveira)

Como uma cópia do filme "Cinema Paradiso", o simbólico fica armazenado na memória, fazendo parte de um bairro virtual.

“Charles Chaplin não tinha voz...

Greta Garbo não tinha voz...

-E agora é como se aquele tempo se instalasse de novo no Brás

- Adeus Teatro Colombo, adeus Brás Politheano

- Adeus Babilônia, Adeus Piratininga

O silêncio voltou nos cinemas do Brás.”

(Neide Duarte)

Essas modificações e características do Brás também foram constatadas nesses estudos, que apontam os poucos elementos da cultura italiana a permanecerem no bairro, entre tantas mudanças:

"Nos cortiços, os gritos dos napolitanos foram substituídos pelo falar cantado dos baianos, em vez de serenatas e tarantelas há o baião e os forrós, ao lado de salames e provolones encontramos nos armazéns carne seca e farinha, e as bancas de jornal vendem literatura de cordel em lugar do "Fanfulla". Da presença italiana no bairro, pouco resta: somente algumas cantinas e as festas de Nossa Senhora de Casaluce e de São Vito.” (REALE, 1982: 58) 


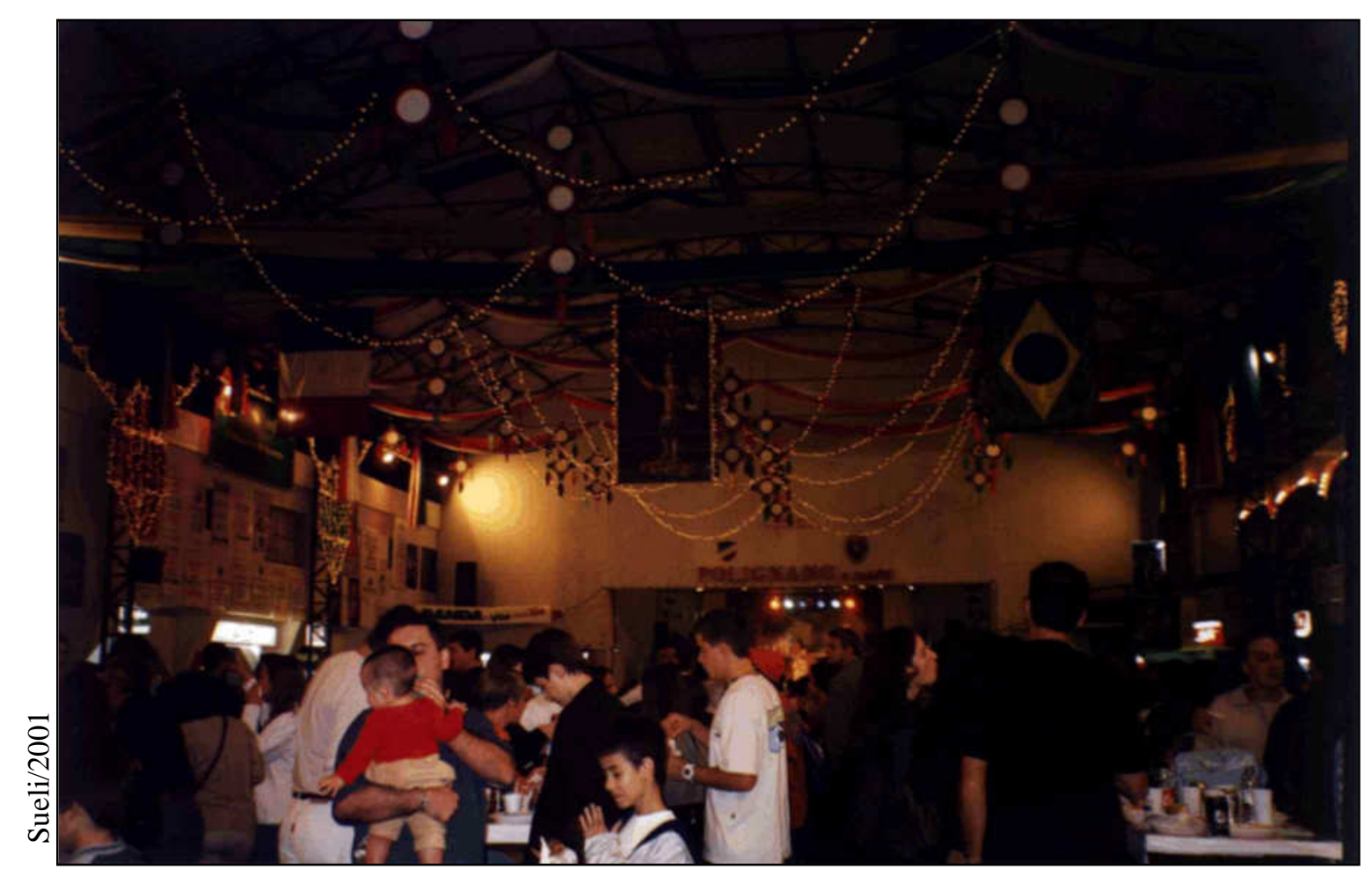

Foto 16: A Festa de São Vito ocorre no mês de junho. Uma festa típica italiana. 


\subsubsection{Bairro nordestino ou "nó" do Brás? A fragmentação}

O Estado deixa de promover a migração externa e passa a estimular a estimular a migração interna. Encontramos em VAINER (2000) alguns elementos que reorientam essas mudanças. A concepção de Kystos Éthnicos que ameaçam a nacionalidade e a integridade territorial do país se fazem presentes, então ocorre a preocupação com o grande contingente de migrantes externos, como discute o autor acima:

"O imigrante, cujo amor ao trabalho, disciplina e eugenia havia sido exaltados como salvação da pátria, aparecia, agora, à luz da problemática assimilacionista, como grande ameaça a esta mesma pátria. Desconhecedor de nossos costumes, fiel a outros Estados, o imigrante era ainda mais perigoso quando adepto do anarquismo ou socialismo, ideologias dissolventes completamente estranhas à índole pacífica e cordata de nosso povo.” (p.19)

Algumas medidas restritivas à imigração foram implementadas pelo Estado, desestimulando a migração externa. A partir dos anos 30, principalmente na Segunda Guerra Mundial, deixa-se de promover esse fluxo. Enquanto isso, havia uma crise agrária, ou melhor, uma pressão exercida por um grande contingente populacional, cada vez maior, sobre a estrutura fundiária. O estímulo à migração interna aparece, assim, como uma forma de controle social e político.

“Nos corredores da Hospedaria do Imigrante, em São Paulo não se ouvem mais o italianos e o espanhol, agora substituídos pelos sotaques nordestino e mineiro... afinal de contas, São Paulo, que não pode parar, já havia descoberto desde os anos 40 que os nordestinos e mineiros, os trabalhadores nacionais podem ser disciplinados para o trabalho..." (VAINER, 2000: 24)

O desenvolvimento industrial brasileiro impulsionou o acelerado crescimento urbano, próprio da metropolização. A cidade passa então a concentrar o fluxo migratório interno de trabalhadores expulsos do campo. Estes, por sua vez, recriaram os espaços da cidade de São Paulo, destacando o Bairro do Brás. Nesse contexto, “até 1940 haviam entrado cerca de 1,2 milhões de migrantes nacionais, principalmente nordestinos, no estado de São Paulo. Daí até 1970 chegariam mais de 4,5 milhões, sendo que 1,5 habitam o município." (MARTIN, 1984: 170) Nesse quadro poderemos 
entender a presença dos nordestinos, mobilizados pelo capital, que se estabelecem no Brás, e o tem como referência.

Os nordestinos elegeram o Brás como uma das áreas de concentração. Os antigos casarões passaram por subdivisões servindo de abrigo para os migrantes que ali residiam e ainda residem, em condições totalmente insalubres: são os cortiços. Assim, o Brás deixa de se destacar como um bairro italiano e passa a ser nordestino. Conforme AYALA (1982), "ficou no bairro a "infra-estrutura" montada para receber, ainda que temporariamente, novos trabalhadores pobres, em seus cortiços, pensões e hotéis de má qualidade que margeiam a estação ferroviária. (p.31). Essa autora, vai desenvolver sua pesquisa sobre os aspectos da cantoria nordestina e em um dos capítulos acaba retratando o Brás, como um espaço de encontro dos repentistas nos anos 50, 60 e 70. Ela destaca o espaço simbólico, que o Brás representa para os nordestinos. Ela demarca os anos 50 como o "início da nordestinização do Brás".

A Hospedaria passou a receber o migrante nacional, que chegava na Estação do Brás $^{12}$, ele vem para trabalhar na indústria, na construção civil, na limpeza etc. Esse fluxo permanece até hoje, como tratado anteriormente. Posteriormente, os hotéis e pensões são a segunda forma de abrigar esses nordestinos.

“As ruas mais próximas da Estação Presidente Roosevelt, nome atual da antiga Estação do Norte, são marcadas pela presença de hotéis e pensões de vários níveis e por um comércio varejista mais popular." (REALE, 1982: 58)

Boa parte desses hotéis eram controlados por portugueses e espanhóis, assim como os restaurantes; eram mais de vinte hotéis nos anos 50. Muitos serviam à alta rotatividade e à prostituição. Contam os depoimentos de alguns ex-proprietários, que um desses hotéis criou um Santuário de Nossa Senhora. Quando os nordestinos chegavam deixavam uma contribuição para pagar a graça alcançada e esses mesmos hotéis "embolsavam" a doação.

O cantor e compositor baiano, de Irará, Tom Zé compôs a música Correio da Estação do Brás inspirado na Estação do Norte , que veio intitular seu disco, em 1978:

"Eu viajo Quinta feiral Feira de Santanal quem quiser mandar recado/ Remeter pacotel Uma carta cativantel A rua numerada / $O$ nome maiúsculoso...”

\footnotetext{
${ }^{12}$ A Estação do Brás, bem como as ruas citadas neste capítulo estão representados no mapa no 1
} 
Na praça, em frente à estação ferroviária do Brás, ao lado do Largo da Concórdia, uns anos atrás ${ }^{13}$, havia "Kombis" de agenciadores ou "gatos" que ofereciam empregos de vigias, de faxineiros, de caseiros, trabalhadores na construção civil. Eles agenciavam para dentro e para fora do Estado de São Paulo. Nos depoimentos de nordestinos que chegaram em São Paulo nos anos 50, colhidos por ESTRELA (1999), aparece o registro de agências especializadas "em ludibriar os sertanejos que chegavam" (p. 183) no Brás. Assim, reafirma a autora com esses dois depoimentos, por ela colhidos:

“(...) Tinha no Brás um hotel que chamava Hotel Queiroz, então, eles pegava esse pessoal, que vinha de Imigração, então chegava, vinha o cara, o testa de ferro, chegava lá no hotel: é porque você vai ganhar tanto, vamos com sua mulher, eu pago as passagens e tudo mais, as despesas por consta, vai chegar lá vai trabalhar nisso e naquilo (...) Lidibriava as pessoas (...)” (Antonio Castro Pereira - APUD ESTRELA; 1999: 183)

“Ele chegou a São Paulo em princípios da década de 50, quando 'emprego era mato', e os arregimentadores, 'os gatos', se postavam na 'Estação do Norte' chamando a atenção dos recém chegados:

- Emprego baiano, emprego baiano...” (p. 155)

A imagem do Brás da Malandragem, ocorre desde 1891, quando as atas da Câmara, registram o pedido de providência para os indivíduos oportunistas que se aproveitavam dos recém chegados, segundo AYALA (1982). O bairro, também, foi caracterizado pela desordem; “aflora o mundo da picardia”, ”Brás das malandragens, das brigas, das batidas policiais , do 'rapa'.” (p. 40). Assim, registra o cordel, nos anos 50, A malandragem do Brás, de 1957 (ver no anexo), do cantador Lourival Bandeira.

Tanto o Largo da Concórdia, a Estação Roosevelt ou o Largo da Estação do Norte (Roosevelt) foram as primeiras referências para os recém chegados migrantes nordestinos. Lá era o ponto de parada dos caminhões e depois dos ônibus. Os caminhões "pau-de-arara" paravam na rua, em frente a Avicultura Valença do Norte (no largo da Concórdia, $n^{\circ}$ 126). Em 1950, os "paus-de-araras" são proibidos, embora continuem até meados da década de 50. O primeiro ônibus, pertenceu ao baiano Altino; ele saía do Hotel Carioca, e retornava lotado. As linhas de ônibus foram ampliadas, principalmente

\footnotetext{
${ }^{13}$ Quando fizemos a pesquisa de Iniciação Científica em 1988 era possível ver com tranqüilidade essas peruas.
} 
depois que a Rio-Bahia é asfaltada, em 1963. As agências de passagens e os pontos rodoviários vão para a Rua Cavalheiro, não existia rodoviária.

Simultaneamente, há uma ampliação dos ônibus urbanos e a população vai ocupar os loteamentos periféricos da Grande São Paulo. Muitos terminais municipais são instalados no Largo da Concórdia. A interligação do Brás com a periferia, fortalece o seu centro comercial, para principalmente a população nordestina. Então, como registra AYALA (1982)

"As imediações da Estação do Norte, mais especificamente o espaço compreendido entre a Avenida Rangel Pestana e a Rua Visconde de Parnaíba, partindo da Almeida Lima , que ladeia a Estação do Norte, começou a ganhar características nordestinas, quer pelos transeuntes, quer pelas lojas de comércio. Pequenas lojas, bazares, bares, casas de lanches, “casas do Norte”(vendendo produtos alimentícios regionais), agências de passagens para o Nordeste, pontos de ônibus interestaduais, hotéis e pensões de baixa categoria instalaram-se nesse local.” (p.44)

Atualmente, encontramos nas ruas do Brás, as lojas com produtos típicos, empresas de ônibus que, no conjunto, caracterizam um terminal rodoviário clandestino $^{14}$, transportadoras com seus caminhões, fazendo ligações diretas para o Nordeste e os Forrós. A pesquisa de JACQZ (1982) faz referência à localização de alguns "focos" nordestinos, que evidenciaram certos bairros "bem nordestinos", em razão dos "trens baianos na estação Roosevelt e à presença das agências de ônibus para o Norte.", continua:

"Ali se concentra ainda hoje as lojas tipicamente nordestinas, onde pode-se comprar chapéus de vaqueiros, violão e sanfonas, discos de música sertaneja; encontra-se também os ingredientes típicos da comida nordestina, como óleo de dendê, carne de sol, etc...” (JACQZ, 1982: 107)

\footnotetext{
${ }^{14}$ São 35 empresas: 3 delas são registradas e as outras, clandestinas, como foi relatado em um depoimento e constatado no artigo de jornal (F.S.P.- 27.05.2001)
} 


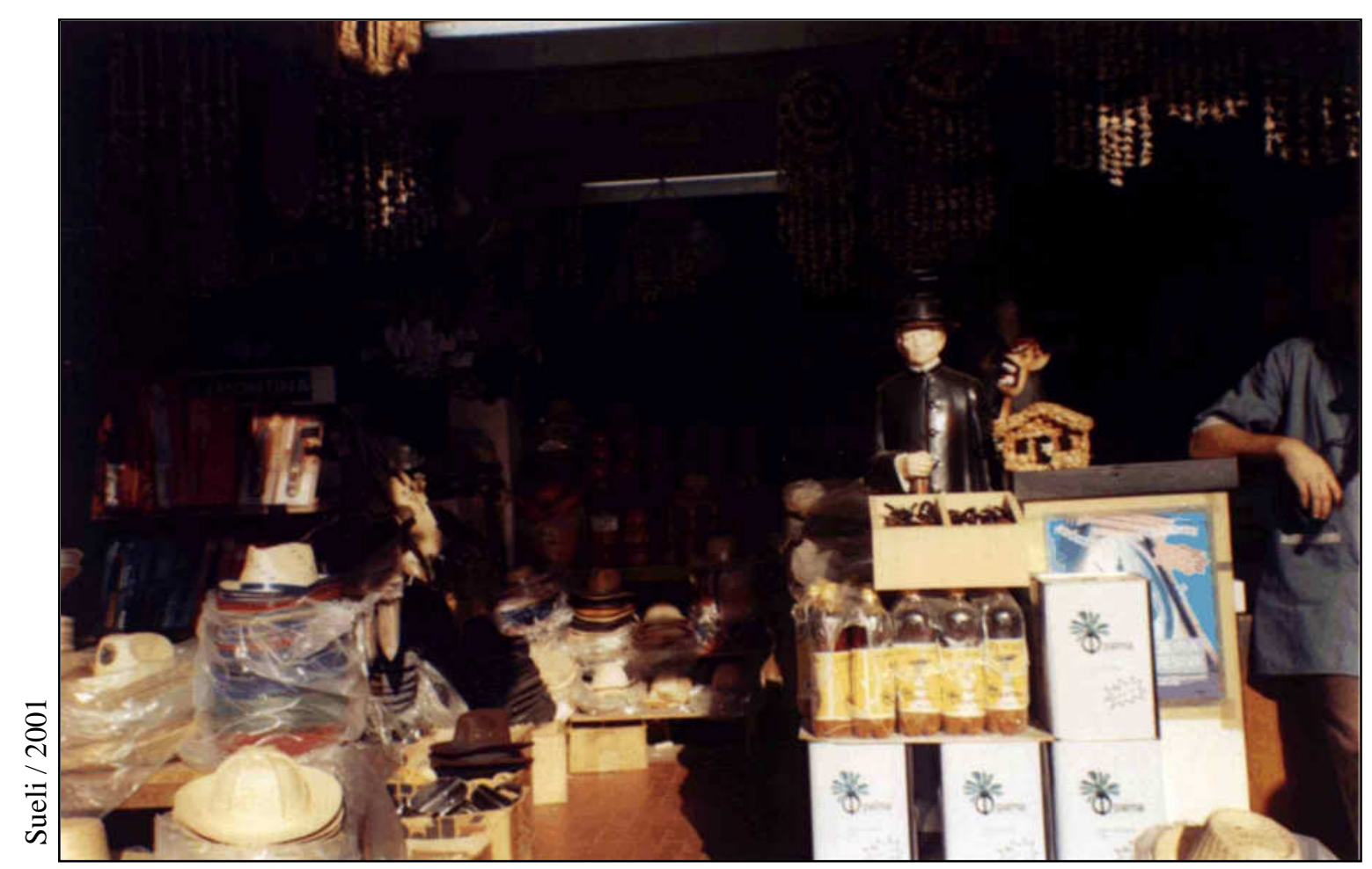

Foto 17: Vários artigos e produtos que servem à comunidade nordestina.

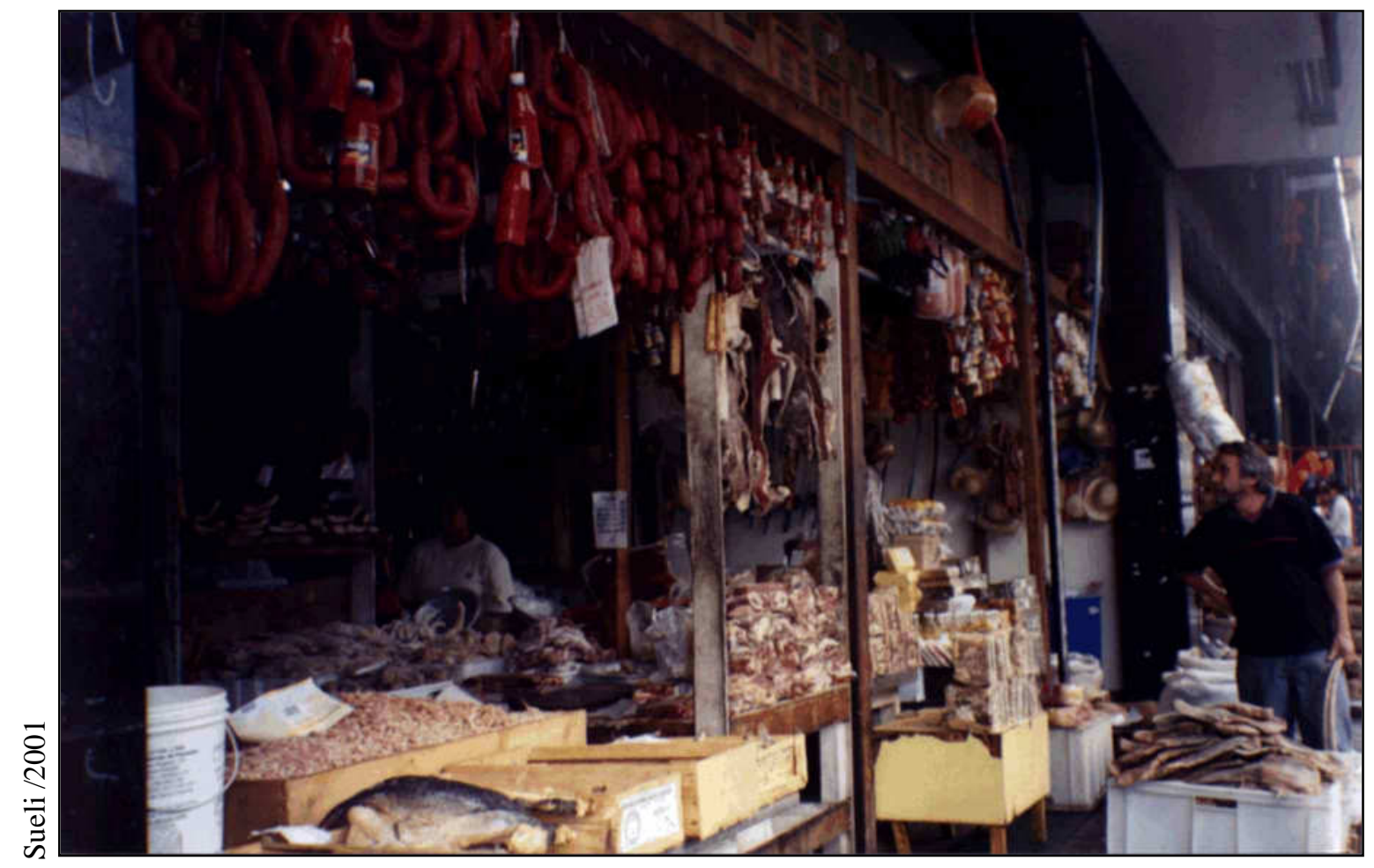

Foto 18: Comércio de alimentos voltados para a culinária nordestina. 


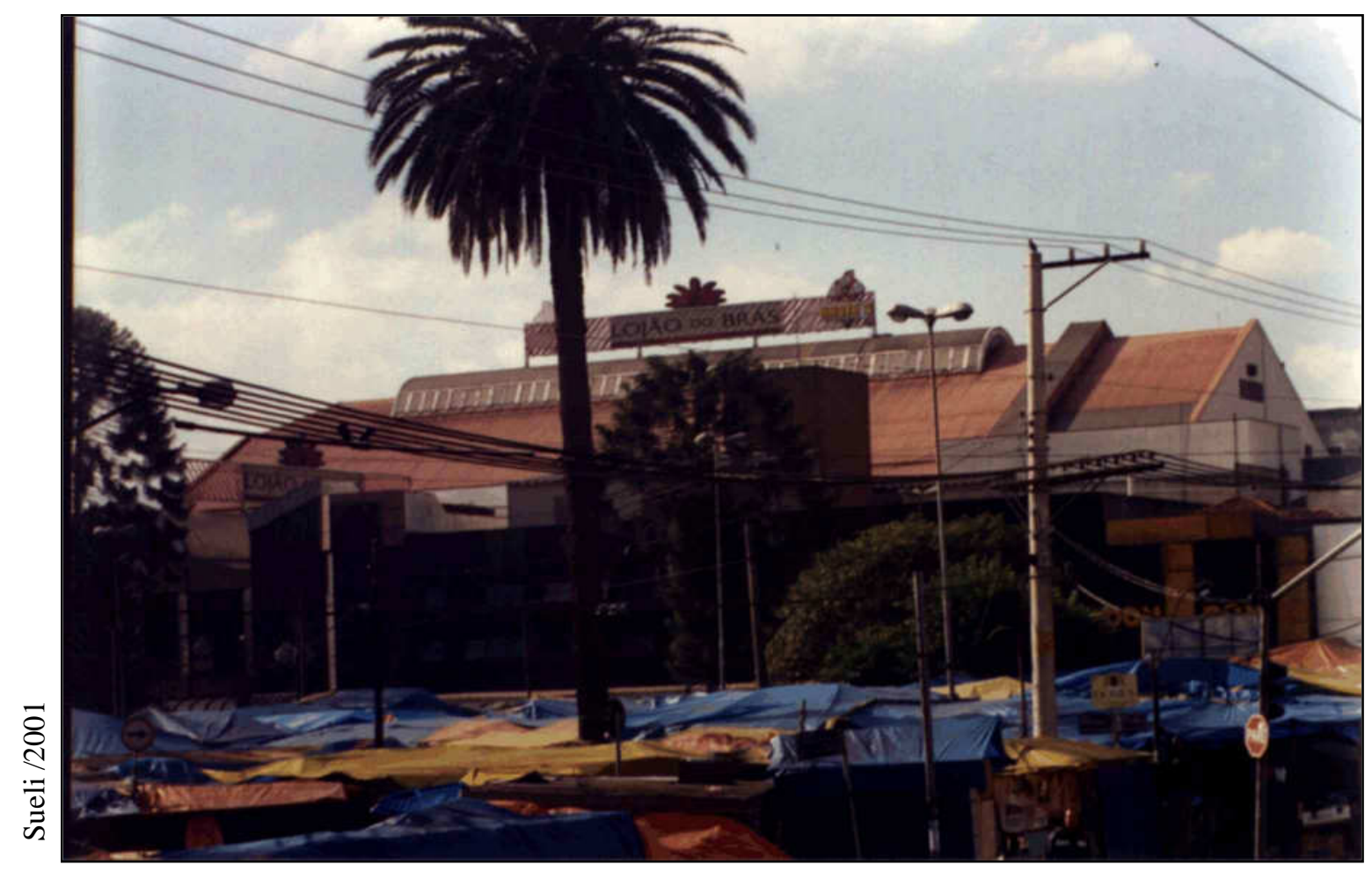

Foto 19: A atual ocupação do Largo da Concórdia.

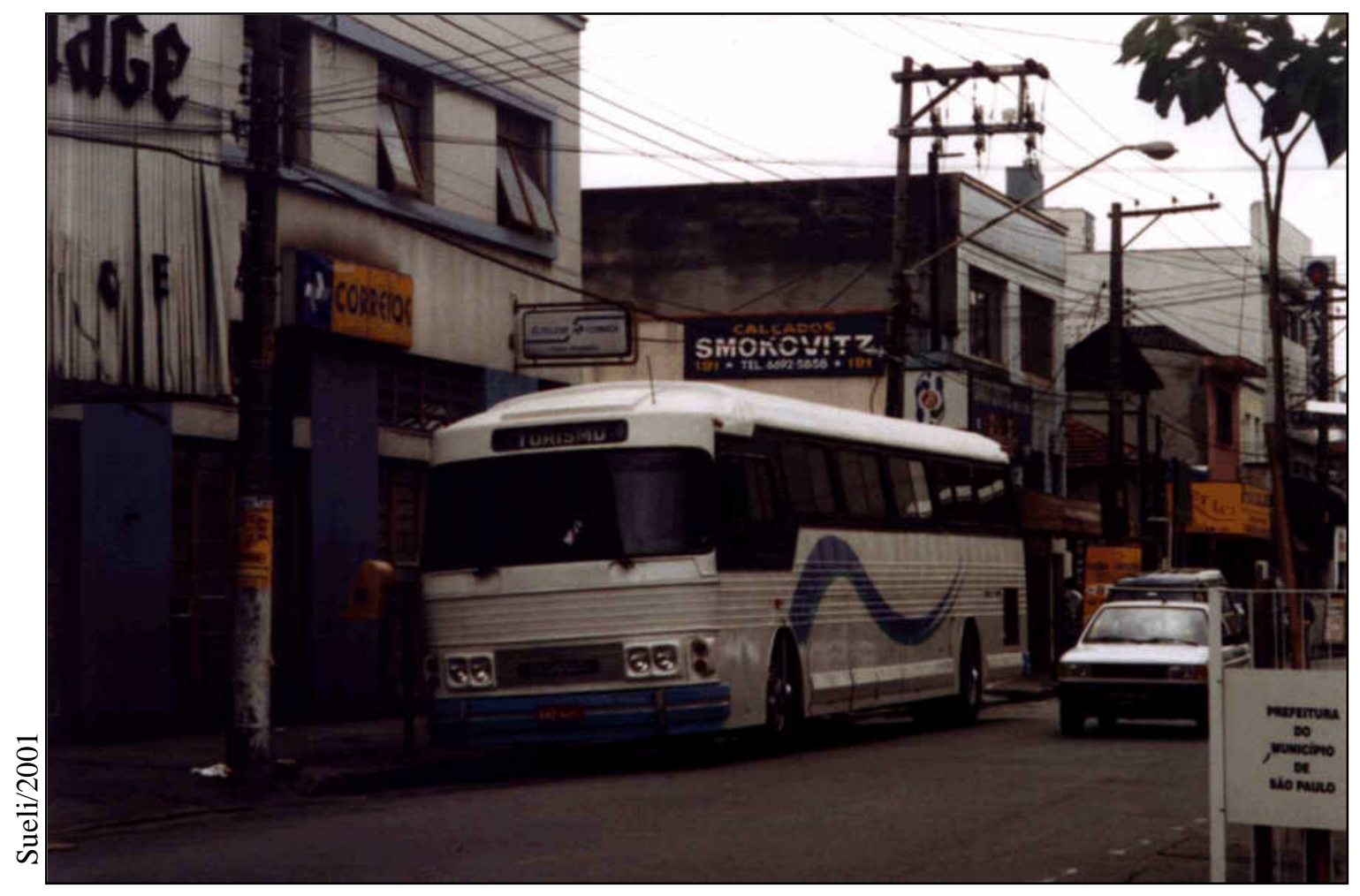

Foto 20: O ônibus das agências clandestinas nem sempre estão em bom estado de conservação. 


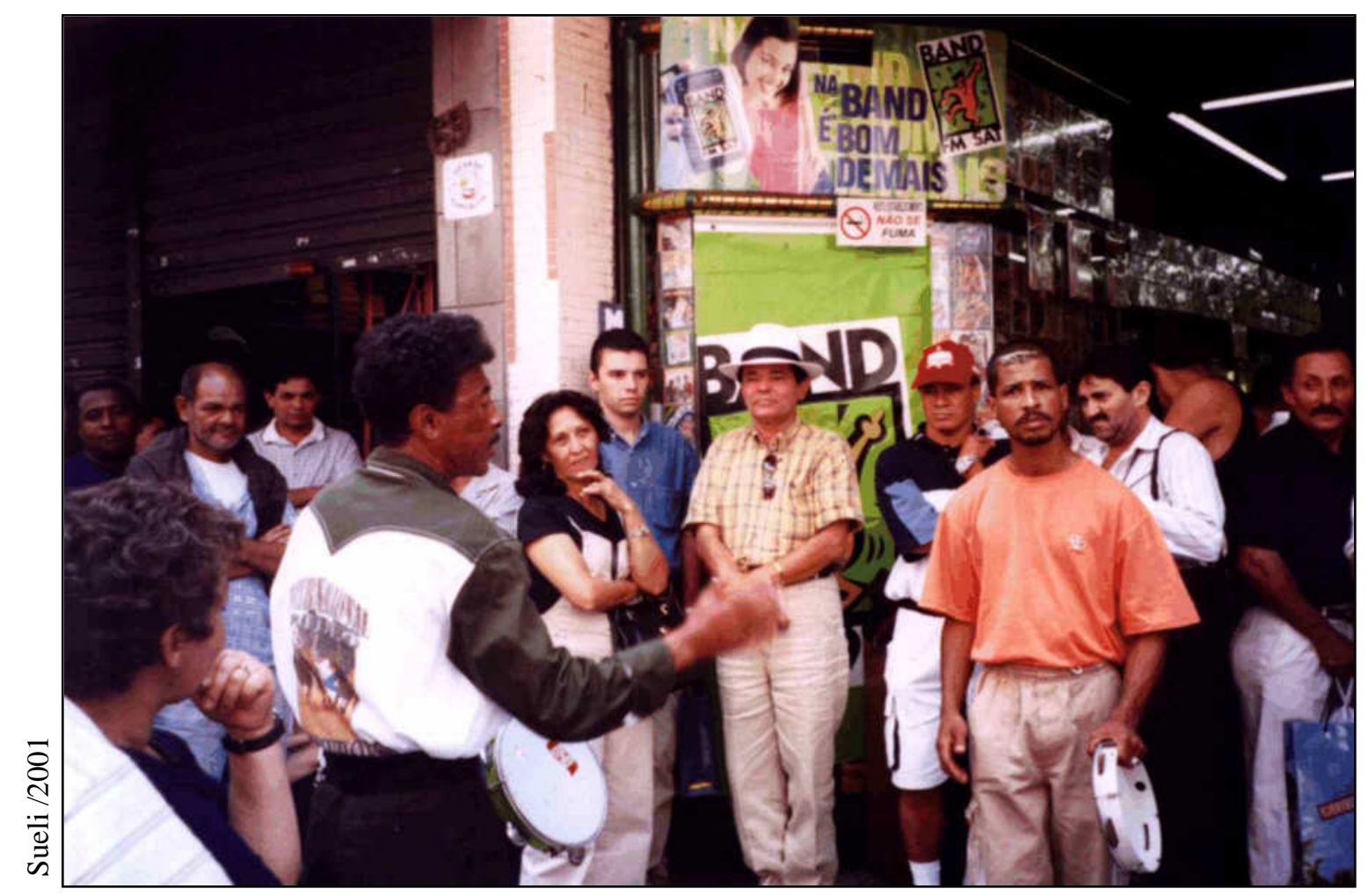

Foto 21: Um show de embolada, com Verde Lins e seu parceiro na rua Coronel Trancoso, ponto de encontro de nordestinos.

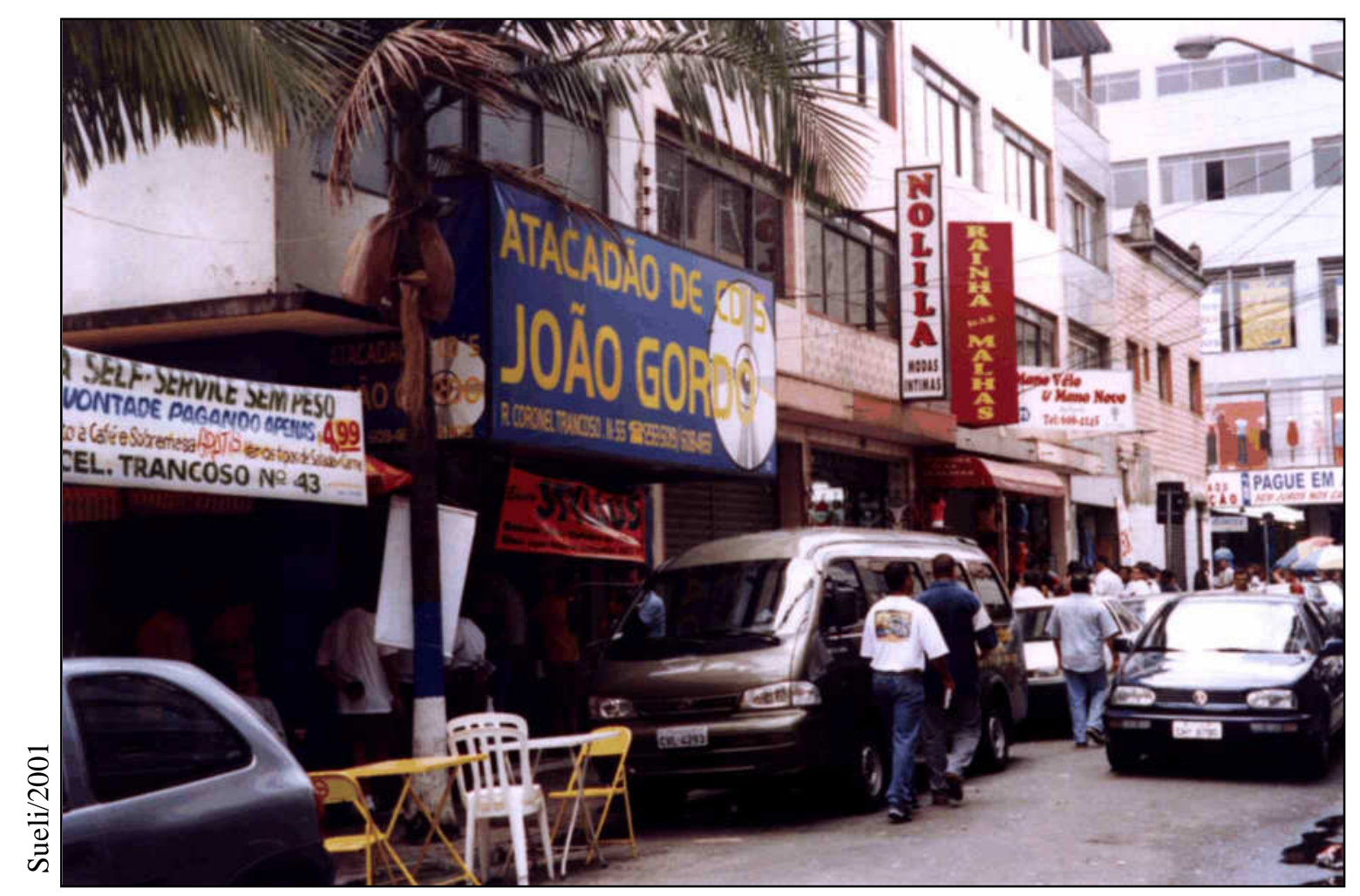

Foto 22: Rua Coronel Trancoso especializada em venda de CDs de forró e onde se localiza o Bar Estrela do Norte. 
Tanto AYALA (1982), como ÂNGELO (1996) registram a chegada dos primeiros, cantadores na "terra da Garoa":

“Guriatã desembarcou em São Paulo, mais precisamente na antiga 'Estação do Norte’ em São Paulo” no dia 10 de dezembro de 1946. Naquela época segundo ele, 'cantoria era sinônimo de vadiagem'”. (p. 69)

Havia uma discriminação intensa naquele período com os nordestinos, em especial os cantadores, cordelistas e repentistas, como mostra o seguinte registro:

“..os cantadores, que faziam do Brás, o seu principal reduto, não reconhecidos, como profissionais do verso e viola, mas sim como arruaceiros, desocupados, pessoas desqualificadas para o trabalho. Isto é, a discriminação era brabíssima, forçando uma enérgica intervenção do compositor e radialista Venâncio (Marcos Cavalcanti de Albuquerque), que à época fazia dupla com Curumba (Manoel José do Espírito Santo) e mantinha um programa de grande sucesso na extinta Rádio Marconi”... “A viúva Maria José de Britto, a dona Zezé, recorda com uma indisfarçável pontinha de saudade.

- Venâncio era uma pessoa conhecida aqui em São Paulo, onde chegou comigo em 1956. Ele sentia muito particularmente o drama de seus conterrâneos cordelistas e cantadores, tanto que os tirou do Brás e os levou para o centro da cidade, numa situação bem melhor do que a de antes, onde tinham a persegui-los constantemente policiais.” (ÂNGELO, 1996: 81)

Vejamos esse registro no fragmento desse cordel:

“Os nossos irmãos do Norte

Sempre vão no Brás

Escutam os violeiros

Pedem tema e tudo mais

Tomando pinga do Norte

Que lembrança sempre traz.
Cada um pede aos poetas que relembre o seu sertão Cantam versos de improviso Tema de amor e canção Comem carne e rapadura Com batida e limão."

(João de Barros $)^{15}$

\footnotetext{
${ }^{15}$ Folheto de Cordel. O que faz o Nordestino em São Paulo. p.6-7.in JACQZ e in ESTRELA (p. 73).
} 
Essa perseguição aos cantadores, repentistas vai ser mais intensa nos anos da ditadura militar, sendo que entre 66 e 70, eles deixam de se encontrar nos bares do Brás ${ }^{16}$.

A brutalidade no desarmamento dos nordestinos que chegavam na Estação era constante, como lemos na pesquisa de ESTRELA (1999):

"Nas décadas de 40 e 50, temos informações de que a polícia paulista se estabelecia na "Estação do Norte "para desarmar os indivíduos que procediam de vários pontos do Nordeste, em deslavado abuso.” (p. 122)

A 'Estação do Norte', representava também espaço de lazer, naqueles anos; era o ponto de encontro dos conterrâneos. Muitos nordestinos, que moravam em São Paulo, iam todos os fim de semana, religiosamente, à Estação do Norte para ver os "nortistas chegando" (p. 166) ou então, "marcam encontro na frente da Estação do Norte por causa do vício do tempo do ônibus." (Januário in AYALA, 1982: 44).

Na tese de AYALA, ela recupera historicamente o ponto de encontro das cantorias no Brás como, em 1950, a avilcultura Valença do Norte, no Largo da Concórdia; Bar Damasco, na rua Almeida Lima; em 1960, havia Bar do Rato Branco, na R. Almeida Lima; Bar e Lanches Aeroporto dos Nordestinos, na Rua Cavalheiro; Recanto dos Poetas Repentistas, na rua Paulo Afonso. Nos anos 70, surge a Casa do Conterrâneo ou Academia dos Poetas Repentistas, na R. Brigadeiro Machado. Nesse momento, muitos intelectuais e estudantes universitários freqüentavam o espaço, também. O Recanto dos Poetas Repentistas era freqüentado pelos trabalhadores de menor poder aquisitivo, e a casa do conterrano (sic) pela classe média e universitários. O Bar do Zé Minhoca, na R. Paulo Afonso foi um dos últimos a receber as cantorias no Brás, nos fins dos anos 70. Ela se muda para outros espaços da Grande São Paulo. Encontramos alguns elementos materializados que demarcam a presença nordestina como a rua Coronel Trancoso, com lojas de CDs especializada em Forró, que no sábado se torna um ponto de concentração, onde, também, ocorre um "arrastapé” no bar Estrela do Forró. Na rua Almirante Barroso está localizada a Editora Luzeiro, especializada em literatura de cordel. Ela existe há 80 anos e pertencia a portugueses. Nas ruas em torno da Estação, o comércio de alimentos e outros artefatos típicos do nordeste é grande, tomando alguns quarteirões. Na rua

\footnotetext{
${ }^{16}$ Apenas Zé Miguel insistia em se apresentar e foi preso várias vezes.
} 
Gomes Cardim funciona a sede da ANESP -Associação de Nordestinos do Estado de São Paulo, essa entidade funciona há 13 anos. Ela publica um jornal chamado "Eco Nordestino" e funciona como uma associação de bairro. Veja parte de seu editorial:

“O Eco-Nordestino é o único jornal dirigido à comunidade nordestina e luta pela mesma. Já fora plantado várias árvores em parceria com a Secretaria do Verde e Regional da Sé. Acreditamos que o asfalto da rua Gomes Cardim estará concluído até o final do mês, algumas lixeiras também foram instaladas, a Rua de Cultura e Laser já inauguramos, na rua 21 de Abril, 188 já inauguramos a biblioteca, sala de computação e a creche já está atendendo 10 crianças e alojamento para algumas familias. Junto a VITAL TURISMO e outras agências temos conseguido passagens para ajudar alguns conterrâneos a voltar para sua terra natal.

Ao anunciar no Jornal Eco-Nordestino você estará ajudando neste projeto, que é a nossa luta. Não queremos apoio de nenhum Órgão Governamental, só assim nos sentimos livres, o que queremos e o que estamos realizando e levar ao sacoleiro, ao médio e pequeno empresário as empresas aonde eles devem comprar em São Paulo. Pois os ônibus que chegam do norte-nordeste enfim, do Brasil inteiro, são os nossos homens e mulheres que vão gerando renda neste país.

Queremos agradecer aos nossos patrocinadores que é com o anúncio deles que mantemos os nossos projetos, nas mãos das crianças de hoje está o futuro do amanhã que já começou. “

(Francis Bezerra, outubro de 2001)

Como o texto mostra, a prefeitura junto com a associação, criou a rua de Cultura e Lazer Nordestina; nessa rua ocorrem brincadeiras para as crianças e um forró no palco. $\mathrm{Na}$ sua inauguração estavam presente três mil pessoas, segundo o artigo do jornal.

Outros depoimentos, mostram o Brás, como o local de estudo, noturno, havendo cursos de alfabetização e técnicos, para aquela população não escolarizada que estava chegando na cidade. Dessa forma o Brás foi se consolidando como um território dos nordestinos. 
Os migrantes, por sua vez, buscam novas estratégias de sobrevivência, na economia informal, seja como camelôs ${ }^{17}$, que se multiplicam pelas calçadas, seja como catadores de papel ou até mesmo como retalheiros (referente à venda de retalhos ou resíduos de tecidos das confecções).

A Hospedaria do Imigrante foi desativada do seu papel inicial e se tornou o Museu da Imigração e albergue. A paisagem das ruas do Brás torna-se caótica: muitas lojas, propagandas coloridas, aglomeração de camelôs nas calçadas que dificultam a passagem dos pedestres, além da poluição sonora provocada pelos comerciantes. Para o antigo morador, o Largo da Concórdia representava o espaço de lazer, footing como D. Dina nos contou, e hoje está deteriorado; isso aparecerá na afirmação do Sr Jaime:

“Ah! Bom, era bem mais bonito. Hoje é o camelódromo, aí, imenso. Desde a década de 50 pra cá,... esse fluxo de nordestinos que desembarcavam aqui próximo, ali numa ruazinha do lado lá que era uma espécie de aeroporto, o pessoal chamava de aeroporto de nordestinos, mas vinha os ônibus do Nordeste..."

Conversando com alguns antigos moradores do Brás, todos atribuem a queda da qualidade de vida do bairro e a sua fragmentação, à chegada do migrante nordestino; é um imaginário que acaba sendo discriminador e que cria estigmas, os mesmos que os migrantes italianos sofreram no começo do século pela aristocracia cafeeira.

Quando EVERS e outros discutem as diferentes formas de organização nos movimentos e a troca de experiências, ela fala da percepção dos moradores dos bairros, os quais fixam-se nesses tipos de distinção "para guardar distância e hierarquia, dentro dessa estrita vizinhança e miséria comum. Em alguns bairros existe uma linha divisória invisível entre a parte do bairro em que vive gente "decente" e aquela que mora gente considerada 'má"'. (EVERS et al., 1982: 128)

O bairro reproduz em seu interior, em escala reduzida, a segregação urbana entre os bairros 'bons' e os 'maus' à qual deve a sua própria existência. Ainda EVERS et al. continuam e citam o exemplo de São Paulo:

"Nos bairros periféricos de São Paulo encontramos uma clara escala de prestígio social conforme a procedência: primeiro, os que nasceram em São Paulo (centro industrial); segundo, os imigrantes de Minas Gerais (mineiro,

\footnotetext{
${ }^{17} \mathrm{~A}$ sede do sindicato dos Camelôs está situado no Brás, sendo referência para os Camelôs, muitos, Nordestinos.
} 
industrial e agrícola); terceiro, os do Sul do país (agricultura de clima temperado, mais intensiva); e por último os do Norte (agricultura tropical, mais extensiva)." (EVERS et al., 1982: 128)

As autoras concluem que não devemos estabelecer uma situação de classe comum, pois indivíduos com características heterogêneas que ocupam o mesmo bairro, como o que ocorre no Brás, possuem consciências e experiências diferenciadas. As autoras propõem, para superar essas distâncias, as lutas coletivas, em que as experiências são unificadoras; percebendo as causas comuns dos problemas, esses grupos estarão acima das diversidades.

Não podemos deixar de citar outro grupo étnico que veio mais recentemente ocupar as vilas e cortiços do Brás - são os bolivianos, que trabalham na costura para os coreanos nas suas confecções ou em suas próprias moradias. SILVA (1997), em sua dissertação de mestrado, registra as condições insalubres e de escravidão dos bolivianos, estudando a sua trajetória em São Paulo. Assim como os nordestinos, também os bolivianos representaram a quebra das relações de vizinhança para o antigo morador do Brás italiano, vejamos isso na fala da família Agnellos que mora em uma Vila Operária:

“Italianos, descendente de italianos, somos só nós duas aqui, (...). Eles têm outros costumes. (...) Eles ficam até tarde, eles põem alta as músicas para poder trabalhar.” (Maria Agnello)

“Era o Brás... O Brás era uma maravilha, tudo família... Difícil... tem uns que nem cumprimenta a gente. Incrível viu! (...) Ah! Maria, tá horrível”. (Angelo Agnello)

"Hoje não, eu passo esporadicamente, aqui em alguma circunstância qualquer. Hoje é passagem rápida, por aqui a gente se sente estranho, sente até uma certa hostilidade até no ambiente..." (Jaime Cuberos)

Esses sentimentos dos antigos moradores do Brás em relação ao Bairro, só podem ser explicados pelos processos que eles estão envolvidos e não pelo movimento aparente que os novos moradores, ou as novas correntes migratórias representam. Vejamos a leitura de MARTIN sobre esse distanciamento e hostilidade do antigos moradores: 
"Além disso a pulverização do centro tende a promover a completa perda de identidade entre o habitante e o espaço, o que repercute na psicologia $e$ cultura." (MARTIN, 1984: 164).

O Brás hoje se tornou um bairro de passagem, um bairro conhecido em todo o território nacional pela quantidade de sacoleiros que vão comprar as mercadorias que são revendidas por todo país. Para o antigo morador, já não existe mais identidade com o lugar, o que resta são as memórias. Porém, ficam aqui algumas questões. Qual será o significado do Bairro para os novos moradores nordestinos, bolivianos e coreanos? Existe a construção de relações de vizinhança e solidariedade dentro desses grupos? Enfim, são questões que merecem estudos mais aprofundados.

O Brás passa, então, a ser um espaço fragmentado, sofrendo com o processo de metropolização. A Grande São Paulo cresce mais uma vez atraindo a mão de obra, principalmente nordestina, com o desenvolvimento industrial.

As fábricas instalam-se, nesse momento, ao longo dos eixos viários, como nas rodovias Anchieta, Castelo Branco, Fernão Dias, Dutra, Imigrantes, Anhanguera etc. Muitas das fábricas localizavam-se nos municípios periféricos, no entorno da cidade de São Paulo como Osasco, região do Grande ABC- municípios de Santo André, São Bernardo e São Caetano- Cotia, Guarulhos etc. Nessas áreas se fixou a mão-de-obra necessária, formando novos bairros na franja da metrópole e não mais nas vilas operárias ou os cortiços centrais que abrigavam esses trabalhadores.

Na leitura de "A Estrutura Territorial da Metrópole Sul Brasileira" de Flávio VILLAÇA (1978) o autor mostra como o crescimento espacial da metrópole segue os eixos da ferrovia e das rodovias que determinam a sua estrutura territorial.

"No que toca aos meios de transporte, a atual estrutura territorial das metrópoles do sul do país foi muito influenciada pela ferrovia. Não apenas no tocante a direções e intensidade da expansão física, mas também quanto à distribuição territorial das camadas sociais, o desenvolvimento, localização, tamanho e natureza dos subcentros de comércio e serviços, além, evidentemente de ter influenciado a localização das indústrias.” (p. 91)

Veja nos mapas a seguir o traçado da linha férrea, que liga o Brás a diversos municípios da metrópole. 


\section{REGIÃO METROPOLITANA DE SÃO PAULO - SP}

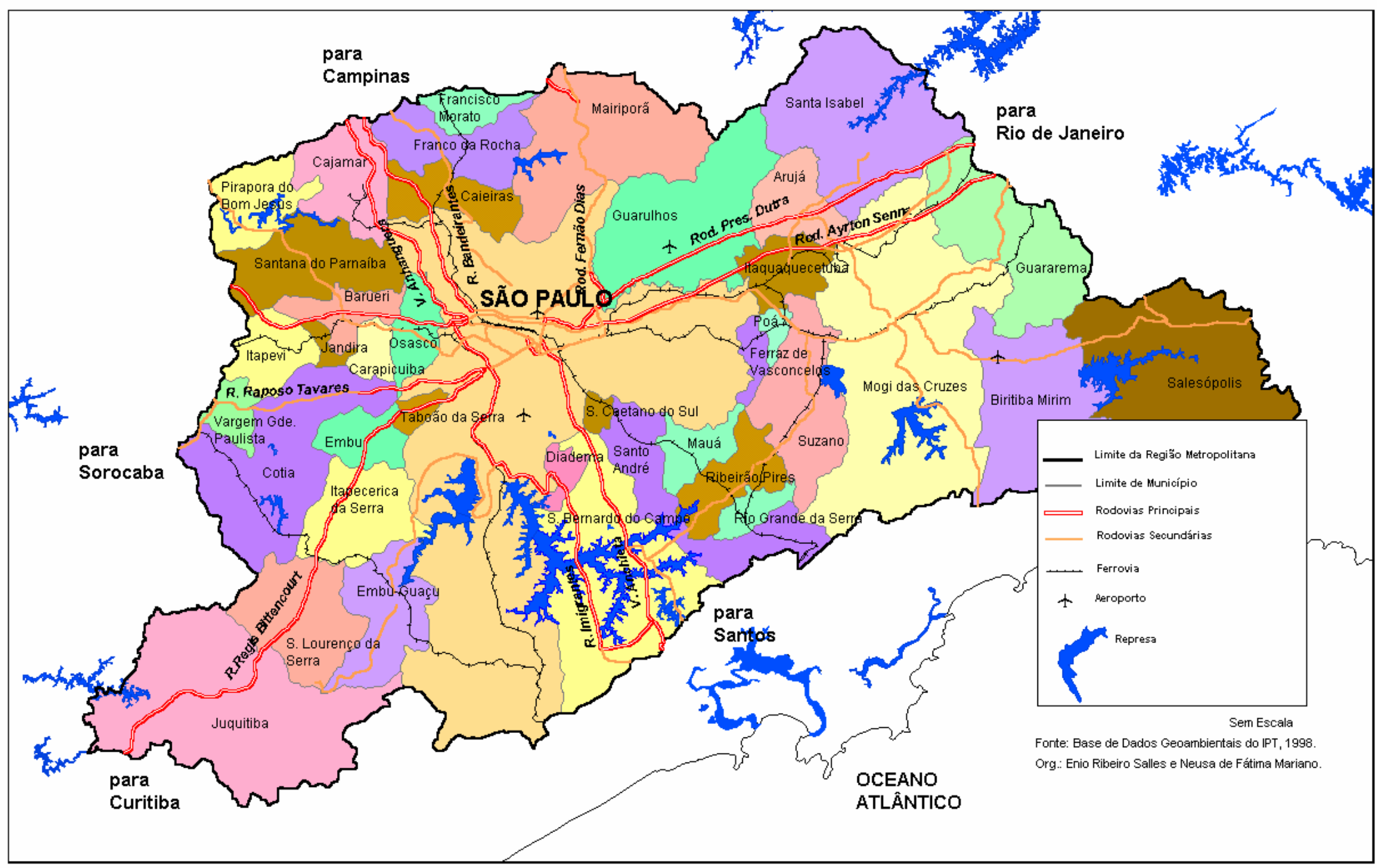




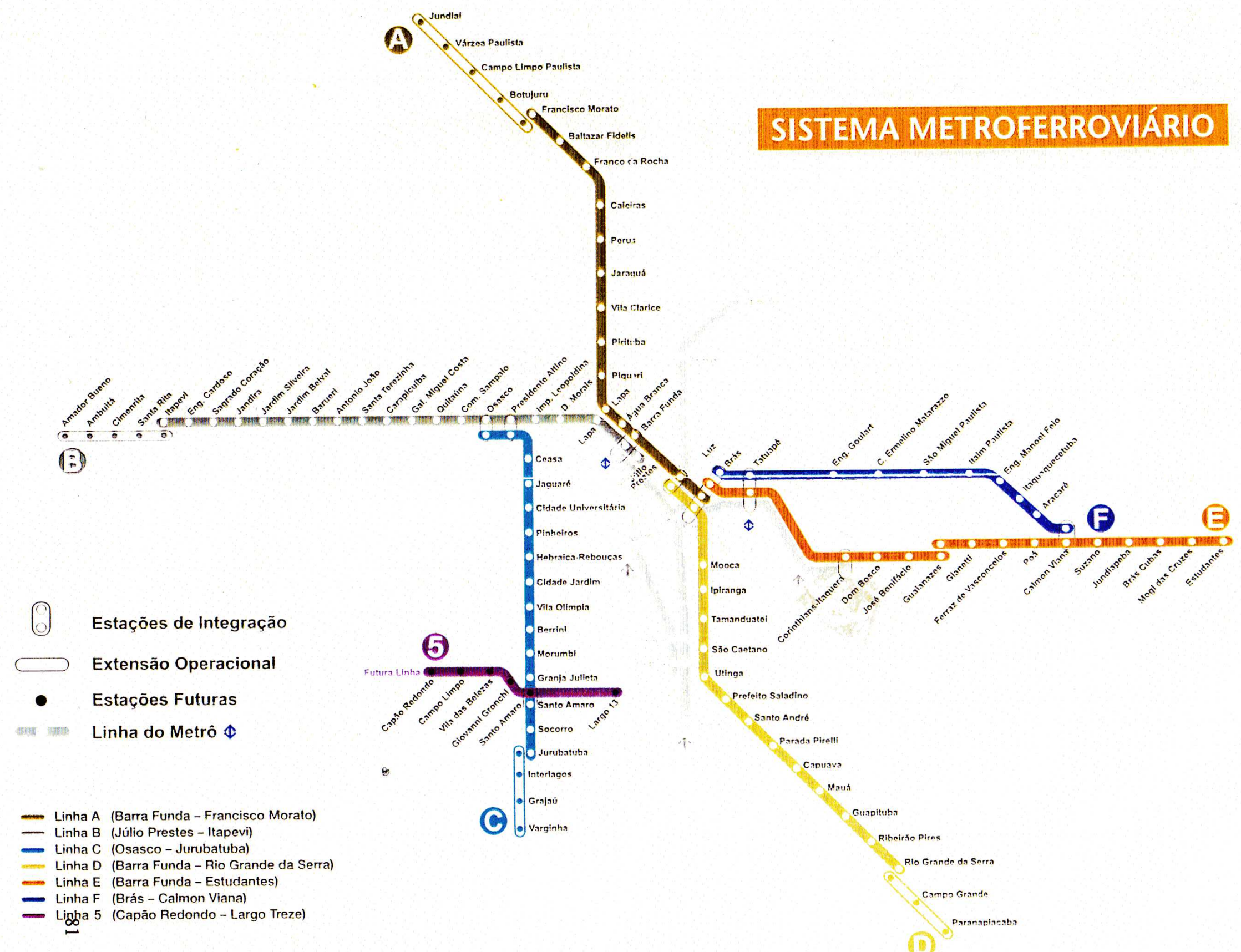


A valorização do solo e sua renda é um elemento significativo para analisarmos essas transformações. O Brás torna-se um bairro central que tem parte da sua área sendo valorizada para o comércio, e o preço do "ponto" se eleva, enquanto uma outra parte está em processo de desvalorização, principalmente para o uso de residências e indústrias de grande porte.

“O preço seleciona o uso, fazendo surgir simultaneamente a segregação social no espaço urbano e a deterioração da centralidade." (MARTIN, 1994: 112).

O Bairro começa a ser abandonado pelos imigrantes enriquecidos pelo progresso de suas oficinas; outros, são expulsos pela impossibilidade de pagar altos aluguéis e procuram loteamentos recém formados nas periferias da cidade, junto às novas áreas industriais. Ao estudarmos o processo de metropolização, encontramos em LANGENBUCH (1971) elementos que melhor identificam esse crescimento: Para o autor o início da metropolização da Grande São Paulo ocorre entre o período de 1915 à 1940. Ele recupera a formação dos novos loteamentos, originando novos bairros. Enquanto isso, o Brás sofre algumas transformações - "A compactação da cidade , a partir de 1940, envolve a área do Brás." (p. 179)

Comparando os anos 40, 50 e 60 houve um decréscimo da população no bairro do Brás. O recenseamento mostra uma variação da população no Brás - em 1940 havia 80 225 habitantes, em 1950 decaí para 68.135 habitantes e 1960, continua declinando para 64.061 habitantes. Esses dados são o apoio para a seguinte análise:

“O decréscimo demográfico, verificado nos três subdistritos referidos corresponde, visivelmente, a uma retração do uso residencial do solo, que cede diante da expansão local do setor terciário de atividades (Sé, Brás) e das indústrias (Brás, Moóca).” (LANGENBUCH, 1971: 252)

Seu adensamento, que vem desde a última década do séc. XIX, é viabilizado pela ferrovia e posteriormente pelo metrô. Meios de transporte que permitem a acessibilidade, atraindo atividades centrais e pessoas, segundo a pesquisa de VILLAÇA. Elemento importante para compreender nosso objeto.

O Brás passa pela política do arrasa quarteirão. Para efeito de ilustração seria bom salientar que para a construção da Radial Leste, praticamente quase $20 \%$ (vinte por cento) dos imóveis foram demolidos; depois veio a construção do Metrô e mais uma vez a população do Brás seria sacrificada. A descaracterização do bairro foi muito 
rápida, principalmente a perda da solidariedade de vizinhança e o respeito pela coletividade.

O Brás do comércio expande-se nessa fase do processo de metropolização. Vamos recuperar a gênese do comércio do Brás, baseado na pesquisa e reflexão de VILLAÇA (1978). A importância do Brás como bairro comercial foi ressaltada nessa dissertação, concluindo ser esse o primeiro subcentro comercial das metrópoles que foram estudadas (Rio de Janeiro, São Paulo, Porto Alegre e Belo Horizonte) pelo autor.

“o primeiro subcentro diversificado de negócios, esse subcentro é popular pois atende a uma zona de influência onde predominam as camadas de baixa renda." (p. 108)

As primeiras atividades comerciais nascem com os imigrantes ou descendentes de italianos que acumulam capital e investem nessa atividade, como segue a firmação:

"O Brás foi o principal núcleo de imigrantes italianos que se formou em São Paulo no final do século passado. Ali se enquistou um grupo étnico que inicialmente viveu bastante segregado do restante da população paulistana. Isso muito contribuiu para que o Brás se tornasse um bairro com intensa vida própria, diferente da do restante da cidade e dela independente. Essa segregação inicial fez com que seus moradores freqüentassem pouco o centro da cidade e com isso criou-se, no próprio bairro, uma grande e prematura demanda para o comércio e serviços. Até o início dos anos 40 o Brás permaneceu quase como uma cidade autônoma dentro de São Paulo. O grande desenvolvimento de suas lojas e serviços é uma clara manifestação desse isolamento, pois reforçava-o ao mesmo tempo que se beneficiava dele." ( $p$. $321-322)$

A pesquisa de REALE registra o inicio do comércio no Brás da seguinte maneira:

"Paralelamente ao surto industrial, foi se desenvolvendo também o comércio do bairro. Estendia-se sobretudo ao longo da Av. Rangel Pestana, desde a Caetano Pinto até as porteiras. As principais casas eram: a "Fricana" de fazendas, a “Casa Almeida e Castro”, de louças, a “Joalheira Laurentis”, a casa de móveis "Paschoal Bianco" e a "Casa Pirani". Esta última, fundada 
por Rodolfo Pirani em 1886, dedicava-se inicialmente ao ramo de importação e objetos para presentes.” (REALE, 1986: 24)

Esses elementos nos subsidiaram para entender que o Brás, enquanto bairro comercial, não surgiu depois do recuo da sua industrialização, mas nasceu concomitante ao processo de desenvolvimento industrial. O Brás é sempre lembrado como o berço da industrialização, mas pouco foi tratado como "o berço do comércio".

Vejamos o desenvolvimento comercial, como segue o fragmento abaixo:

“O Brás importante bairro de São Paulo, já podia ser considerado um subcentro na década de 20. Nos anos 40, as lojas, cinemas e restaurantes do Brás se incluíam dentre os maiores de São Paulo. Nos anos 50, as lojas do Brás abriam filiais no centro de São Paulo.” (VILLAÇA, 1978: 309/325).

Além de explicar o processo do desenvolvimento comercial, em razão da segregação dos migrantes italianos e portanto gerando uma certa "independência" do comércio central, ligado as elites. Ele indica outros fatores que estimulam esse desenvolvimento como:

"Brás é fruto da Estação do Norte, ou que esse terminal ferroviário foi fator determinante do surgimento do Brás, como grande subcentro diversificado.” (p. 122)

E ele complementa:

“Entretanto, existe base teórica e empírica suficiente para se acreditar que o terminal ferroviário apenas, não explica suficientemente a permanência e o porte do Brás como centro comercial.” (VILLAÇA, 1978: 123).

Outro fator importante que vai explicar a expansão desse comércio e que será mais bem discutido no próximo capítulo é o mercado consumidor composto por uma população de baixa renda, isto é, a inclusão dessa população na sociedade de mercado.

"Foi assim que, à medida que as camadas populares ascendiam como mercado consumidor, suas lojas e serviços começaram a aparecer também nos centros de nossas metrópoles, nas áreas abandonadas ou desprezadas pelos estabelecimentos que atendiam as elites.” (VILLAÇA: 1978: 297) 


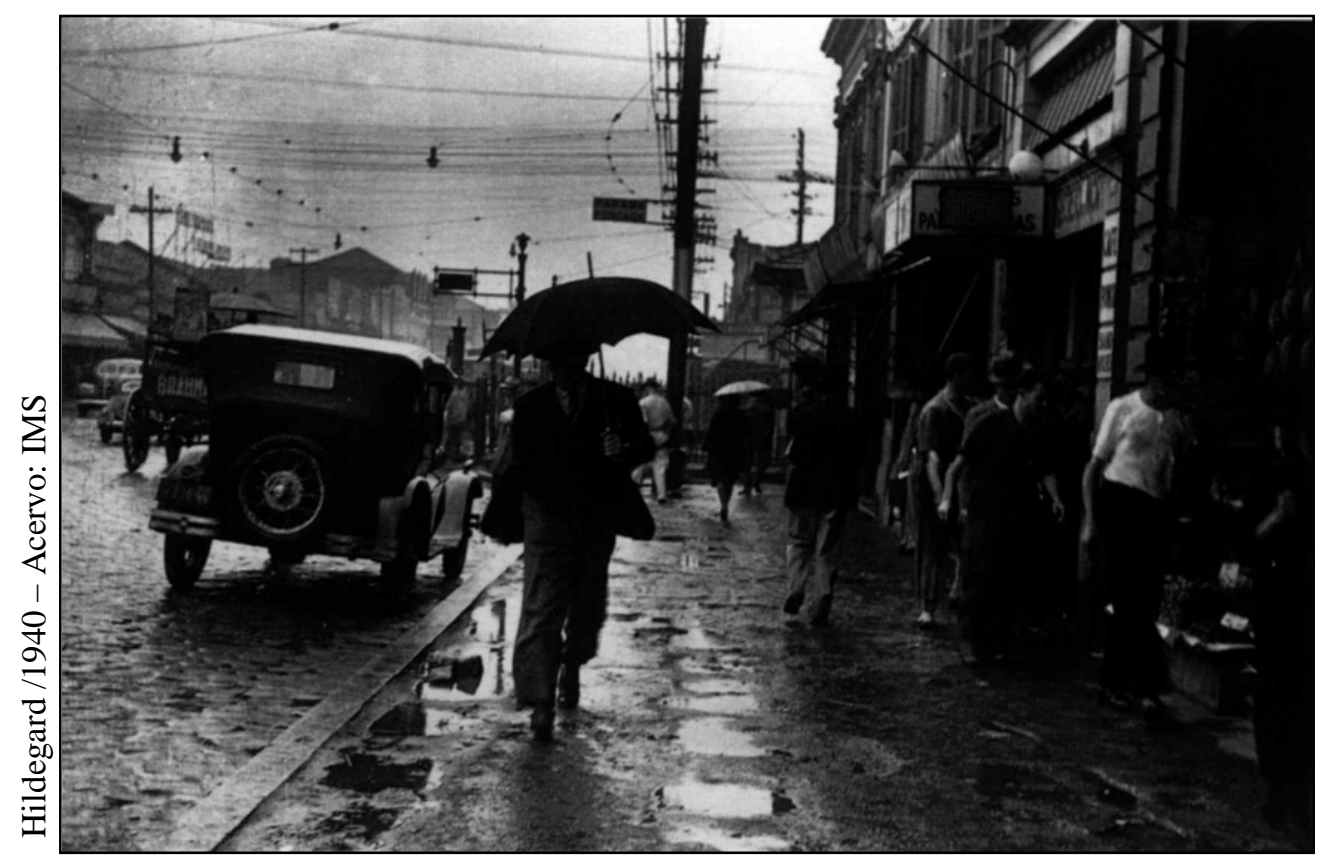

Foto 23: O comércio na Av. Rangel Pestana em 1940.

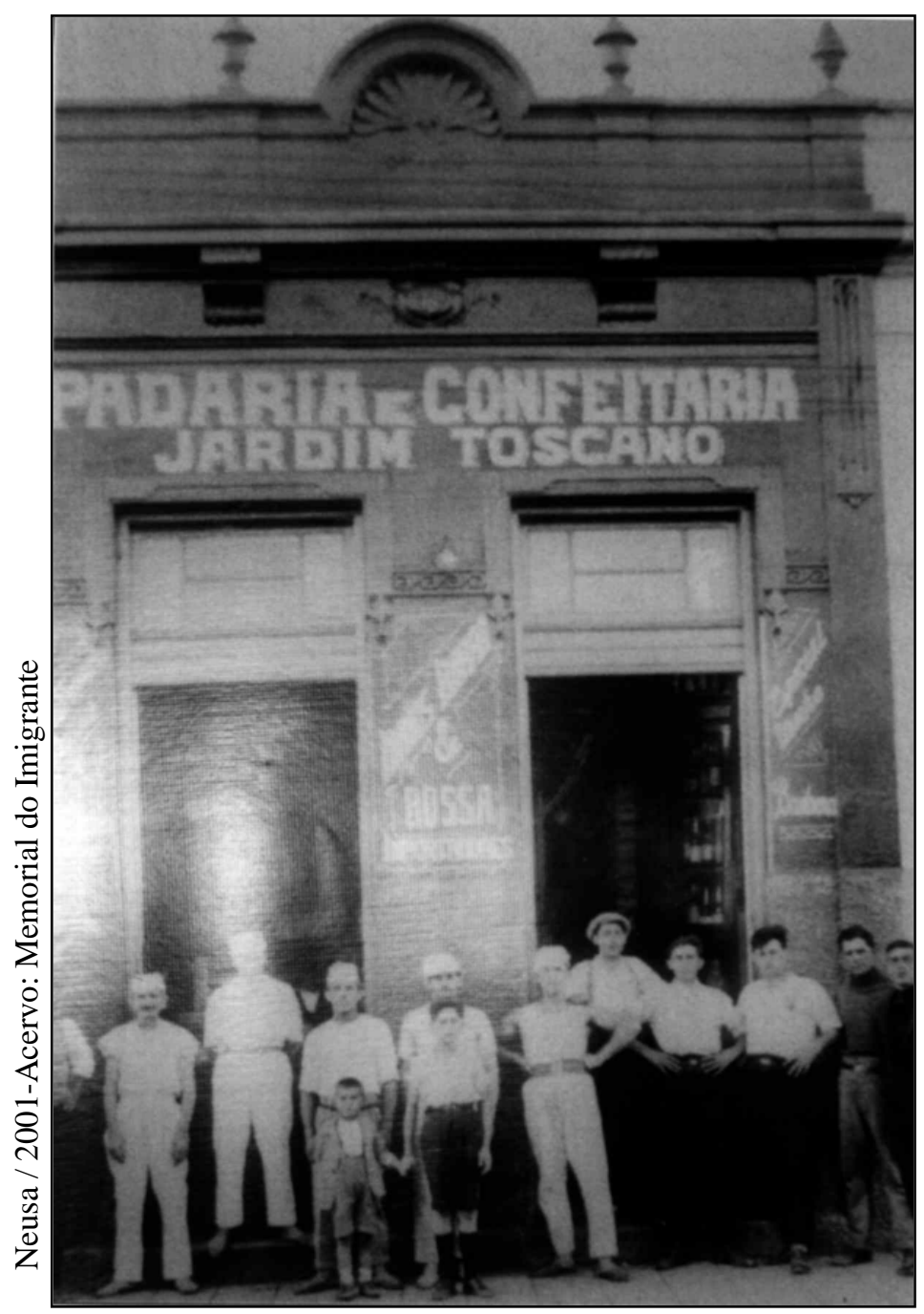

Foto 24: Padaria de imigrante italiano no bairro do Brás. 1926. Coleção Roberto Barra. 
Segundo ANDRADE, a pesquisa de VILLAÇA mostra uma "outra via de ascensão". Se por um lado a indústria tradicional recuou, como vimos anteriormente, o comércio e a indústria de confecções expandem-se. Caracterizando o bairro de uma outra maneira. Vejamos algumas considerações sobre a organização do comércio nas ruas do Brás:

“a rua Piratininga é o centro de peças usadas e máquinas, mas também com o ramo do couro e madeiras, que aos poucos vai ocupando a rua do Gasômetro, ou então também o de roupas, articulado às pequenas fábricas em torno das ruas Oriente e Maria Marcolina, reduto da colônia 'oriental' do Brás (árabes, judeus, e agora também coreanos). (...) O comércio atacadista se fortaleceu, o que indiretamente ajudou a deterioração do Bairro.” (MARTIN, 1984: 169, 172)

O estudo de REALE, publicado em 1982, identifica essas especializações no centro comercial do bairro, que se expandiu e atualmente ocupa uma área muito maior que a citada nessas pesquisas.

“O centro comercial do bairro é a Av. Rangel Pestana onde se localizam as melhores lojas e as casas bancárias. Nas ruas Oriente e Maria Marcolina concentram-se fábricas de confecções que vendem diretamente ao consumidor, seja no varejo, seja no atacado. Já a Rua Piratininga vai caracterizar-se pela sua especialização no comércio de peças e acessórios para automóveis e pelas lojas de ferro velho.” (p. 51)

$\mathrm{Na}$ rua Bresser e arredores, vemos uma grande quantidade de lojas com artigos de cama e mesa, voltado para a classe de baixa renda, atacado e varejo. Enfim, as ruas do Brás se especializaram em determinados setores, de acordo com as mercadorias, possibilitando ao consumidor maior diversidade e a proximidade dessas unidades facilita o seu maior consumo, pois elas são uma referência, tanto em escala local como nacional, e por ser uma referência atraem o maior número de consumidores. Para MARTIN, o fortalecimento do comércio atacadista auxilia no processo de deterioração.

O Brás passa por um processo de recriação, onde a indústria de confecção e o seu comércio vai se expandindo pouco a pouco, até a sua hegemonia nas ruas do bairro. $\mathrm{O}$ crescimento urbano implica uma reorganização desses espaços já ocupados. A indústria e comércio de confecções, vestuário em geral, além do fato de ser hegemônica, 
alimentará com o seu rejeito um outro comércio: retalhos e resíduos, o objeto de nosso estudos. Então resolvemos estudar um pouco sobre o crescimento dessas confecções no bairro.

O crescimento dessa indústria de confecções está relacionado com o crescimento de outra corrente migratória, que foi ganhando grande visibilidade pelas ruas do Brás são os coreanos que migraram para o Brasil, predominantemente, São Paulo. Assim, recuperar a evolução da indústria e comércio de retalhos é tratar, também, das estratégias de inclusão dos coreanos. Para realizar tal percurso nos reportamos à dissertação de CHOI (1991), como segue a síntese.

Nos anos 90, cerca de $90 \%$ dos coreanos vivem direta ou indiretamente ligados ao comércio de roupas. São 40.000 coreanos e seus descendentes vivem em território brasileiro, sendo que $96.84 \%$ moram na cidade de São Paulo. Veja o gráfico que representa o perfil de profissões dos coreanos no Brasil.

GRÁFICO 1

Profissões dos Coreanos no Brasil -1989

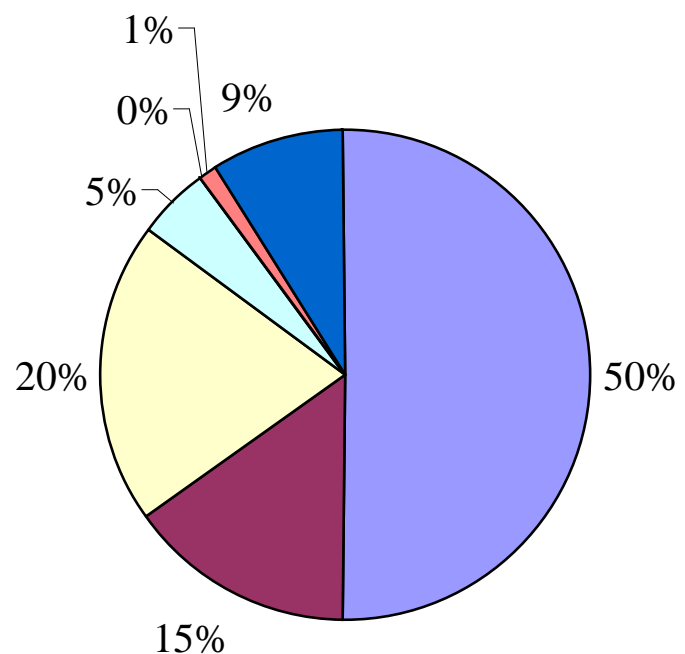

atacadista de roupa

$\square$ varejistas de roupa

$\square$ confeccionista de vestuário

$\square$ vendedores de confecção para atacado/ varejo

agricultores

$\square$ profissões liberais

outros

Fonte: Associação Brasileira dos Coreanos - 1989, in: CHOI (1990). Org.: Sueli de Castro Gomes.

O início desse processo, como registra CHOI, ocorre dessa forma:

"Muitos começaram vendendo mercadorias coreanas ou adquiridas durante a viagem. Para tanto, iam de casa em casa como vendedoras ambulantes (principalmente as mulheres). Ainda que inexperientes, vendiam com 
facilidade, pois os produtos estrangeiros tinham boa aceitação no mercado. A atividade excedeu a todas as expectativas.”... “Pouco a pouco, os coreanos iniciaram-se em uma outra atividade: a fabricação de roupas, auxiliados pelo emprego de mão-de-obra barata de seus conterrâneos, conseguiram expandir rapidamente seus negócios.” (p.95)

A autora segue o relato desse processo:

"Soo San Kin foi a primeira pessoa que teve a idéia de montar uma confecção, ao perceber a falta de mercadoria que havia para vender. Depois de pesquisar modelos e cores do agrado dos brasileiro, suas roupas, conjuntos e cobertores, utilizam-se apenas de duas ou de três máquinas de costura. Trabalhavam em seus próprios apartamentos. Como não dispunham de maiores recursos, colocavam o tecido no chão e cortavam com a tesoura, de forma ainda bem rudimentar, diferente do alto grau de sofisticação das o confecções atuais.”... “A grande demanda obrigou-os ao emprego de mão de obra complementar, composta por conterrâneos desprovidos de capital. Nesta época, ninguém imaginava que essa atividades tornar-se-iam a base da sobrevivência dos coreanos em São Paulo até hoje.” (p. 95 - 96)

$\mathrm{Na}$ década de setenta, chegam imigrantes com capital para estabelecerem a sua própria confecção. Os que vinham sem capital, faziam empréstimo ou trabalhavam de empregados de seus conterrâneos. Essa atividade se concentrou principalmente no Bom Retiro e no Brás. Em meados de 1980, a atividade era considerada de fácil acesso, pois não exigia muito capital.

“Nessa atividade loja-confecção muitos coreanos obtiveram lucros razoáveis. Entretanto, em pouco tempo o mercado ficou saturado pelo grande número dos que se dedicavam à atividade.” (p. 105)

A disputa pelo mercado era acirrada, mas não atingia diretamente aos coreanos. Pois há uma especialização do mercado, na medida em que trabalham em segmentos diferentes: os japoneses se especializaram no ramo de roupas infantis, israelitas mantinham fábricas e lojas de tecidos, e assim por diante.

Algumas estratégias foram usadas para o rápido crescimento dessa atividade, como: "a ampliação do prazo dado pelos confeccionistas ou atacadistas para a venda, que passou a ser 60 a 90 dias" (p. 105); investir o mínimo em propaganda; a prática do 
vale, que depois será trocado por um cheque, evitando os roubos e testando os modelos das confecções e suas vendas; sempre atentos a indústria da moda e por fim destacando um dos ingredientes fundamentais desse crescimento - as relações de trabalho. " $O$ fato dos coreanos colocar suas roupas à venda por preços menores despertou desconfiança dos comerciantes já estabelecidos. Dizia um comerciante local: 'Entre eles, não há sábado, domingo ou feriado. Da avó ao neto de três anos, todos trabalham em regime absurdo. São autênticos senhores feudais, construindo castelos fantasmas e provocando desequilíbrio seríssimo em nosso comércio"”(p. 107). A autora deixa de fazer uma análise mais aprofundada dessas relações de trabalho, destacando as diferenças culturais e seus valores, sobrepondo a discriminação e o estigma. Preferimos fazer uma outra discussão sobre essas relações de trabalho, que seguem nos capítulos seguintes. Essas relações de trabalho, basicamente familiar e, também, no primeiro momento apoiados na exploração do conterrâneo clandestino e, atualmente, na clandestinidade dos bolivianos, foram um dos mecanismos de crescimento dessa indústria de confecções no Brás e bom Retiro. Como afirma Romeu Tuma, são relações de trabalho que utilizam”... o medo dos ilegais de serem expulsos para submetê-los a um sistema de trabalho escravo nas oficinas ocultas da chamada Vila coreana” (E.S.P.-18.03.01), ou então como será tratado na pesquisa de SILVA (1997). Até 1982, havia cerca de 12.000 $\operatorname{coreanos}^{18}$ vivendo na clandestinidade, nesse ano é dado a anistia, entretanto simultaneamente havia o ingresso de milhares de bolivianos ilegais, movidos pelo mercado dinâmico no Brasil e as péssimas condições sócio-econômicas na Bolívia, eles seguiam a rota dos coreanos, que entravam pelas fronteiras da Bolívia. Essa forma de trabalho é que permitirá os baixos custos das confecções e assim um crescimento rápido dessas confecções. Segundo CHOI (1991):

"Os confeccionistas costumam obter uma margem de lucro entre 50 a 100\%, enquanto os intermediários atacadistas, ficam com algo em torno de 20 a $25 \% ” .(p .108)$

O sonho da ascensão social alimentou essa expansão como refere CHOI. Enfim, com sucessos e fracassos eles foram ocupando as ruas do Brás. Agitando o seu mercado imobiliário. Muitos, insatisfeitos com o preço dos aluguéis cobrados, estão entrando no setor imobiliário e construindo shoppings como - Shopping Center Luz (localizado na

\footnotetext{
${ }^{18}$ Fonte: Jornal Dong-a in CHOI (1991).
} 
antiga rodoviária de São Paulo) e outros menores que se seguiram. O Brás, Pari e a Moóca continuam como zona de operações no mundo das confecções.

Vejamos alguns dados, que podem dimensionar o que são esses shoppings, e a sua importância. Em 1983 é inaugurado o Fashion Shopping Brás, depois em 1988 o Fashion Center Luz, depois, o Polo Moda, Brás Center, Shopping Box (1993). (Veja o mapa e a tabela com o número de lojas). São shoppings atacadistas, isto é, a compra no mínimo deve ser de seis peças. Não é preciso apresentar o CGC e nem a nota fiscal da empresa para efetuar a compra. Essas condições atraem as "sacoleiras", nome popular dado as revendedoras da moda, de todo o país:

"No Brás Center, a grande maioria vem do Rio Grande do Sul, Santa Catarina e interior de São Paulo". "Na Polo Moda, $60 \%$ dos visitantes são 'sacoleiras'que compram roupas para vender de maneira informal (porta em porta ou em uma loja improvisada dentro de casa). No Fashion Center Luz, elas são 80\% do público, ...”(F.S.P. 15.08.93).

Esses shoppings, para atrair maior clientela, oferecem uma estrutura para as pessoas que vêm de fora da cidade, como: transporte gratuito que passa pela rodoviária, alguns hotéis, guarda volumes, banheiros com chuveiro, áreas de descanso e carrinhos para transportar as compras no shopping, entre outros. Além dos shoppings, continuam as lojas de rua, que comercializam as confecções. Todos esse comércio que congrega confecção - loja no setor de vestuários produzem uma enorme quantidade de rejeitos retalhos e resíduos. Esses rejeitos são os tecidos com defeito ou "fora da moda", a peça com defeito, a sobra dessas peças depois do corte, que se tornam mercadorias e novamente entram no circuito, como veremos no próximo capítulo.

O importante nesse momento é perceber primeiro o porquê da localização do comércio de retalhos e resíduos nas ruas do Brás, sua presença é intersticial, inicialmente, às fábricas de têxteis e, depois, em um segundo momento, às indústrias das confecções. Essa localização é beneficiada pelo acesso fácil, que as ferrovias e, depois, o metrô permitem, além do que, acrescida pelos fluxos migratórios que se seguem, buscando novas formas de inserção. 
Fonte: Folha de São Paulo, 15.08.1993. Caderno TUDO.

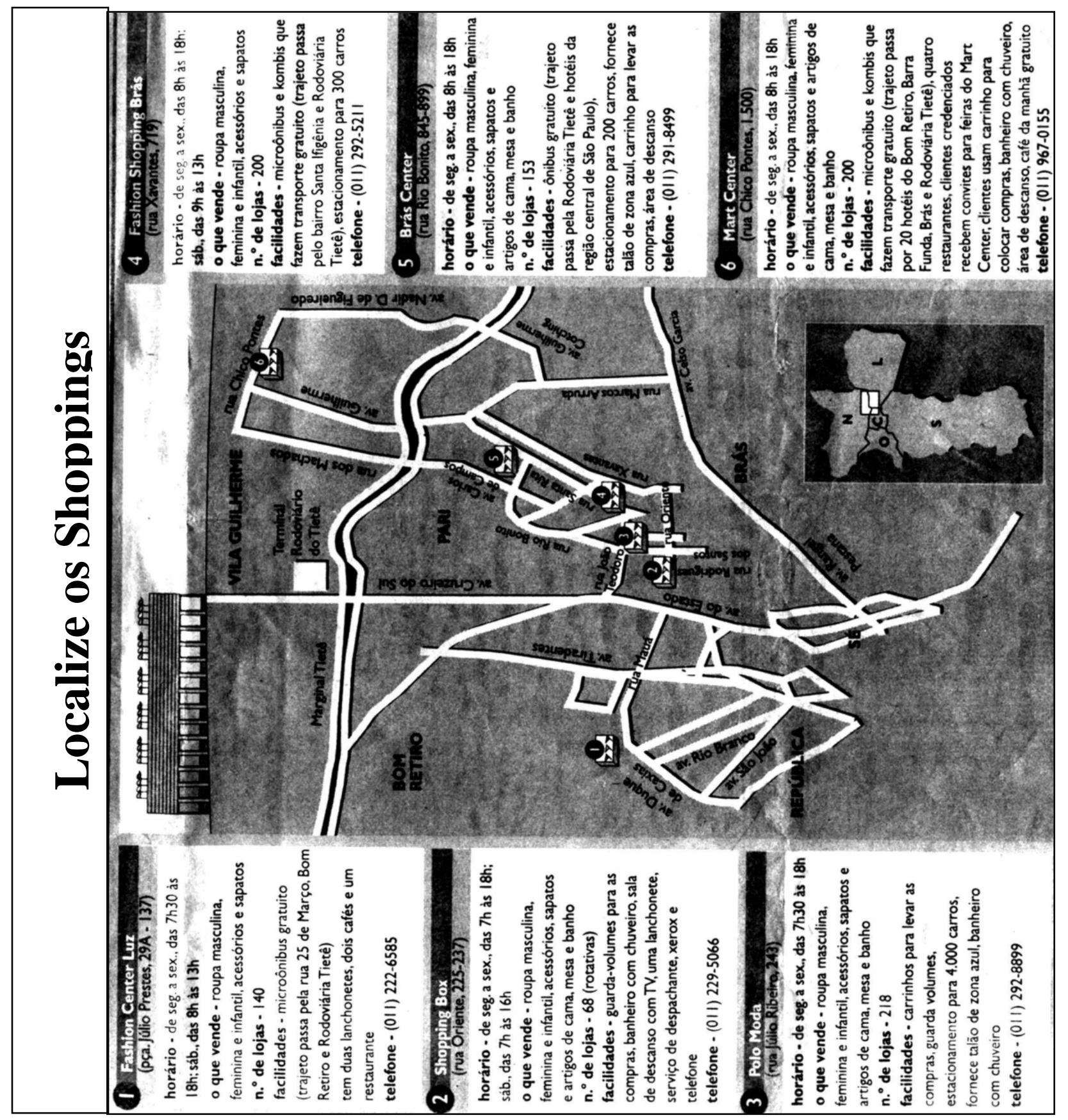

Outro aspecto, que destacamos, é a transformação que o bairro do Brás sofre ao longo do tempo. Essas modificação estão relacionadas com o crescimento da cidade e da metrópole sob o processo de modernização e a racionalização do capital, para a sua ampliação. Hoje, o bairro do Brás está interligado com várias partes do território nacional. Essa enorme quantidade de ônibus trazendo "sacoleiras" de várias partes do 
país, carregando mercadorias do Brás para o restante do país, concretizam uma malha, uma rede de mercadorias e pessoas.

Encontramos na rede da Internet, um site - www.lojasdobrás.com.br - que traz diversas informações para as sacoleiras. Além das diversas lojas e outros links, entre eles aparecem duas lojas de tecidos, localizados na área de estudo, encontramos outras informações como a história do bairro, bem como um mapa indicando a sua localização e o mapa de suas ruas. O mapa de sua localização vai representar um Brás de fácil acesso para quem chega na Grande São Paulo e, assim, a facilidade de realizar compras, para os sacoleiros. Essa forma de representação, que segue os interesses do capital para o escoamento da mercadoria, não segue a escala, traz uma distorção cartográfica. É muito comum encontrarmos tal representação no setor imobiliário, como está sendo estudado por Gisele Girardi. ${ }^{19}$ (Veja o mapa anexo). Esta página, também, traz os endereços das empresas de ônibus, localizados nos diversos estados brasileiros, que oferecem excursões para o Brás, transportando os sacoleiros. Essa informação revela os fluxos e as conexões entre o Brás e os diversos pontos do espaço nacional, trazendo esse elemento do processo de modernização.

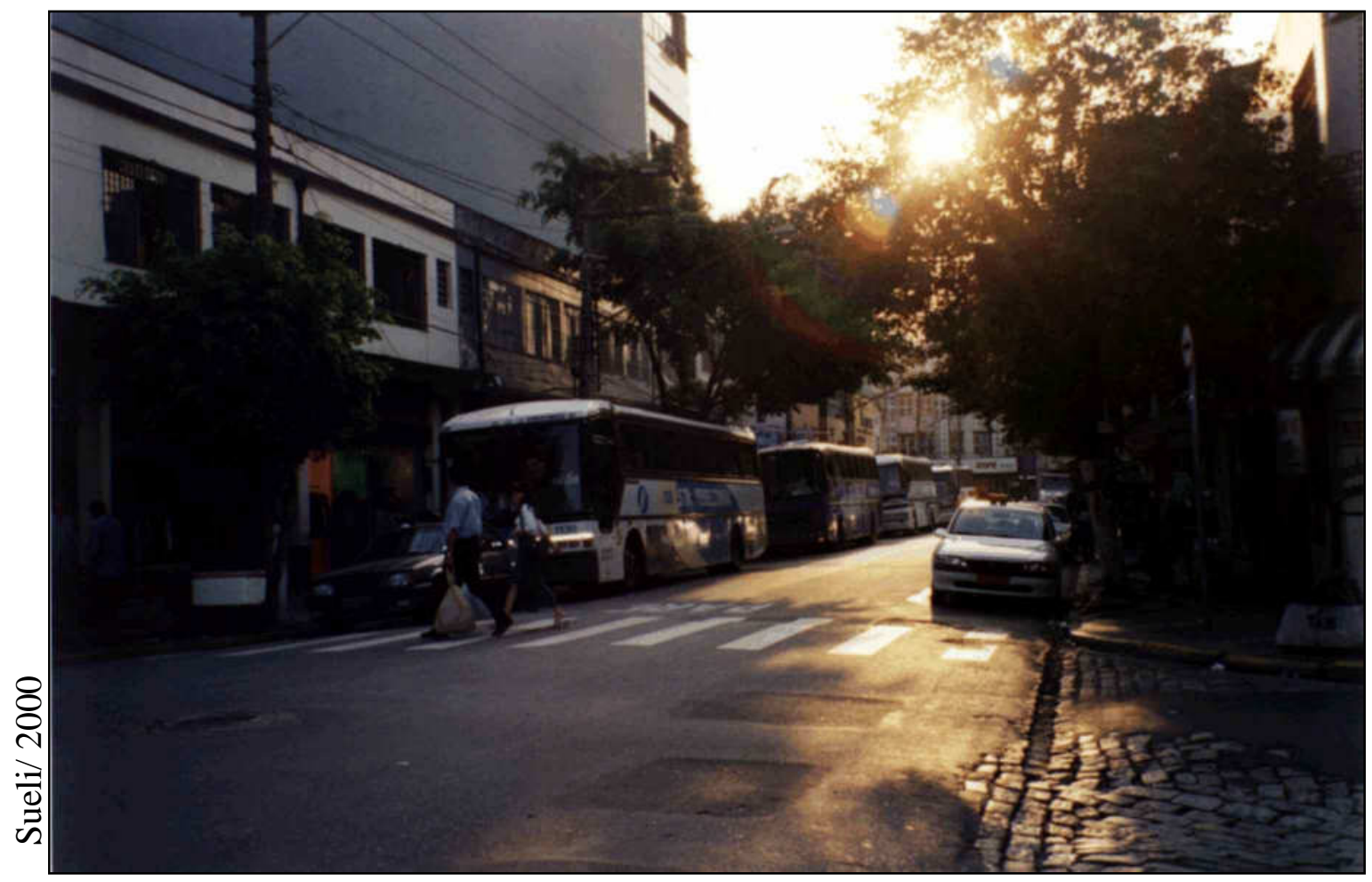

Foto 25: Estacionamento das sacoleiras no Brás.

\footnotetext{
${ }^{19}$ Mesa redonda no " 6 ' Encontro Nacional de prática de Ensino de Geografia" - 14 a 18.02.2001.
} 
Nessa rede, o Brás é um "nó", um ponto de apoio. Há uma nova configuração espacial, nas transformações que o bairro passou. Esse "nó" ou território "local" é o suporte na qual a rede pode se apoiar. A modernidade ${ }^{20}$ trouxe a racionalidade do espaço, transformando esses em vértices, arestas, linhas, nós, aglomerados. A rede de migrantes e a rede do comércio de confecções ou comércio de retalhos são redes que se superpõem e têm o seu ordenamento, formam uma malha de homens e mercadorias ou uma malha de múltiplos territórios. HAESBAERT (1995) cita DEMATTEIS (1992) que define a cidade como:

“... 'um conjunto de nós pertencentes a diferentes redes', 'um conjunto de sujeitos fisicamente coexistentes, mas que pertencem a redes de organização diferentes e cujos os interesses podem divergir à escala local, (...) Assim o espaço físico de cada cidade seria a sede de vários 'nós' pertencendo a sistemas diferentes, cada um com forma de enraizamento local (relações 'verticais') distintas'.” (APUD HAESBAERT, 1994: 182).

Para DEMATTEIS, a cidade ainda permanece um mercado unitário de trabalho e de habitação. Entretanto, nos interessa a definição de nó:

“... 'unidade físico-espacial', um sistema ambiental-local dotado de sua própria coesão interna, graças à qual ele é capaz de participar de uma coesão mais ampla da rede." ( APUD HAESBAERT,1994: 182).

Para entendermos o Brás, que deixou de ser um bairro e passou a ser fragmentos ou um nó, procuramos ler trabalhos que tratassem desse bairro-território como a pesquisa de MARTIN (1984) e ANDRADE (1994), ANDRADE (2000), SEABRA (2000) e de MUMFORD (1969).

O Bairro é formado por relações de vizinhança que constróem e dão significado aos lugares. Para Lewis Mumford considerar as relações de vizinhança para o planejamento urbano é essencial - "El barrio es un hecho social; existe en forma incipiente aun cuando no esté articulado debidamente en el plano de la ciudad no proporcione las instituciones que en la ciudad Ni proporcione las instituciones que en la actualidade necesita la comunidad doméstica." Podemos aprofundar esse conceito quando pensamos também em um recorte étnico e sócio-econômico na delimitação

20 BERMAN, Marshall. 1987. 
deste espaço. Na medida que houve um avanço do capital na reprodução do espaço urbano o recorte sócio-econômico ganha maior evidência que o recorte étnico, mas isso não significa que ele desaparece, pois mudam se as etnias conforme mudam os fluxos migratórios e esses são alterados de acordo com as exigências do capital. Essas relações de vizinhança, que se estabelecem no bairro, são denominadas nos estudos migratórios pelos sociólogos de redes sociais. Esses conceitos se aproximam muito e se cruzam entre um estudo de migração e bairro. Para entendermos melhor essa reflexão, vejamos o caso dos bairros de São Paulo. A partir de estudos dos bairros Além-Tietê a autora faz a seguinte observação:

“Assim, a temática da cidade e seus bairros precisa ser enfocada como circunstância do processo de urbanização cujo sentido é o de 'separar e mobilizar', para integrar às cadeias de equivalência, ou aos circuitos monetários, relações, produtos e coisas. A metrópole não está dada. A metrópole vai ganhando realidade como síntese de um gigantesco processo mobilizador e concentrador, que produz uma outra espacialidade do urbano”. (SEABRA, 2000: 12)

Para entendermos a atual configuração do Brás é necessário inseri-lo no processo de metropolização, revelando-o como um lugar da reprodução do capital.

Neste capítulo, estudamos o Brás desde o início desse século, recebendo um grande fluxo de migração estrangeira (europeus e asiáticos) atraídos e incentivados pelas frentes de trabalho e as atividades econômicas que exigiam este exército de reserva, consolidando o bairro. Em um momento posterior, há uma mudança na economia e na política migratória, em que o migrante estrangeiro é substituído pelo nacional, e estes últimos recriaram os bairros ou formaram novos bairros no processo de metropolização.

O bairro do Brás, enquanto espaço das relações de vizinhança já não existe mais. Ele sofre um processo de deterioração como foi estudado por MARTIN ou de dissolução como afirma ANDRADE, apoiada nos estudos de LEFEBVRE. A autora atribui essa dissolução dos laços sociais a elementos como: o abandono dos imigrantes enriquecidos, à ascensão e ao declínio de empresas, à expulsão dos trabalhadores que iam para a periferia, à expulsão dos moradores pelas fábricas que se expandiam. 
Atualmente, diante da racionalidade que a modernidade impõem não o vemos mais como um bairro, mas um espaço fragmentado, que ao mesmo tempo é o nó da rede de mercadorias e pessoas, que possibilitam a ampliação do capital. 


\title{
2. O COMÉRCIO DE RETALHOS COMO ESTRATÉGIA DE INSERÇÃO
}

\author{
A moça rica só anda, \\ Esticada e na panca, \\ Só usa tanga Duloren, \\ De preferência, cor branca, \\ E a coitada da pobre, \\ Usa tanga da Sulanca. \\ (fragmento do cordel "O Rico e o Pobre - \\ a diferença entre os dois" de \\ Isaura de Melo Souza -Panelas - PE)
}

O comércio de retalhos e resíduos têxteis está localizado nas ruas do Brás, antigo bairro industrial e operário da cidade de São Paulo. Esse bairro, atualmente, caracterizase pela grande concentração de indústrias e lojas de confecções, que vendem no atacado e no varejo para as "sacoleiras" da metrópole e de todas as partes do Brasil.

O comércio de retalhos, criado pelo grupo de migrantes nordestinos, consiste em adquirir das indústrias de confecção do Brás e têxtil, o seu rejeito e comercializá-lo. As peças maiores são chamadas de retalhos, e as menores, de resíduos. Os retalhos podem ser bobinas inteiras de tecidos com defeitos, ou com a cor fora de moda; enquanto os resíduos são os tecidos que podem já ter sido usados nas confecções e tornam-se sobras. O comércio de retalhos, que acontece há, aproximadamente, 40 anos, vai nascer nos interstícios das antigas indústrias têxteis e posteriormente, se alimentar do rejeito das confecções, que fornecem diariamente toneladas de resíduos e retalhos para serem comercializadas pelos "retalheiros". Essas indústrias, no passado, estavam na maior parte concentradas no Brás, onde predomina a indústria de confecções. Hoje, a indústria têxtil encontra-se dispersa pelo interior paulista e em outros estados. Assim, essa atividade passa a envolver cada vez mais outros espaços, pois os comerciantes também compram os retalhos das indústrias de Americana, Campinas, Santos etc. e, ao mesmo tempo, vendem para Goiás, Minas Gerais, Rio Grande do Sul e, principalmente, Pernambuco.

Uma parte desses retalhos e rejeitos é comprada por costureiras da Grande São Paulo e até mesmo por "sacoleiras", sendo que a maior parte dessa mercadoria é 
enviada para Santa Cruz do Capibaribe - cidade do interior pernambucano, que constitui um pólo de confecções de "sulanca". São vestuários de qualidade considerada inferior, consumidos, predominantemente, por uma população de baixa renda. Esse comércio acaba se tornando um exemplo da interdependência econômica entre as regiões Nordeste e Centro-Sul tratada por OLIVEIRA (1981) e SINGER (1974) em seus estudos. O nordestino de menor poder de consumo, passa a ser consumidor do "lixo", do rejeito das confecções do Centro-Sul.

Grande parcela das pessoas que trabalham nessa atividade é constituída de migrantes nordestinos. Os primeiros migrantes que iniciaram o comércio de retalhos chegaram em São Paulo por volta dos anos 60. Podemos dividi-los pela origem: o primeiro grupo está ligado à família do Sr. Otávio, apelido Dudu, da cidade de Ibirajuba e outras cidades do estado de Pernambuco; outro grupo, que tem outra característica, é formado por migrantes pernambucanos de Santa Cruz do Capibaribe e cidades circunvizinhas. Esse último grupo de migrantes surgiu seguindo o fluxo desse comércio, pois todos os dias saíam caminhões levando toneladas de resíduos e retalhos, conforme vemos na foto abaixo, para Santa Cruz do Capibaribe e no retorno, também, serviam de transporte para o migrante. Conforme depoimentos, "cada caminhão de tecido trazia 5 ou 6 ". O terceiro grupo, que tem uma dimensão menor que o grupo de pernambucanos, formou-se a partir da família do Sr. Moacir de Iguatu, Ceará. Dessa maneira, inicia-se nossa teia de investigações.

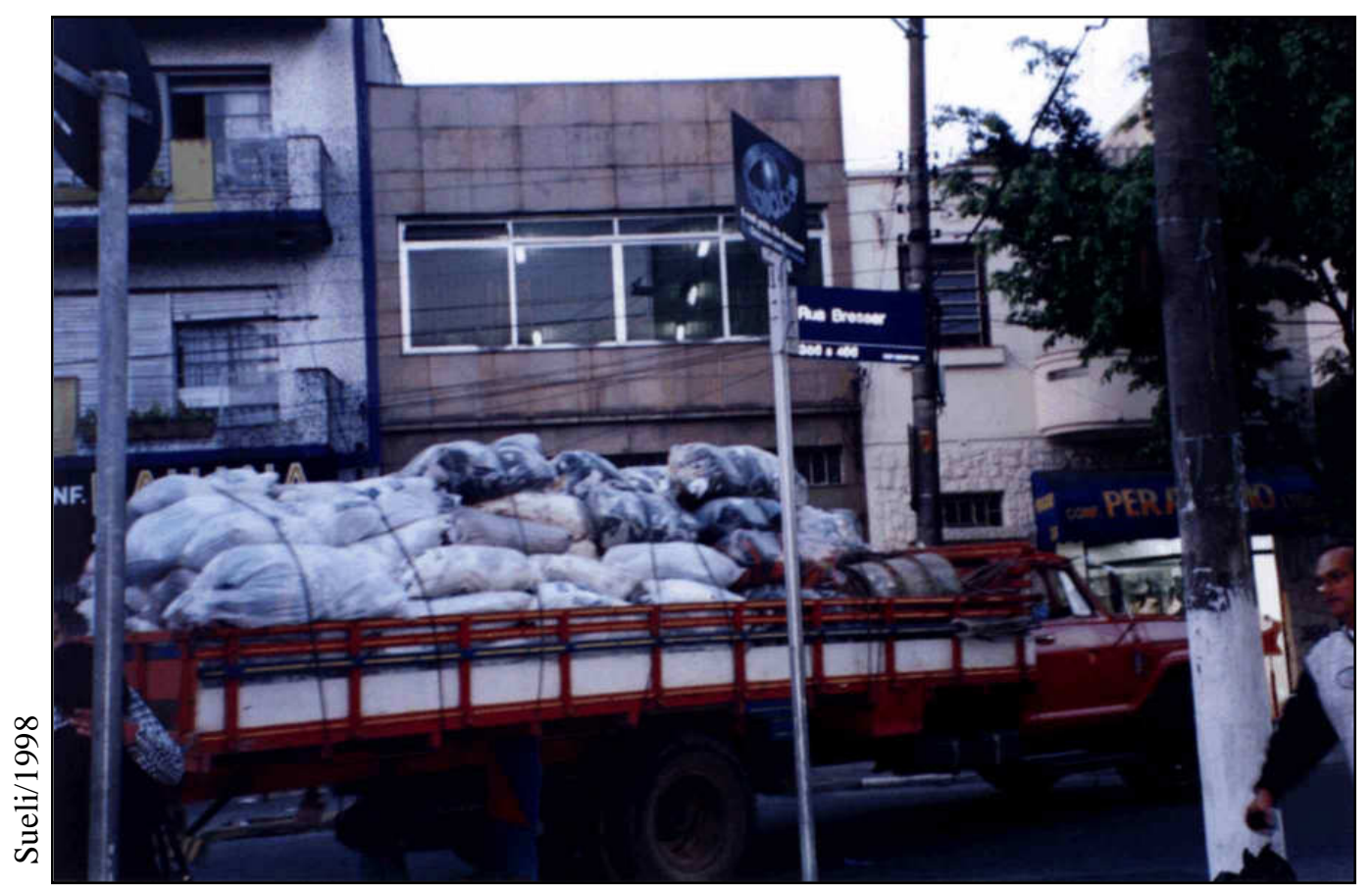

Foto 26: Os caminhões que transportam, diariamente, toneladas de resíduos, circulam nas ruas do Brás. 


\subsection{A formação histórica do comércio de retalhos e o grupo de migrantes}

A combinação de vários elementos como a migração, a ferrovia, posteriormente, as rodovias, a indústria têxtil, a indústria de confecções e a ampliação de um mercado consumidor de baixa renda originam o comércio de retalhos e resíduos

Como já tratamos, o bairro do Brás foi um pólo de atração da Grande Imigração, no início do século XX. Esses migrantes serviram de mão-de-obra operária nas indústria, entre elas, a têxtil. Os grupos mais significativos foram os italianos, portugueses e espanhóis. Porém, em menor número vieram os libaneses, turcos, judeus e sírios, que se especializaram no setor comercial. Estes povos trariam, com eles, a tradição do comércio de armarinhos, roupas, tecidos. As suas lojas localizavam-se, no passado, desde a antiga "Porteira do Brás" até a Igreja Matriz (REALE, 1982 e VILLAÇA, 1978). Outros contingentes de migrantes vieram, posteriormente, ocupar o bairro, com maior intensidade. Na década de 1940, ou seja, os nordestinos e, mais recentemente, os coreanos e os bolivianos, sendo os primeiros os proprietários das confecções e os últimos, trabalhadores nas oficinas de costura.

O crescimento urbano acelerado transformou o bairro industrial em comercial, as indústrias tradicionais, principalmente têxteis, vão gradativamente desaparecendo, enquanto as indústrias de confecções se expandem.

A urbanização crescente de São Paulo vai transformando o Brás em área central, servida por várias vias de circulação como a Av. Celso Garcia e a ferrovia, a Radial Leste e o Metrô (Veja o Mapa 2 da cidade de São Paulo e a localização do Brás, no capítulo anterior). A terciarização vai dominando o espaço do Brás, principalmente com artigos têxteis, como o vestuário, cujas lojas, além de vender no varejo e no atacado, são também, indústrias de confecções.

Na pesquisa de Glauce Campelo A atividade de confecções e a produção do espaço em Santa Cruz do Capibaribe - PE, há o registro dos primeiros indícios da comercialização entre Santa Cruz do Capibaribe e São Paulo. Desde os anos 30, sabiase do uso de retalhos de tecidos na confecção. No primeiro momento, as confecções buscavam os retalhos em Recife e a partir dos anos 60, em São Paulo. Enquanto o Brás se torna uma área comercial, no município de Santa Cruz do Capibaribe em 
Pernambuco vai se formando a concentração de oficinas de confecções ${ }^{21}$, especializadas na industrialização de retalhos para produção de roupas. Vejamos:

"Todavia, vale ressaltar a importância dos anos sessenta para o impulso que a atividade tomou, quando se partiu para comprar retalhos em São Paulo. Esta é a fase de integração do espaço nacional através da abertura das estradas, lançando os caminhoneiros ao transporte de mercadorias para as localidades mais distantes. Inicia-se aí o intercâmbio comercial entre Santa Cruz do Capibaribe e a região Sudeste do país. Começam a chegar toneladas de retalhos para a cidade, ensejando a mobilização crescente de pessoas na atividade de produção de comercialização de confecções. Quase todos os feirantes desta década viajaram a São Paulo para comprar retalhos e revendêlos em Santa Cruz do Capiberibe. A compra de retalhos e peças de tecidos em grande quantidade e a baixo custo, promoveu a acumulação do capital para estas empresas e viabilizou o estabelecimento de armazéns para a venda do produto. A grande quantidade de matéria-prima que chegava, intensificou a fabricação da confecção de segunda categoria, ...” (CAMPELO, 1984: 73-74).

Os depoimentos citados na obra de CAMPELO explicitam o crescimento dessa atividade no município, nos anos 60, entretanto a consolidação ocorre a partir dos anos 70.

"Mas somente em 1966 é que comecei a comprar retalhos nas fábricas de Recife (Paulista, Othon e Camaragibe). Logo depois comecei a comprar também em São Paulo. De início no caminhão dos outros, depois comprei um 'Jipe' e depois um caminhão...Quando comecei neste trabalho foi como ajudante de motorista nos caminhões dos outros. Eu tinha um dinheirinho e quando cheguei em São Paulo comprei tudo de pano" (CAMPELO, 1984: 78).

Embora já fosse comercializado no Nordeste, os resíduos não eram vendidos pelas indústrias de confecção. De acordo com uma antiga moradora do Brás -descendente de italianos e retalheira-, até 1960, não se dava importância a essa mercadoria. Assim, os resíduos eram jogados no lixo ou amontoado nas esquinas. Fim do expediente, os indivíduos, com carrinhos recolhiam o material, tal qual fazem, na atualidade, os

\footnotetext{
${ }^{21}$ No dicionário Aurélio encontramos a seguinte definição para confecção: 1. Ato ou efeito de confeccionar 2. Roupa Feita, ou confeccionada em fábrica, que se adquire pronta.
} 
catadores de papel e sucatas. Dessa maneira, a matéria-prima saí de graça, demarcando um período em que os comerciantes de resíduos ganharam muito dinheiro com a atividade. Encontramos esse tema tratado na pesquisa de LEGASPE (1996).

Ao mesmo tempo, o domínio dos coreanos da indústria de confecções demarcou um novo período. Eles, conforme CHOI (1991), trabalhavam intensamente e modernizaram a produção, tal fato propiciou o aumento das confecções e por conseguinte, o aumento do volume de rejeitos, ou seja, dos resíduos. Em geral, essas lojas de confecções têm como balconistas, os nordestinos. Com o crescimento do comércio amplia-se a inserção de nordestinos, mobilizados para este trabalho, são balconistas, vigias e outras funções dessa atividade. Soma-se a isso, também, o trabalhador por-conta-própria, principalmente, no comércio informal, como os camelôs e serviços, voltados, também, para a comunidade nordestina. Nesse processo, em que os nordestinos buscam a sua inserção em São Paulo, ocorre a criação e o desenvolvimento do comércio de retalhos.

Enfim, existiu um conjunto de elementos que possibilitaram a criação desse comércio no Brás:

- Processo de migração, que fez com que número grande de nordestinos buscasse novas formas de inserção.

- O pólo de concentração no Brás das confecções e sua modernização acelerada pelos coreanos, criando fartas quantidades da matéria-prima - retalho, mercadoria.

- A existência prévia de um mercado no Nordeste, que após os anos 60, foi impulsionado pelas rodovias, havendo maior escoamento das mercadorias.

\subsubsection{Um pouco de sua história - início do comércio e sua evolução}

O embrião da atividade de comércio de retalhos aparece inicialmente com um pequeno grupo de espanhóis. Foram citados, nos depoimentos, alguns espanhóis que aproveitavam os retalhos das indústrias. Desse grupo, dois retornaram para a Espanha, um faleceu e outro mora na Zona Leste (Vila Ré). Os espanhóis eram o Sr. Ovídio (voltou para a Espanha); o Sr. Ricardo (morreu), o Sr. Emílio (mora na Vila Ré), o Sr. Valentim (mora na Espanha), o Sr. Sais e o Sr. Miguel. No bairro do Bom Retiro, haviam outros espanhóis que trabalhavam nessa atividade. Eles reaproveitavam o 
resíduo, rejeito, das confecções do Brás, e picotavam em máquinas. Existiam dois tipos de máquinas, as "tesourinhas" que ocasionavam muitos acidentes, em que os trabalhadores perdiam os dedos. E a "Máquina do Diabo". Assim conta um depoente:

“O Sr. Ovídio tinha a máquina de mõe e depósito.”.... “Naquele tempo havia duas máquinas que picotavam os retalhos a primeira chamada de tesourinha para fazer a estoupa (Usa o tecido cru) e a outra era a chamada "máquina do diabo"... "Porque era uma máquina perigosa, tinha uma potência". "Naquele tempo os tecidos que eram recuperados eram helanca, poliester e lã. Não existia a espuma... o outro era moído para encher colchão de acampamento”... “O patrão vendia os restos”. (Sr. Simião)

Eles vendiam esse produto como estopa, ou para fazer "enchimento" de colchão e banco de automóvel, pois por volta dos anos 50, não existia a espuma sintética. A partir da década de 60, o aproveitamento desses resíduos passou a ser feito predominantemente por um grupo de nordestinos, que no caso não picotavam, mas revendiam. Além dos resíduos, os nordestinos, também, comercializaram os retalhos, que são aproveitados por seus conterrâneos para produzir uma confecção mais popular, a chamada sulanca ${ }^{22}$. É importante destacarmos as diferentes formas de inserção dos migrantes espanhóis e nordestinos no aproveitamento do resíduo - os espanhóis fazem a transformação do resíduo em uma outra mercadoria, então ocorre o processo de industrialização, enquanto o nordestino organiza a sua circulação, criando o comércio de retalhos e resíduos, objeto desse estudo.

Por meio de entrevistas, identificamos o grupo pioneiro responsável pelo início da atividade, os pernambucanos, introduzidos pelo Sr. Dudu, depois Sr. Zuca, cunhado de "Seu Dudu". Eles começaram como sócios e depois se separaram. "Seu Osmar" e "Zé Bezerra" também foram citados como retalheiros do mesmo período ${ }^{23}$. Isto é, eles trabalhavam apenas com o resíduo. Depois, vieram os cearences, introduzidos por "Sr. Simião", que inovou na comercialização dos tecidos maiores, os retalhos. O Sr. Otávio ou Dudu, assim apelidado pelos pernambucanos, está com 82 anos. Ele nos relatou um pouco dessa história:

\footnotetext{
${ }^{22}$ Vestuário de baixa qualidade.

${ }^{23}$ Esses precursores, na sua maioria são pernambucanos e formaram uma rede social na construção do comércio.
} 
"A idéia foi dada por mim e foi dada por esse espanhol. O Espanhol foi quem disse, 'Otávio', ele era argentino, disse 'O ramo do retalho ${ }^{24} . .$. você e tal', eu tinha um restaurante, fazia... ele até,.. eu tinha um restaurante na esquina com salão e disse 'Olha, lá na Argentina esse retalho, o povo faz não sei o quê', aí, eu comprei uma parte de retalho e peguei e vendi, aí, depois, pegou a aparecer retalho o povo ofereceu, naquele tempo, todo mundo queria vender, não tinha quem comprasse, mesmo. Aí foi que surgiu as fábricas para desfiar, fazê a estopa. Aí, funcionou, funcionou, não deu muito lucro, não deu quase nada, não. Não deu prá fazê nada, eu vim arruma uma coisinha a mais, uma casinha pra morar, um cantinho prá negociar...” (Sr.Dudu)

"Quem apresentou retalho pra mim, foi Ovídio, era espanhol. Trabalhei. Não foi Ovídio..., quem me apresentou no ramo de retalho, quem me colocou no ramo do retalho, naquela época, foi Maurício. Maurício era espanhol. Já morreu, era de idade, já, tinha pratica, tinha loja de tecidos, de roupas feitas. 'Seu Otávio, vamos abrir aqui nesse ponto. Construir um ponto'. Que era o terreno ali, na Maria Joaquina, era um terreno, era um prédio de 14 metros de frente, com 40 de fundo que... [...] já tava com retalho pequeno eu trabalhava com retalho pra desfiar, pra desfiação. Eu vendia para Ovídio, vendia para o Miguel, para Ponta Grossa, também, me comprava o retalho. Naquele tempo, eles pegavam o retalho, eles moíam e vendia a lã do retalho eu comprava e enfardava e vendia para eles." (Sr. Dudu)

"Quem comprava o retalho era eu e revendia para eles [os espanhóis]. Eu comprava e revendia, entendeu como que é? Eles têm as fábricas de desfiar, e eu comprava o retalho e dali enfardava e vendia para eles. Eu fornecia à eles, naquela época. Só tinha eu. Depois apareceu mais gente, também. Negócio a gente vai começando e o povo vai vendo. Naquele tempo era eu, só eu.” (Sr. Dudu)

“Eu que fornecia para os espanhóis, era eu; pra Ovídio, pra Miguel, para outro, lá, que era irmão de Vídeo. Tinha um espanhol, aqui, na rua... morreu o ano passado, já. Tinha também uma máquina, desfiava também, aí naquele tempo fervia por aqui. Esse negócio, o negócio aqui era retalho e funcionava.” (Sr. Dudu)

\footnotetext{
${ }^{24}$ O Sr. Dudu denomina o resíduo de retalho e o retalho ele denominará de tecido, pano grande, nos seus depoimentos.
} 
O Sr. Dudu veio à São Paulo, pela primeira vez, a passeio. Ficou nos hotéis do Largo da Concórdia, no Brás; pois para ele “... era lá que ficavam os nordestinos.” Em Ibirajuba, era proprietário de três padarias e quando veio para São Paulo, veio de avião, demostrando assim um certa capitalização. Depois de um ano, retorna para São Paulo para se estabelecer, primeiro com restaurante, depois no comércio de retalhos. Também foi proprietário de outros estabelecimentos comerciais como armazém, pensão, mas sempre manteve o comércio de retalhos, como atividade principal. Naquela época, as indústrias de confecções eram da "estrangeirada" como denomina o Sr. Dudu. Vejamos em seu depoimento como era o funcionamento do comércio:

“Estrangeiros, mesmo. Estrangeirada. Espanhol, tinha loja, Judeu. Eles tinham aí o retalho, tinha prá vende, dava o telefone, ele ligava e mandavam pegá. Eles contratavam, tinha uma carga para..., cortarvam, o cara corta, todo mês 2 ou 3 mil quilos. Quando tem retalho, eles já tavam ligando "Alô, já tem retalho” e já mandavam pegar o retalho, já mandava ensacar o retalho, mandava o carro para pegar. Aí, eu, também, comecei. Eu não comecei arrastando, mas no começo mesmo, era carroça. mesmo. Aí, foi...passei a juntar, trabalhava com carroça, vendiam prá mim. Depois, comprei Kombi e butava o material.” (...) “Das lojas. Botava os empregados prá comprar. Eu tinha das lojas controlado nas lojas, prá gente pega. Vai na loja, contrata o retalho. Toda vez que (ele dá...) junto o retalho. A gente vai lá e compra o retalho." (...) "Não de caminhão, mesmo. De carrinho, já apanho muito, de carrinho. Apanha muito. Tinha os carreteiro de carrinho. Os que pegava, também, eu comprava a eles na loja, já, no depósito e tinha eu direto, também, que eu comprava. Eu tinha três Kombis, naquela época, com os empregados, (caiando) pegando material e trazendo para a minha loja. Aí, fornecia para os espanhóis.” (Sr.Dudu)

Os anos 60, esses rejeitos passam a adquirir valor comercial (preço), pois até então, essa matéria prima era encontrada gratuitamente, conforme assinalado acima. Esses resíduos são vendidos por um preço mínimo por muitas confecções ou doados para os "catadores". Às vezes, esse resíduo é doado, e, às vezes, é vendido pela indústria da confecção. Essa relação depende do tamanho do resíduo, do volume envolvido, do tamanho da própria indústria de confecção. Se for um volume irrisório, esse resíduo é desprezado pela indústria de confecção. Encontramos situações, em que o proprietário da confecção deixa esse resíduos para seus funcionários, como um incentivo. Esses 
funcionários, então, vendem, como uma complementação salarial, a chamada "caixinha". Essa forma desobriga o dono da indústria de confecção arcar com maiores salários e também estimula o funcionário a produzir mais, aumentando a quantidade de resíduos. Vejamos o depoimento do Sr. Dudu.

"Doava não. Não havia doação nenhuma. Tudo era comprado, naquele tempo era comprado. Já em 60. [...] Naquele tempo, não comprava ninguém, então quando eu peguei a comprar, aí tinha gente, aí o dono do retalho (perdeu o visto). Não dava mais a ninguém. Antigamente, aquele retalho era até dado, antes de mim, dava, butava no lixo, mas depois, eu peguei a comprar, aí depois, e eles começaram a vender, vender. Aí... [...] Não peguei nada de graça. Nada de graça chegou pra mim. Só comprava." “Era o resíduo, Bobina era peça. Dá-se o nome de resíduo, mesmo. O retalho, só. depois eu deixei o ramo do resíduo e peguei a trabalhar com o retalho porque o resíduo não dava lucro, também, deixou de dar lucro. Eles pegaram a vender muito caro na loja, vender muito caro. Eu peguei e deixei de comprar, deixei de comprar o retalho. peguei a trabalhar o retalho grande, pano grande, tecido. Ainda continua até hoje." (...) "Pegava no carrinho, Pegava no carrinho. Às veiz, trabalhava direitinho pra mim, às veiz vendiam pra mim Às veiz, aquele povo que trabalhava. Depois abria um depósito, também, e trabalhava para eles, mesmo. Porque o retalho vendia... a pessoa.... Hoje mais não, antigamente, o retalho dava a cata, catava o retalho. [Seu filho Moacir diz 'hoje, ainda cata.'] Hoje ainda tem. Muita gente vive catando retalho, compra o resíduo e do resíduo retalho e daquele retalho, vende prá colcha, roupa de mulher(buneca)." (Sr. Dudu)

O Sr. Simião montou uma loja na rua Maria Joaquina. Ele será o primeiro a vender o retalho grande, depois entraram o Sr. Otávio, depois o Sr. Ovídio, para trabalhar com o retalho. Os pernambucanos, compradores, iam buscar o tecido na rua 25 de março, então ele ia oferecer sua mercadoria lá. Depois de estabelecer os primeiros contatos no negócio, trazia esses pernambucanos que buscavam uma mercadoria mais barata para a rua Maria Joaquina. No ano que ele iniciou, em 1969, boa parte dos compradores vinham de Caruaru e Santa Cruz do Capibaribe. Em 1970, já vinham compradores de Goiás, Minas, Bahia e Paraná. Atualmente, vêm compradores, também de Santa Catarina e do Rio Grande do Sul. "O Largo da Concórdia é o centro do Mundo.” (Sr. Simião) 
O comércio de retalhos e resíduos instala-se próximo à grande concentração de indústria de confecções. Essa localização facilita o acesso à compra e à venda. Essas unidades comercias se diferenciam, no tipo de mercadoria que oferecem e na ocupação da edificação: são depósitos ${ }^{25}$, são lojas e são residências, onde apenas se separam os retalhos.

O Sr. Dudu nos descreve como era a rua Maria Joaquina, nos anos de 1960, quando instalou o primeiro depósito de resíduo e suas mudanças:

“... Espanhóis. É espanhóis da Maria Joaquina, em 1961, foi que eu (fiquei) com José Abramo. Aluguei aquele o prédio da esquina, lá, com ele na avenida Maria Joaquina, fiquei ali 28 anos, no prédio. Foram 28 anos. Aí continuei trabalhando, comprava retalho. Não tinha prédio ainda, só tinha casinha velha, tinha uma padaria na esquina, ali, que era do Sr. Pirez, aqui na esquina da Bresser com a Maria Joaquina. Tinha o Manfredo, tinha uma cada de pneu ali na Maria Joaquina, também, que foi do meu tempo, e naquela época. Eu fiquei ali na esquina da rua Maria Joaquina, alugada por “Zé Abrano”. Agora depois de Zé Abramo, eu aluguei uma casa ali naquele prédio que estavam sendo construído nessa rua primeira, Major Marcelino. Depois, só estamos aqui na rua Rio Bonito, então, da Maria Joaquina do Brás, daqui Maria Joaquina; eu tô com 40 anos." (...) “Mudou-se. Modificou muito as coisa, as coisas aqui, Não tinha...aquela rua Maria Joaquina era tudo casinha velha, rancho véio, casas, não passava nem ônibus, ali, não carro, nem nada. Aí depois pegou a melhorar..., movimentar..., asfaltaram... Não passava ônibus, não. Ali, na Maria Joaquina, no meu tempo, era esquisito. Eles jogavam malha no meio da rua. Quarenta anos, passado, isso aqui, o Brás só tinha movimento mais na Concórdia, por ali.”

Assim, a expansão do comércio de retalhos na ruas do Brás, vai acompanhar a transformação que o bairro sofre nas últimas décadas. As mudanças do estabelecimento do Sr. Dudu, pelas ruas do Brás mostrou como foi a ocupação das ruas, de acordo com a valorização dos imóveis. No início, o comércio estava concentrado na rua Maria Joaquina, depois espalhou-se por outras ruas do Brás, chegando à rua Cachoeira e se expandindo em direção ao Pari. O deslocamento deu-se pela valorização dos imóveis das áreas mais centrais em que os retalheiros mais antigos ocupam as áreas primeiras

\footnotetext{
${ }^{25}$ Existe uma diferenciação entre o conceito de depósitos e lojas, entre os retalheiros. A loja comercializa, principalmente, os retalhos, enquanto o depósito comercializa os resíduos. Ás vezes, eles são mistos.
} 
desse ramo e os mais novos, as áreas mais recentes, na busca do preço do aluguel mais acessível. Apenas três retalheiros, mais capitalizados, permaneceram na área original, outros precursores se mudaram, recuando. Os menos capitalizados procuram o entorno. Além de se estabelecerem nas áreas limítrofes, os retalheiros com pouco capital têm sua atividade nas áreas mais deterioradas, atraídos pelos baixos aluguéis. Em alguns casos, essas edificações têm dupla função, servem de local de trabalho e também de moradia.

"Lá é pra quem tem dinheiro mesmo, é mais caro o ponto-aluguel, tudo é mais caro, aqui é mais em conta". (D. Maria)

Uma parte dos atuais proprietários iniciaram e iniciam o comércio apenas comprando e revendendo os retalhos; depois eles conseguiam uma instalação própria, às vezes emprestada e sem firma registrada. Quando conseguem a própria firma, alugam um salão maior que o inicial para o depósito, como podemos verificar nos depoimentos:

"Comprando aparas menores de tecido, não tinha estabelecimento, depois aluguei um comodozinho, abaixo do nível da rua, foi aí que comecei. Fui aumentando, estabeleci uma firma, aí continuei". (Sr. Ismael).

"... depois de escolher papelão, escolhi retalho pros outros, foi indo, escolhendo, quando as condições da gente era difícil - eu também trabalhei, catando retalho pros outros... aí quando eu tava na quinta série, aí eu escolhia retalho aí meu pai foi subindo, escolhendo. Primeiro alugou um abrigo, uma casinha, um negócio de retalho, bem pequeno mesmo, do tamanho de um banheiro, né, escolhia, lá eu (...). Depois alugou um depósito na Silva Teles..." (Tania).

No período que vigorou o Plano Cruzado ${ }^{26}$ verificou-se uma explosão do número de unidades comerciais. Segundo um retalheiro, nas ruas especializadas no comércio de retalhos haviam de 20 a 30 depósitos em cada rua. Vejamos o mapeamento que fizemos das unidades comerciais nas ruas do Brás.

\footnotetext{
${ }^{26}$ O Plano cruzado (1986) foi um plano econômico criado no Governo Sarney, que estimulava o grande consumo. $\mathrm{O}$ aumento de consumo de vestuário estimula uma maior circulação da mercadoria.
} 
MAPA 4

\section{O COMÉRCIO DE RETALHOS E RESÍDUOS DO BRÁS}

335000

336000

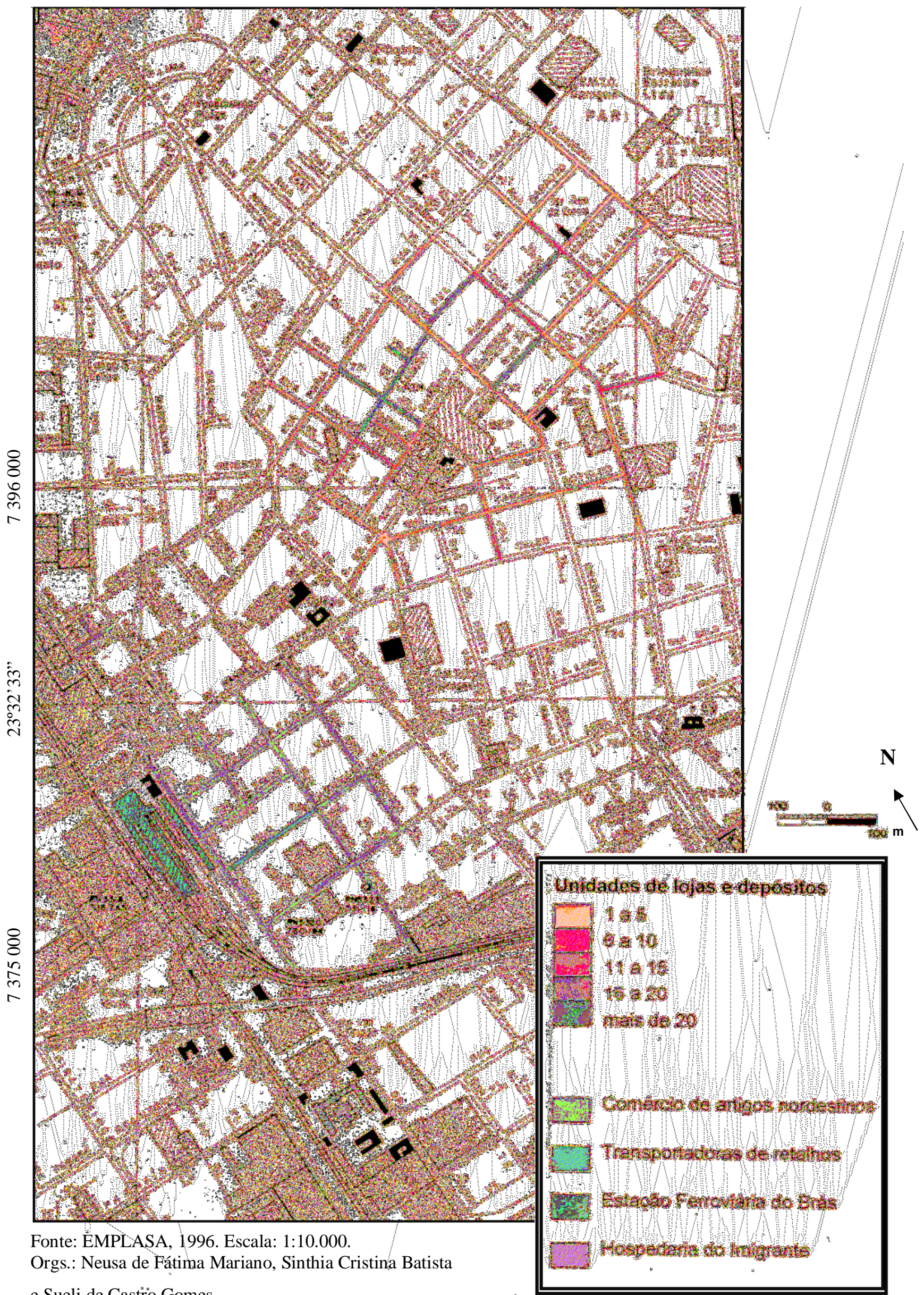

e Sueli de Castro Gomes. 
Numa primeira observação, no levantamento de campo, identificamos aproximadamente 330 unidades, entre as lojas e depósitos. Muitas vezes, a mesma unidade possui características mistas. A caminhada pelo conjunto das ruas, levou-nos a identificar a distribuição do comércio de retalhos e resíduos; grande parte dessas unidades estão concentradas nas rua Joly e rua Almirante Barroso e dali há um espraiamento em direção ao Pari, conforme o mapa. Outra dinâmica significativa é o afastamento que as unidades comerciais estão sofrendo para as áreas periféricas, pois as áreas centrais estão sendo ocupadas pelas confecções. A rua Maria Joaquina, a primeira a ser ocupada pelo comércio de resíduos e retalhos, deixa de ser a área central, e a lojas irão ocupar as ruas mais afastadas, procurando aluguéis menores. As lojas, com retalhos, na maioria ficam nas áreas mais centrais e os depósitos, na maioria, ficam nas bordas, da área representada, reforçando o seu pequeno pecúlio e a busca dos imóveis de menor valor.

No trabalho de campo, observamos que nas ruas em que esse comércio de retalhos e resíduos se localizam, outras atividades comerciais se formaram. Encontramos lojas de aviamentos, botões, zíperes e todos os artigos necessários para a costura, com as características dos retalhos e resíduos - artigos que têm uma qualidade inferior e um preço menor. Esse comércio, tem uma história semelhante ao comércio, aqui estudado, e se forma posteriormente, em razão da concentração do comércio de retalhos e resíduos. Identificando, também, migrantes que assumem essa atividade, como uma nova forma de inserção.

Outras atividades que aparecem com certa constância nessas ruas são os depósitos de lixo com carrinhos, que trabalham com diversos tipos de materiais recicláveis e uma grande quantidades de bares. Nesses bares, pudemos identificar um cardápio voltado para a comunidade nordestina como: sarapatel, mocotó,... .Esse comércio está voltado para os retalheiros e outros trabalhadores dessas ruas, bem como os comerciantes de Santa Cruz do Capibaribe, de Pernambuco, enfim os seus clientes. Encontramos na rua Almirante Barroso, ainda uma fábrica de moer o resíduo, controlado pelo filho de um dos espanhóis, permanece em razão da farta oferta de matéria-prima, e por ser próxima dos depósitos de resíduos. 


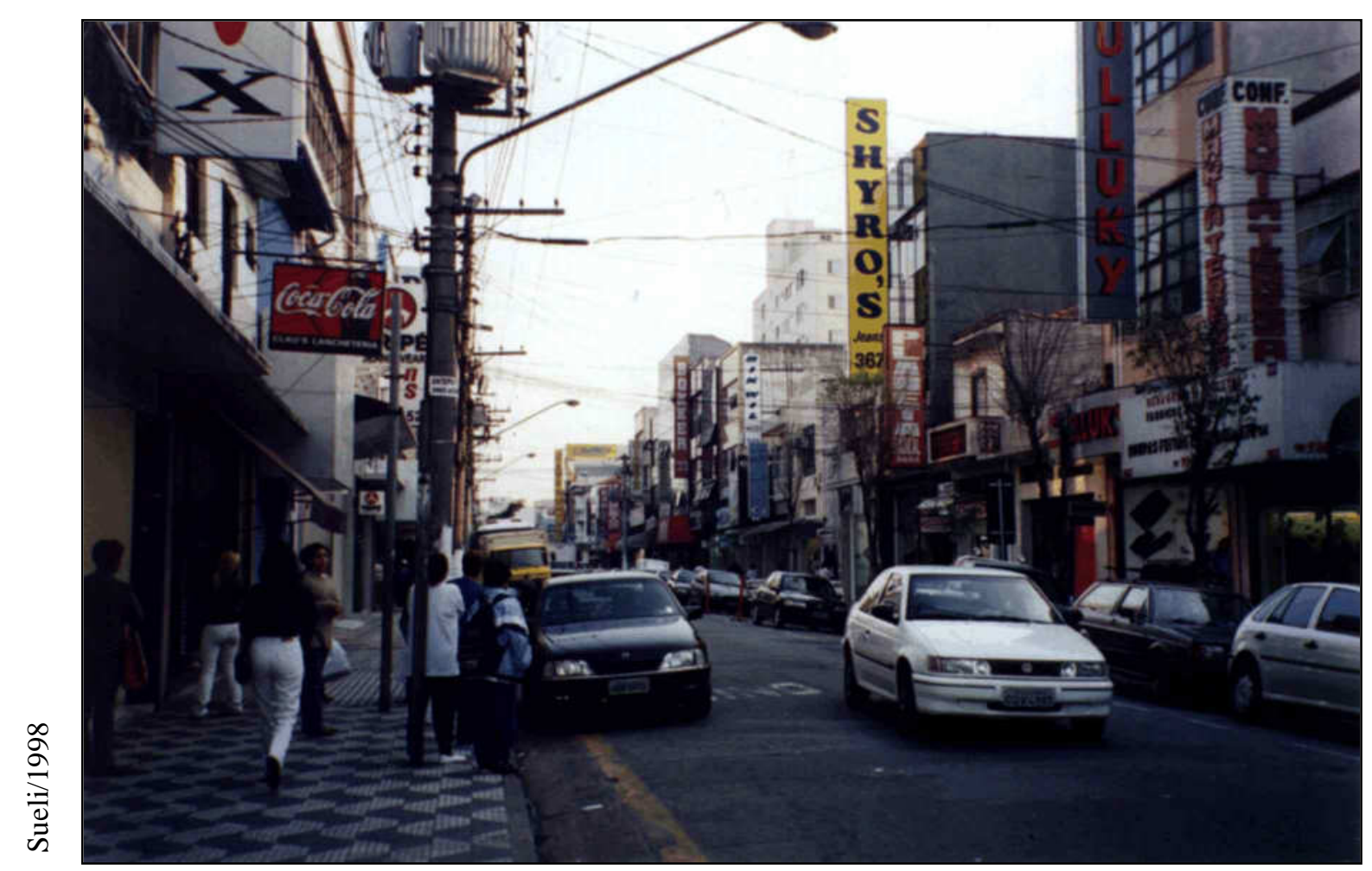

Foto 27: A atual rua Maria Joaquina é ocupada, predominantemente por confecções.

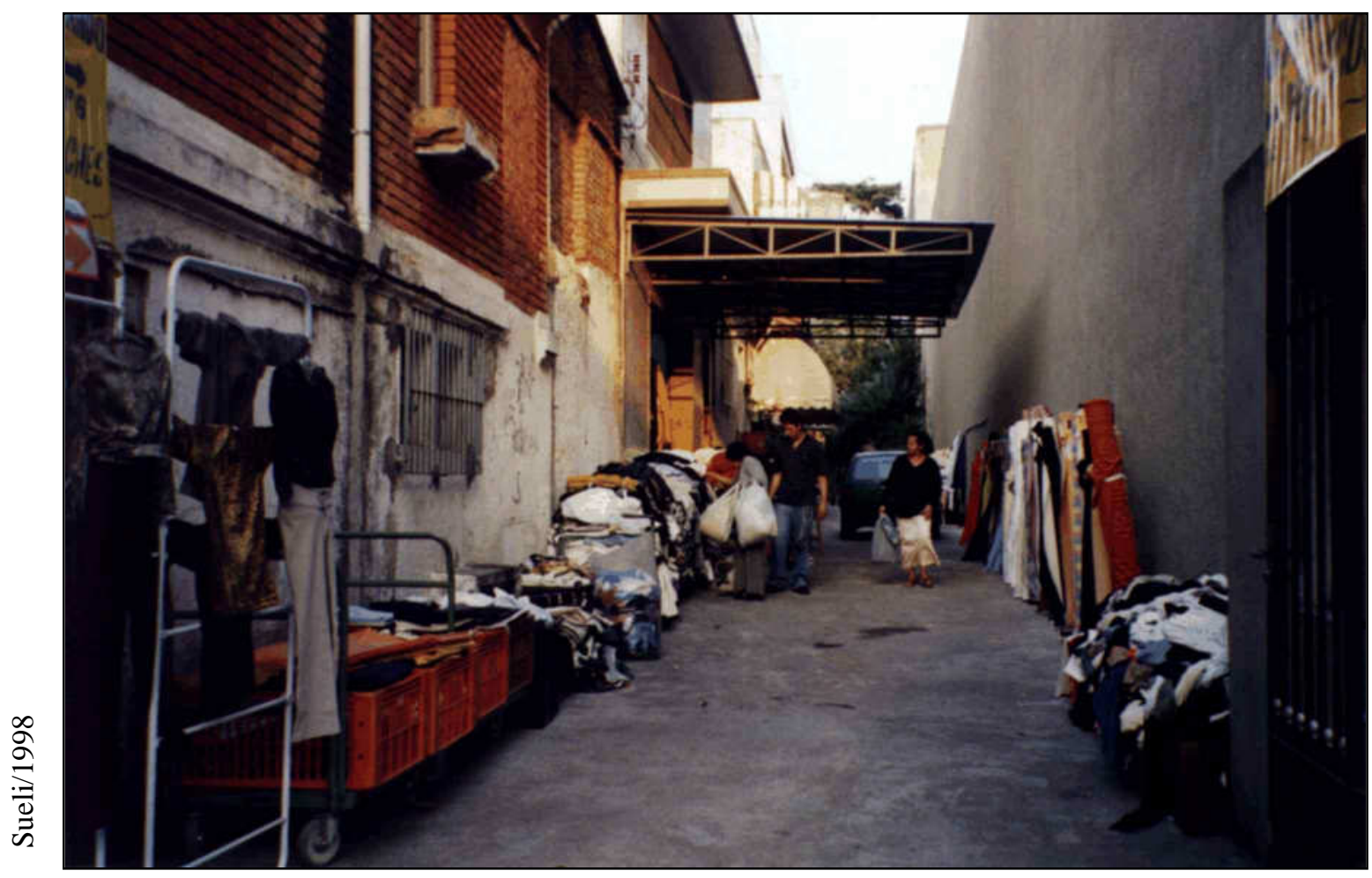

Foto 28: As antigas vilas operárias e as diferentes residências foram transformadas em lojas e depósitos. 


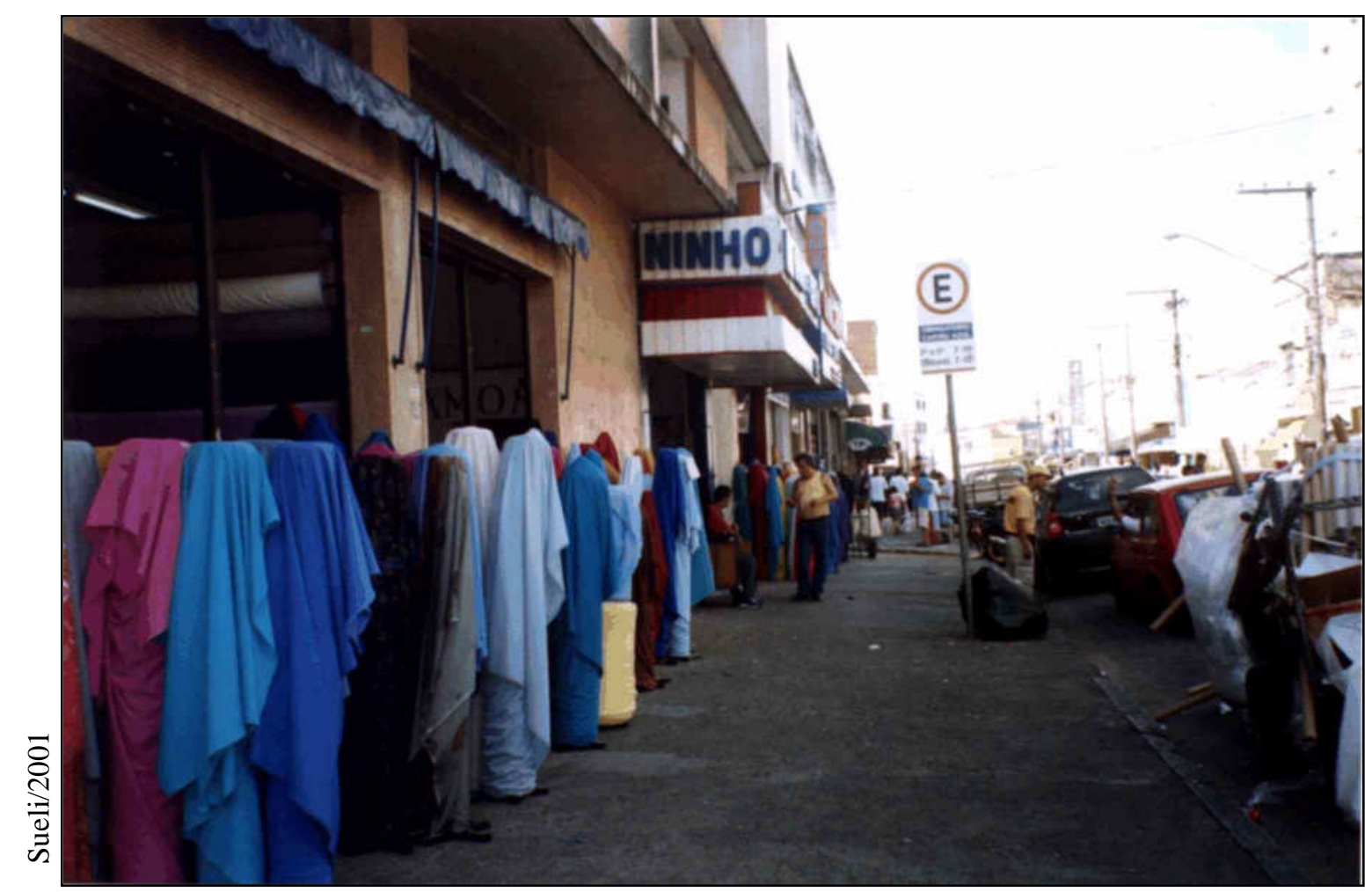

Foto 29: Rua Joly com lojas de retalhos.

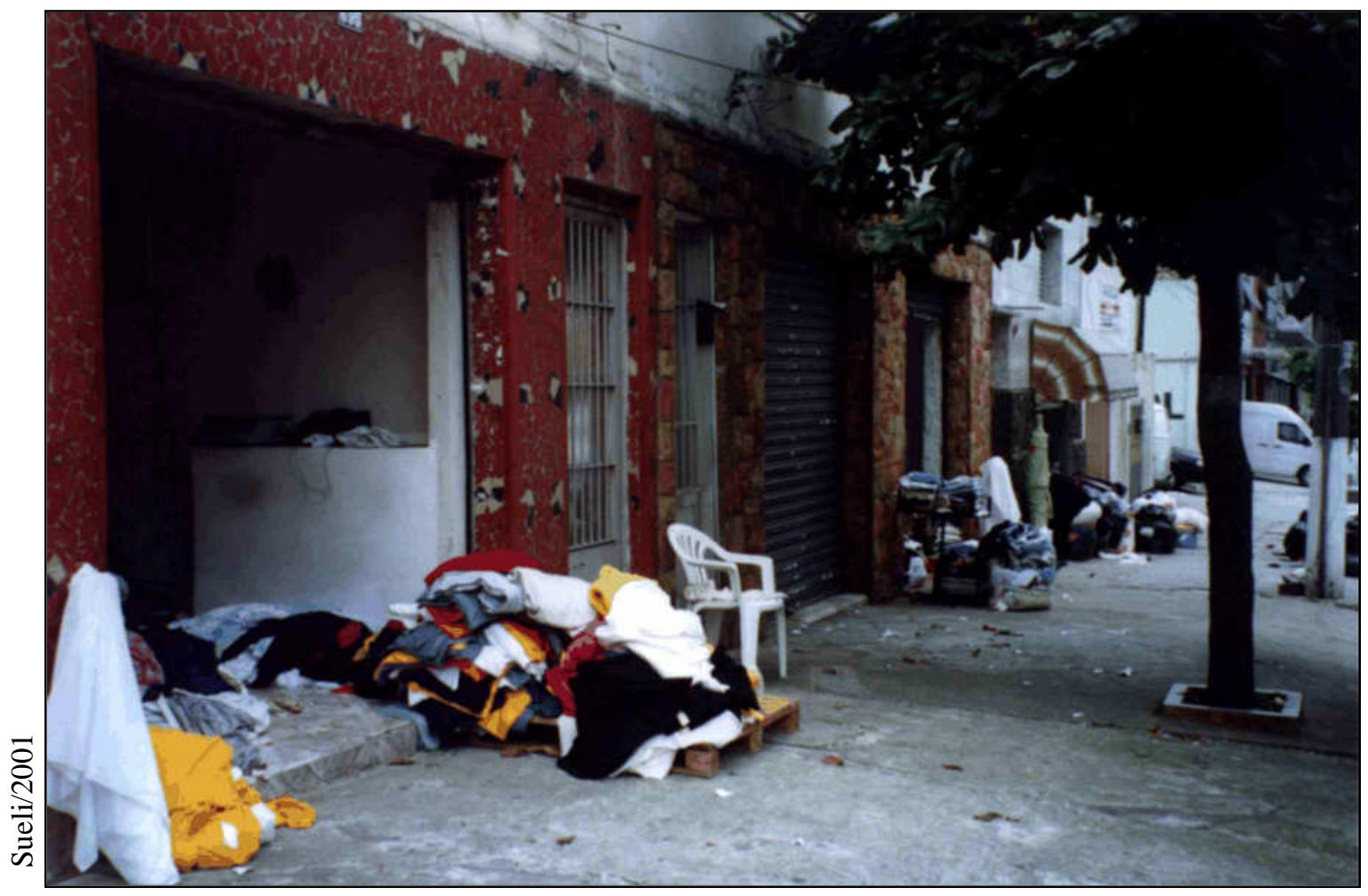

Foto 30: Parte da rua Almirante Barroso com lojas de retalhos e resíduos. 

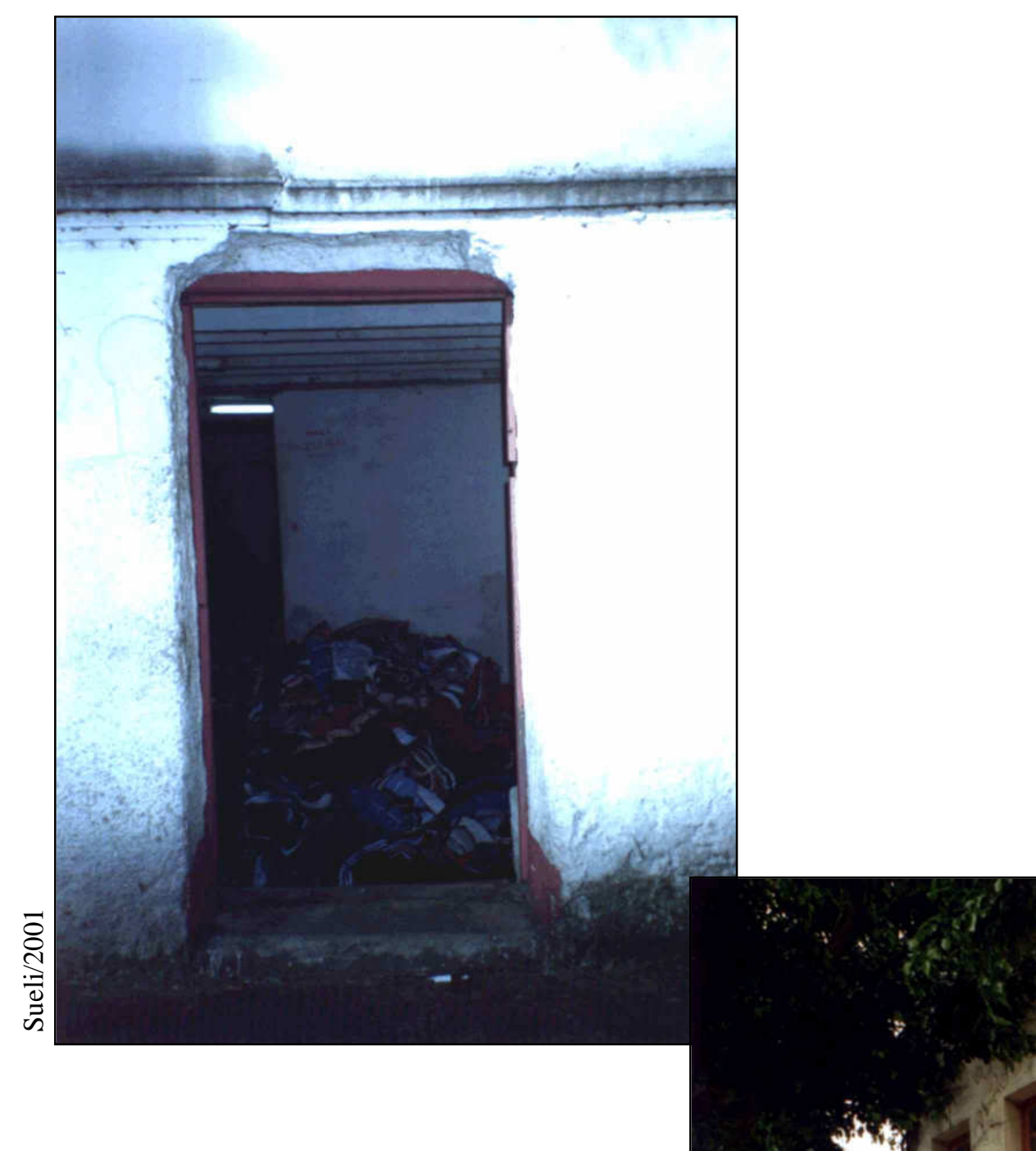

Foto 31 e 32: Os comerciantes de retalhos e resíduos, menos capitalizados, procuram os imóveis mais deteriorados. Esses imóveis tem dupla função, loja e moradia. 


\subsection{Organização, estrutura e funcionamento do comércio de retalhos}

Para entendermos a dinâmica da atividade comercial dos retalhos e resíduos é necessário estudar a sua organização interna. Esse comércio está inserido em uma trama própria da rede dos migrantes. Optamos por desmontar a circulação dessa mercadoria, em algumas etapas desse processo para facilitar a sua compreensão. Assim, a investigação dessa atividade parte da origem da mercadoria, matéria-prima elementar o retalho e o rejeito - chegando até o seu consumo final, em Santa Cruz do Capibaribe, na metrópole, ou em qualquer outra parte onde ele é comercializado.

\subsubsection{As fontes da matéria-prima}

Os retalheiros têm uma classificação e denominação diferentes para as suas mercadorias, e dessa forma adotamos nessa pesquisa essa diferenciação. Vejamos essa designação. Os retalhos ${ }^{27}$ são as peças maiores, podem ser encontrados desde alguns metros de pano até rolos de bobinas inteiros. Eles se originam dos restos de tecidos que não são aproveitados nas confecções, por apresentarem defeito ou as cores estarem fora da moda. Às vezes, eles vêm direto das indústrias têxteis. São mercadorias "encalhadas", "fim de estoque" ou que saíram fora do padrão de qualidade. Na indústria têxtil, modernizada, há um equipamento que controla o número de defeitos por metro quadrado. A partir daí, o tecido será classificado na própria indústria - desde o tecido de primeira linha, sem nenhum defeito até os retalhos. Assim, será calculado o valor dessa mercadoria. Os retalhos são cortes de tecido que no mínimo medem um metro. Já os resíduos são pequenas tiras de tecido que variam de tamanho, inferior a $30 \mathrm{~cm}$ de comprimento e largura. Os resíduos são os restos, as aparas, que sobram após o aproveitamento do tecido na indústria da confecção. Essas sobras podem se apresentar em forma de tiras, recortes, enfim, pedaços bem pequenos sem utilidade para a confecção. Então, a indústria da confecção junta esses resíduos e retalhos até ter um

\footnotetext{
${ }^{27}$ O dicionário Aurélio dá as seguinte definição para Retalho, entre outras - Sobra de tecido de costura ou de peça nas lojas. O Resíduo significa aquilo que resta de qualquer substância; resto, entre outras definições.
} 
volume razoável para a comercialização, podendo até levar um ano para obter de 500 a 600 quilos. Tudo depende da produção e das vendas.

As confecções que fornecem o seu rejeito estão localizadas, principalmente, no Brás, Bom Retiro e Belenzinho. A procura dessa mercadoria, ocorre, não apenas nos bairros centrais, envolverá, também outras confecções da metrópole. As indústrias têxteis que fornecem o retalho estão, principalmente, em Americana, Guarulhos, Campinas, Santos, envolvendo também as indústrias têxteis de Minas Gerais.

Tanto os resíduos, como os retalhos são negociados a partir do seu peso, o preço é determinado pelo tipo de tecido. No período da pesquisa, o resíduo estava cotado, em torno de $\mathrm{R} \$ 0,20$ o quilo (06.2001). Por envolver pequenas somas é pago à vista, geralmente, em papel-moeda.

Por essa razão, o retalheiro, normalmente, tem as chamadas 'firmas certas', isto é, um acordo entre a confecção e determinado comerciante de retalhos. Esses comerciantes têm que trabalhar com várias indústrias para a manutenção de seu negócio. $\mathrm{O}$ mesmo retalheiro tem um intervalo de 5 a 6 meses, no mínimo, para retornar na mesma confecção e se abastecer. Existe um acordo informal entre o comerciante e a indústria de confecção, levando a uma espécie de monopólio. Há uma diversidade das formas de relação, entre a confecção e o comércio de retalhos, pois há uma diversidade de formas de retalheiros. Veja o depoimento:

"Das lojas. Botava os empregados pra comprar. Eu tinha das lojas controlado nas lojas, prá gente pegá. Vai na loja, contrata o retalho. Toda vez que ele dá... junto o retalho. A gente vai lá e compra o retalho.” (Sr. Dudu)

Esse "controle", na verdade é o acordo prévio entre a confecção e o comerciante de retalhos. Assim, como essa reserva da mercadoria garante o funcionamento da atividade comercial. 


\subsubsection{Das indústrias de confecção e têxteis para os depósitos e lojas}

Para entendermos melhor o funcionamento e a organização da atividade comercial resgatamos, em MARX a teoria da circulação da mercadoria:

"O circuito percorrido pelas metamorfoses de cada mercadoria entrelaça-se, portanto, inextricavelmente com os circuitos das outras mercadorias. $O$ conjunto de todos os circuitos constitui a circulação de mercadorias”. (MARX, 1996: 125)

Para MARX o comércio é uma forma desenvolvida de circulação, e seu ponto de partida é o capital. Ele cita vários exemplos para demonstrar essa circulação com tipos de produtos diversos como o linho que é trocado por trigo. Assim, o comerciante vive da acumulação do capital e nessa circulação, usando a estratégia da especulação, tem como objetivo o giro do capital, em um movimento continuamente renovado para poder expandir:

"O vendedor recebe-a do comprador e a passa para outro vendedor todo o processo se inicia com a obtenção de dinheiro em troca de mercadoria, e acaba com a entrega de dinheiro contra mercadoria." (MARX, 1996: 168)

A troca entre as mercadorias, que estudamos, inicia-se a partir de um rejeito quando começa o trabalho dos catadores de retalhos, que não possuíam capital inicial, mas tinham a força do seu trabalho, agregando valor a essa mercadoria. $O$ valor agregado, também, aparece no trabalho de separação dos retalhos e resíduos, deixandoos prontos para serem comercializados. A circulação da mercadoria é analisada por MARX, como vemos na referência abaixo:

"A circulação é a soma de todas as relações mútuas dos possuidores de mercadorias. Fora dela, o possuidor de mercadorias só mantém relações com sua própria mercadoria. No que toca ao valor desta, a relação limita-se a conter ela uma quantidade do trabalho dele, medida de acordo com determinadas leis sociais. Essa quantidade de trabalho se traduz na magnitude do valor da mercadoria, (...). O possuidor da mercadoria pode com seu trabalho gerar valores, mas não valores que se dilatam. Pode aumentar o valor de uma mercadoria, acrescentando com novo trabalho novo valor ao valor existente..." (MARX, 1996: 185). 
Esses referenciais foram importantes para o prosseguimento das nossas investigações. Os resíduos, que eram considerados "lixo" nas confecções e foram "catados" nas calçadas, pelo "catadores" com carrinhos de madeira ou não, se tornam novas mercadorias e entram novamente em circulação.

O migrante acabou criando várias formas de inserção nessa atividade comercial de retalhos e resíduos, originando diferentes funções, que se interrelacionam: o catador, o correntista (intermediário), retalheiro com depósito e retalheiro lojista. Faremos uma breve caracterização dessas funções, durante a circulação do rejeito das indústrias para a sua comercialização e antes de caracterizar propriamente, o comércio. A estruturação desses ofícios interrelacionadas viabiliza a circulação da mercadoria.

Existe uma diversidade de situações que envolvem esse espaço comercial. Relatar essa circulação, se fossemos restringir a uma única forma, estaríamos fazendo um reducionismo. Desse modo, destacaremos algumas formas de relação entre a indústria e o comércio, para que possamos desembaraçar esse liame de situações, criadas pelas diversas formas de retalheiros que surgem, ao longo do desenvolvimento desse comércio. Partiremos, sempre, dos indivíduos que possuem menos capital, para os mais capitalizados. No sentido de entender essas diferenças, identificamos as seguintes funções, que podem se mesclar, não é uma segmentação rígida:
A) O Catador de resíduos
B) Os funcionários
C) O "correntista" - corretor
D) O retalheiro com depósito
E) O retalheiro com loja

Vejamos, então, cada uma dessas funções:

A) O Catador de resíduos

O "catador" é o indivíduo que apresenta as condições mais precarizadas. A indústria de confecções acumulam uma determinada quantia mensal de resíduos e doaos para o "catador" de retalho. Este, também, apresenta uma diversidade: existe o catador que trabalha com o carrinho do depósito, há o catador que possui seu próprio carrinho e, por fim, há aquele catador que não possuindo carrinho, recorre ao trabalho 
das crianças, cuja tarefa é guardar aqueles amontoados nas calçadas até o final da tarde, por volta das 17:00 horas. Nesse período, realiza-se com os interessados, a negociação.

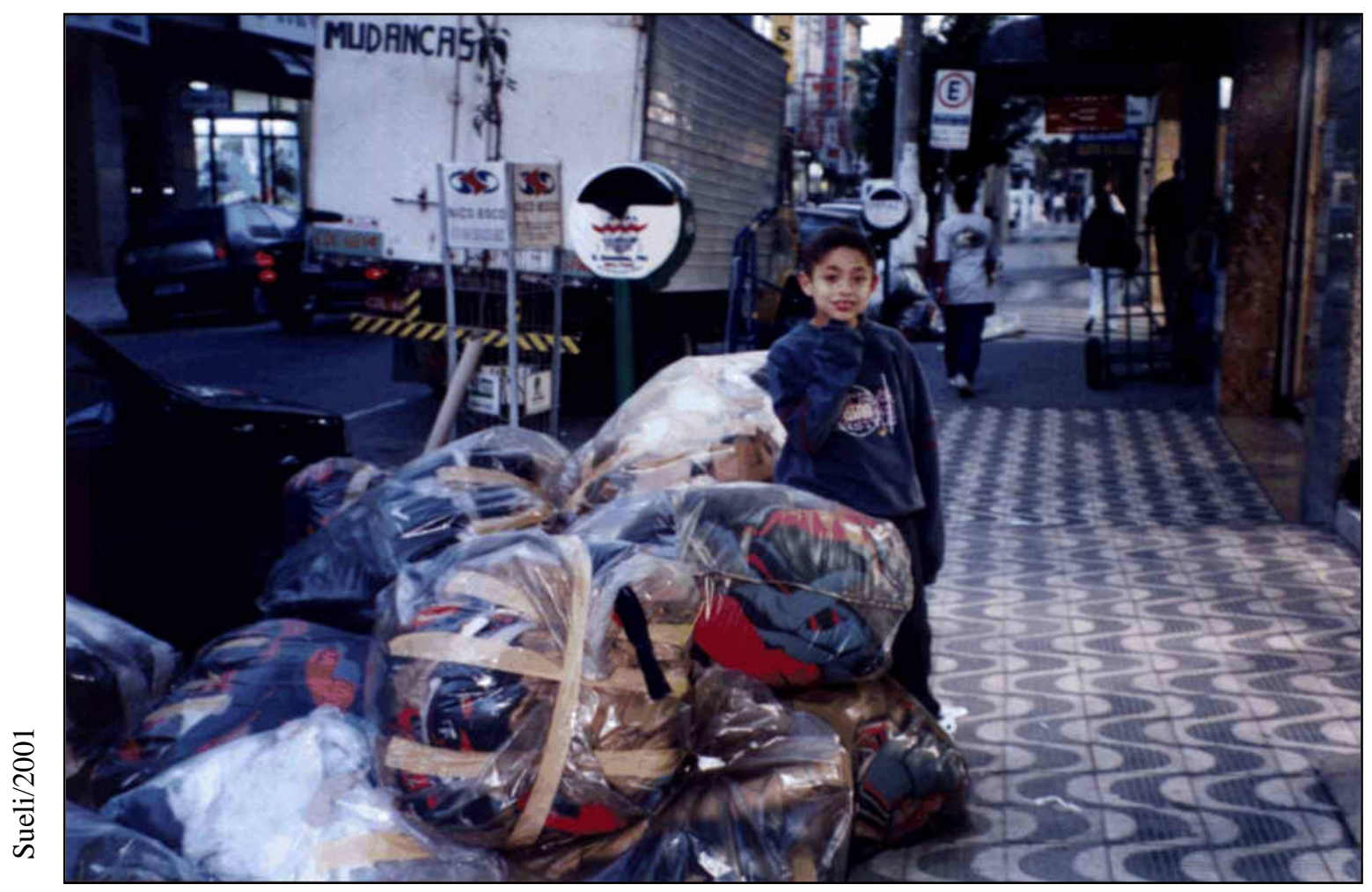

Foto 33: Os resíduos (rejeitos das confecções) são deixados nas calçadas, onde crianças ficam tomando conta até as peruas e/ou caminhões, no final da tarde, passarem para efetuar a compra. Cada "catador" tem seus pontos de coleta fixos nas confecções. 


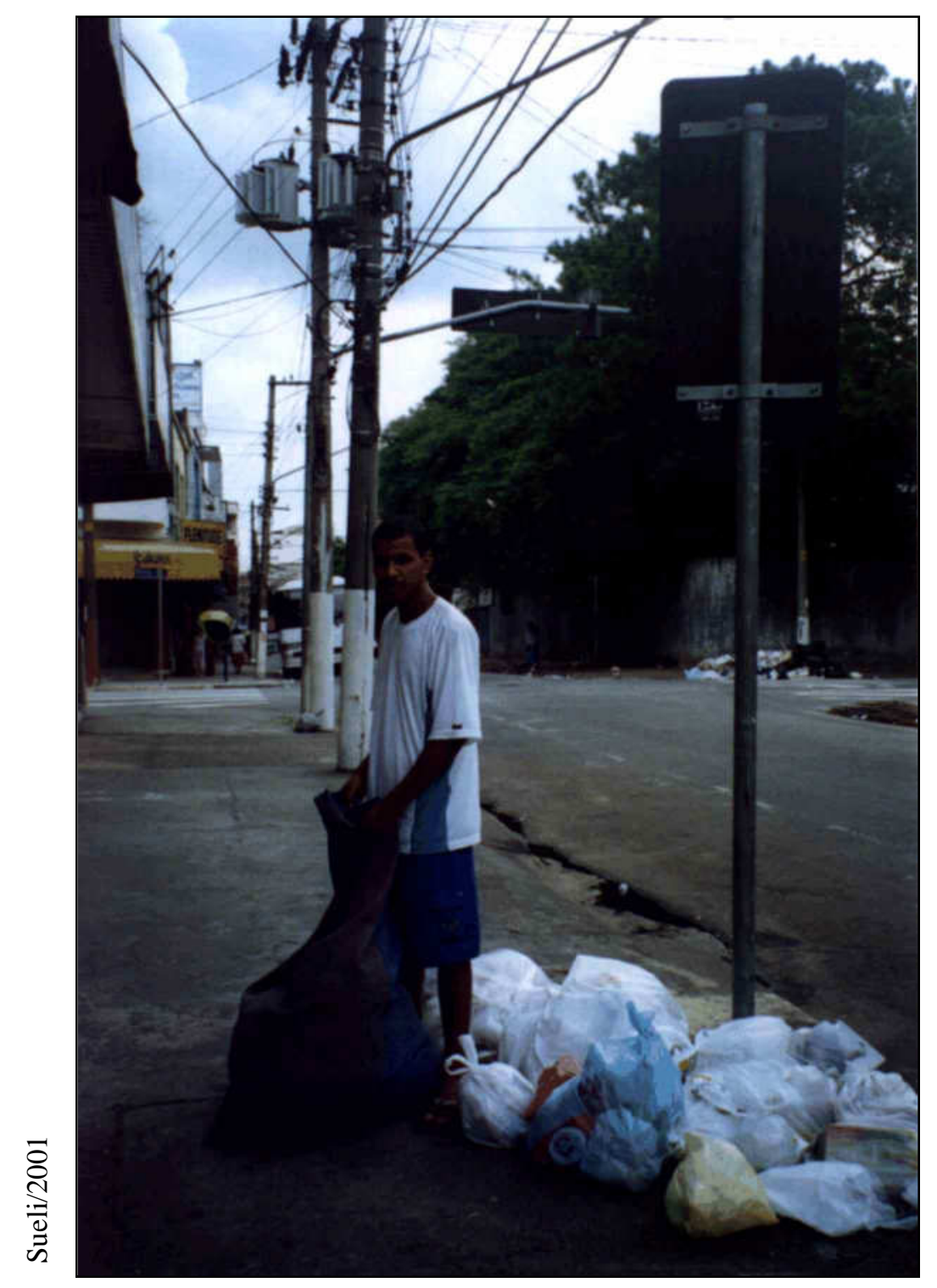

Foto 34: Esse catador carrega de 50 a 60 quilos de tecido nas costas, quase todos os dias. 
Nesse horário, passa o retalheiro com a perua e a balança para pesar os rejeitos. Dá-se a negociação. Assim, o rejeito se torna mercadoria no sistema de circulação e adquire um preço. O preço daquele lote, varia de acordo com o peso e o tipo de tecido.

Há o “catador' sem carrinho, tratado anteriormente, e há aquele com carrinho; esse carrinho pode ser seu, ou não, porém muitas vezes ele trabalha para um depósito, que detém o carrinho. Esse "catador" tem que dividir a sua coleta do dia com o depósito, que cede o carrinho para ele trabalhar. Esses catadores podem se especializar em catar retalhos, ou diversificar, também, catando papelão e outros materiais recicláveis, o que é muito comum.

Uma segunda forma de circular essas sobras das confecções, é quando aquele retalheiro, que passa com a sua perua, negocia, diretamente com as confecções, sem a intermediação dos catadores, que ficam sempre com o rejeito de menor valor. Nessa situação, a confecção não mais doa, mas vende o seu resíduo, e esse pequeno capital será administrado de diversas maneiras pelos proprietários das confecções. Há casos, em que esse valor se torna um adicional ao salário dos funcionários da confecção; há outras situações em que esse pequeno capital é incorporado pelos donos da confecções. A venda desses resíduos, muitas vezes, é justificada pelos proprietários, por ser uma forma dessas pessoas "darem valor" a esse produto; na verdade, é a ampliação do capital, por pequena que seja.

\section{B) Funcionários}

Encontramos em muitos estabelecimentos, tanto depósitos como lojas, funcionários que têm a função de atender aos clientes, separar os tipos de retalhos, carregar as compra, às vezes, para as sacoleiras e, principalmente tomar conta da loja, enquanto o seu proprietário corre atrás de mercadorias. Geralmente eles têm uma remuneração fixa e mais uma comissão pelas vendas. Eles podem ser conterrâneos ou não. 


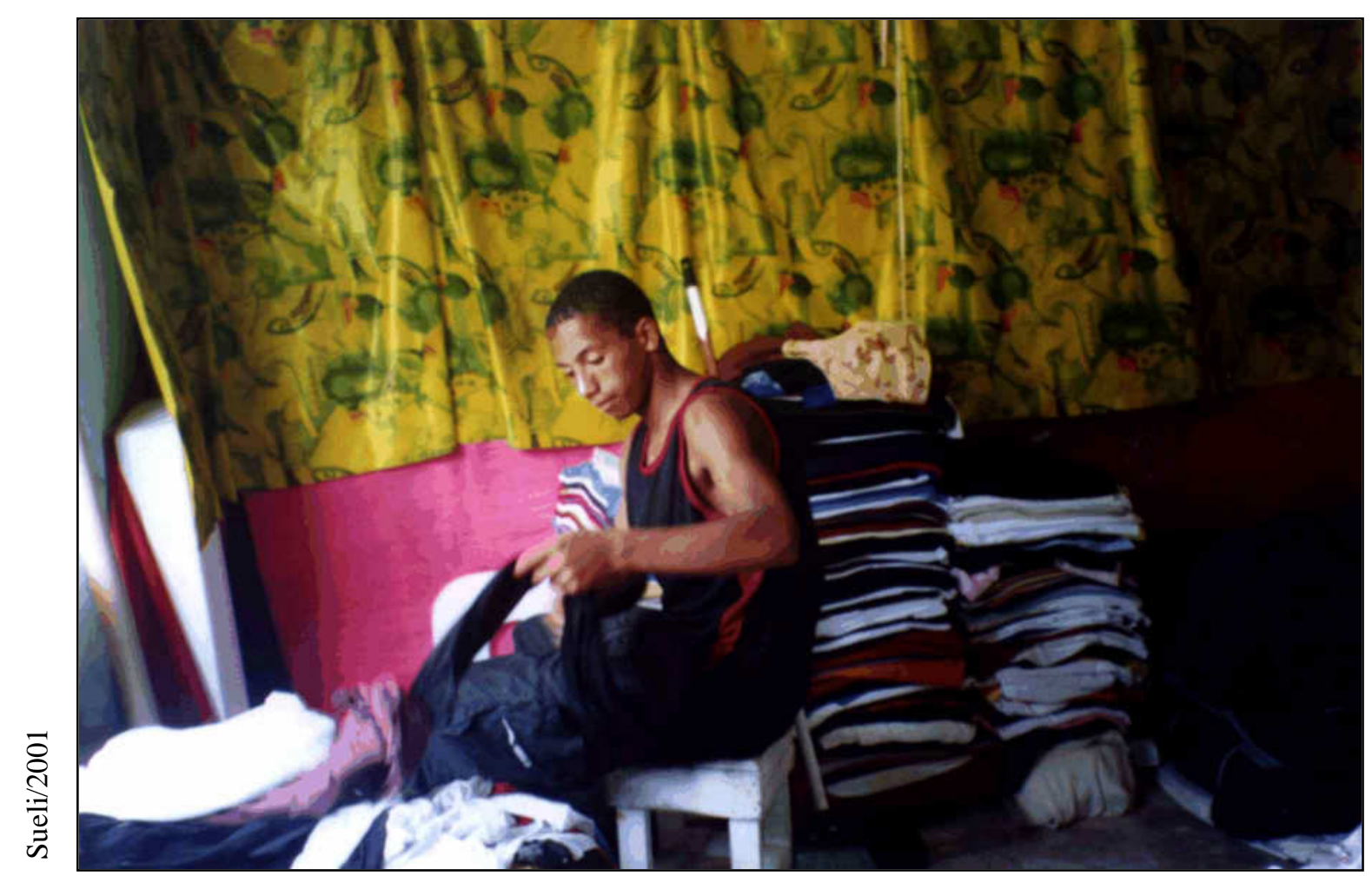

Foto 35: Funcionário separa os retalhos.

C) O "correntista" - corretor

A passagem confecção-depósito/loja pode se dar por meio do correntista, uma outra forma de inserção nessa atividade comercial. O correntista é uma espécie de especulador, que vai intermediar a negociação entre as indústrias têxteis ou de confecções e os depósitos e lojas. A maior parte das vezes, existe uma espécie de monopólio, entre os correntistas e as lojas e depósitos e também, entre o correntista e as indústrias. As negociações variam dependendo das relações e do monopólio do correntistas com a indústria e o comércio. Depois de fechado o acordo entre as partes envolvidas, com intermediação do correntista, a perua vai buscar o lote e é consagrado o negócio. Freqüentemente, um mesmo lote é revendido várias vezes e passa por vários retalheiros, que especulam em cima de um lote considerado barato. O mesmo ocorre com os retalheiros com uma maior capital, que não mais trabalham com resíduos, e sim, com retalhos. Há aqueles que compram direto das indústrias têxteis; eles já têm definidas as tecelagens. Nessa forma, também pode aparecer a categoria do correntista, que intermedia "o bom" negócio entre a tecelagem e a loja. Essa atividade não tem um 
lugar fixo, pois o correntista se desloca visitando as indústrias de tecidos, de confecção e as lojas.

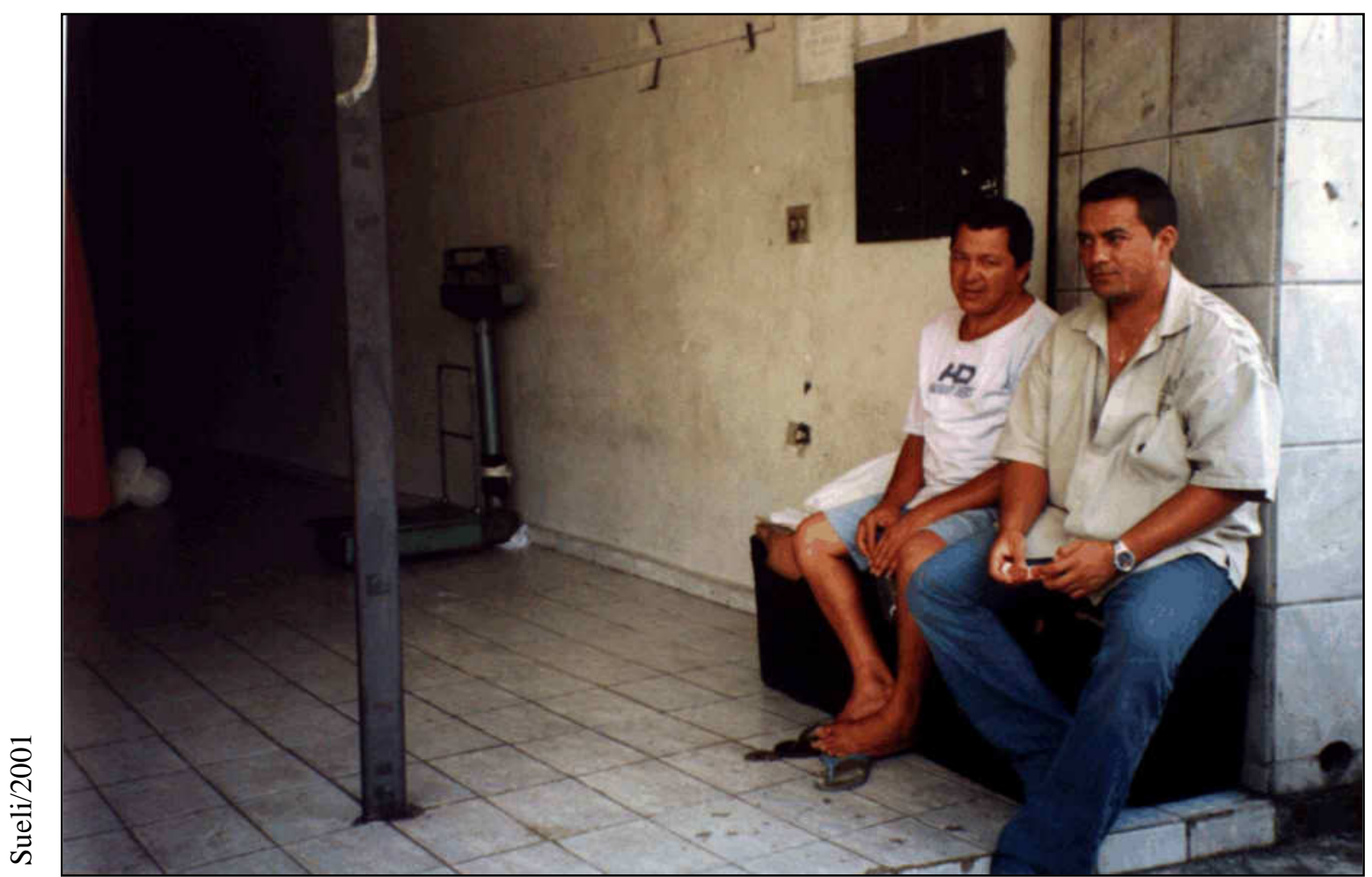

Foto 36:Os corretores têm como referência sempre uma loja ou um depósito. Encontramos sempre em grupos, de três até mais pessoas, nesses estabelecimentos.

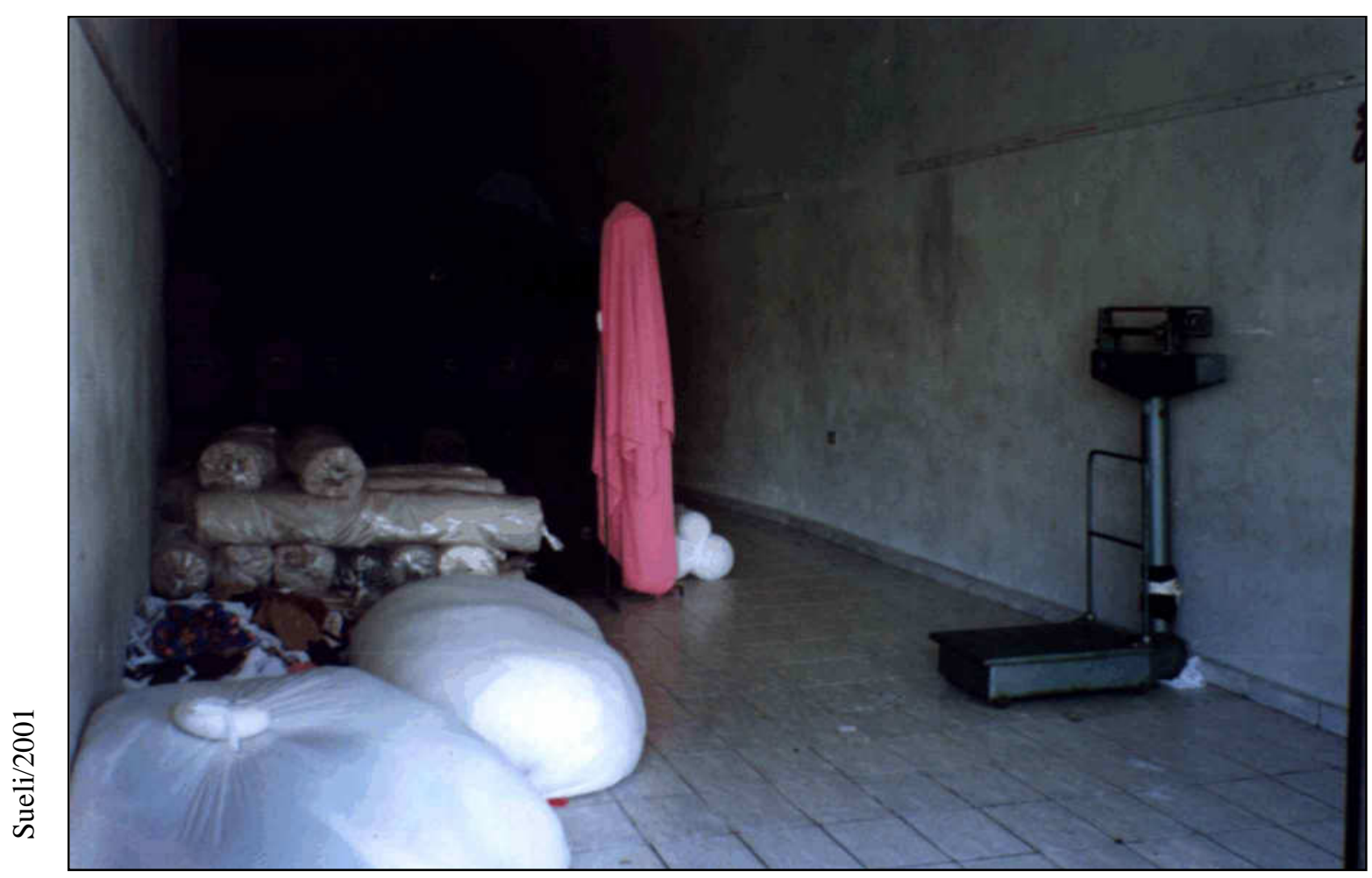

Foto 37: À noite, o migrante recém chegado estica um colchão neste espaço e dorme. De dia ele sai para a rua em busca de tecido. 
D) O retalheiro com depósito

$\mathrm{O}$ retalheiro que acumulou um certo capital, um pequeno pecúlio e adquiriu um local para depositar o resíduo para comercializá-lo, denominaremos de retalheiro com depósito. Muitas vezes, ele trabalhou como catador e arrastou muito carrinho; conseguindo, posteriormente, alugar um ponto, para formar o seu próprio depósito. Assim, o depósito representa uma pequena ascensão social dentro desse universo. Esses depósitos estão localizados nos locais que oferecem os aluguéis mais baratos pela distância dos centros comerciais ou por serem as construções mais deterioradas. Nessa instalação, ocorre a tarefa de separar os resíduos, por suas características e embalá-lo. Geralmente, o dono do depósito possui veículo próprio e dificilmente, trabalha sozinho. Os catadores vão revender para ele, bem como os correntistas. Pode ter ou não, funcionários, sempre trabalhando com os menores custos, se utiliza do trabalho familiar. O Seu Dudu relata um pouco desse cotidiano:

“Não de caminhão, mesmo. De carrinho, Já apanho muito, de carrinho. Apanha muito. Tinha os carreteiro de carrinho. Os que pegava, também, eu comprava a eles na loja, já, no depósito e tinha eu direto, também, que eu comprava. Eu tinha três Kombis, naquela época, com os empregados, (caiando) pegando material e trazendo para a minha loja. Aí, fornecia para os espanhóis.”

"Uma lá, vez uma casa ou outra, quando é quantidade grande, ele pega (fábrica de moer), mas a maior parte quem pega é as pessoas. Eu pelo menos eu comprava, apanhava os retalhos de Kombi e dos carreteiro de carrinho trazia para a minha loja, fazê o depósito. Aí no depósito pegava o retalho e enfardava, enfardava todinho, quase 100 quilos, mais, pra mandar para as fábricas, prá mandar para as fábricas para desfiar.” 


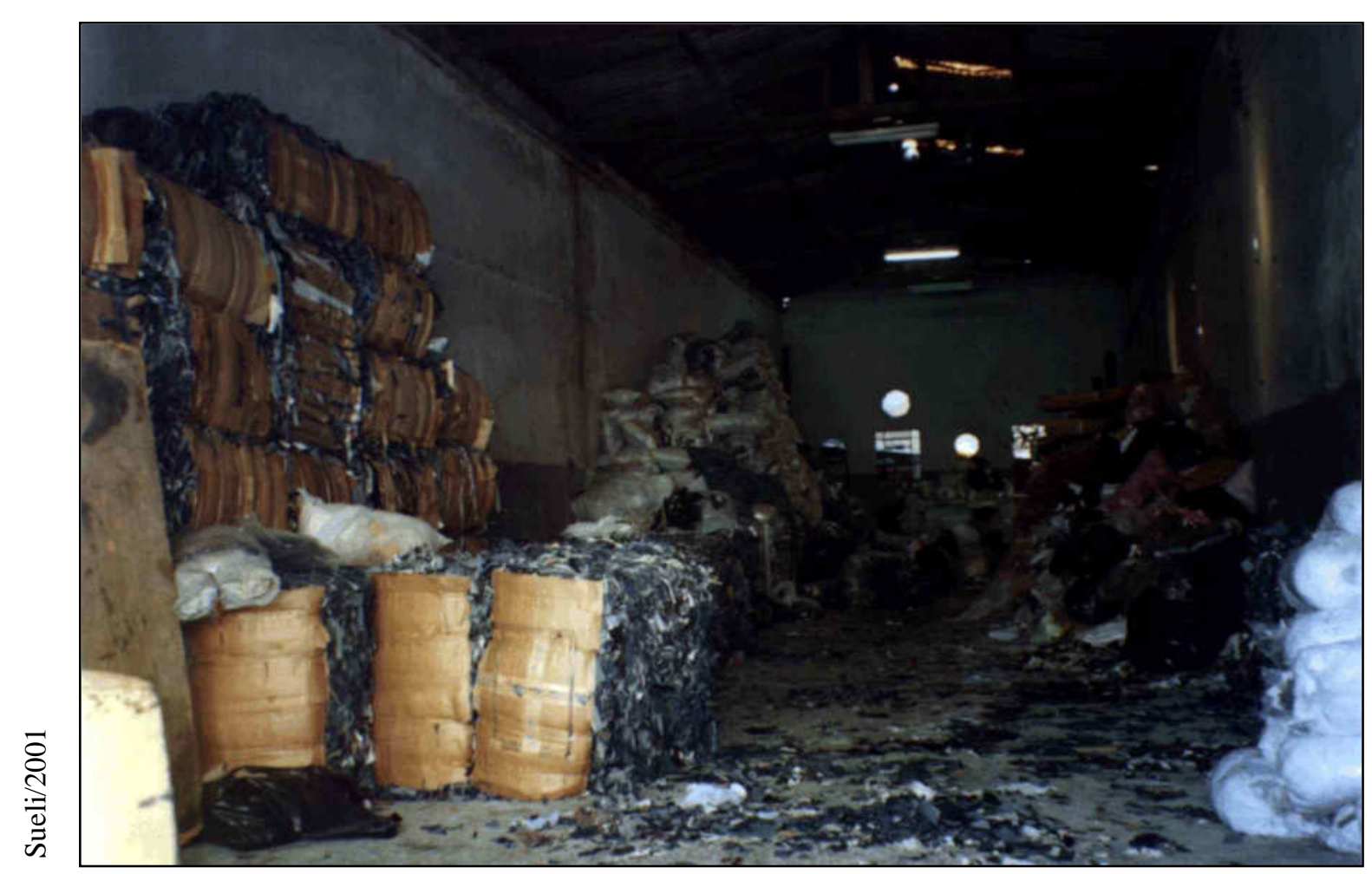

Foto 38: Depósito na rua Dr Carlos Botelho. Esse depósito fornece a matéria prima para o estofamento e outros componentes da indústria automobilística. Pertence a João Arantes de Ibirajuba.

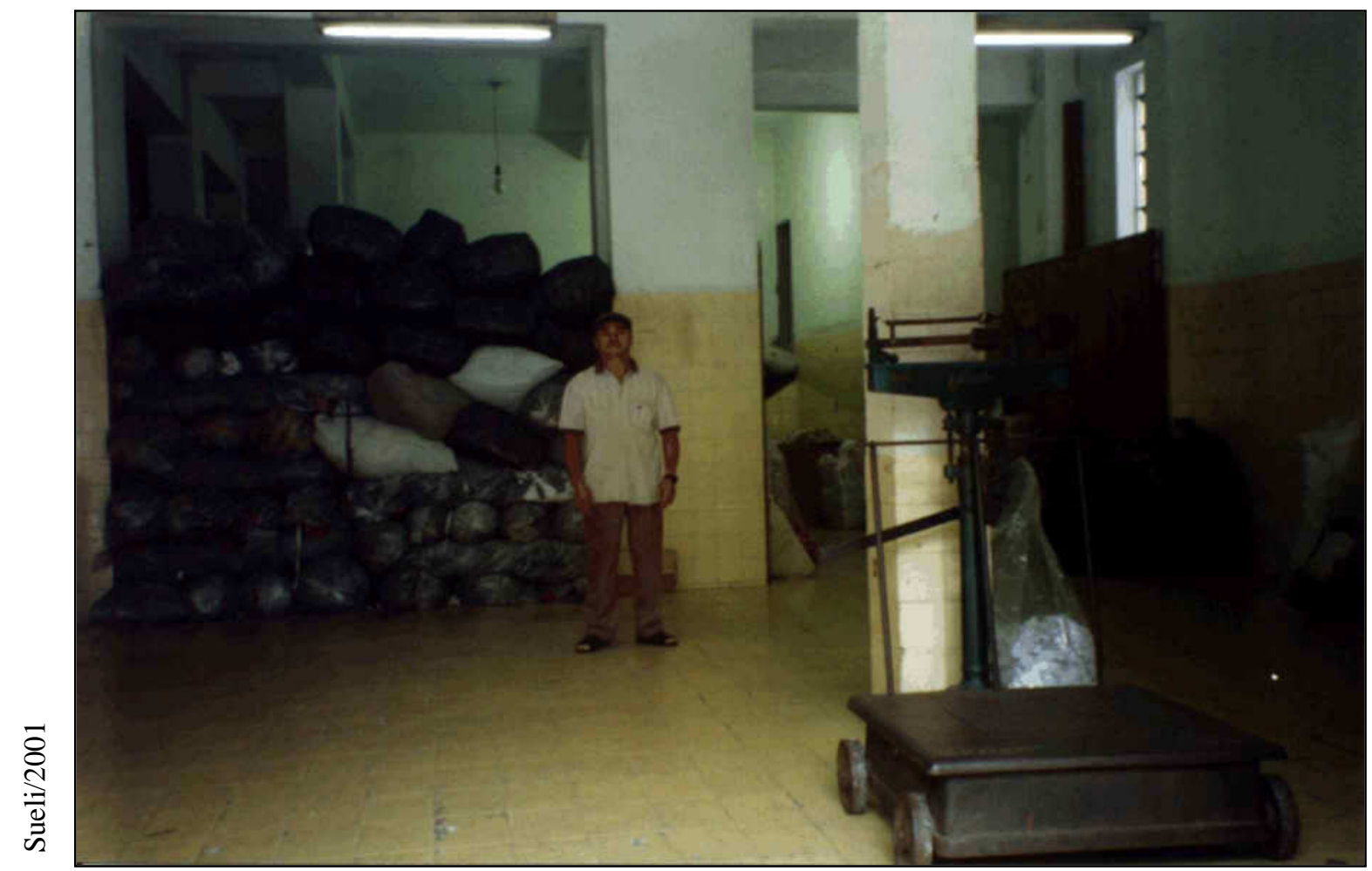

Foto 39: Senhor Osmar é proprietário de dois depósitos e mora nos fundos do depósito fotografado na rua Visconde de Parnaíba. 
E) O retalheiro com loja

O retalheiro com loja é o comerciante mais capitalizado. Aos poucos foi mudando o tipo de mercadoria, conforme ia se capitalizando. Deixando de trabalhar com resíduo e passando a trabalhar com retalhos. Há nesse grupo uma diversidade de gradação, entre a quantidade de retalho e resíduo, pois eles se encontram em um processo de acúmulo de capital, via essas mercadorias. Seu Dudu nos contou que trabalhou dezoito anos com resíduo, para depois passar a trabalhar com retalho. Normalmente, o comerciante com loja, já possui casa própria, veículos e os melhores pontos de venda, mais próximos das indústrias de confecção e as áreas que circulam os sacoleiros. Alguns já possuem mais que uma loja e investem em publicidade, como encontramos na Internet e nas páginas amarelas.

Essas situações podem se mesclar. O mais significativo é perceber a diversidade do comércio e ao mesmo tempo, a complexidade, tornando-se mais complexo esse emaranhado de redes de contato e negócios. Na busca do giro do pequeno capital, ocupando todos os interstícios, muitos migrantes vão se inserir de diversas formas nessa atividade.

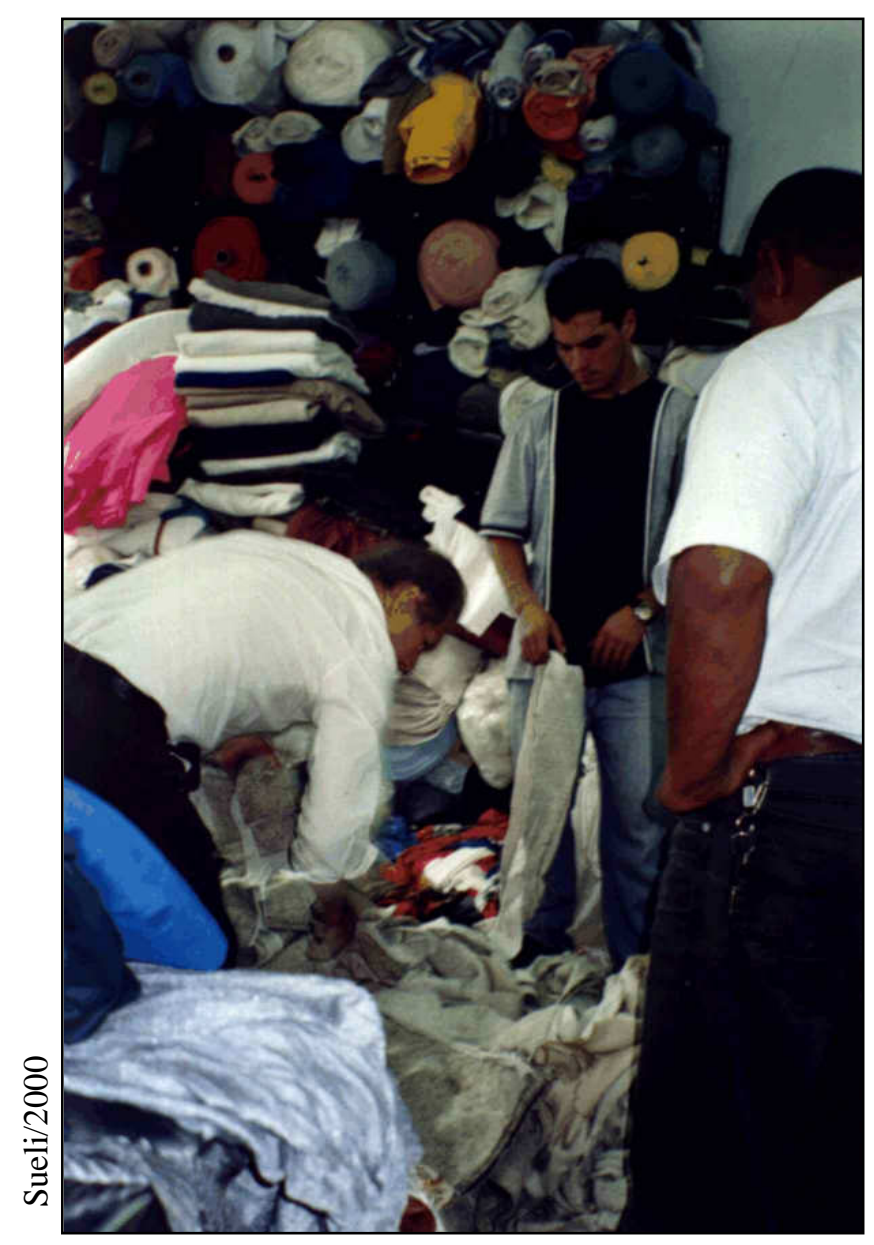

Foto 40: O trabalho do comerciante de retalhos é dividir o tecido em partes menores, para depois revender por quilo. 


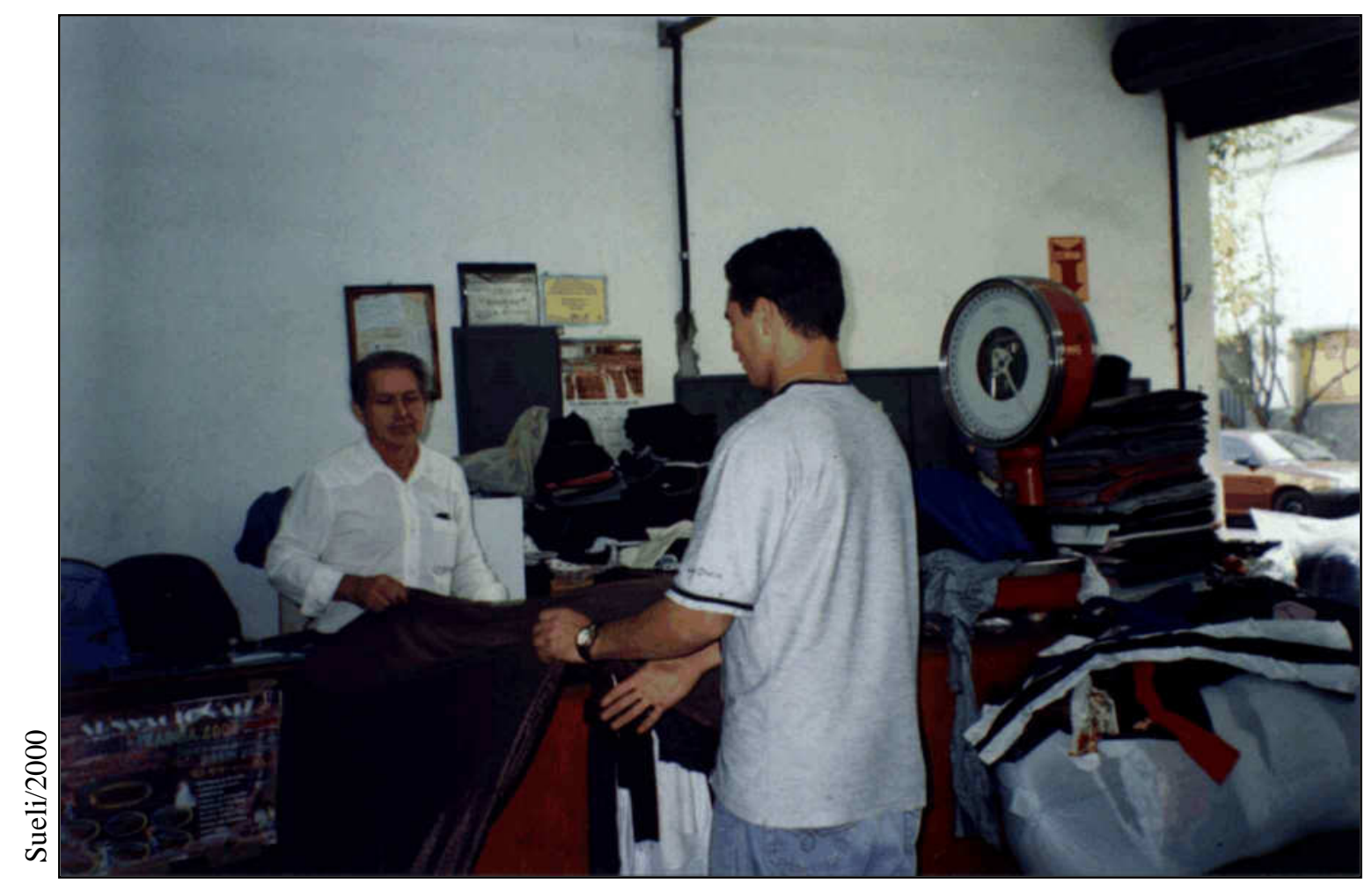

Foto 41: A escolha, a separação, compra e venda são funções que o comerciante de retalhos têm nessa atividade.

\subsubsection{Organização do comércio}

Esse comércio de retalhos e resíduos não exige necessariamente, um capital inicial. Grande parcela desses migrantes se inserem nessa atividade com o seu próprio trabalho, gerando um pequeno capital, que possibilita, posteriormente, possuir seu próprio depósito e depois com um capital maior, a sua loja. Há casos em que o migrante possui um pequeno capital, fruto, algumas vezes, de um FGTS, quando era trabalhador regulamentado e esse resolve ter o seu próprio negócio. Outros migrantes em seus depoimentos revelam que o capital vem de uma poupança ou da venda de um automóvel. Os mais antigos, os precursores e, atualmente, também, os correntistas, iniciaram-se na atividade, sem nenhum capital, apenas negociando, separando os retalhos e assim formando seu capital, até conseguir ter um local para a sua instalação, com firma registrada. Esse comércio nasce na informalidade e com um pequeno acúmulo, passa a ser formal. 
"Se tivesse que emprestar do banco nem tinha começado. Compra, vai comprando, compra hoje 10 quilos, amanhã 15, vende, depois compra e vai indo.” (Xique-xique).

"Catando retalho pros outros, foi escolhendo, primeiro alugou uma casinha, pequena mesmo, tamanho de um banheiro...”. (Tânia)

Todos contam o trabalho e o sacrifício que enfrentaram para conseguir o seu próprio depósito. Para trabalhar nessa atividade comercial exige-se um local para escolher os retalhos e os resíduos; muitos, recém integrados na atividade e descapitalizados, pedem emprestado o espaço físico da loja ou depósito do conterrâneo. Outros, utilizam a sua própria moradia como espaço de trabalho. Os retalheiros, mais capitalizados, alugam um salão. Nessa estrutura comercial, além do local, é necessário uma balança, um telefone e um veículo para buscar o retalho nas confecções. São empregados vários tipos de balança. O telefone é peça importante na negociação. $\mathrm{Na}$ sociedade contemporânea, até o pequeno comércio vai depender dos meios técnicosinformacionais para realizar o seu negócio. O telefone viabiliza muitos negócios e economiza tempo e dinheiro. Por meio dele são feitos os contatos com as confecções ou com as tecelagens; discute-se valor, quantidade, a existência de um lote de mercadorias, bem como informações para os clientes de Pernambuco e outras localidades.

"... o telefone é a arma do negócio. O Senhor veja uma firma liga pra mim..." (Sr. Zuca).

O atacadista de Santa Cruz do Capibaribe, reafirma a importância desse meio de comunicação na circulação, conforme está registrado no depoimento abaixo:

“... Eu vendo mais é pras sulanqueiras e a crédito. E nem tô muito interessado mais nisso não. Nem pra São Paulo eu tô indo mais. Eles é que telefonam pra eu fazer o meu pedido.” (CAMPELLO, 1983: 126)

Os retalhos são adquiridos e embalados em sacos de nylon, farinha, algodão, plástico etc. Essas embalagens não são consideradas de grande custo, pois pode ser reutilizada diversas vezes. A mercadoria será embalada dessa forma, tanto para o deslocamento das confecções e tecelagens para as lojas e depósitos, como, das lojas e depósitos para os outros locais de destino. O transporte das confecções e das tecelagens para as lojas e depósitos é de responsabilidade do retalheiro. Os mais capitalizados têm 
seus próprios veículos, os menos capitalizados alugam-no. Em geral são utilizados peruas e caminhões.

As tarefas executadas nesse comércio são:

- A compra de retalhos nas confecções. Ela pode ser executada, o que é mais comum, pelo correntista que 'especula' o retalho. Ele diariamente vai à procura da mercadoria. De modo geral, ele comercializa para uma determinada loja, mas também, pode, apenas, usar essa loja como local para depositar seus retalhos e vender para qualquer outro lojista de retalhos; quando este é o dono do local, ele pagará, com a porcentagem da negociação. A busca pela mercadoria e sua compra pode ser feita por telefone, ou visitando-se lojas. Segundo depoimento, para essa transação são realizados cerca de quase 80 telefonemas, diariamente, sempre no início do mês, para assegurar a mercadoria durante o mês, nas mãos do mesmo correntista. Esse mesmo que continuará mantendo o contato para confirmar o negócio. Muitas vezes, é necessário que esse correntista faça algumas viagens para a área fonte da mercadoria tais como Americana, Santos, Campinas, ou outra cidade que possua tecelagens ou confecções.

- Depois que a loja compra o lote de retalhos e resíduos é preciso fazer a separação destes, pois na maioria das vezes vem misturado. O lote é dividido seguindo os critérios de tamanho, cor, tecido.

Não há como quantificar o tempo de realização desse trabalho, pois essas tarefas variam muito. Mas as lojas permanecem abertas no horário comercial, normalmente, aos sábados também até o meio dia. Essa situação é muito comum, principalmente, se o local de trabalho, também, for moradia. Os depoimentos dos comerciantes registram esse sobretrabalho. Eles fecham a loja e continuam a trabalhar lá dentro, como mostra o depoimento abaixo:

"Não existe. Tem cara que dorme, tô falando em firmas, aí os caras dormem lá dentro é de 24 horas por dia. É 24 horas de dedicação total." (Xique-Xique)

Essa unidade produtiva aparece de forma diferenciada, tanto como uma atividade do comércio formal como informal, ou melhor, no primeiro momento ela é informal, circuito inferior, em que o retalheiro não tem acumulação suficiente; depois, com um maior grau de acumulação do retalheiro, ela passa a ser formal, circuito superior. Foge a essa situação os retalheiros que começam com um capital inicial, tendo condições de abrir uma firma e arcar com seus custos. 
A maior parte dos comerciantes afirma possuir firma registrada, pagar os impostos, e reafirma não gostar de ter "problemas e complicações". Esses funcionam, com uma única firma aberta, legalmente. No entanto, por trás dessa firma trabalham muitas unidades autônomas desregulamentadas, como os correntistas, que se servem do proprietário da loja que tem firma aberta e lhe pagam uma porcentagem dos seus lucros; ou não pagam, na maior parte das vezes, nada, valendo-se da amizade.

Se formos considerar a atividade comercial fora do controle do Estado, veremos que existe uma rede legal e uma outra ilegal, coexistindo nos mesmos espaços, de forma hierárquica, como uma maneira de os chamados "excluídos" buscarem a sua inclusão na sociedade. Para melhor estudarmos essa questão, nos apoiaremos em SANTOS (1979b) ao discutir o circuito inferior e superior da economia que compõem o mesmo processo.

\subsection{O comerciante de retalho e resíduo}

A primeira característica que destacamos nesse grupo, que comercializa os retalhos e resíduos, é o fato de ter vivido a experiência da migração. Quando fomos rastreando, a partir das conversas e entrevistas, identificamos que boa parcela desses comerciantes, que denominamos retalheiros são migrantes. Os demais são os filhos ou netos de migrantes que herdaram o legado do pai, ou então, esposa que casou com migrante ou um amigo que foi introduzido na atividade por meio de um migrante.

Assim, o que une, de uma forma mais próxima ou mais distante, esse grupo de retalheiros é a migração. Em um primeiro mapeamento da área de origem desse grupo, identificamos que o maior grupo é oriundo da cidade de Ibirajuba, e outros grupos oriundos de outras cidades de Pernambuco e os arredores da cidade de Santa Cruz do Capibaribe, esses grupos são pernambucanos, Um terceiro grupo, bem menor, é oriundo da cidade de Iguatu, no Ceará. Houve alguns casos que apareceram nas entrevistas mineiro, paraense, paulista, que foram introduzidos na atividade por possuir algum grau de parentesco com os migrantes das áreas acima. Nesta pesquisa vou enfatizar e procuro acompanhar a trajetória do grupo de nordestinos. Identificamos também a presença de alguns coreanos que estão se inserindo, também nessa atividade.

A presença do migrante nordestino no Brás, como já foi tratado anteriormente, nos conduz a entender o controle que esses migrantes nordestinos têm sobre a atividade 
comercial de retalhos. Em algumas circunstâncias, principalmente, por parte dos "catadores de retalho", o comércio de retalhos é uma estratégia de sobrevivência. Quando esses se encontram mais capitalizados, o comércio se torna uma estratégia de inserção nessa sociedade capitalista. Existindo, uma hierarquização e até um mecanismo de ascensão social, como discutiremos mais adiante. De qualquer forma, o comércio de retalhos que o migrante mantém é uma das formas ou condições para a sua reprodução em São Paulo.

As entrevistas abarcaram migrantes de várias gerações e que vieram para São Paulo, desde os anos 50, até os últimos 5 anos. Os migrantes mais antigos vieram jovens. Há um grande grupo de entrevistados, que veio na infância, acompanhando os pais. Grande parcela, tem sua origem na área rural, os que faziam parte da PEA (População Economicamente Ativa), trabalhavam na pecuária, os que pertenciam ao não PEA, isto é, as crianças, foram desconsideras. O mais significativo, nesse resultado, é o fato de todos eles não conhecerem essa atividade, em sua área de origem. Salvo, alguns migrantes de Santa Cruz do Capibaribe.

Nos depoimentos aparecem a falta de perspectiva de emprego para os jovens e esses são atraídos pelo "sucesso" de seus parentes em São Paulo, levando-os a migrar, estabelece-se, então, a rede social, que será aprofundada no capítulo três.

A outra parte do grupo de migrantes, que não veio diretamente para o comércio, que compõe, a faixa etária dos migrantes com mais de 40 anos, e portanto passou por um outro contexto econômico, um pouco diferente dos mais jovens, declarou que exerceu as mais diversas atividades quando eles chegaram em São Paulo, mas sempre no setor econômico mais precarizado, que exigia pouca qualificação, como: vendedor de pipocas, de sorvete, de papelão, balconista, motorista, empregada doméstica, caminhoneiro, metalúrgico, bancário etc. Desse grupo, a maior parcela é masculina e na faixa etária mais elevada. Em relação as atividades anteriores predominaram os indivíduos que sempre trabalharam por-conta-própria e muitas vezes, na economia informal. A outra parte desse grupo era trabalhadores regulamentados, como bancário, metalúrgico. Outros foram mobilizados para o comércio de retalhos devido às demissões, fruto da imposição do capital, nas últimas décadas. Os assalariados, diante do desemprego, são apresentados e inseridos nessa atividade, por meio de amigos e parentes, sempre um conterrâneo. O outro grupo de migrantes retalheiros é composto 
por mulheres e jovens, em que o comércio de retalhos tornou-se primeira experiência de trabalho.

Às vezes, o comércio representa uma complemento na renda familiar. O marido trabalha, no mercado formal e a esposa fica encarregada de manter a loja. No entanto, mesmo à distância o marido tem o papel de administrar a contabilidade do estabelecimento e gerenciar.

Os migrantes mais antigos possuem casa própria, automóvel e seus filhos curso superior. Estes migrantes continuam a trabalhar nas lojas, pois eles formaram mais que uma unidade comercial e deixam para os seus filhos administrarem. Entretanto, os migrantes, que entraram após os anos 70, moram de aluguel. Assim, os retalheiros mais recentes não conseguiram nenhum bem significativo com essa atividade, mas sim, apenas o sonho da ascensão, defere-se pelos depoimentos.

No decorrer da pesquisa, observamos uma mudança nos comerciantes estabelecidos. Há dez anos, havia predomínio intenso do migrante retalheiro com pouca escolaridade, atualmente, encontramos nessa atividade os filhos e irmãos de migrantes com uma formação profissional universitária. Esses puderam estudar, com o apoio do retalheiro e, hoje, assumem o comércio, até que encontrem um emprego que lhe dê a mesma condição de remuneração que o comércio, são esses: economista, matemático, advogado, artista plástico etc. Assim, constatamos que o comércio de retalhos envolve três gerações, com as suas singularidades. Não foi possível determinar, a partir das entrevistas, o período de maior fluxo migratório pesquisado.

De modo geral, os migrantes pensam em continuar no ramo e deixa-lo como herança para os seus filhos. Os mais antigos comerciantes sonham em voltar para o Nordeste, porém, os jovens, não. Os velhos retalheiros, presos pelos laços familiares construídos em São Paulo, apesar da saudade da sua terra de origem, voltam apenas para visitá-la. Há muitos outros elementos para construirmos esse perfil, todavia a dimensão do indivíduo migrante, é muito maior que a proposta de nossa pesquisa, então escolhemos dois aspectos a serem mais aprofundados nessa pesquisa. O primeiro aspecto é a grande procura desse nordestino pelo negócio próprio e o segundo, a sua inserção no comércio de retalhos, pela rede social, então preferimos dedicar a esses aspectos nos capítulos seguintes. Por ora, continuaremos a seguir o circuito da mercadoria retalho, para não fugir o propósito desse capítulo e discutirmos o comércio de retalhos e seus meandros. 


\section{$2.4 \mathrm{O}$ destino final da mercadoria}

Ao acompanharmos o trajeto da mercadoria, destacamos alguns percursos fundamentais - desde a fonte da matéria-prima até chegar ao seu consumo final. A realização dessa mercadoria retalho se faz quando ela é comercializada, isto é, ela é vendida para o seu fim. Devemos recordar, que várias vezes o mesmo lote de retalho e resíduo, passa muitas vezes por diferentes retalheiros, nesse mercado, que atuam, quase sempre, como se essas fossem ações da bolsa de valores. A importância do retalho, quanto ao seu uso, passa a ser menor, e o seu valor de troca, se torna mais significativo.

Os principais compradores podem ser divididos em quatro grupos básicos. $\mathrm{O}$ primeiro grupo é formado pelas costureiras da Grande São Paulo e do interior do estado. O segundo grupo, será formado pelas "sacoleiras", que têm o objetivo de revender essa mercadoria. O terceiro grupo é composto por empresas que utilizam essa mercadoria sua matéria-prima - em diversos produtos industrializados. E o quarto grupo compõemse dos donos de confecções e atacadistas de vários estados do Brasil, sendo que neste último, se destacam os atacadistas e a indústria da Sulanca que tem seu início e maior adensamento em Santa Cruz do Capibaribe e atualmente, essa área está expandida para as cidades de Caruaru, Toritama ${ }^{28}$ e Brejo da Madre de Deus ${ }^{29}$, municípios no estado de Pernambuco, formando um pólo da indústria de confecções de sulanca em Pernambuco. (Veja o mapa no 5 - O Pólo da Indústria de Sulanca - PE.)

Um grande número de costureiras procuram o retalho e resíduo, para baratear o custo da confecção de roupas, tapetes, colchas e outros. Essas costureiras trabalham porconta-própria ou costuram para o seu próprio uso.

\footnotetext{
${ }^{28}$ Cidade vizinha de Santa Cruz do Capibaribe que compram especificamente o tecido brim para jeans.

${ }^{29}$ Nesse município são produzidas as colchas de retalhos. As costureiras moram nos sítios e, geralmente, trabalham por facção. Essas colchas são vendidas na Feira de Santa Cruz do Capibaribe.
} 
MAPA 5

\section{Pólo da Indústria de Sulanca PERNAMBUCO - PE}

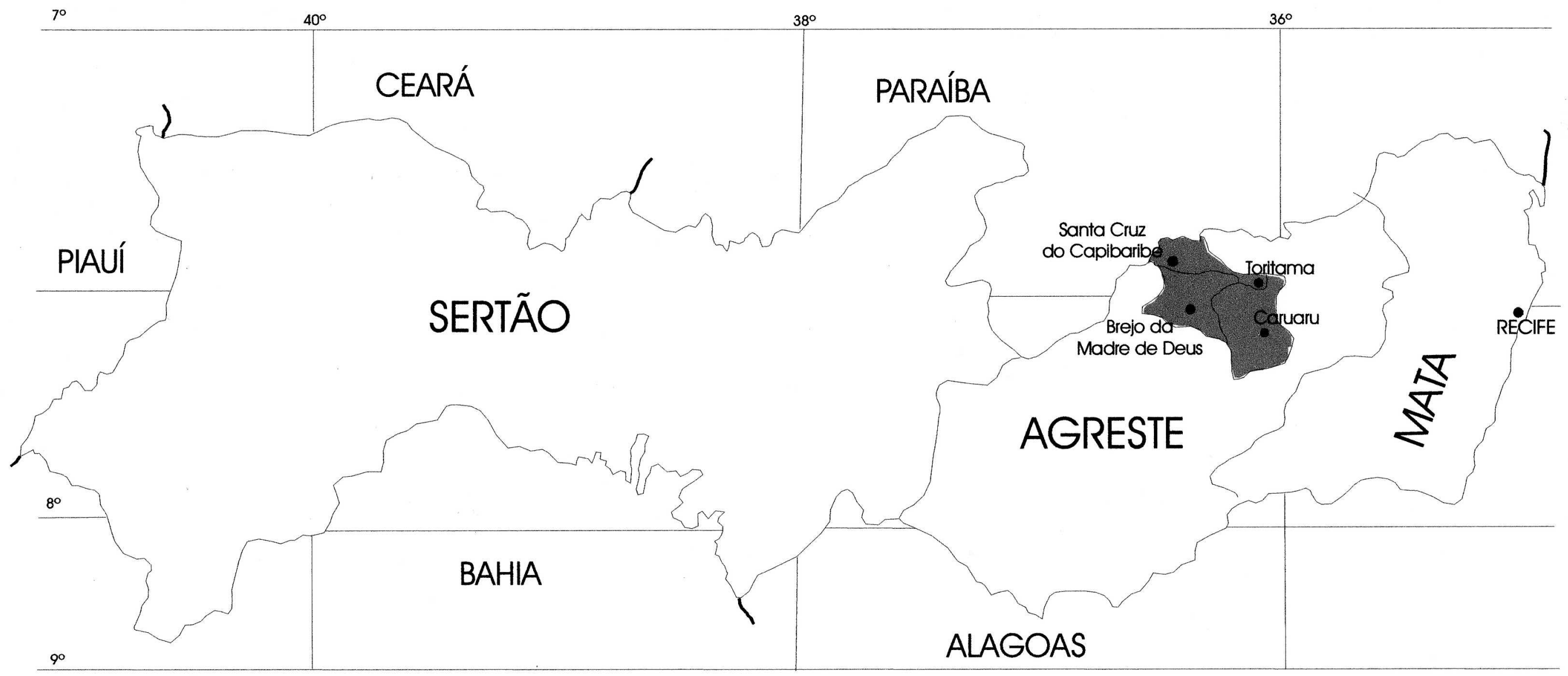

Fontes: Pernambuco - Microregiões geográficas. Escala 1:2.300.000

FIDEPE - Fundação de informações para o desenvolvimento de Pernambuco. Santa Cruz do Capibaribe.

Série monografias municipais. Governo da Secretaria de Planejamento. Recife. 1982

GEOATLAS. SIMIELLI, M. Elena. Ed. Ática, 2000.

Organização: Sinthia Cristina Batista e Sueli de Castro Gomes. São Paulo, 2002

Escala aproximada 


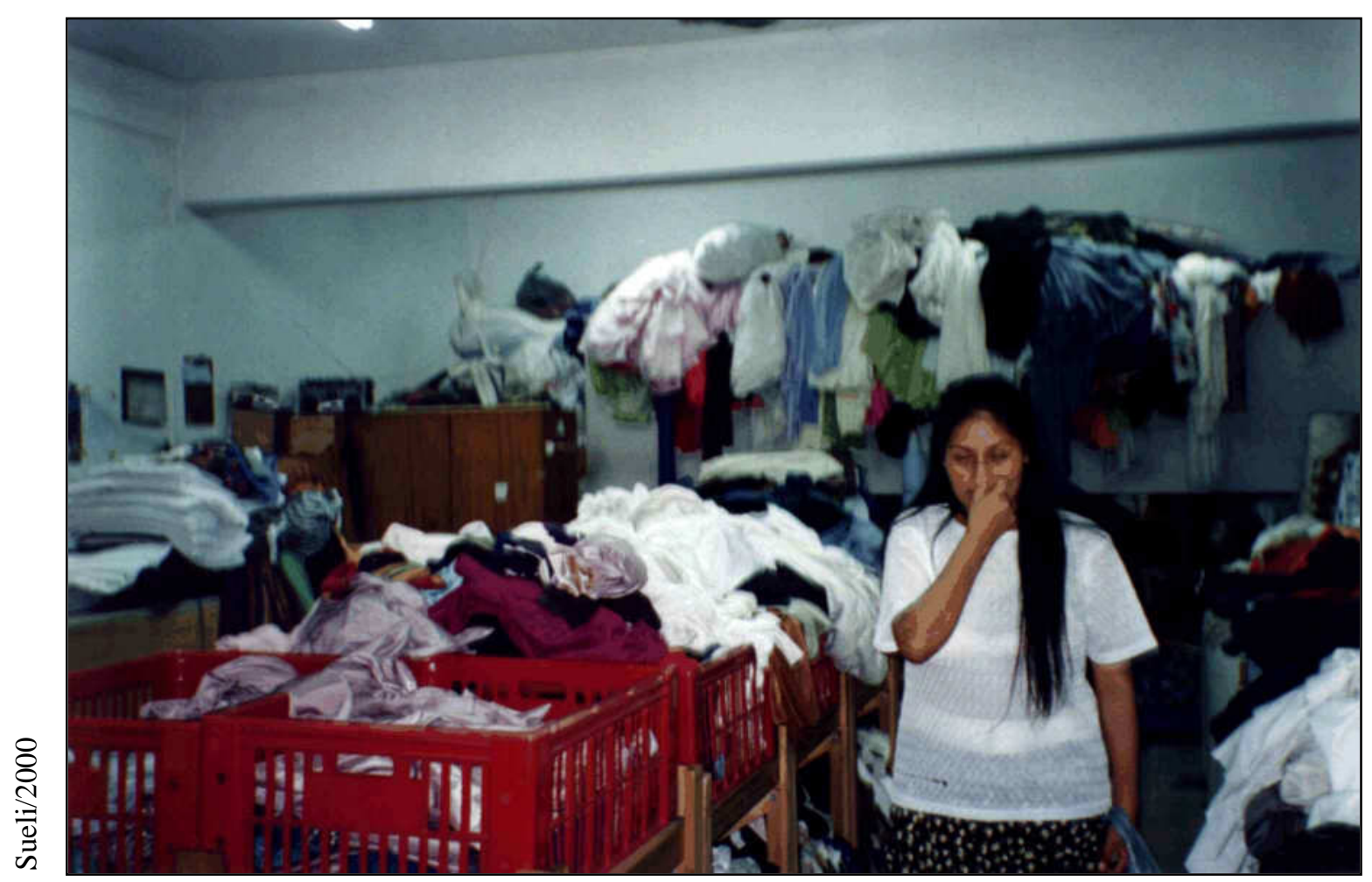

Foto 42: As costureiras e sacoleiras são parte dos compradores desses retalhos. Na foto vemos uma boliviana em uma das lojas

Há empresas que compram os resíduos para utilizá-los no estofamento de veículos. Outras empresas enviam os resíduos para Santos, onde essa matéria-prima é industrializada, e assim transformada em estopas, denominada de pastel. Esse "pastel" é usado na limpeza dos navios. A indústria de estopas é então, uma das grandes consumidoras desses resíduos. Uma parte dos resíduos serve as fábricas de estopa, que se localizam em São Paulo e a outra parte vai para Guaratinguetá, para abastecer a indústria de Cobertores. Atualmente, quase todo o resíduo permanece em São Paulo. 


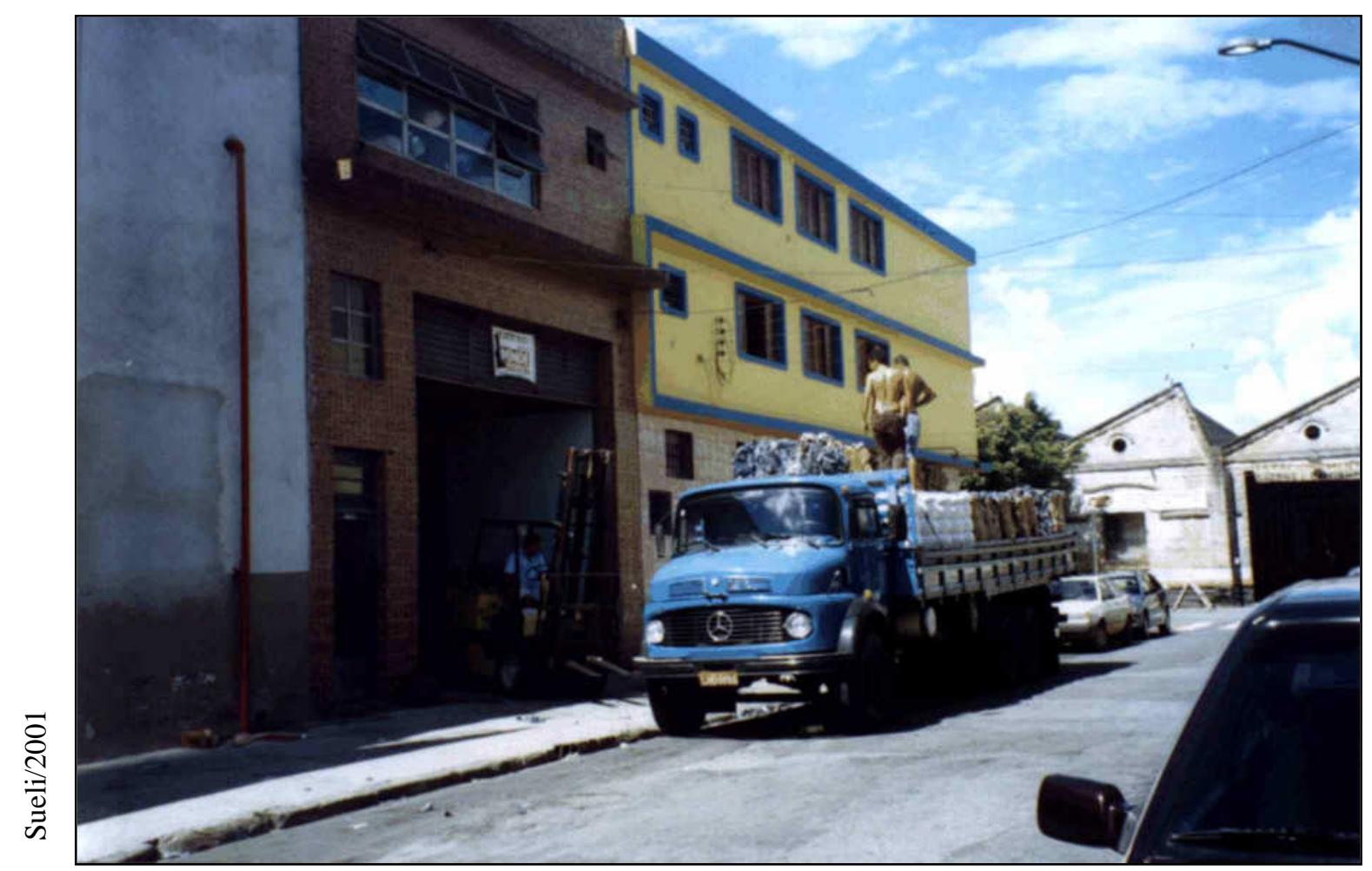

Foto 43: Esse depósito de resíduo também fornece para Recife e Santa Catarina. Esse material será transportado em fardos nos caminhões.

Segundo os depoimentos, o Nordeste contribui com a maior participação nas compras de retalhos. Só a cidade de Santa Cruz do Capibaribe - PE consome cerca de $80 \%$ dos retalhos do Brás. Os retalheiros e a transportadora afirmam que saem do Brás, diariamente; aproximadamente de 5 a 6 caminhões por dia. Vejamos:

"Mando pra Pernambuco, aqui da Maria Joaquina, assim..., caminhão sai 2, 3, 4, 5, 8, 10 caminhão. Quando tempo tá bom, sai 30 ou 40 caminhão para Santa Cruz, que é o lugar que mais sustenta São Paulo. Uma cidade desse tamanhozinho"... (Sr. Zuca)

Essa mercadoria é vendida em Santa Cruz do Capibaribe para as pequenas confecções que predominam nessa cidade. O retalho é industrializado, e se torna uma confecção (vestuário) de menor custo para toda a população de baixa renda, mantendo assim, por meio do vestuário, o baixo custo da manutenção e reprodução dessa população. Essa confecção de baixo custo, e qualidade 'inferior', é mais conhecida como Sulanca. O retalho e resíduo são fundamentais na produção da Sulanca. O aproveitamento da sobra das indústrias da confecções permite o barateamento das 
confecções, para abastecer a população excluída de um consumo de artigos de luxo, entretanto inclusa no mundo das mercadoria.

Assim, o destino dessa mercadoria retalho e resíduo possui uma grande diversidade e complexidade. Então, resolvemos fazer um recorte e seguir o circuito da mercadoria, optando apenas pelos retalhos, deixando de seguir o destino dos resíduos, que daria uma outra pesquisa. Como o maior consumo dos retalhos é realizado pelos comerciantes de Santa Cruz do Capibaribe - PE, resolvemos seguir essa trajetória.

\subsubsection{O transporte}

O transporte desses retalhos até meados da década de oitenta era feito pelos veículo dos comerciantes de Santa Cruz do Capibaribe. Em face disso, transportava-se um menor volume de retalhos e resíduos. Segundo depoimentos e outros registros quem primeiro começou esse comércio entre o Brás e Santa Cruz do Capibaribe foi o comerciante Noronha, um ex-prefeito da cidade. Em 1963, o motorista de caminhão Fernando Silvestre da Silva (Noronha) investiu "30 contos de réis" para controlar no lugar a revenda de tecidos. Para não correr o risco de perder o estoque feito, resolveu vendê-lo a prazo a costureiras. Começou com armazém de retalhos e vendia por quilo. "Deu certo e a coisa não parou mais." (Noronha, depoimento na revista VEJA 13.12.78).

Esses comerciantes se hospedavam nos hotéis próximos do Largo da Concórdia. Um desses hotéis, na rua Uruguaiana, que pertencia a um português, foi transformado, por seu filho, Zé Luiz, em uma transportadora de retalhos e resíduos, a primeira e a maior do ramo. Apesar de ser filho de português com italiano, e ter nascido em Santana, na cidade de São Paulo, Zé Luiz, apresentava um forte sotaque nordestino, evidenciando a grande presença nordestina no Brás e sua influência na vida dos antigos moradores.

Em um segundo momento desse processo, houve um desmembramento, a partir da transportadora de Zé Luiz e seus ex-sócios em outras transportadoras, que também se localizam na rua Uruguaiana. Ao todo são quatro transportadoras, três delas se especializaram em transportar os retalhos para Caruaru e seus proprietários são de lá. A transportadora de Zé Luiz especializou-se no transporte para Santa Cruz do Capibaribe; além dos retalhos, leva, também, aviamentos, botões e todos os acessórios para a 
confecção. A empresa transporta, fundamentalmente, o retalho e quase nenhum resíduo. Segundo o seu depoimento, existem outras transportadoras que se especializaram em levar tecido brim para Toritama, cidade especializada na confecção de jeans.

Existem duas formas de circulação desse retalho até a transportadora. A primeira é quando o comerciante de Santa Cruz do Capibaribe compra direto nas tecelagens (Vicunha, Alpargatas, Estrela, Tekla ) esta entrega na transportadora, e então segue para Santa Cruz do Capibaribe. A segunda, é quando o comerciante de Santa Cruz, compra nas ruas dos retalheiros, a transportadora vai buscar conforme o indicado e depois segue para Santa Cruz do Capibaribe.

Em meados de 1980, os retalhos passam, em maior quantidade a serem enviados para Pernambuco, por intermédio de caminhões. Atualmente, saem em torno de 5 ou 6 caminhões por semana do Brás para Santa Cruz. Cada caminhão leva, cerca de 60 toneladas, então somam, aproximadamente, de 300 a 360 toneladas por semana de retalho. São mil e duzentas toneladas mensais de retalhos exportados de São Paulo para Santa Cruz do Capibaribe.

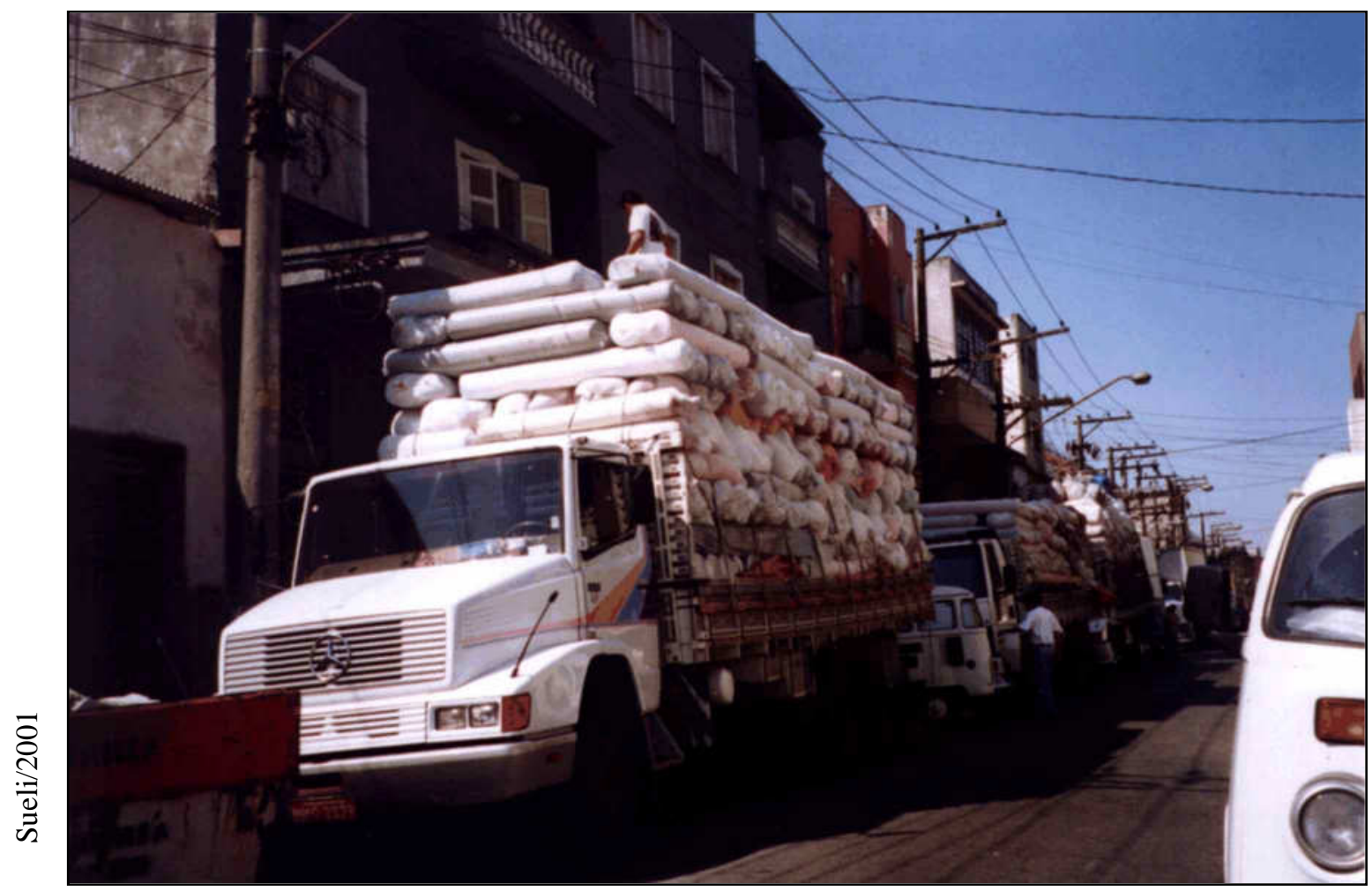

Foto 44: Os caminhões que transportam os retalhos, saem da rua Uruguaiana, sede das transportadoras. 
A transportadora de Zé Luiz atende a vários comerciantes-confeccionistas e atacadistas. Cada caminhão que saí, normalmente está atendendo, por volta de 35 comerciantes-confeccionistas. $\mathrm{O}$ custo do frete gira em torno de $\mathrm{R} \$ 0,22$ o quilo (vinte de dois centavos o quilo). Segundo Zé Luiz, o preço é inferior ao desejado, atribui esse valor devido à concorrência. Ele será pago pelo destinatário. O negócio do transporte é realizado, quase que totalmente, por telefone. A transportadora tem a responsabilidade de pegar a mercadoria nas lojas, depósitos e indústria de tecelagem e levar para Santa Cruz do Capibaribe. Esses caminhões pertencem aos "agregados", autônomos, que vão até a transportadora "pegar o serviço". Assim, a transportadora vai articular essa circulação entre Santa Cruz do Capibaribe e o Brás. No total são 50 caminhoneiros. Podemos concluir que o processo de terciarização, não passa apenas pelo grande capital, mas também, pelo pequeno capital.

Eles levam os retalhos e retornam para São Paulo com outras mercadorias. Em geral são frutas da época, por exemplo, o abacaxi e o coco, outro tipo de mercadoria é o gesso, de Trindade-PE e até mesmo a sulanca que será comercializada nas lojas do Brás e Bom Retiro. O maior fluxo dessa mercadoria ocorre no final do ano, enquanto diminui nos primeiros meses. $\mathrm{O}$ maior problema enfrentado pela transportadora, segundo os depoimentos, é o roubo de mercadoria, quando saem da metrópole, na Rodovia Presidente Dutra e entrando no estado de Pernambuco, realizado por quadrilhas organizadas.

Esses caminhões serviram, muitas vezes, como meio para transportar os migrantes da região próxima de Santa Cruz do Capibaribe para São Paulo. Hoje, inversamente, segundo Zé Luiz, muitos pedem para retornar com os caminhões para a sua região de origem.

\subsubsection{Santa Cruz do Capibaribe}

A cidade de Santa Cruz do Capibaribe está situada no agreste de Pernambuco, a 190 quilômetros de Recife. Essa cidade é o maior pólo de confecções de Sulanca no Nordeste. Existe 3000 (três mil) microempresas, são pequenas unidades produtivas e somam-se 100 fábricas de maior porte. A CDL - Câmara dos Dirigentes Logistas de Santa Cruz do Capibaribe registrou 900 lojas concentradas na Avenida João Francisco Aragão e nas ruas do seu entorno, predominando as lojas de tecidos, os atacadistas. 


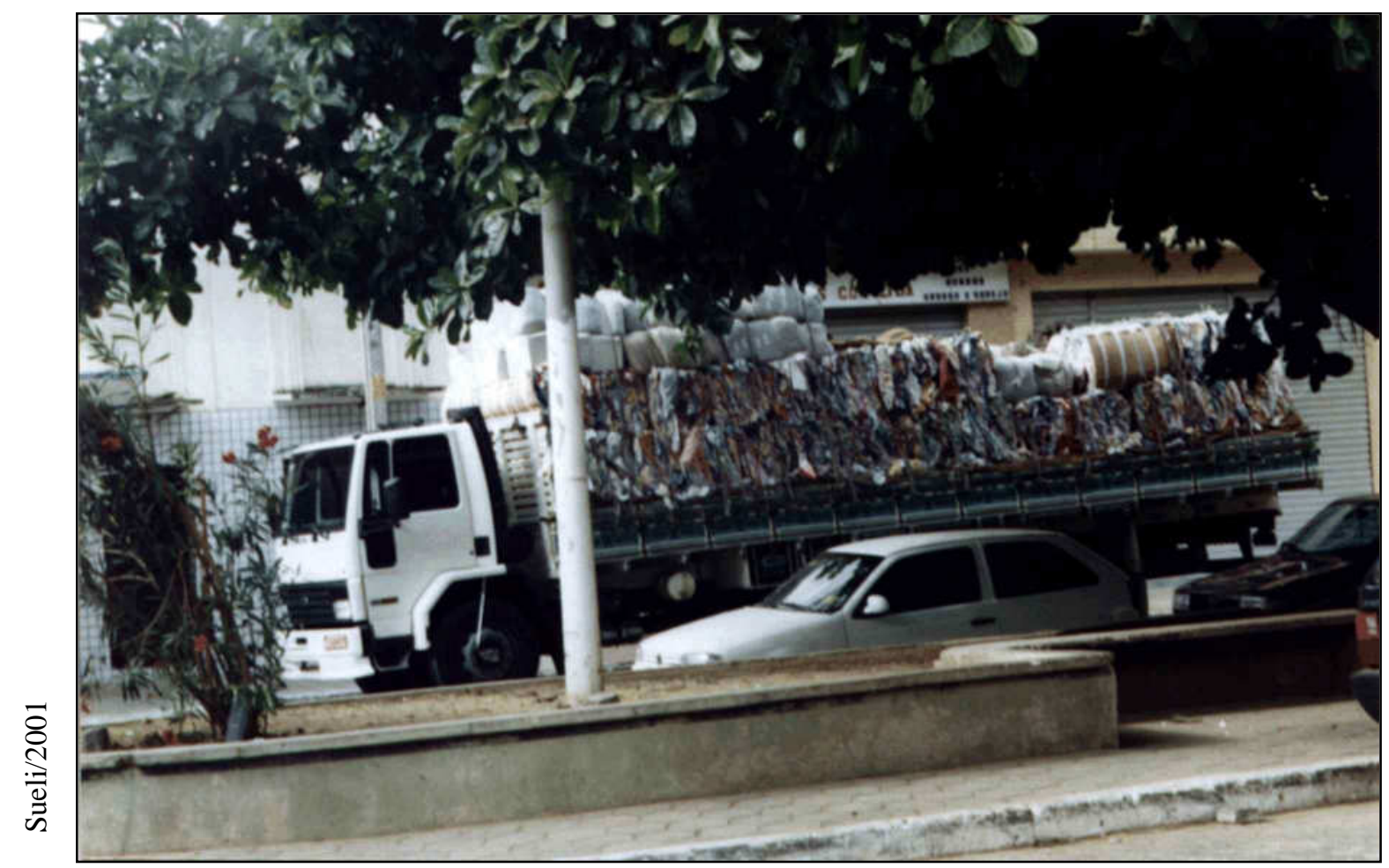

Foto 45: O caminhão que saiu do Brás, em São Paulo, entrega os retalhos aos atacadistas de Santa Cruz do Capibaribe, na Av. Pe. Zuzinha.

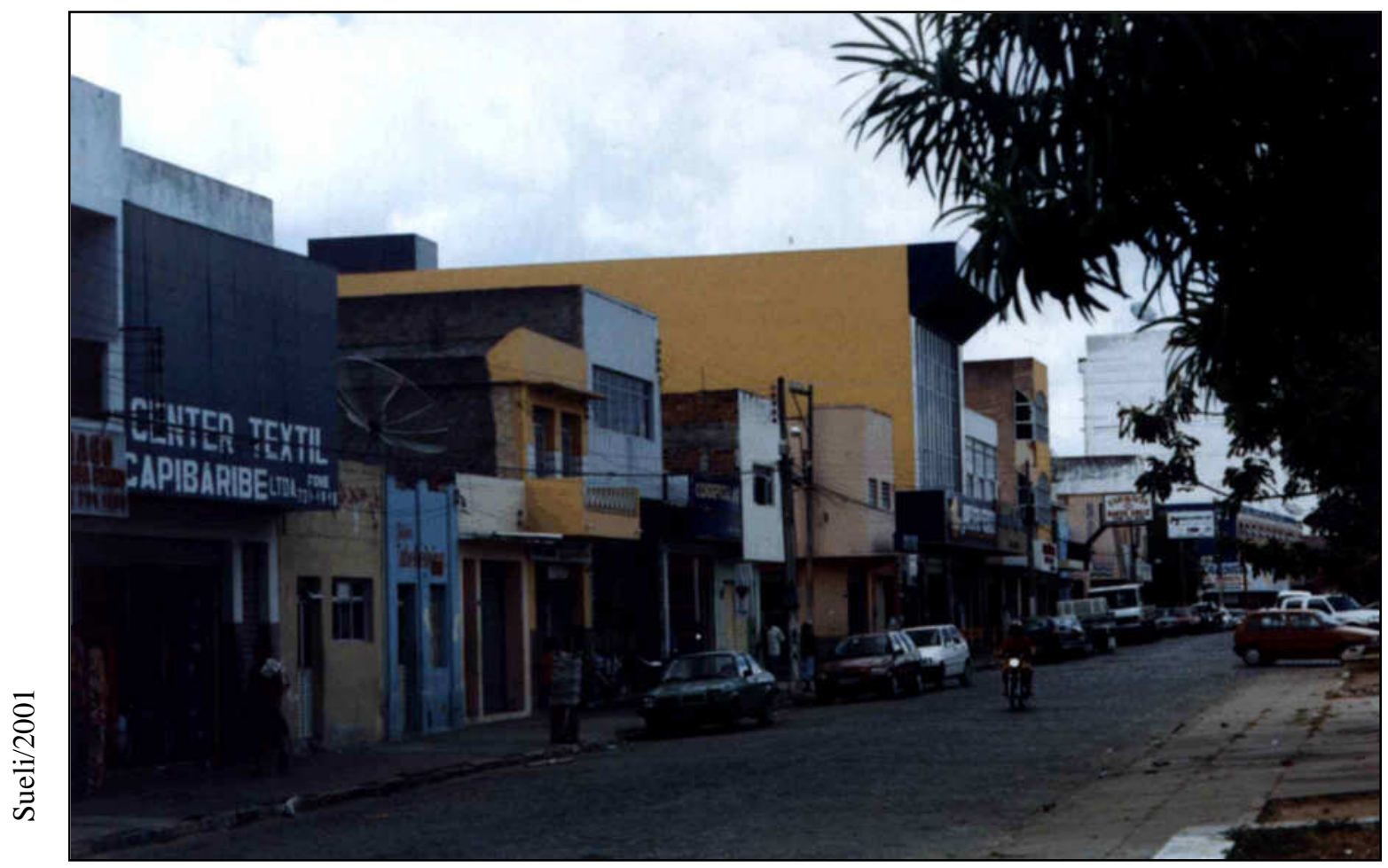

Foto 46: As lojas de atacadistas em Santa Cruz do Capibaribe. 
Esse pólo de confecções nasceu nos anos 1940 e 1950 e desenvolveu-se, principalmente, pós-1960, como observa a pesquisa de CAMPELLO (1983). Nos anos 1940, os tecidos, retalhos, vinham de Recife e a costura era para o uso doméstico.

Os primeiros registros mostram a importância de quatro comerciantes, Manoel Caboclo e Dedé Morais, Pedro Diniz, que no final da década dos anos 50 iam para o Recife vender galinhas, queijo e carvão vegetal, e no retorno traziam retalhos de tecido e o transformavam em colcha, camisa, roupa infantil., conforme afirma SOUZA (1996). Eles possibilitaram uma maior oferta de tecidos, estimulando uma maior intensificação dessa economia. As costureiras da cidade ajudavam, aumentando as sua renda. Depois essas passam a ser abastecidas com retalhos, também de São Paulo e Rio de Janeiro.

A primeira fase da evolução é demarcada pela integração comercial com Recife, e depois na fase posterior, a integração de Santa Cruz do Capibaribe, no espaço nacional, com a expansão da rede rodoviária. Os caminhões transportam as pontas de estoque, os retalhos e resíduos das confecções do Brás e Bom Retiro e as levam para Santa Cruz do Capibaribe. Esses pedaços de tecidos viraram roupas de preço mais acessível, atraindo os moradores da região em busca de ofertas de empregos, elevando o crescimento da cidade em 400\%, em relação à 1970. Segundo o IBGE, o censo de 2000 registrou 59.017 habitantes na cidade. Sua taxa de crescimento foi a maior do estado de Pernambuco (5,72\%), conforme o documento do IBGE. "Muitos chagam as se alojar em barracos, formando assim as primeiras favelas em Santa Cruz do Capibaribe” - A Capital da Sulanca. Essa taxa se deve ao grande número de migrantes. Assim a economia da sulanca está mobilizando as pessoas e assim transformando uma parte do agreste pernambucano. Vejamos como está no site da CDL:

"No começo sulanca era só confecção popular, feita de retalhos, em geral coloridos. Para a maioria, trata-se de neologismo formado por helanca (malha vinda do Sul) e Sul. Outra corrente dá como origem do termo uma designação pejorativa ao produto feito de retalhos, algo semelhante à sucata, ferro velho. A sulanca significa hoje todos os tecidos e confecções, fabricados ou comercializados na região de Santa Cruz do Capibaribe. Do termo vieram 'sulanqueiros' e 'sulanqueiras, pessoas dedicadas à confecção da sulanca.” (site: www.sdescc.com.br)

Vejamos o registro dessas mudanças: 
"A compra de retalhos e peças de tecidos, em grande quantidade e a baixo custo, promoveu a acumulação do capital para essas empresas e viabilizou o estabelecimento de armazéns para a venda do produto. A Grande quantidade de matéria-prima que chegava, intensificou a fabricação de confecção de segunda categoria, para ser vendida na feira da cidade e em outros lugares. Expande-se a produção de confecções populares, chamadas de 'sulanca' de qualidade inferior, sem acabamentos aperfeiçoados. $O$ sulanqueiro era o mascate que viajava vendendo confecções populares, versão interiorana do camelô dos grandes centros urbanos.” (CAMPELLO: 1983, 74)

As pequenas oficinas familiares cresceram, e algumas ganham um porte industrial. $\mathrm{O}$ surgimento da feira, atraiu os atacadistas de tecidos, elevando o crescimento urbano e o fluxo na cidade. A base econômica da cidade são as pequenas oficinas 'de fundo de quintal'. Em razão dessa atividade, surgiram outras pequenas atividades econômicas como os carregadores de mercadoria, transportadoras que usam o lombo dos jegues para levar os fardos de roupa de uma lado para outro da cidade. Em 1996, em cada uma, das 11 mil casas da cidade, havia pelo menos uma costureira, de acordo com FURTADO (2001). O artigo deste autor destaca a intensidade da economia informal nesta cidade; seus dados indicam que dois terços dessas confecções não têm CGC. O paradoxo aparece quando é apontada a arrecadação dos impostos pela prefeitura; o chefe da agência da Secretaria da Fazenda de Pernambuco afirma que é arrecado apenas 1\% do valor real, em 2000 essa arrecadação foi de 3,6 milhões de reais. A prefeitura não apresenta uma infra-estrutura compatível ao seu crescimento urbano, alegando o 'problema' da informalidade'. Por outro lado, o autor ressalta a geração de empregos que essa economia produz. Outro desdobramento do comércio da sulanca, é ampliação da criação de asininos, pois estes são os responsáveis pelo transporte das mercadorias comercializada; assim como os outros serviços que se formam em torno da feira.

A compra dos retalhos em São Paulo é realizada pelos atacadistas, que têm uma maior capacidade de acumulo de capital, CAMPELLO (1983), caracteriza-os, da seguinte forma:

“...esse grupo de atacadistas detém a exclusividade das compras de tecido no Sudeste do país, principalmente em São Paulo. O espaço econômico desta 
exclusividade é dividido entre eles de maneira oligopsônica, tornando-se, portanto difícil penetrar neste esquema já montado.” ( $p .80)$

Há uma preferência, pelas microempresas de confecção de sulanca, no uso dos retalhos do que os tecidos em peças; eles são adquiridos por quilo e são mais baratos. A sua baixa capitalização leva essa confecções a procura da diminuição dos custos. Grande parte de sua produção está nas confecções infantis e femininas. Elas podem usar diversas padronagens. Enfim, o uso dessas peças defeituosas, exige a criatividade das costureiras. Essas confecções perdem no aspecto qualitativo, tanto no acabamento como na apresentação. Há uma procura em “... aproximar-se dos lançamentos da moda do Sul do país, levando para os seus usuários uma atualização dos padrões impostos pelos ditames divulgados pelos meios de comunicação,..." (p. 101). A modernização trouxe a difusão da informação e de consumo. A ação da informação, difunde novos modelos de consumo, inspirado nos países ricos, conforme afirma SANTOS (1979). Essa análise nos leva a transpor esse processo para a moda imposta pelo Centro-Sul para os "modelos" de confecção realizados em Santa Cruz do Capibaribe.

Essa autora vai mostrar na sua pesquisa a atividade de confecções em Santa Cruz do Capibaribe e a produção deste espaço. Na sua pesquisa encontramos um elo com a nossa pesquisa, em São Paulo. Ela apresenta em vários momentos a interdependência desses espaços.

Ocorrem outras formas de subordinação da indústria de confecções, em Santa Cruz do Capibaribe, a indústria do Centro-Sul, a compra dos equipamentos de produção: as máquinas de costura. Essa forma de subordinação, fruto de um processo de desenvolvimento desigual e combinado, leva Santa Cruz do Capibaribe a se tornar um centro regional de distribuição de tecidos do Sudeste para outros mercados. Um atacadista da cidade faz a seguinte afirmação na pesquisa de CAMPELLO (1983):

“...Santa Cruz é depósito de São Paulo. São Paulo industrializa e Santa Cruz. revende. (...) Santa Cruz é pano!”.

A autora continua:

"É um espaço que se relaciona diretamente com São Paulo, estando apenas fisicamente localizado em Pernambuco, mas suas relações comerciais estão estreitamente ligadas ao sudeste do país, pelo lado do abastecimento da matéria prima." (...) "Por outro lado, através do processo de comercialização, 
esse espaço se relaciona com todo o Nordeste e ainda com Estados das regiões Norte e Centro-Oeste do país. É justamente nos Estados de maior pobreza e de grande área rural ou semi-urbana que as confecções de Santa Cruz do Capibaribe, penetram de modo mais intenso, o que vem corroborar o dizer de um entrevistado, que '... quanto pior, melhor', ou seja, quanto mais pobreza, mais se vende as confecções chamadas sulancas." (p. 128)

Assim, constatamos a interligação desses espaços, que formam uma rede de mercadorias e homens. Santa Cruz do Capibaribe recebe o 'refugo' das indústrias têxteis de São Paulo, e o Brás, é o nó que interliga o outro nó que é Santa Cruz do Capibaribe, que redistribui essas mercadorias, na perfeita racionalidade que a modernidade impõe.

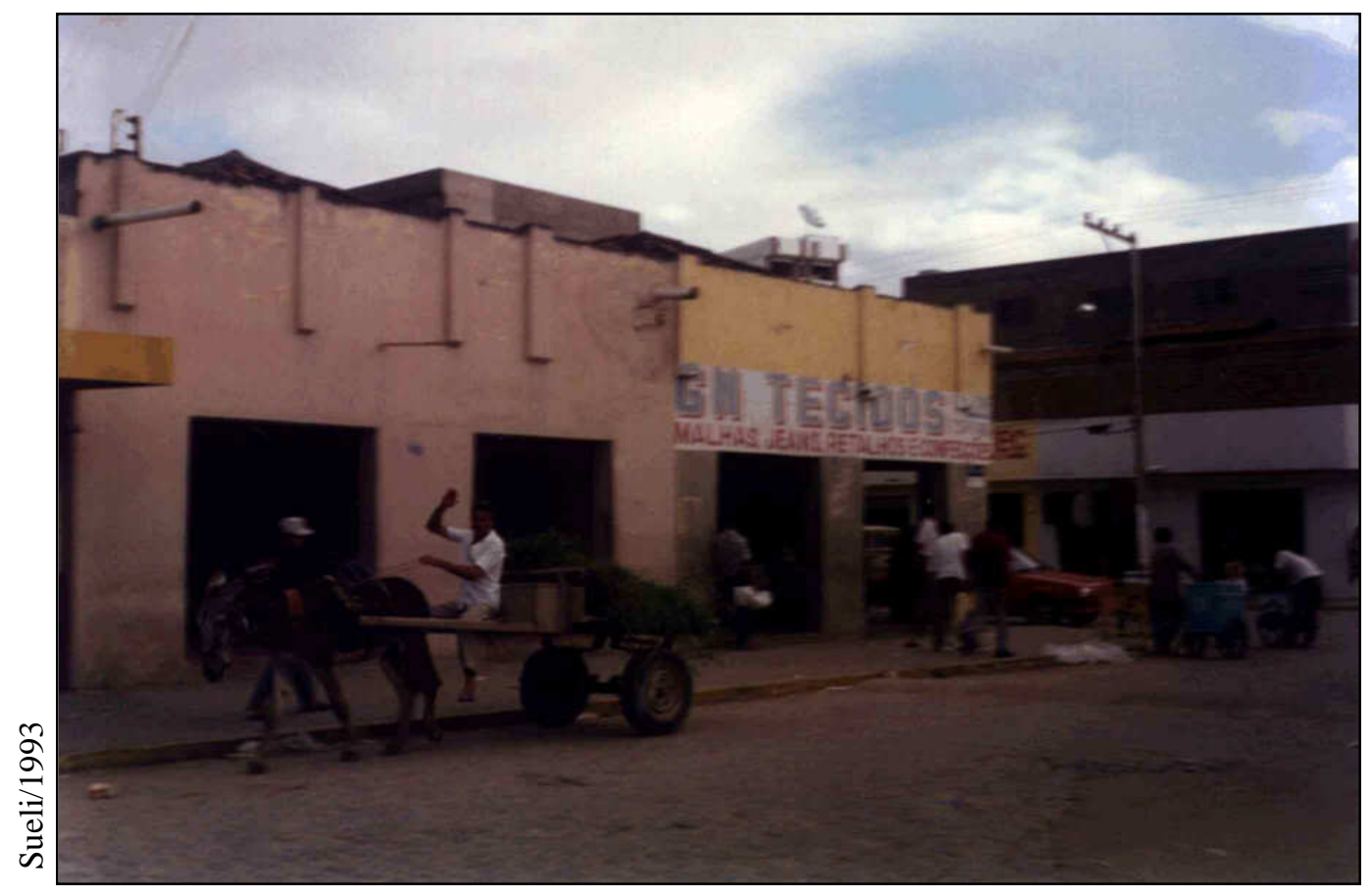

Foto 47: Santa Cruz do Capibaribe em 1993, loja dos atacadistas. 


\subsubsection{Feira da Sulanca}

Os caminhoneiros trouxeram, nos anos 60, para Santa Cruz do Capibaribe a helanca, então um dos tecidos da moda no Sul do país. Segundo SOUZA (1996) existem três versões para o termo Sulanca:

“A primeira refere-se a uma corruptela das palavras do 'sul' e 'helanca' para determinar a 'helanca que vinha do sul'. A Segunda liga-se a um episódio que ocorreu entre um comerciante que transportava as mercadorias e um fiscal governamental. Quando solicitado a apresentar a documentação dos produtos que transportava, o comerciante teria se referido pejorativamente aos mesmos como produtos de baixa qualidade, chamando-os de SULANCA. O fiscal aquiesceu na obrigatoriedade de documentação e este de fato rapidamente se tornou conhecido por todos os que comerciavam com aquelas mercadorias. Todos passaram a utilizar a denominação pois ela significa a não ocorrência de portes tributários. Uma terceira versão não aponta elementos mais precisos, tendo a denominação vindo a ser utilizada por todos apenas para determinar os produtos locais que ficaram conhecidos como simbolização de produtos simples e de baixa qualidade." (SOUZA et al., 1996: 17)

Uma forma mais simplificada seria o destaque da combinação do Sul e a helanca originando o termo. A sulanca seria a confecção de menor qualidade, voltada para a população de baixa renda. As entrevistas de CAMPELLO (1983) definem sulanca, como, "mercadoria de combate, de grito, de pobre, de camelô". O cordel de Isaura de Oliveira, ex-sulanqueira, de Panelas - PE, apresentado no início deste capítulo três, vai representar o contraste dos vestuários, como bem de consumo, e as diferenças e desigualdades sociais e o seu poder de consumo.

Existe uma conexão de Feiras da Sulanca, envolvendo algumas cidades. A primeira feira surgirá em Santa Cruz do Capibaribe, nos anos 70. Depois, em 1983, aparece outra feira em Caruaru, somando-se a tradicional Feira de Caruaru, que tem 160 anos. E mais recentemente, em fins dos anos 90, a cidade de Toritama, também, organiza a sua feira. Ainda temos registro de Feira da Sulanca em Aracaju, Recife, Palmares, João Pessoa, Maceió, Paulo Afonso e Calumbi (SOUZA, 1996), Fortaleza, Tobias Barreto, conforme depoimento de motorista dos ônibus de sacoleiros. Essas 
feiras formam uma rota, para os feirantes, que levam a mercadoria do pólo da região de Santa Cruz do Capibaribe. Existe até os dias da semana ordenados da seguinte forma: segunda-feira, ocorre a feira em Toritama; na Terça feira, em Caruaru e na Quarta-feira em Santa Cruz do Capibaribe. Essa feiras são as mais significativas por suas especificidades.

A feira de Santa Cruz do Capibaribe e mobiliza 20 mil pessoas entre camelôs e sacoleiros. Ela acontece às terças-feiras, segundo FURTADO (2001) e é denominada Feira da Sulanca. Ela se inicia na noite anterior e encerra à tarde. A história do aparecimento da Feira em Santa Cruz do Capibaribe é registrada por CAMPELLO (1983) desse modo:

"Através das entrevistas realizadas foi possível saber que esta feira surgiu por uma iniciativa individual. Numa madrugada de uma $5^{a}$ feira no ano de 1979, uma costureira, sabendo da presença de uns viajantes na cidade, foi exibir suas confecções na calçada da sua rua, num gesto de desespero diante de suas dificuldades financeiras. Este exemplo passou a ser imitado por diversas sulanqueiras que passaram a exibir suas mercadorias também nas $5^{a s}$ feira. Sabe-se que a presença dessas sulanqueiras começou a incomodar os comerciantes locais, que ameaçavam expulsá-las, argumentando que a exibição de suas mercadorias iria prejudicar suas vendas. Apesar das diversas ameaças, as sulanqueiras, insistiram, instalaram-se em bancos e conseguiram o apoio da Prefeitura." (CAMPELLO: 1983, 75)

Os feirantes de vestuários, na sua maior parte, são os próprios sulanqueiros, que levam a sua produção. Uma pequena parte revende a mercadoria, trabalhando em um sistema de consignação. A feira de Santa Cruz do Capibaribe reúne predominantemente os sulanqueiros da própria cidade, mas também em menor número de Toritama e Caruaru. Nas outras cidades e feiras, o quadro modifica-se.

Os compradores são de toda parte do país; FURTADO (2001) ainda faz referência a presença de paraguaios e bolivianos. Esses compradores chegam em ônibus 'apinhados'. A feira de Santa Cruz do Capibaribe é composta por 7 mil barracas, que ocupam 20 ruas da cidade, correspondendo 25 mil metros quadrados do leito das ruas. A paisagem é caótica e além da imagem, há o som caótico. Esses sentidos são registrados por FURTADO (2001): 


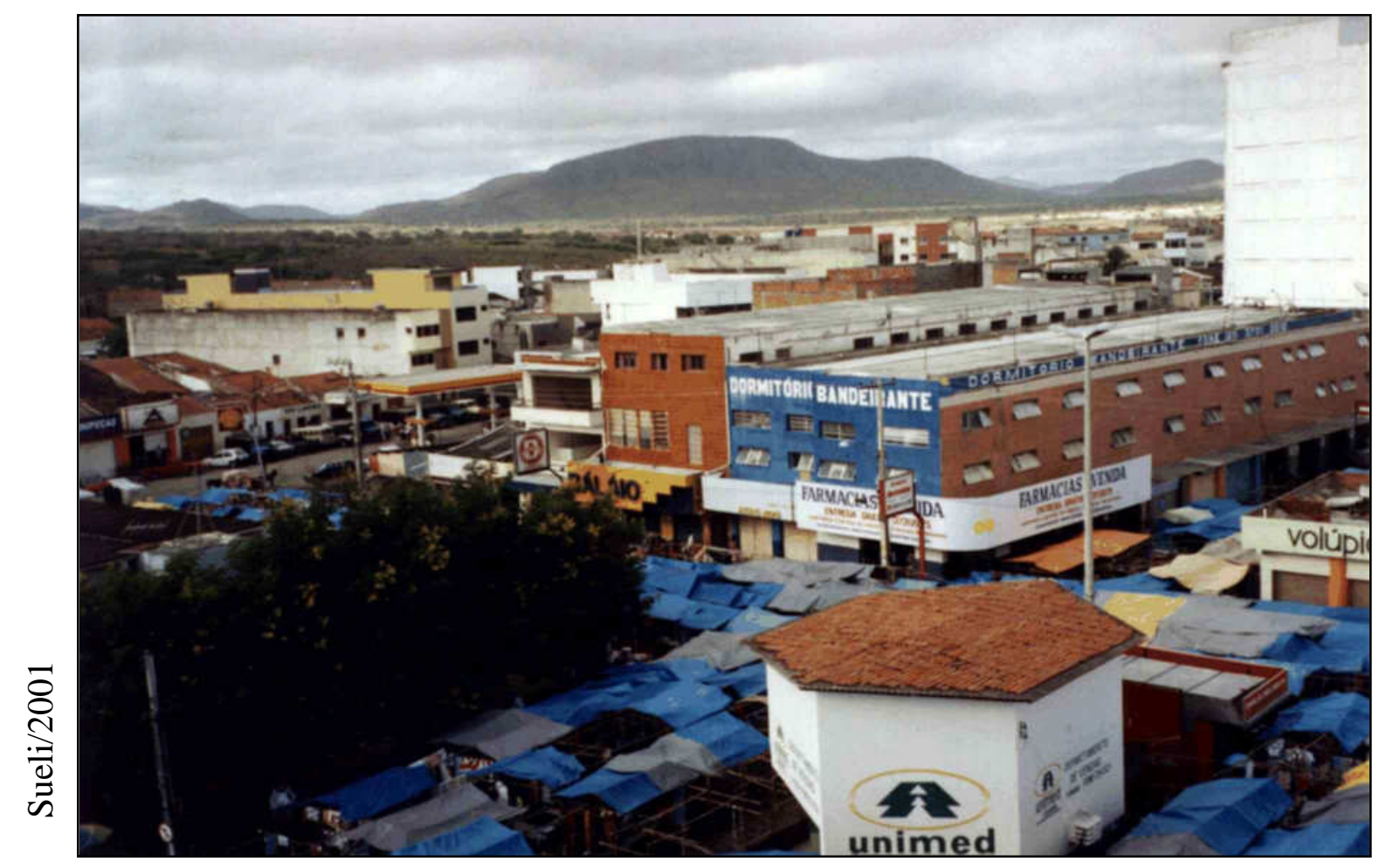

Foto 48 : A Feira da Sulanca de Santa Cruz do Capibaribe. Ao fundo uma das 50 (cinqüenta) pensões denominadas de dormitórios, para alojar os compradores.

“A começar pela balbúrdia. Os sotaques se chocam no ar quando o barulho do serviço do alto falante bate de frente com o dos CD players, dos rádios e dos aparelhos de TV dos ambulantes.” (...) “Em busca de melhores ofertas, os clientes precisam desviar dos carregadores que puxam carrinhos de construção civil por entre cerca de 6.000 bancas".

A infra-estrutura da feira é precária e a coleta de lixo é quase inexistente, agravando o caos, aqui registrado. Mesmo assim, os índices contrariam a precariedade da organização. A frequiência anual é de aproximadamente um milhão de compradores, estimando um movimento em torno de 450 milhões de dólares por ano, conforme FURTADO (2001). O preço da mercadoria é o grande atrativo, a peça de vestuário, que apresenta o maior valor, não chega a $\mathrm{R}$ \$20,00 (vinte reais) Vejamos as últimas ações da prefeitura na Feira da Sulanca de Santa Cruz do Capibaribe, encontrados em um documento enviado à ASCAP pelo antigo secretário Hélio Lima Aragão (11.06.2001) 
que podem nos servir como indicadores, para dimensionarmos o tamanho da feira, mas que diferem dos dados de FURTADO:

- Cadastramento de Feirantes: 8.450;

- Cadastramento dos fretistas de carroça anual - 600 fretistas;

- Cadastramento dos proprietários de bancos de feira: 75 proprietários;

- Retirada de feirantes que vendiam mercadoria no chão - 1800;

- Retirada dos feirantes que vendiam mercadoria em carroças manuais - 300 feirantes;

- Abertura de 5 novas ruas na feira de confecção;

- Abertura de 2 ruas exclusivas para venda de confecção no chão (caso especial);

- Abertura de 2090 novos pontos para o comércio de confecções;

- Disk Feira e Mercados;

- Aquisição de 600 Kits (colete, bonés, crachás) com o comércio local e para os fretistas de carroça manual;

- Bebedouro, pintura das ruas, criação de carga e descarga;

- Pesquisa de ônibus que visitaram a feira de confecções no semestre - 1920, com média de 30 passageiros, 57.600 visitantes;

- Contagem de carros de porte médio que visitaram a feira no semestre, totalizando 1.440 automóveis com média de 10 passageiro, no total 14.440 compradores;

- Contagem dos sacoleiros nos 6 meses de feiras - 72.000 sacoleiros;

- Colocação de 40 banheiros químicos ao redor da feira.

São cerca de três mil sacoleiros que gastam em média $\mathrm{R} \$ 500,00$ (quinhentos reais) na feira. A feira movimenta em torno de 6 milhões reais mensais, segundo o Secretário da Indústria, Comércio e Turismo de Santa Cruz do Capibaribe. A Feira além de comercializar a sulanca, também possui uma rua com artigos do Paraguai.

No dia da feira os hotéis e dormitórios ficam cheios, os feirantes revezam no funcionamento de suas bancas, uns domem na própria banca, para tomar conta da mercadoria. A Feira inicia na segunda-feira com poucas bancas funcionando. Uma parte dos feirantes estão em Caruaru, quando encerra a feira em Caruaru, eles rumam para Santa Cruz do Capibaribe. O movimento maior da feira é na terça-feira, à noite, gira a madrugada e encerram na quarta-feira. Ainda na quinta feira, tem uma rua que é 
ocupada com as bancas $\mathrm{O}$ sulanqueiro que vende tudo na terça-feira, nem abre no dia seguinte.

Existem muitos jovens meninos que auxiliam os sulanqueiros, os sacoleiros a carregarem as mercadorias. Os ônibus ficam estacionados em três pontos diferentes da cidade, no entorno da Feira. Um ponto é a avenida Pe. Zuzinha, que é ocupada em quatro fileiras de ônibus. O outro ponto é próximo da Câmara dos Vereadores. Esse é um bairro nobre da cidade, com grandes mansões. Mesmo com a recente infraestrutura cedida pela Prefeitura, observamos ainda pessoas fazendo suas necessidades fisiológicas nas ruas e um grande lixo deixado pelos sacoleiros nesses espaços. Geralmente, eles estacionam sempre nos mesmos pontos e próximos, conforme a sua origem. $\mathrm{O}$ início da Av. Pe. Zuzinha estão os ônibus do Espírito Santo e Maranhão. No fim dessa avenida ficam os ônibus do Rio Grande do Norte. Na Câmara dos Vereadores ficam os ônibus do Pará e da Bahia (Av. Siqueira) e assim por diante.

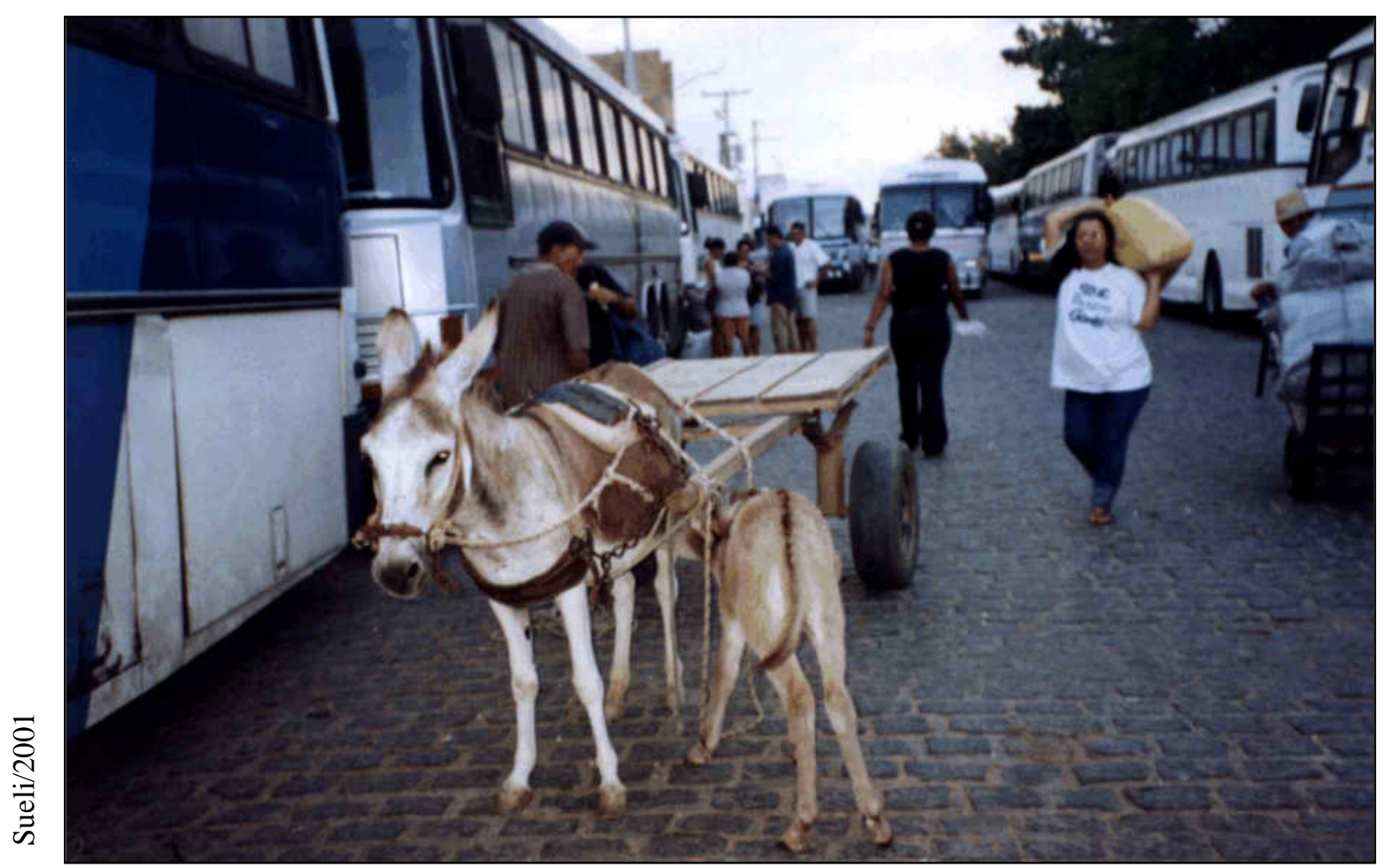

Foto 49: A Av. Padre Zuzinha ocupada pelos sacoleiros do Norte e Nordeste. Em primeiro plano os jegues, meio de transporte muito usado em dia de feira.

Alguns compradores de sulanca que vêm dos lugares mais distantes, passam dias em Santa Cruz do Capibaribe. São pessoas de Rondônia, Manaus, e até da Grande São 
Paulo. Eles alugam uma garagem e depositam suas compras, ficam de 8 a 10 dias na cidade e compram tanto da feira como das lojas. O Sr. Antonio, sulanqueiro, exemplificou em seu depoimento o caso de um cliente de Manaus que levou 15 blusas femininas e depois retornou levando 300 unidades.

Nos tempos áureos (anos 80 até 85) Santa Cruz do Capibaribe recebia 200 ônibus semanalmente, principalmente, Norte e Nordeste. Depois com a Feira da Sulanca de Caruaru e Toritama, a cidade teve que dividir esse fluxo de sacoleiros. Hoje, recebe em torno de 100 ônibus. Geralmente os feirantes, que também chamamos de barraqueiros ou sulanqueiros são as próprias pessoas que confeccionam na suas casas - denominada por eles normalmente de " fabrico" ou por nós de "oficinas de fundo de quintal". Esse é o caso de Nalva. A sua família está trabalhando na oficina, enquanto ela e seu irmão são responsáveis pela montagem da banca. Uma hora ela atende, enquanto o seu irmão dorme. Depois que termina a feira ou a sua mercadoria vão para o "fabrico" para ajudar a família. Seus clientes na maioria pagam à vista e a dinheiro, os mais antigos, de confiança abrem o nome na caderneta e fazem cheque. Os seus pais eram das proximidades do município, depois migraram para uma cidade, divisa com o Piauí, onde ela nasceu. Há dez anos migraram para Santa Cruz do Capibaribe mobilizados pela indústria da sulanca. Entre os sulanqueiros encontramos muitas histórias de migração. Ouvimos, também, histórias de retorno de São Paulo, mobilizados pela indústria da sulanca. Encontramos, também, alguns migrantes que estão em Santa Cruz do Capibaribe há menos de dois anos, vieram da área rural. O Sr. Zé, diferente de Nalva, trabalha por consignação. Ele tem o seu filho para ajudar na banca, trabalha com a sulanca, em consignação da fabrica em que seu filho trabalha como bordador. No período manhã ele ajuda na feira e à tarde (das 14:00 às 22:00) trabalha na fábrica. Ele ganha $10 \%$ em cima da mercadoria vendida. Eles migraram há dois anos de Jataúba (PE), município próximo. Há sulanqueiros de Caruaru e Toritama na Feira de Santa Cruz do Capibaribe. O Sr. Antônio conta como conseguiu o ponto:

"Quando o sujeito não paga, como esse que fazia 5 meses que não pagava; o fiscal me deu um toque e eu comprei o ponto dele, pois ele não queria mais." (Antonio) 


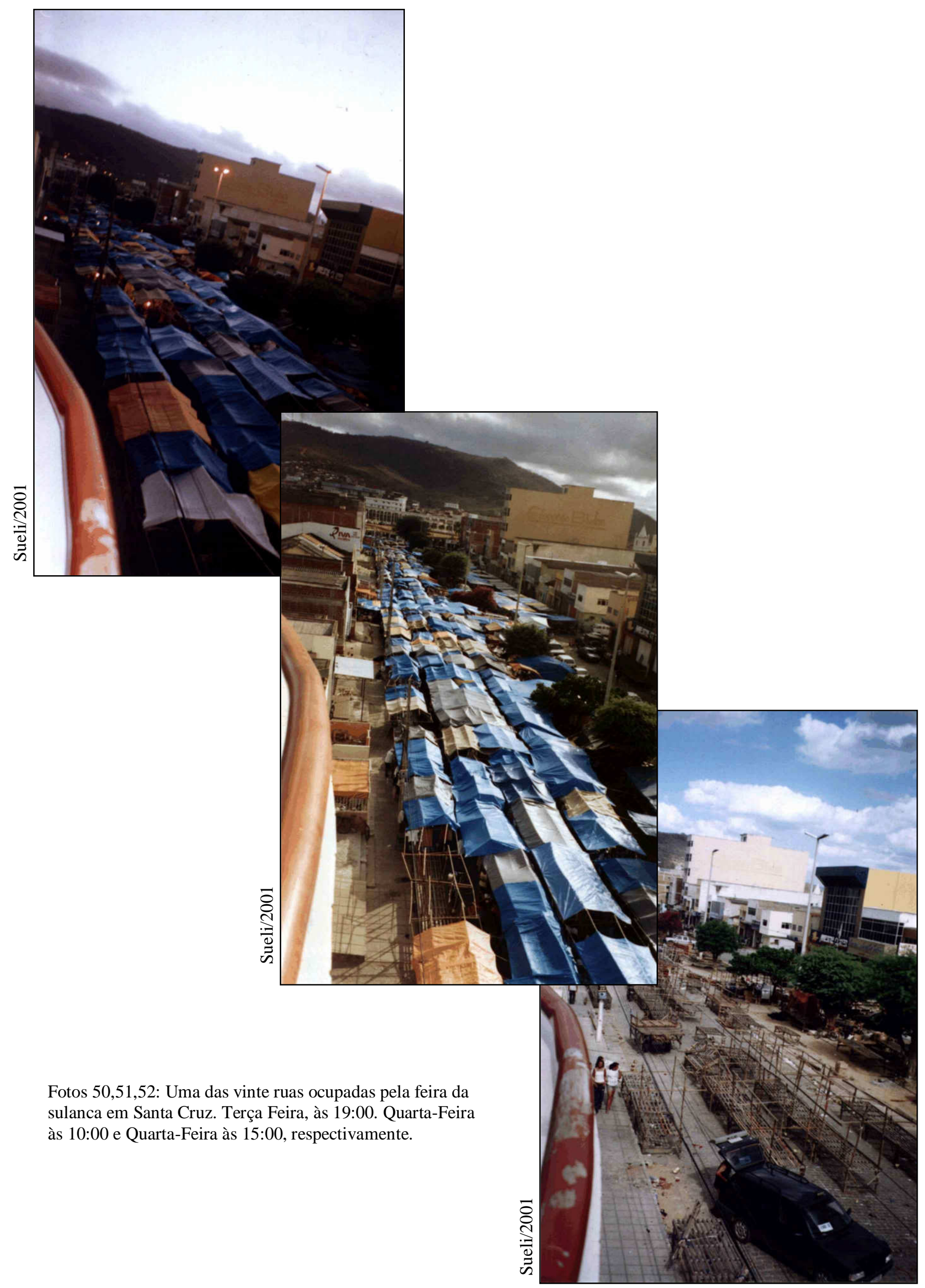




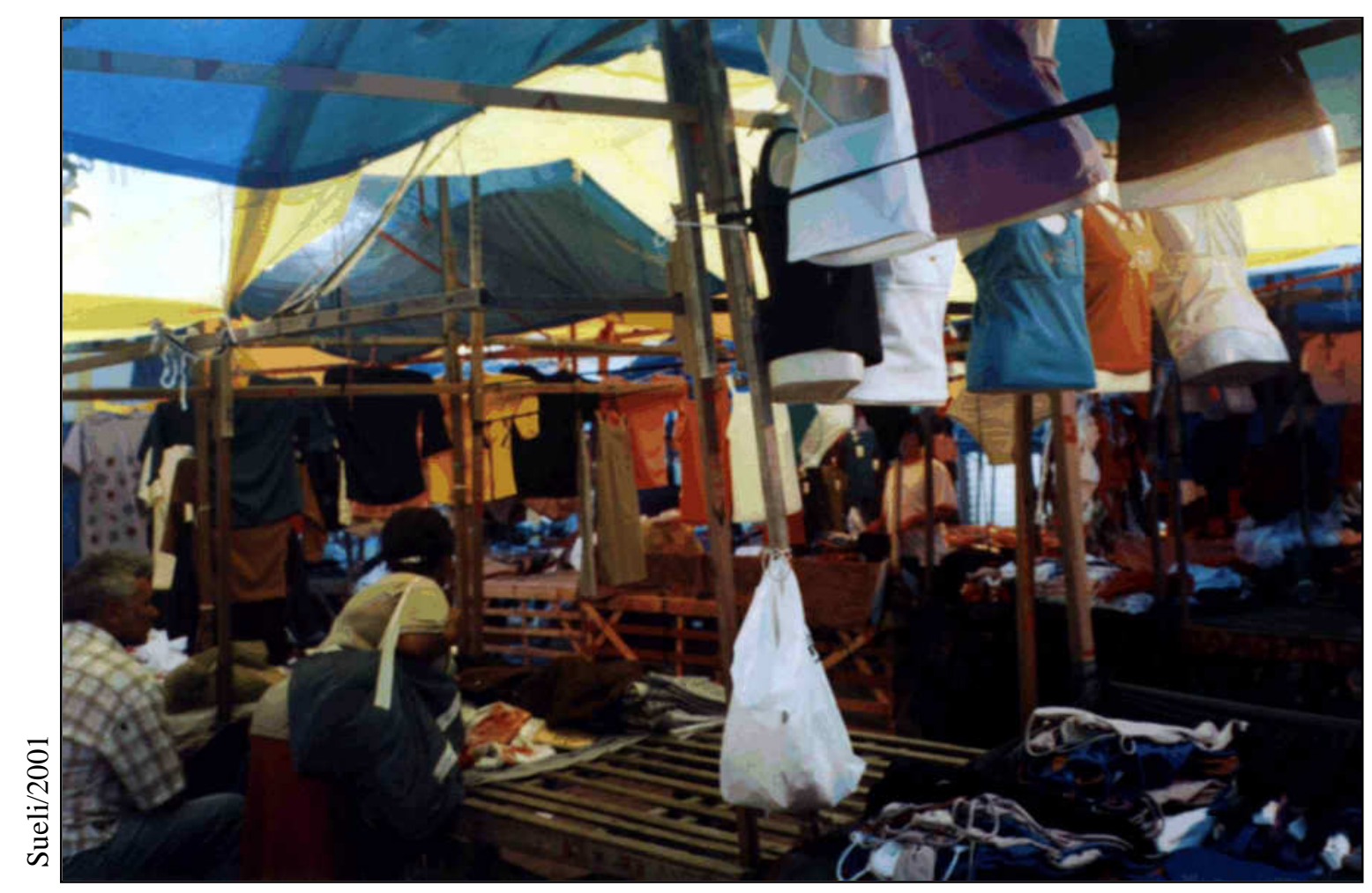

Foto 53: Feira da Sulanca de Santa Cruz do Capibaribe.

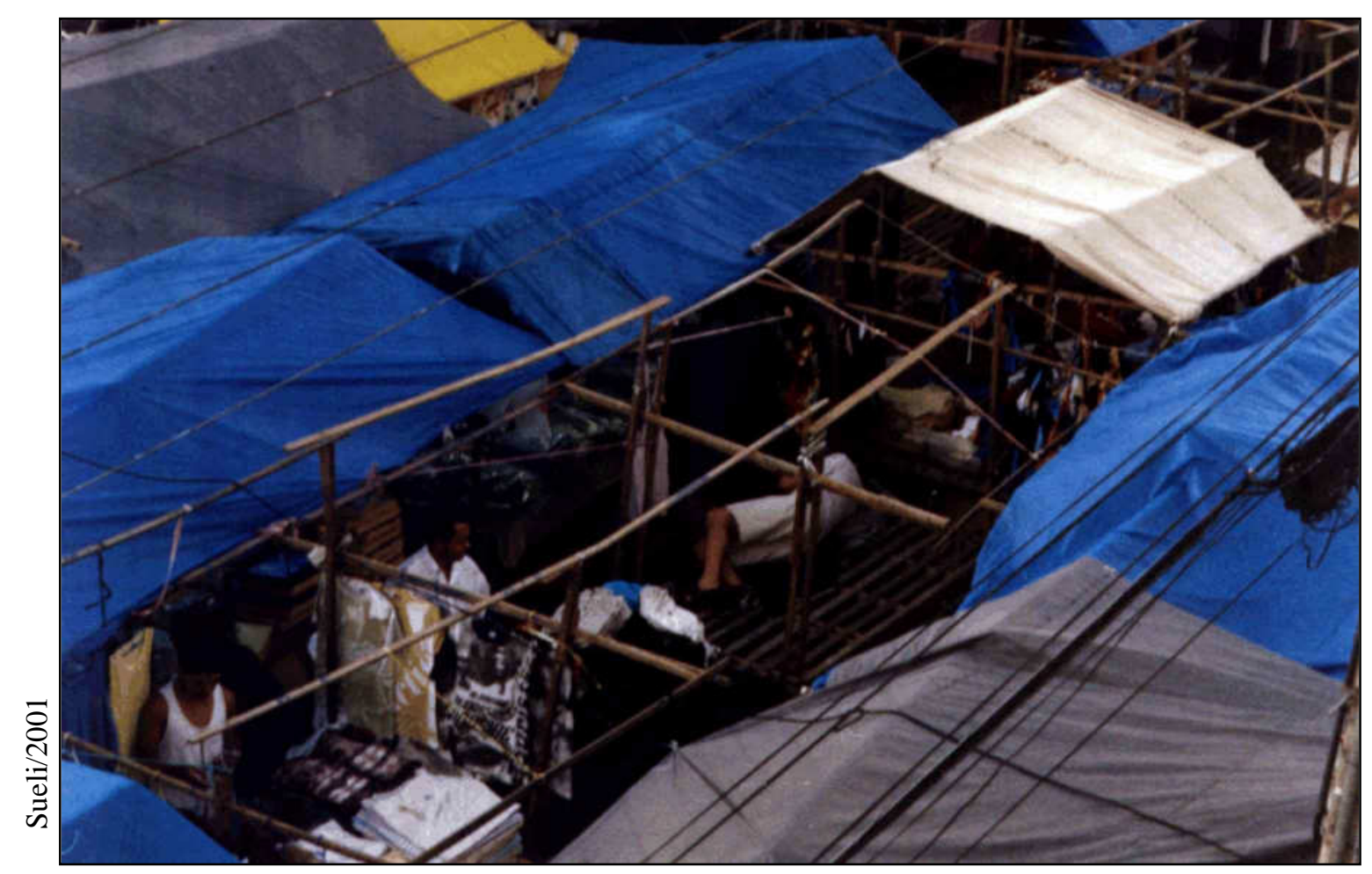

Foto 54: Sulanqueiro dorme em sua barraca. 
Existem na feira, algumas bancas de colchas de retalho, que registram o início da história da sulanca. São as permanências. Essas colchas são ainda muito procuradas para serem revendidas nos armazéns do Norte e Nordeste. Outro uso para essas colchas são na montagem das barracas, tanto na cobertura, para amenizar as altas temperaturas, nos dias de calor, pois os toldos de plástico aquecem muito, quanto para forrar a barraca para depositar a mercadoria. O terceiro uso apontado nessas colchas é para a secagem do arroz no Maranhão.

O Sr. Naldo trabalhava na agricultura e há dez anos passou a trabalhar na confecção. Possui dez pessoas que costuram suas colchas, nos sítios do Município Brejo da Madre de Deus (município vizinho de Santa Cruz do Capibaribe) e uma outra pessoa vende na Feira de Caruaru sua mercadoria. Seus clientes são oriundos de quase todos os estados: Amapá, Roraima, Piauí, Pará, Maranhão, Paraíba e até Rio de Janeiro e São Paulo como ele citou. Sua clientela predominante é a população carente. Vende em torno de 2 a 5 mil peças. Encontramos os feirantes vendendo a colcha a $\mathrm{R} \$ 1,50$ e uma velha costureira de Brejo vendendo diretamente na feira por $\mathrm{R} \$ 1,20$. Seu Naldo conta que caiu o movimento. Um cliente que comprava 2 mil peças, hoje compra apenas 1 mil. Uma redução de 50\%. Ele fala de crise. Também, atribui essa queda das vendas à concorrência, aumentou o número de vendedores de colchas.

As bancas de madeira são alugadas, e o proprietário é responsável pela montagem e desmontagem da feira. Esse trabalho é realizado com a ajuda dos jegues que transportam várias barracas ao mesmo tempo. Essas bancas são de madeira, padronizadas e tem uma cobertura de toldo azul, predominando. Um dos problemas enfrentado na feira são os cheques pré-datados sem fundo trazendo prejuízos para o sulanqueiros. O número de roubos em Santa Cruz do Capibaribe é menor do que em Caruaru, cidade maior.

Há uma estrutura que foi sendo criada em razão da feira, como os 50 dormitórios e 6 hotéis, que recebem os sacoleiros todas semanas, além de funcionarem como um depósito de suas mercadorias. Nesses dormitórios eles alugam a cama e não o quarto, barateando ao máximo o custo para o sacoleiro.

A nova gestão do Prefeito José Augusto Maia tanto formulou ações que excluem os que saem da ordem estabelecida com o termo "Retirada de Feirantes" visto no documento anterior, como aponta tentativas de organizar "o desorganizado". Há ações também que buscam apoiar os compradores - sacoleiros. Essas iniciativas são todas 
muito recentes, segundo Lúcia Gomes de Oliveira, uma das autoras da publicação Sulanca (1996). A última ação da prefeitura foi a transferência das ruas de Santa Cruz do Capibaribe para o Parque, que dista quatro quilômetros da cidade. Nessa política para a feira, houve a mudança do secretário, e Jaciel P. da Silva assumiu a pasta no dia 26.11.01, na semana de inscrições dos boxes no novo projeto da Feira da Sulanca (realizamos uma entrevista no dia 28.11.01). Essa transferência ocorrerá dentro de um ano, aproximadamente. Esse projeto vem causando muita polêmica na cidade. Para Lucia Gomes de Oliveira com o tempo, aqueles que são contra e se opõem ao projeto serão obrigados irem para o Parque. Os lojistas se opõem a mudança, pois perderão a freguesia. O projeto Parque das Feiras de Santa Cruz do Capibaribe ocupa uma área de $48000 \mathrm{~m}^{2}, 6000$ mil box, 430 lojas, 70 lanchonetes, 10 restaurantes, postos (policial, bancário) e uma área de estacionamento para todos os veículos particulares e ônibus para excursão. (Jornal da Sulanca, novembro de 2001). A prefeitura com o apoio do Banco do Brasil, que com os recursos financeiros que virão do FAT (Fundo de Amparo ao Trabalhador) irá ajudar os feirantes comprar os seus boxes, que custarão de $\mathrm{R} \$$ 500,00 a R \$ 3.200, 00. São 12 milhões de reais, 250 reais o metro quadrado.

A ASCAP (Associação de Confeccionistas de Santa Cruz do Capibaribe) é uma entidade que possui 100 associados, na sua maioria lojistas. Sua funcionária disse que a maioria dos sócios acham boa a mudança para o Parque. Os pequenos sulanqueiros, que vendem no "balaio", não têm condições de pagar um box e são contrários as mudanças. No Parque é permitido que se adquira apenas um box, diferente da situação atual em que há sulanqueiros que possuem 3 a 4 bancas. Assim esse novo espaço, administrado pela prefeitura, vai controlar a especulação, mas também será um entrave para o sulanqueiro descapitalizado. Outra ocupação que fica comprometida são aqueles que trabalham com o aluguel das bancas, a montagem e a desmontagem da feira, transporte das barracas. 


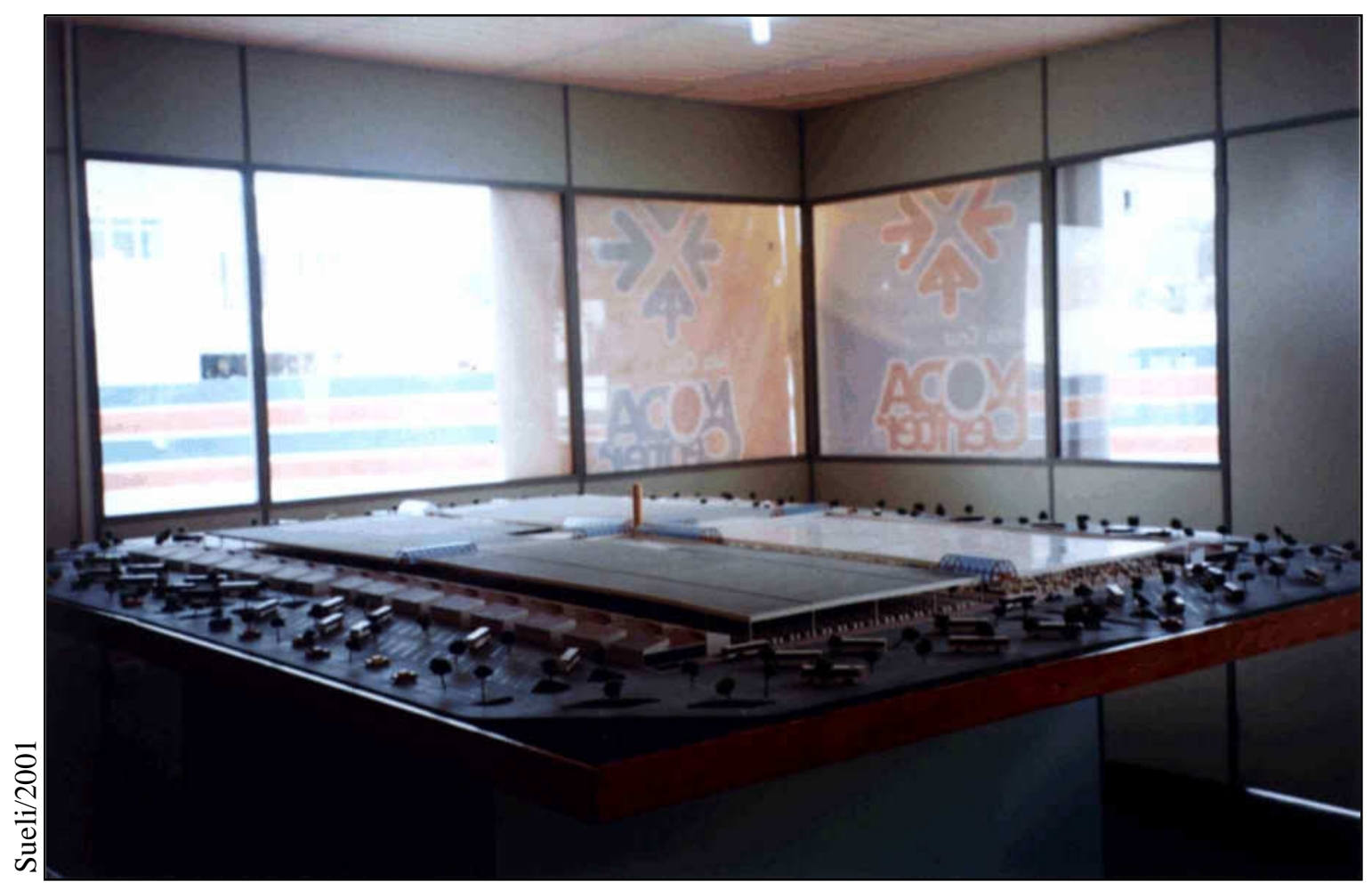

Foto 55: Maquete do projeto "Parque das Feiras" em Santa Cruz do Capibaribe.

Outra Feira, que alcança grandes proporções, é a Feira de Caruaru, já cantada por Luiz Gonzaga, nos anos 50, período em que sua população rural era muito maior que a urbana, então, o espaço da feira atendia, principalmente, a essa população. Recuperamos a dinâmica da Feira de Caruaru, hoje denominada Feira da Sulanca, a partir do depoimento de Isaura, ex-sulanqueira que se tornou cordelista, migrou e veio declama seus cordéis em São Paulo. Entre seus cordéis, ela registrou as dificuldades dos sulanqueiros e a dinâmica da Feira, esses cordéis se encontram em anexo. Na sua entrevista, ela me explica como é a Feira e o que é a sulanca:

“... Eu tava em Caruaru eu trabalhava no comércio e achava muito bonito aquela feira da Sulanca e eu cheguei a uma conclusão que eu também tinha que ser uma comerciante de sulanca, achava muito bonito, mas depois e eu achei que era um sofrimento muito grande, naquela feira, tinha que ir de madrugada...?” (...) “A Feira começava de noite, era 7 horas da noite e ia até na sexta feira duas horas da tarde. Então eu vendia camisa, vendia sutien na feira da sulanca, eu botava em monte de sutien aqui no braço e ficava gritando - Olha o porta turbina! Quem vai querer o porta 
turbina! Então, eu tinha muito conhecimento nesse tempo e chegou um certo tempo que eu fui a decadência, acabei com tudo que tinha,... tinha comércio, então..."

“Eu pegava de fabricantes, que era um amigo meu. Eu pegava vendia?... depois eu prestava contas a ele aquele lucrinho era pra mim. Eu pegava camisa também de um firma muito grande de Caruaru. Vendia na feira. Depois, o lucrozinho era pra mim. Eu prestava conta e assim toda terça-feira, toda segunda feira, vendia esse negócio. Aí chegou um tempo que eu comprei umas camisa com meu dinheiro. Vendi. A feira da sulanca é uma feira composta por mais de 10000 bancos. Sabe o que é bancos? Uma banquinha assim, mais de 10 mil. Fora os marreteiros, os camelôs que vendem na calçada, assim. É uma feira é tão grande Para você atravessar a ela, se passa mais meia hora. Só pra atravessar a ela. Andando. É muito grande. Vem ônibus de toda cidade vizinha, entendeu? Então aquela feira é tudo fabricante. As pessoas mesmo que fabricam, levam na feira pra vender mais barato. Nas lojas são muito caros. Então as pessoas preferem ir para a feira da sulanca que lá vai encontrar artigo bom, por menor preço. Sulanca significa artigo de terceira qualidade, como se for o Brás, aqui. Tem as lojas aqui. Não tem os shoppings? são caros. Tudo que você encontra no Brás tem no shoppings e lá, também. Então, você encontra na feira e encontra nas lojas. Mas tem gente lá que é orgulhoso, não vai na sulanca comprar, compra na loja, só pra manter a etiqueta do Brás, prá lá. Só que da loja vem daqui do Brás, pra lá.” (..) “Então, a sulanca é muito grande. Cada um que vende a sua mercadoria, cada um procura vender mais barato. É uma gritaiada tão grande naquela feira. É uma agonia, tanta gente. É mais de 300 ou 500, naquela feira, 1000 ônibus por dia, ali. É ladrão demais ali abordando o povo as pessoas, roubando mercadoria. É uma loucura aquela feira." (Isaura)

“Eu também sou sulanqueira

Fico no meio da calçada

Sentindo aquele cherinho daquela carninha assada

Tem dia que eu não descolo

E volto prá casa sem nada."

(Isaura) 


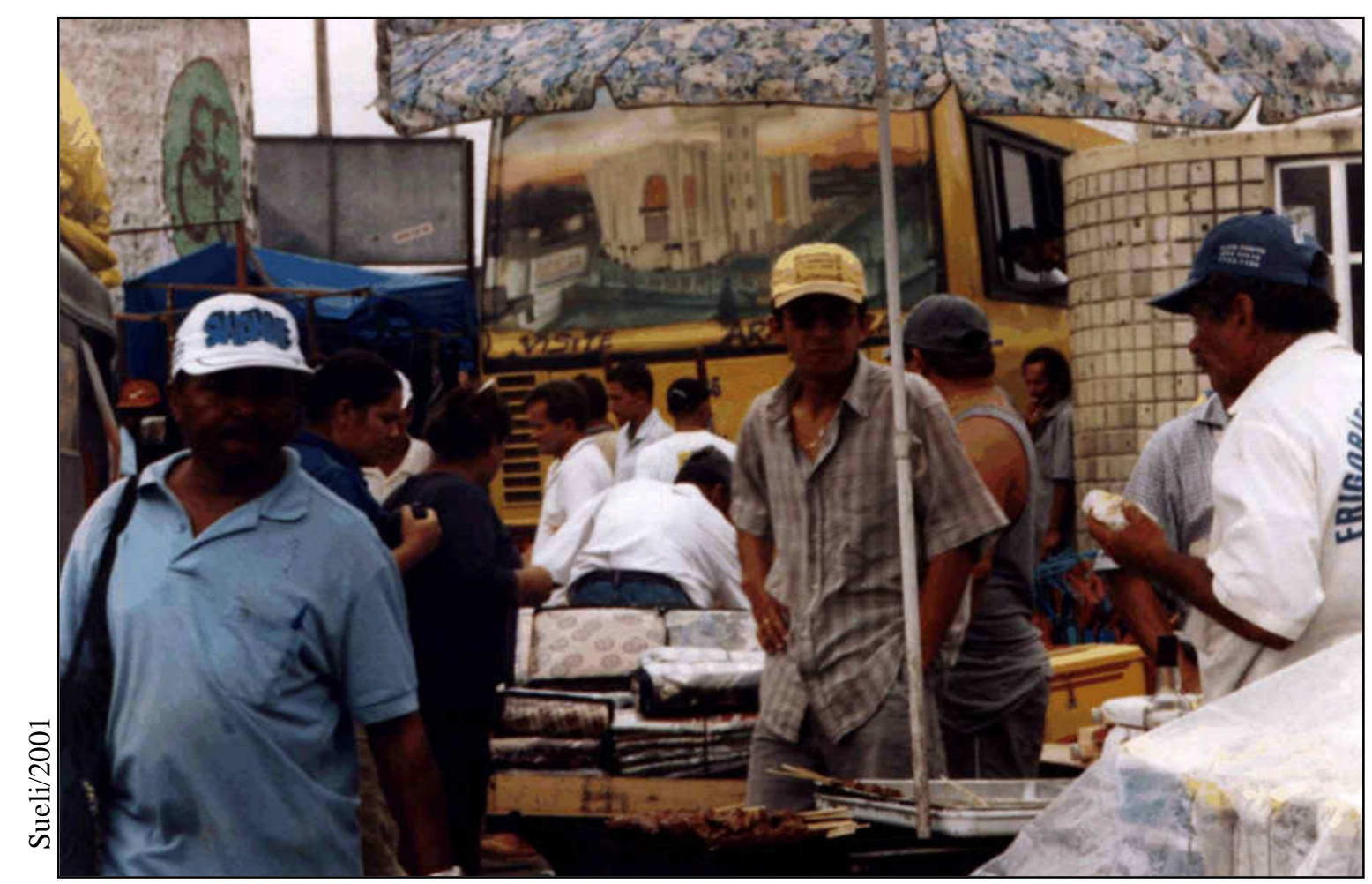

Foto 56: O churrasquinho no estacionamento dos ônibus.

Isaura diferencia Santa Cruz do Capibaribe, por ser uma cidade mais voltada para a indústria de confecções, vestuário, enquanto que Caruaru, é uma cidade comercial. Essa é a imagem que ficou da Feira da sulanca, de nove anos atrás. Segundo alguns registros encontrados em Caruaru, essa Feira atrai semanalmente, dezenas de milhares de pessoas das regiões Norte e Nordeste que vão abastecer-se, de confecções populares para venda, em seus estados. Em dia de feira da sulanca, o estacionamento é ocupado, por mais de 300 ônibus, sem contar os carros particulares e as lotações, que são Toyotas. Existem cinco pontos para estacionamentos e mais as ruas em torno da feira.

A história da Feira de Caruaru se confunde com a história da cidade. “... a feira antecede a cidade, sem ela seria impossível o desenvolvimento do povoado." (SILVA: 1998). José Rodrigues de Jesus doa as terras de sua fazenda Cururu para a construção de uma igreja (1781). A "Feirinha do nada" começou com a troca de gado por cereais realizada por José R. de Jesus. Em 1795 já havia um povoado com mil habitantes e uma feira de gado e produtos de roça, originando a Feira de Caruaru.

Em 1895 houve a implantação da "Estação de Ferro Central de Pernambuco". A Feira cresce com a implantação da ferrovia, pois amplia o seu alcance. A importância da feira se expande com vinda de pessoas das cidades vizinhas, aumentando cada vez mais. 
Segundo Sebastião Monteiro, micro empresário, são 50 cidades em torno de Caruaru. A construção de rodovias fortaleceu esse processo de desenvolvimento da distribuição da mercadoria.

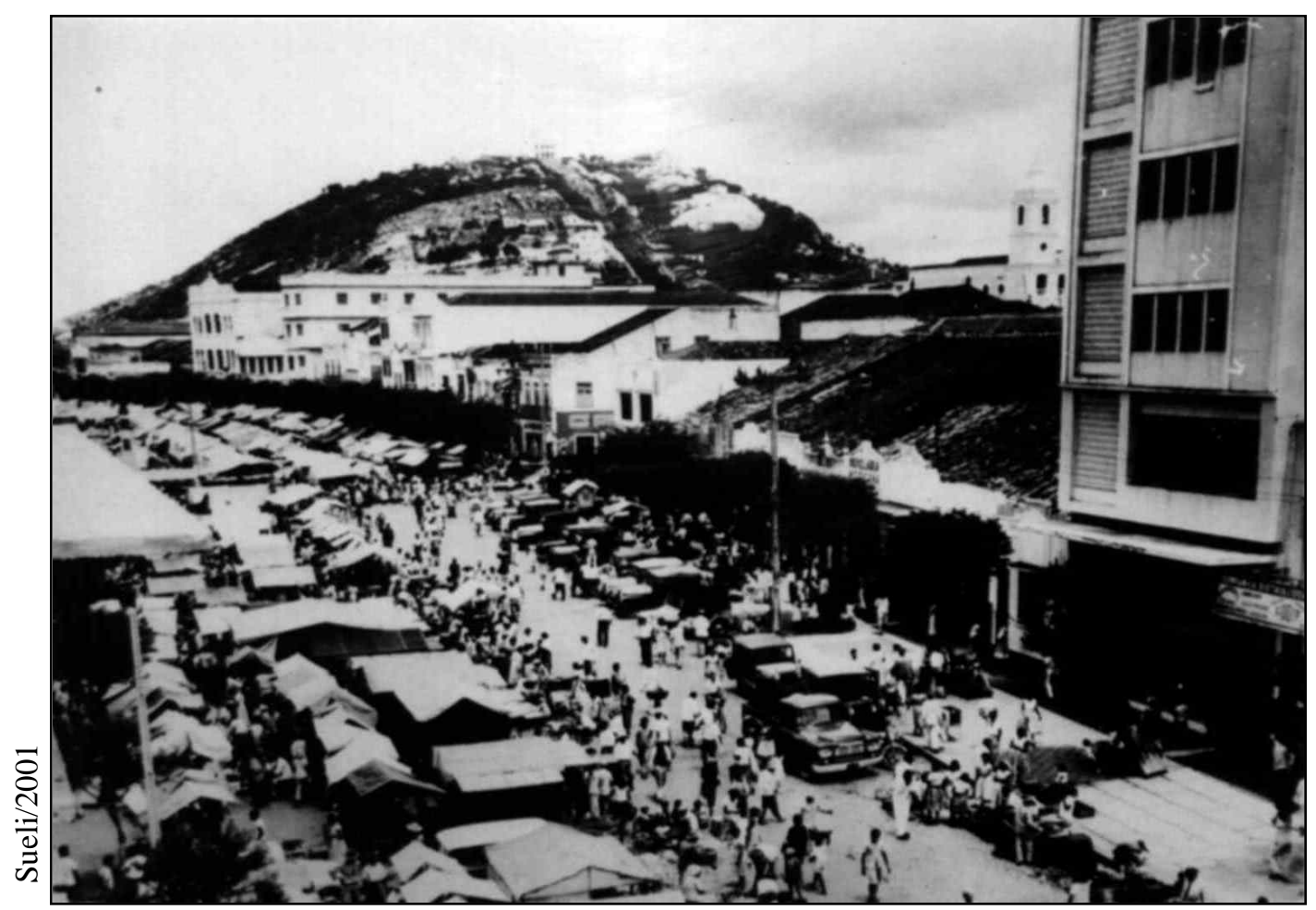

Foto 57: A Feira de Caruaru em 1940.

Fonte: Memorial da Feira de Caruaru/Arquivo Fund. Joaquim Nabuco.

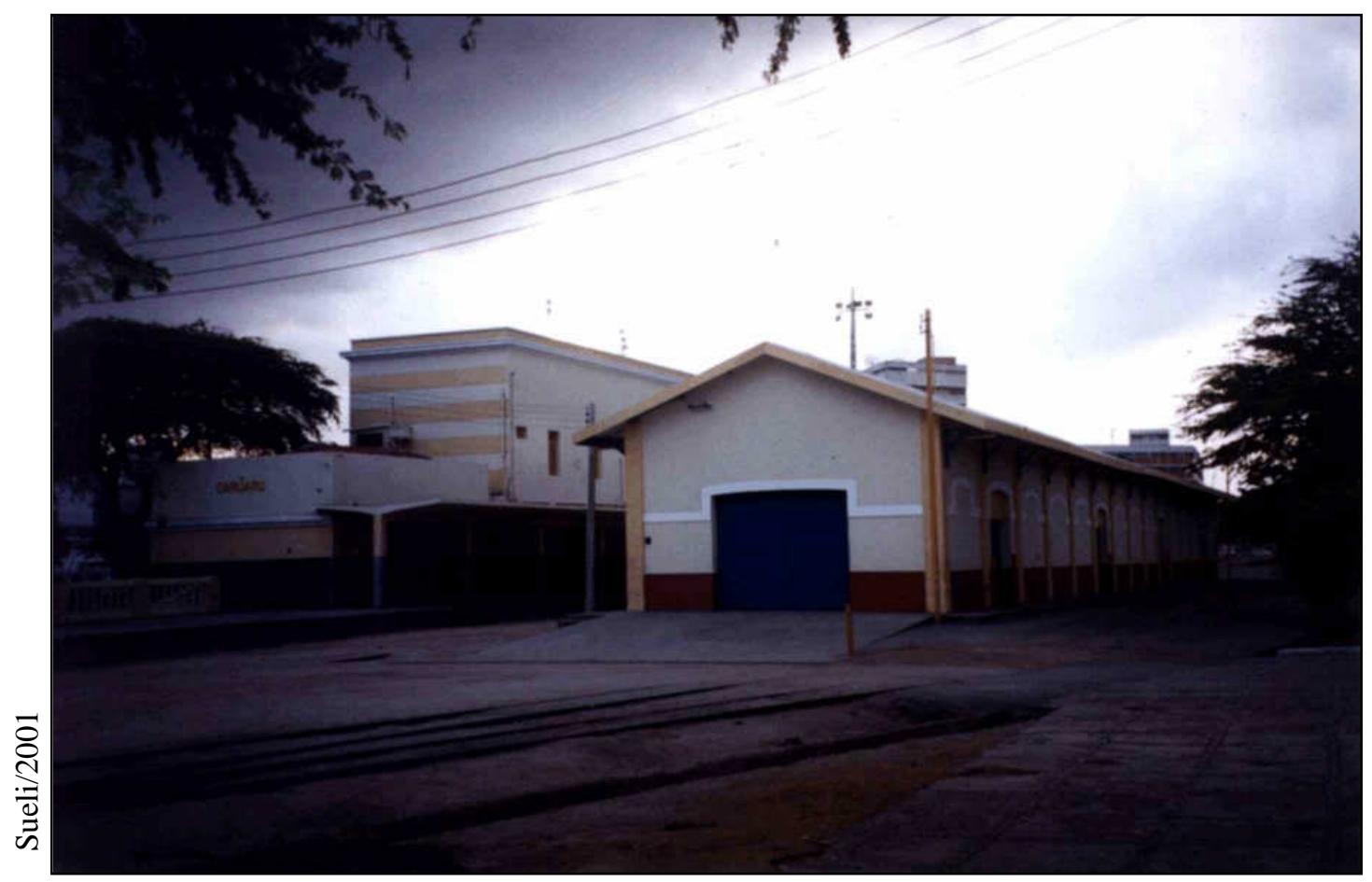

Foto 58: A Estação Ferroviária de Caruaru. 
“Por ser ponto estratégico, Caruaru desde logo passou a possuir um comércio forte e em constante crescimento, pois até as cidades, circunvizinhas escoam seus produtos para lá, onde são mais facilmente vendidos.” (BATISTA DA SILVA, 1998)

A área urbana se expandia e a feira crescia conjuntamente, ocupando o centro da cidade. A feira ocupava ruas, praças, becos, travessas. Localizada, predominantemente, na Rua Quinze de Novembro e ruas próximas. Os primeiros sinais de transtorno já aparecem em 1853, entretanto a sua mudança só ocorrerá em 1992, a partir da decisão do prefeito João Lyra Neto (1989). O antigo "Campo do Monta", praticamente ao lado do centro da cidade, se transforma no "Parque 18 de maio" com 8 hectares, pavimentado, urbanizado e organizado por setores para cada tipo de comércio, estacionamento rotativo para visitantes, plataforma para carga e descarga. Em 1998 eram 6000 bancos, hoje são 12 mil bancas ocupando não só os 8 hectares destinados, mas transbordando para as ruas entorno do Parque, ocasionando um transtorno no trânsito e moradores da região. Os bancos de feira variam de medida, de $3 \mathrm{~m}^{2}$ a $6 \mathrm{~m}^{2}$ ou bancos conjugados, chegam a mais de $9 \mathrm{~m}^{2}$.

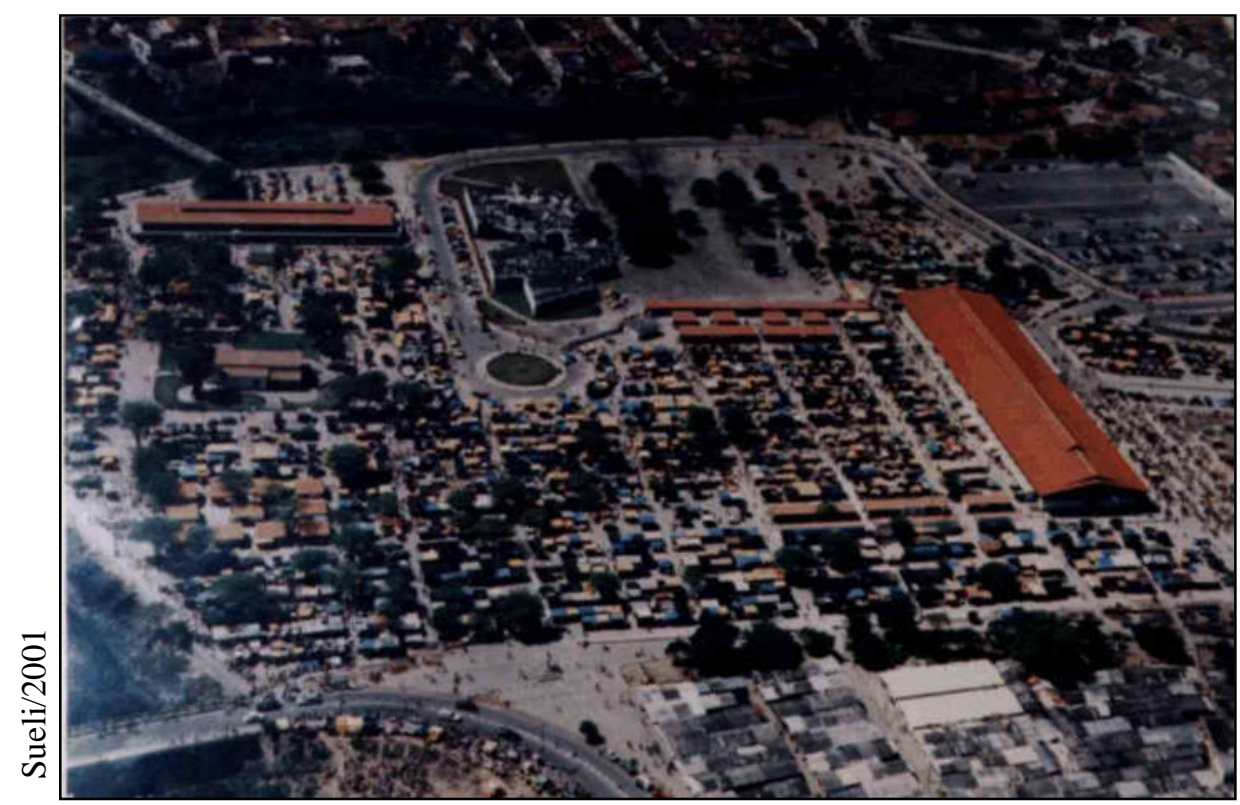

Foto 59:Vista panorâmica da feira de Caruaru em 1992. Fonte: Memorial da Feira de Caruaru. 
A Feira de Caruaru é formada pelo comércio de artesanato, comércio de alimentos, comércio de calçados, comércio de utensílios domésticos. Possui o Mercado da Farinha e o Mercado da Carne. Essa feira é permanente. A outra feira que ocorre uma vez por semana é a Feira da Sulanca e a Feira do Paraguai. No trabalho de campo observamos que o movimento da feira inicia-se já à noite de segunda-feira, em que eles montam barraca, muitos já começam a vender as suas mercadorias no chão ou aguardam nos seus veículos abarrotados de mercadorias. Os sulanqueiros são de Caruaru, Santa Cruz do Capibaribe e Toritama.

O corpo a corpo de feira representa toda a dinâmica desse mercado precarizado. Fomam-se trilhas para tentar caminhar naquela massa de gente, carrinhos, barracas, roupas coloridas. É um "bolo de gente", não se consegue ir para a frente, volta-se tentase outro caminho. Vê-se muitos barraqueiros nas primeira horas do dia dormindo nas bancas. Nesse entrave dos caminhos da feiras, vemos os carroceiros negociando as passagens, todo o tempo. Os sons se cruzam na feira com música, com conversas, com anúncios:

“- Bermudas para homem macho masculino.”

“- Brásmel cura todas as doenças.”

“- A muié tá com a rouba amassada, leve um cabide a ela...”

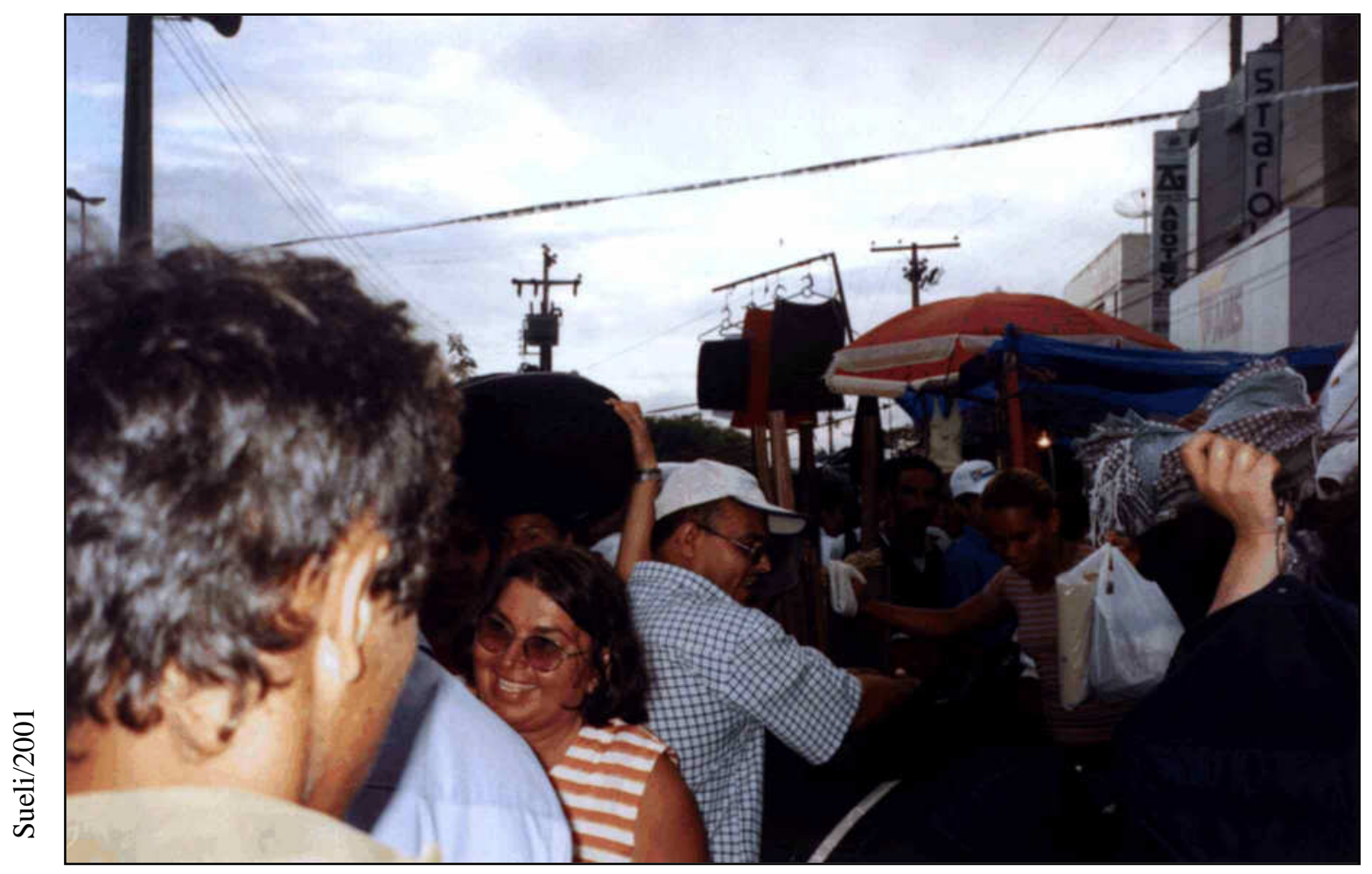

Foto 60: Feira da Sulanca Caruaru. 
Dezenas de milhares de pessoas são atraídas semanalmente de diversos pontos do Norte e Nordeste. Os sacoleiros vêm abastecer-se de mercadorias, principalmente, artigos da sulanca. A economia informal emprega milhares de pessoas e contribui para a situação do município. O comércio informal e formal de Caruaru movimentam em um dia o que normalmente movimentam no resto da semana. O comércio formal e os estabelecimentos em torno da feira dependem dela, principalmente da Feira da Sulanca.

\section{“Quem compra roupa, compra outras coisas também”. (Sebastião Monteiro)}

A sulanca é produzida em pequenas fábricas de "fundo de quintal", com um custo e mão de obra baratos, possibilitando a redução das vendas. Em conversas com Romildo da Secretaria de Finanças do Município. Ele nos revela que 50\% dos sulanqueiros não possuem CGC, não registram os funcionários. O salário de uma costureira está próximo de R \$ 225,00. Então o pessoal prefere trabalhar com as faccionistas, que cobram o serviço da costura por produção desobrigando as oficinas dos encargos trabalhistas. Essa seria uma forma de flexibilidade da mão de obra, que não passa apenas pelos grandes capitais.

A falta de infraestrutura leva a alguns problemas, como um incêndio em outubro de 2001, que destruiu algumas bancas, desalojando os barraqueiros. Sendo que essa preocupação já em 1998, tinha sido colocada pela associações e sindicatos:

“Um dos principais preocupações apontada pelas associações e sindicatos é a falta de policiamento, a falta de infra-estrutura, mais aproximação do Corpo de Bombeiros (instalação de hidrômetros e extintores), melhorar estacionamentos, um posto de saúde de pequenas emergências, sinalizações e um posto de atendimento para os turistas.” (SILVA, 1998: 14) 


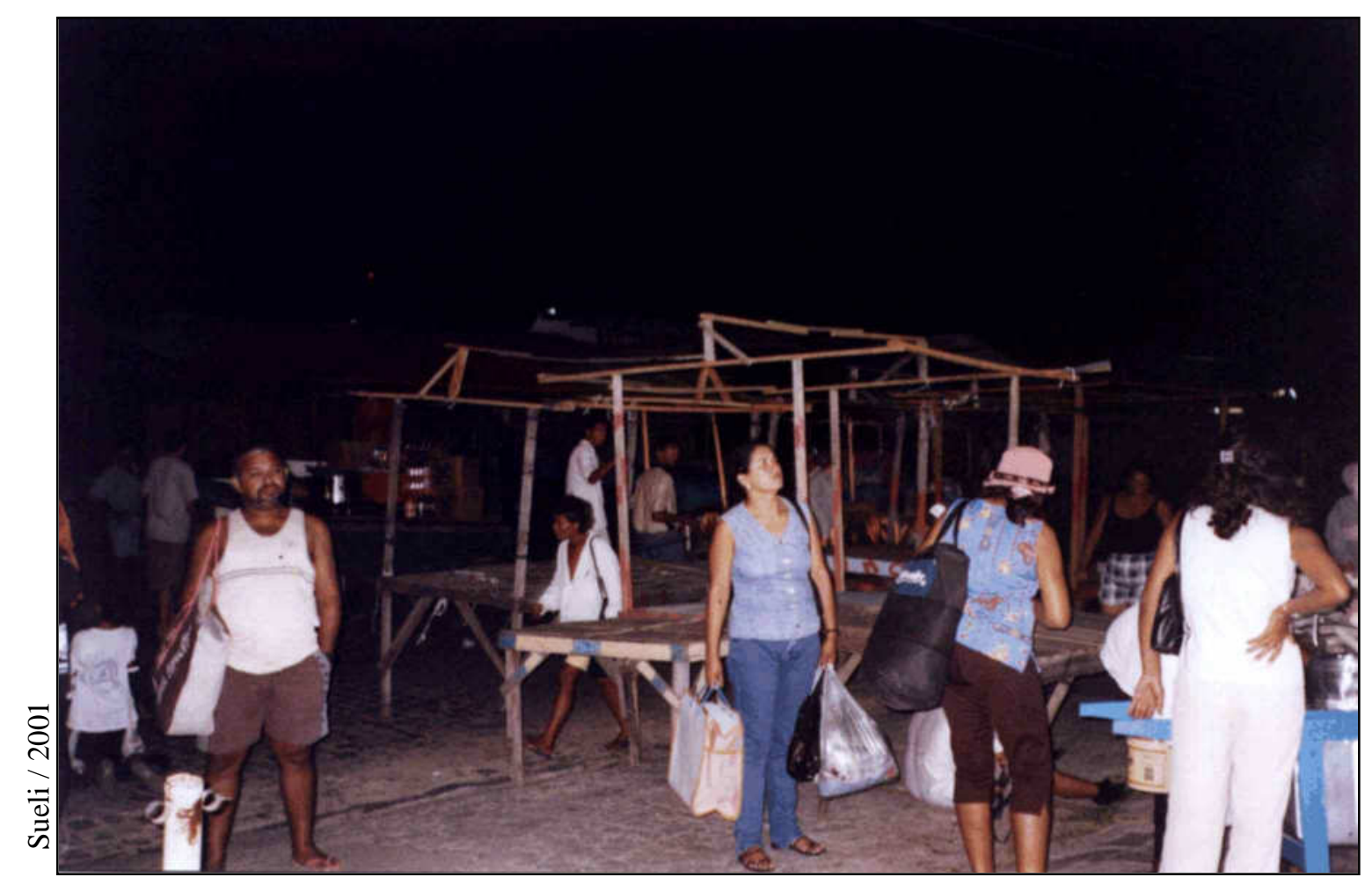

Foto 61: Início da Feira da Sulanca em Caruaru - PE.

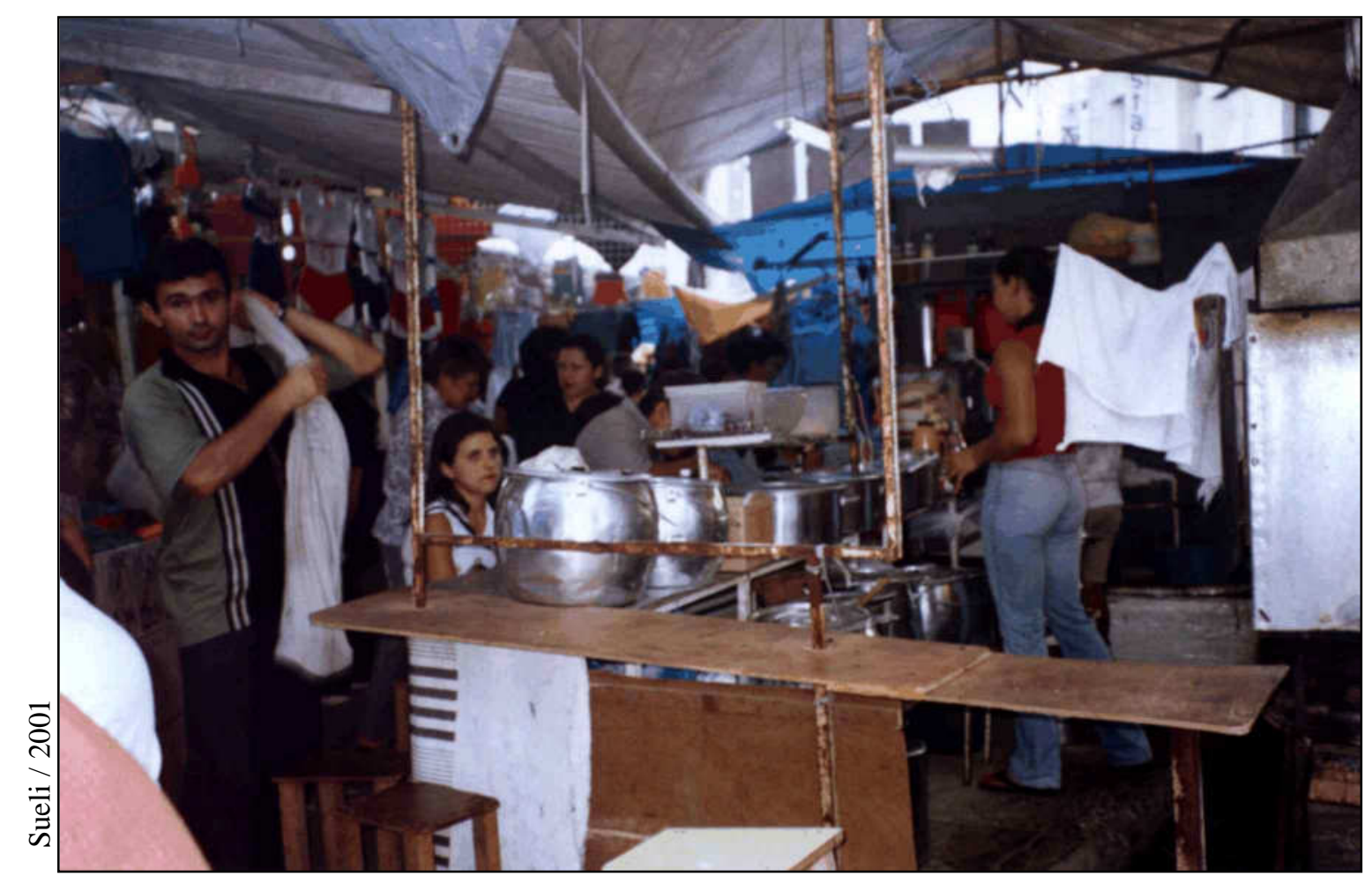

Foto 62: Barraca Restaurante da Feira da Sulanca de Caruaru -PE. 


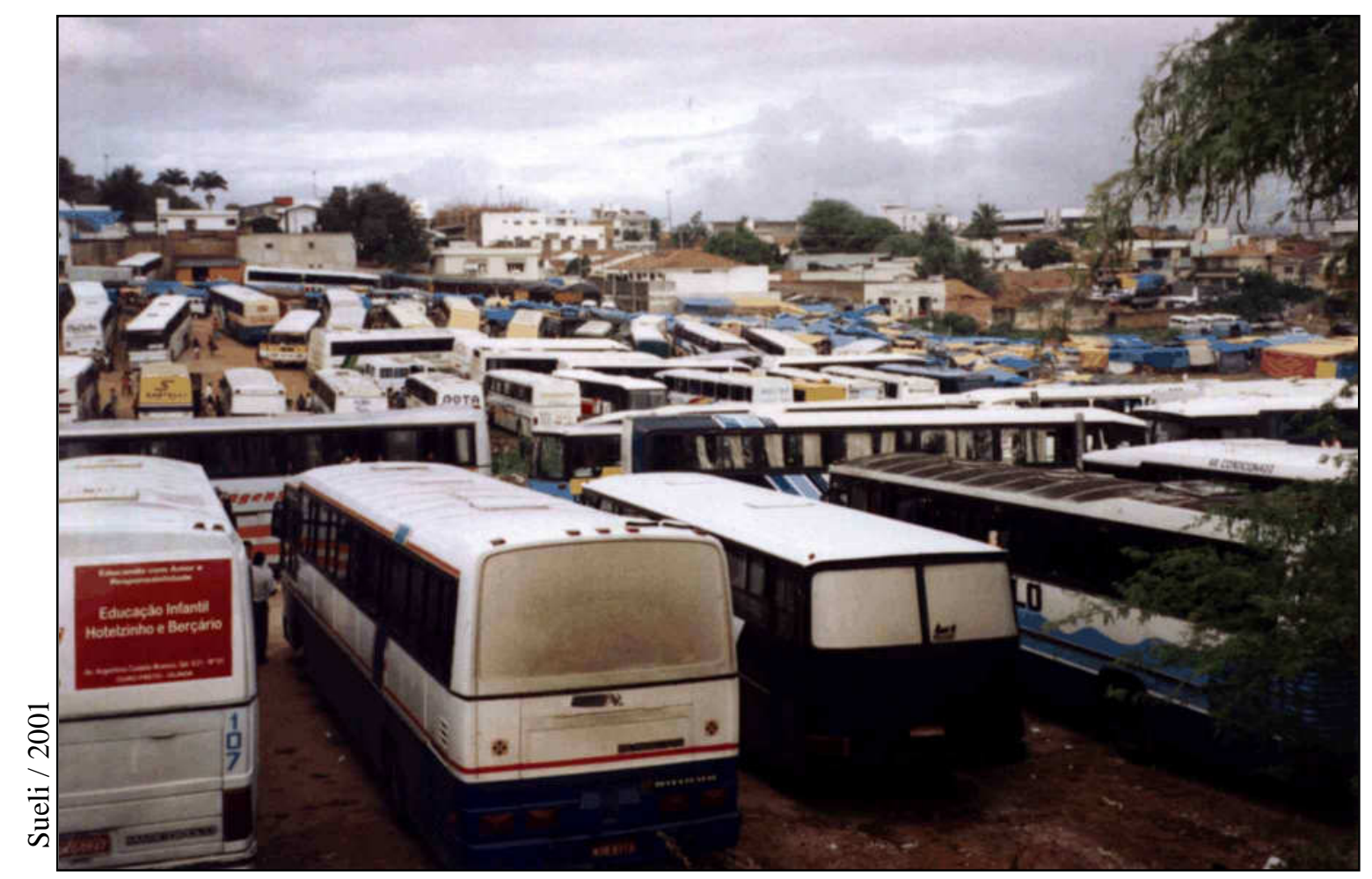

Foto 63: Estacionamento de ônibus dos sacoleiros em Caruaru.

Os motoristas dos ônibus de excursões falam da necessidade de hotéis 'baratos' para eles dormirem, pois passam a noite viajando e não conseguem dormir no ônibus, devido à grande circulação de seus passageiros para guardar as mercadorias. O presidente da associação dos sulanqueiros, Zé Carlos, sugere a organização de um lugar para guardar as mercadorias. No dia da feira escutamos o relato de pequenos furtos. Esses são denominados de "lanceiro", isto é, aqueles que se aproveitam do descuido do feirante para o roubo da mercadoria. Em 1998, os dados apontavam uma média de 15 pessoas por feira que eram aprendidas. Hoje o número deve dobrar.

“Hoje mesmo a mulher chegou chorando, levaram o dinheiro dela." (Sr. Carlos motorista de ônibus.)

Procuramos no trabalho de campo alguma ambulância, alguns dados sobre os atendimentos emergenciais, não encontramos. Não existe nenhum apoio aos sacoleiros, sulanqueiros nesse sentido. Encontramos um serviço de radio que tem uma enorme procura por pessoas perdidas na feira e também, objetos, como celular, documentos. A rádio tem uma procura de 100 a 150 pessoas por feira: 
"Toinha de Valdete de Santa Rosa da Boa Vista estamos aguardando no ônibus com a máxima urgência.” (Rádio)

Porém o alcance do som é insuficiente. A radio funciona em um antigo matadouro, chamada de casa rosada. Nessa casa ainda funciona o sindicato, cursos do SEBRAE e a Secretaria das Finanças e Desenvolvimento. Assim, facilita o recolhimento da taxa de $\mathrm{R} \$ 3,00$ por banca, por semana, realizado pela prefeitura. Esse local fica bem no centro da feira.

O fato de ocorrer um grande número de assaltos nas estradas aos ônibus de sacoleiros fez com que se definisse esse horário da Feira da Sulanca. Ela se inicia na noite de segunda-feira, ocorre pela madrugada e termina na terça-feira ao meio dia. Assim os sacoleiros viajam sempre quando o dia está claro, reduzindo o risco de serem assaltados.

O Jornal da Sulanca é um informativo mensal, publicado em Caruaru. Tem uma tiragem de 3000 exemplares, está no número 3 e é organizado pelo micro empresário Sebastião Silvestre Monteiro. Nele encontramos nos classificados anúncios de lojas e indústrias de confecções e afins desse ramo (aviamentos, tecidos, ...), emprego de costureira como o predominante. Seus artigos não se referem apenas à Feira da Sulanca de Caruaru, como também de Santa Cruz do Capibaribe e Totitama. Artigos que mostram o problema da pouca estrutura da feira para receber as sacoleiras, problemas na organização e todos os assuntos relacionados à sulanca, como: notinha que trata de uma viagem de um empresário das confecções que viajou para a Angola para negociar a exportação de confecções de Caruaru e cidades circunvizinhas. "Ele já exporta para Grécia, Portugal e Israel."

Esse foi uma elemento que confirmou o que alguns depoimentos, como o do presidente da Associação dos Sulanqueiros que complementa, citando os países Canadá, Bolívia que importam a sulanca. Esse seria um indicador do grau de alcance desse pólo de confecção e a sua ligação com outros pontos que ultrapassam o território nacional.

Sabendo que há um enorme consumo de tecidos nessa região, por que não desenvolveu-se a indústria têxtil nessa região? Sebastião Monteiro em sua entrevista fala do potencial industrial de Caruaru, deixando um recado aos empresários do Sul, das possibilidades de investimentos em Caruaru. Mas, em uma monografia e entrevista na 
CDL - Câmara de Dirigentes Lojistas de Caruaru, é atribuída a ausência de indústria em Caruaru devido à falta de abastecimento de água.

Outra feira significativa, mesmo tendo uma menor dimensão é a Feira de Toritama. No inicio ela se localizava no centro da cidade, depois ela foi para a beira da rodovia (entre Santa Cruz do Capibaribe e Caruaru). Recentemente, setembro de 2001, foi inaugurado o Parque das Feiras, que é de iniciativa privada. Esse Parque estava distante muitos metros da feira original e os sacoleiros continuaram se dirigindo para a área original da feira. Os proprietários temendo o fracasso do projeto do Parque cederam um terreno ao lado, para a prefeitura transferir a feira. Esse Parque tem 930 boxes e estão prevendo construir mais 500. O boxes estão quase todos alugados. Espaço coberto de alvenaria, como vemos na foto. Apresenta uma estrutura ao sacoleiro e a sua comodidade - banheiros, lanchonetes e restaurante. A maioria dessas bancas são ocupadas por oficinas de Toritama, os mais capitalizados, há também, poucos boxes de proprietários de Caruaru, Santa Cruz do Capibaribe e até Arcoverde e Vertente. A feira original ocorre de segunda-feira, enquanto o Parque das Feiras, também, funciona toda a semana, entretanto com uma boa parte box fechados. Mesmo assim, encontramos um número expressivo de boxes funcionando. Os boxes que estavam abertos eram das empresas maiores que possuem pessoas para manter aberto e ao mesmo tempo produzir em sua oficina.

Toritama se destaca especialmente pela confecção do Jeans. Os tecidos são de Fortaleza, São Paulo e um pouco importado, dependendo do valor do dólar. Os tecidos são de grandes tecelagens como a Vicunha, Cedro, Santa Rosa, Santista. Os retalhos não chegam a dez por cento, somente para a confecção de bolsas. São 2 mil oficinas "de fundo de quintal" - "os fabricos" acordo com a CDL de Toritama. O presidente da CDL, Sr. José de Lima Santos Filho, afirma que $80 \%$ da mão de obra de Toritama depende da lavanderia, estonagem e constura do jeans. São 60 lavanderias, 100 mil máquinas e mais, o setor do bordado. Isso tudo é terciarizado. O que predomina é a facção. Os grandes fabricos compram e tecido e terciarizam a produção. Essa produção atende desde norte de Minas ao Amazonas, chegando até São Paulo. 


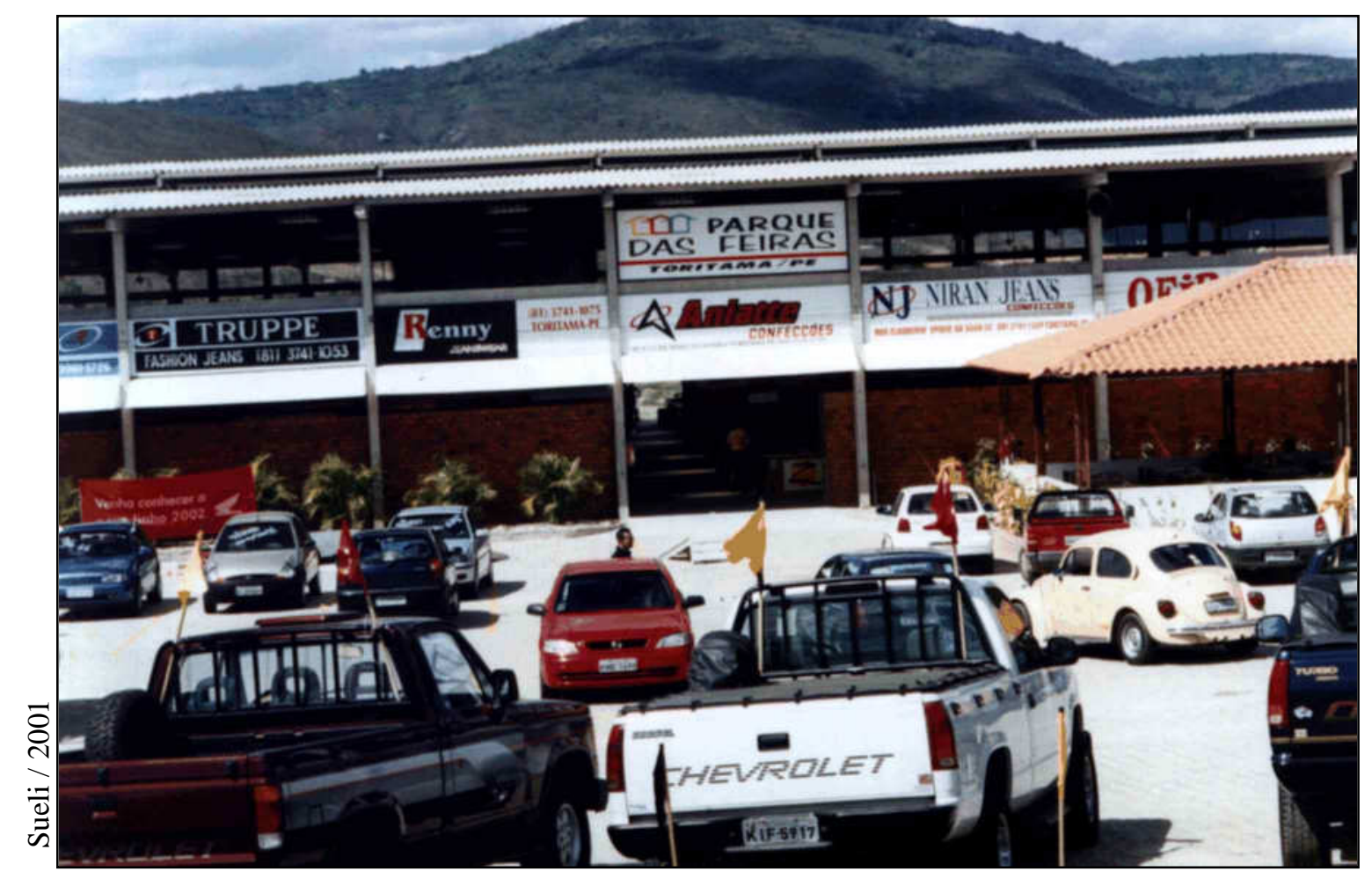

Foto 64: Parque das Feiras em Toritama.

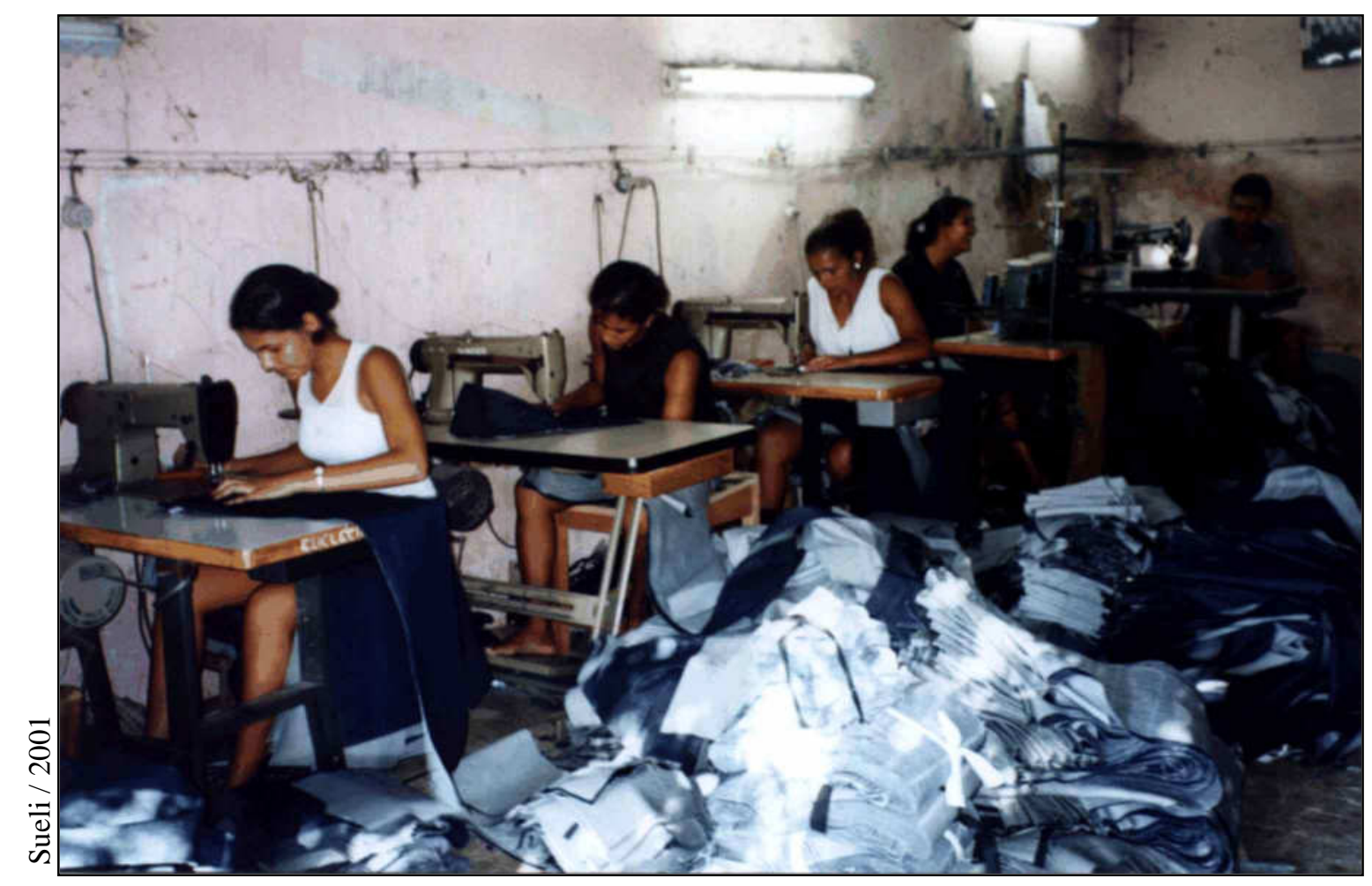

Foto 65: Oficina de Costura especializada em Jeans - Toritama. 
Considerando as péssimas condições geográficas para a agricultura e pecuária intensiva, a industrialização é o meio econômico que a cidade encontrou para se manter. Os moradores falam com orgulho que não existe desemprego na cidade. A indústria de confecção em Toritama, inicia-se bem depois de Santa Cruz do Capibaribe, mas com uma história semelhante, pois ela iniciou com retalhos e os resíduos que vinham de Santa Cruz do Capibaribe. Depois mais capitalizados se especializaram no jeans, enquanto Santa Cruz do Capibaribe na lycra e malha, e Caruaru se destaca nas confecções de malha.

Antes da indústria do jeans, havia a indústria de calçados, influenciado por Caruaru, mas essa última sofre um recuo. Em toda a região, ou melhor nessas três cidades há uma desindustrialização. As três cidades possuem diversas semelhanças nas suas características, como a grande presença de trabalho infantil na indústria e comércio da confecção, na produção, na comercialização. Mas há que se perceber as características da Feira da Sulanca de cada uma. Caruaru apresenta uma dimensão maior do que as outras duas, possui uma estrutura maior, mas também apresenta maiores problemas no espaço urbano. Santa Cruz do Capibaribe tem a feira mais antiga, com menos infraestrutura, mas que está em vias de sofrer grandes alterações, correndo o risco de perder ou de ganhar a competitividade das outras duas cidades. E por fim aparece a feira de Toritama, que apesar de ser a mais jovem, vem crescendo rapidamente, de uma forma um pouco menos desordenada que as duas últimas. Em Toritama, diferente das outras duas cidades, aparece o capital privado, querendo absorver o potencial econômico das Feiras da Sulanca, nem que para isso tenha que fazer acordos com o Estado. Enfim, vemos como essas cidades estão interligadas formando um nó da nossa rede de pessoas e mercadorias.

Outro aspecto comum a essas feiras é a sua clientela. Essa feiras sempre atenderam a população de menor poder aquisitivo, principalmente, das zonas rurais, conforme CAMPELLO (1983). É elevada a faixa da população que demanda essas confecções, principalmente o Norte e Nordeste. Essa população adquire seu vestuário nas feiras do interior, para onde converge essa produção a preços populares. Nos momentos de crise econômica, afeta o comércio de roupas, mas não da sulanca. Quanto pior a situação, maior é o número de consumidores de sulanca. 


\subsection{O circuito inferior: do comércio de retalhos à Feira da Sulanca}

Depois de desnudarmos os liames da circulação e produção do comércio de retalhos até chegar a confecção de baixa qualidade, faz-se necessário a reflexão sobre essa circulação, que explica o presente comércio. Ele está subjacente à produção e à circulação, pois nasce nos interstícios da indústria têxtil e de confecções. Possibilitará a reprodução ampliada do capital, quando amplia a circulação da mercadoria retalho, quando viabiliza a reprodução e a inclusão da população de baixa renda, formando consumidores de segunda categoria. Assim, esse comércio de retalhos compõem o processo de modernização e está subordinado ao capital.

HAESBAERT (1995) faz a seguinte afirmação:

“... as redes ilegais podem ser vistas ao mesmo tempo como produtos - à margem do sistema "legal”, impondo-se como forma de sobrevivência de grupos excluídos; ...”(183)

Assim, se considerar a atividade comercial fora do controle do Estado, ela é considerada como uma rede 'legal' e "ilegal', coexistindo no mesmos espaço, de forma hierárquica, como uma maneira de chamados "excluídos" buscarem a sua inclusão na sociedade. Alguns autores denominariam essa atividade como economia informal como CACCIAMALI (1983), JAKOBSEN (2000), PRANDI (1978), também é designada de economia subterrânea. Para melhor estudarmos essa questão, nos apoiaremos em SANTOS (1979) que trata a essa questão compondo os circuitos superior e inferior. O comércio de retalhos e a confecção da sulanca de Santa Cruz do Capibaribe compõem o circuito inferior interdependente da indústria de confecções e têxteis, que compõem o circuito superior. Para melhor entendermos, vejamos como SANTOS caracteriza o circuito inferior: a atividade, tanto no comércio como na indústria, trabalha com pequenos volumes de mercadoria, utiliza capitais reduzidos e, muitas vezes, dispensam uma organização burocrática. Tanto o trabalho familiar, como o trabalho autônomo são significativos nesta atividade comercial. O número de pessoas ocupadas é considerável.

"Esse circuito é o verdadeiro fornecedor de ocupação para a população pobre da cidade e os migrantes sem qualificação.” (p. 35)

E ainda: 
“... a acumulação de capital não constitui a primeira preocupação ou simplesmente não há essa preocupação. Trata-se, antes de tudo, de sobreviver e assegurar a vida cotidiana da família, bem como tomar parte, na medida do possível de certas formas de consumo particulares à vida moderna. (p. 35-36).

Não há quase custos fixos, há uma reutilização dos bens duráveis e não tem muito apoio do Estado. Esse circuito resulta da demanda, ou seja apoia-se no consumo. Enquanto o circuito superior tende a controlar a economia, o circuito inferior é subordinado a essa. Essas são algumas das características essenciais do circuito inferior. O fundamental é perceber que os dois circuitos estão interligados e possuem a mesma origem. Segundo SANTOS (1979), a revolução no domínio do consumo trouxe novas formas de consumo, vejamos como segue sua reflexão:

"A existência de uma massa de pessoas com salários muito baixos ou vivendo de atividades ocasionais, ao lado de uma minoria com rendas muito elevadas, cria na sociedade urbana uma divisão entre aqueles que podem ter acesso de maneira permanente aos bens e serviços oferecidos e aqueles que, tendo as mesmas necessidades, não têm condições de satisfazê-las. Isso cria ao mesmo tempo diferenças quantitativas e qualitativas no consumo. Essas diferenças são a causa e o efeito da existência, ou seja, da criação ou da manutenção, nessas cidades, de dois circuitos de produção, distribuição e consumo dos bens e serviços.” (p. 29)

$\mathrm{O}$ aumento da força de trabalho "acarreta a criação de atividades de pequenas dimensões”. Assim, a modernização gera dois circuitos que estão interligados - o superior e o inferior. SANTOS caracterizará esses dois circuitos, que fazem parte do mesmo sistema. Essa designação pretende superar o conceito de circuito moderno e tradicional, destacando o seu comportamento e organização e não a sua idade. $O$ circuito inferior, produto da modernização, está em processo de transformação e adaptação permanente, portanto chamá-lo de circuito tradicional seria um equívoco. $\mathrm{O}$ autor destaca a dependência do circuito inferior em relação ao superior, e nós acrescentaríamos a interdependência desses circuitos.

“A participação num consumo 'moderno' tem a tendência de atingir mais e mais indivíduos, mesmo se essa participação é parcial ou ocasional nas camadas favorecidas.” (p. 28) 
Em SANTOS (1979) encontramos a importância que o circuito inferior tem na vida urbana nos países subdesenvolvidos. Ele abriga a "população pobre migrante ou originária da cidade que só raramente pode consumir e trabalhar no circuito Moderno." (p. 158) O autor continua:

“... a economia urbana da pobreza, isto é, o circuito inferior, é explorada pelo outro setor através das condições do comércio... a provável função essencial do circuito inferior é 'difundir'. O modo Capitalista de Produção entre a população pobre através do 'consumo' e 'absorver' o para o circuito superior a 'poupança e a mais valia' das unidades familiares, por intermédio da máquina financeira, de produção e de consumo”. (SANTOS, 1979: 57)

LIMA (1987) discute a presença do pequeno comércio e afirma que a modernização impõem duas tendências: a formação de uma pequena burguesia, que são os pequenos comerciantes, e a do proletariado marginal, a clientela do pequeno comércio. Talvez, seja necessário fazer uma releitura dessas duas classificações das classes sociais urbanas, no entanto o viés da existência dessa parcela da população e de sua manutenção sob o capital é relevante. Outro aspecto dessa leitura é a caracterização do pequeno comércio:

“Caracterizando-se pelas pequenas dimensões de seu negócio; às vezes, reduzidíssimo espaço físico, capital, até mesmo redutível estoques de mínima qualidade; poucas pessoas ocupadas nos estabelecimentos, geralmente familiares; e pela jornada intensiva de trabalho, isso tudo lhe permite aumento da produção sem que haja necessidade de capital de giro.” (p. 123)

O autor continua a levantar vários aspetos do pequeno comércio, que correspondem ao comércio de retalhos e, também, da sulanca. Um exemplo é a quantidade de empregos que o comércio oferece, pela "multiplicidade" desses pequenos negócios, familiares ou individuais. Às vezes, o próprio proprietário assume, simultaneamente, a direção, o capital e o trabalho. Outra característica é a velocidade da circulação do dinheiro, ela é viabilizada, por um enorme número de intermediários, mas ao mesmo tempo, ocorre pouca acumulação. No nosso caso, há uma diversidade de acúmulos de capital; esse acúmulo é lento. Os retalheiros mais capitalizados estão exercendo essa atividade há mais de trinta anos, conseguindo pequenos bens, como uma casa, um carro e duas à três lojas, não mais que isso, um patrimônio modesto. Nessa 
circulação, geralmente o pagamento é à vista, pois os valores a serem pagos são baixos. "Seu lucro está diretamente ligado ao conjunto de suas vendas." (p. 123) O "segredo", ou melhor, o mecanismo desse micro acúmulo é "a visita em diferentes lugares onde compra bem mais em conta para vender com melhor margem de lucro.”, o que Milton Santos denomina de "comércio triangular".

Esse pequeno comércio, segundo LIMA (1987), tem o papel fundamental de abastecer o "proletariado".

"Corrobora com os hábitos de fragmentação de compra e venda, num eixo de permanência da distinção das classes sociais e na fixação da imagem urbana local.” (...) "Ele é, ao mesmo tempo, vítima e promotor de controle social. Vítima porque sempre dependente. Promotor porque reproduz o Modo de Produção Capitalista entre o consumidor, que, por sua fragmentação (na venda), representa o custo que barateia a força de trabalho dessa grande parcela da sociedade, cujo orçamento doméstico, habitualmente, é pensado em poucas dimensões. É, ao mesmo tempo, vítima e reprodutor dos mecanismos do capital.” (p. 124)

CACCIAMALI (1983) trará à luz, algumas ponderações acerca das proposições que destacam o papel do setor informal, como meio de atender necessidades da população mais pobre residente na periferia dos grandes centros urbanos. A autora afirma que os mais pobres não estão confinados, nem tem atitudes passivas de confinamento e não estão na produção para autoconsumo, ou visando suprir outros pobres. A autora continua,

“Muitos são assalariados regulares, (...) que integram o sistema de mercado, mal suprindo suas necessidades face ao baixo nível de renda que auferem. Engrossam, porém, o mercado interno consumindo variado número de produtos industriais distribuído tanto por firmas capitalistas como pelo Setor Informal." (CACCIAMALI, 1983: 43)

Atualmente, há confecções de Santa Cruz do Capibaribe, que abastecem a rede de lojas Marisa, loja especializada em confecções de baixo custo. E muitas confecções de Santa Cruz do Capibaribe estão vindo para São Paulo e Rio de Janeiro. A questão central está em entender como o comércio de retalhos e a sulanca transitam entre o setor formal e informal, ou melhor circuito inferior e superior. Para se conseguir um menor 
preço no setor formal, foram adquiridas matérias-primas, no setor informal. Esses setores estão entrelaçados, no nosso caso. Concordamos que o setor formal e informal convivem no mesmo espaço, como CACCIAMALLI afirma. O fato é que há alguns pontos de referência, para o consumo de vestuários à menores preços, como o Brás e as Feiras da Sulanca, onde encontramos uma predominância da população de menor renda. Isso não significa, que essa população não 'possa' consumir seus vestuários em shoppings centers, que tem outra clientela predominante. Sabe-se que em uma importante loja de jeans da rua Augusta, como a gerente da loja relatou, os oficce-boys compram uma única "calça de etiqueta" que será usada por dois ou três rapazes, pois esses fazem um rodízio nos fins de semana para usar esse vestuário.

Vemos que a mercadoria "barata", originada no circuito inferior, também é comercializada pelo grande capital, no circuito superior (Carrefour, Wall Mart, Marisa), além dos pontos de referência para esse consumo precarizado como o Brás e a Feira da Sulanca, esse processo evidencia mais a subordinação do circuito inferior ao circuito superior.

O comércio de retalhos, em nossa leitura, tem a função de abastecer o vestuário da população "excluída" do consumo e acesso à roupas de melhor qualidade, e inclusa nesse processo de reprodução ampliada do capital. Assim, tanto o comércio de retalhos, como o da sulanca, tem o papel de manter a desigualdade social, a sustentabilidade da pobreza, a de manter a "impressão do baixo custo no consumo; seria o "elo controlador" entre o Capital e o "proletariado" (LIMA, 1987), ou melhor, o comércio de retalhos seria um instrumento do processo de "inclusão".

O conceito de exclusão e inclusão foi explicitado na reflexões que MARTINS (1998) realizou no Simpósio da Pastoral do Imigrante, esse debate nos conduziu a uma releitura do denominado proletariado marginal, que LIMA (1987) utiliza-se para distinguir a clientela ou consumidor de "segunda categoria".

“Na sociedade capitalista, a rigor, não pode haver exclusão; não pode existir sociedade capitalista baseada na exclusão; não pode existir sociedade capitalista baseada na exclusão. Toda dinâmica dessa sociedade se baseia em processos de exclusão para incluir”. (MARTINS, 1998: 19)

O autor continua essa reflexão, que será o apoio teórico para o entendimento do nosso objeto. 
"Há duas portas para se entrar nessa sociedade. Uma é a porta mais geral da transformação de todos em produtores e vendedores de mercadorias. Tudo tende a ser reduzido à mercadoria. Essa redução de tudo a produtores $e$ consumidores de mercadoria significa que todos, para se integrarem na sociedade capitalista, devem ser transformados em trabalhadores ou, então, em compradores de força de trabalho. Em segundo lugar devem ser todos transformados em consumidores dos produtos produzidos por essa mesma sociedade”. (MARTINS, 1998: 20)

Para entendermos melhor seu pensamento, vejamos:

"Nesta sociedade, hão há como sobreviver sem se tornar consumidor, ainda que consumidor de menor riqueza do que aquela em cuja produção se esteve envolvido. Portanto, há um componente ilógico na noção de exclusão." (MARTINS, 1998: 20)

Seguindo esse pensamento, identificamos o migrante comerciante de retalhos, inserido e buscando cada vez mais a sua inserção. Assim, ele aproveitará o resíduo das confecções paulistas e criará uma mercadoria de segunda categoria que possibilita a inclusão de seus conterrâneos como consumidores de menor poder aquisitivo, tanto quanto ele próprio, os consumidores de Santa Cruz do Capibaribe e outros pontos da rede.

Outra discussão que o estudo permite é entender essa procura do migrante de fazer parte da sociedade consumidora, para isso ele se instrumentalizará dessa atividade, que é uma alternativa de trabalho. Os migrantes que pesquisamos criaram e se inseriram na atividade do comércio de retalhos buscando a sua estratégia de reinclusão, mesmo à margem de um mercado, sendo então um "consumidor marginal, que é essencial à reprodução do sistema econômico.” (MARTINS, 1998: 23). 


\section{NO ESPAÇO DAS REDES SOCIAIS: O COMÉRCIO DE RETALHOS}

\subsection{Quem são os retalheiros?}

A grande parcela das pessoas que trabalha nessa atividade é constituída de migrantes nordestinos, podendo dividi-los pelos locais de origem: o primeiro grupo está ligado à família do Sr. Otávio, apelidado de Dudu, da cidade Ibirajuba, Pernambuco, que tem uma dimensão maior que o segundo grupo, o da família do Sr. Moacir, de Iguatu, Ceará; o terceiro grupo, que tem outra característica, é formado por migrantes de Santa Cruz do Capibaribe, Pernambuco e cidades vizinhas. Este último grupo de migrantes surge seguindo o fluxo desse comércio, pois todos os dias saem caminhões, levando toneladas de resíduos e retalhos para Santa Cruz do Capibaribe, que no retorno, também serviam de transporte para o migrante, conforme afirma o depoimento de um comerciante: "cada caminhão de tecido trazia 5 ou 6 ".

Assim, a formação desse comércio está também mediada por redes sociais de parentesco ou apadrinhamento, entrelaçadas por redes econômicas e redes territoriais, no caso, as famílias de Iguatu e Ibirajuba. Para entendermos o comércio de retalhos como uma das formas de inserção de migrantes em São Paulo, encontramos essas redes, que nos fornecem elementos para analisar o seu papel como apoio ao migrante que acaba de chegar e, simultaneamente, contribui para a ampliação desse comércio. Os primeiros migrantes nordestinos que iniciaram o comércio de retalhos chegaram em São Paulo por volta da década de 1960. Assim, como discutimos nos capítulos anteriores, forma-se uma grande rede de pessoas e mercadorias, que tem como ponto de apoio ou nó, o Brás. Esse bairro será o nó que interligará essa rede.

O conceito de rede aparece como uma nova configuração espacial, característica da modernidade. A reflexão de HAESBAERT foi importante para o entendimento das mudanças no Brás: o que era no passado um bairro, território contínuo e coeso, hoje tornou-se um nó da rede, ou um território, onde se localiza essa atividade comercial, suporte em que a rede pode se apoiar. A modernidade trouxe a racionalidade do espaço, transformando-o em vértices, arestas, linhas, nós e aglomerados. A rede de migrantes e a rede do comércio de retalhos são redes que se superpõem e têm o seu ordenamento, 
formam uma malha de homens e mercadorias ou uma malha de múltiplos territórios. HAESBAERT cita DEMATTEIS (1992) que caracteriza a cidade como:

“... 'um conjunto de nós pertencentes a diferentes redes', 'um conjunto de sujeitos fisicamente coexistentes, mas que pertencem a redes de organização diferentes e cujos interesses podem divergir à escala local. (...) Assim o espaço físico de cada cidade seria a sede de vários 'nós' pertencendo a sistemas diferentes, cada um com forma de enraizamento local (relações 'verticais') distintas.” (DEMATTEIS apud HAESBAERT, 1994: 182).

\subsection{As relações "familiares" de trabalho}

Nas relações de trabalho, que identificamos nas unidades de comercialização, o que predomina é a mão de obra familiar. Inicialmente, muitos formaram uma "sociedade", em geral, constituído por parentes, e depois, cada sócio obteve a sua própria loja. O ganho que a família tem é voltado para os gastos com aluguel, roupa, alimentação, muitas vezes, inexistindo a remuneração para os parentes pertencentes à unidade familiar. O pai é geralmente o "chefe" da unidade, responsabilizando-se em ajudar os filhos a terem o seu próprio negócio. Essa organização interna aparece de forma evidente nas entrevistas de nossa pesquisa, como veremos abaixo:

“Pago não. Eu ajeito eles por aqui. É coisa que se sabe. Essa casa mesmo é deles tudo. Porque eu comprei pra eles trabalhar mais eu. Eu mesmo arrumo um cantinho. Cheguei na Almirante Barroso, ali quando eu comprei essa casa, deixei lá uma filha mais velha..." (Sr. Zagaia $)^{2}$

"Nós tamo com vontade de largar tudo, ele não anda muito bom, porque ele já é aposentado. No ano que vem, quem vai ficar aqui vai ser minha filha com meu genro." (D. Miriam)

"Quando precisa, entendeu, divide pra família inteira (...)." (Teresa) 
Essa organização interna e o trabalho familiar foi discutida por WOORTMANN, Klaas A. W. em A Família Trabalhadora(1984).

Poucos se identificam como funcionários, quando o indivíduo se reconhece como tal é porque mantém com o proprietário uma relação de parentesco mais distante tais como, sobrinhos, primos, tios. Alguns depoentes destacam a idéia da "ajuda", como no caso de Dona Miriam:

"Parente minha, ela ajuda". "Ela é registrada, a gente não gosta de fazer nada enrolado". (D. Miriam)

A idéia de auxiliar o parente ou conterrâneo está muito presente nesses retalheiros. A solidariedade nas redes aparece nos depoimentos, apontando para a precariedade na área de origem e a possibilidade de ajuda por meio dessa atividade. Outro aspecto que a rede de relações traz é o aumento progressivo de pessoas no ramo do comércio de retalhos e, portanto, o aumento de unidades comerciais. Então, havia um problema a ser investigado, que era entender a contradição que esse comércio apresentava - quanto maior o número de unidades, maior a concorrência no mercado -, entretanto, não havia a preocupação desse comerciante-migrante com a competição, e sim, com estímulo de inserir o conterrâneo nessa atividade. Como explicar a coexistência da competição nesse mercado com o exercício da solidariedade?

A solidariedade se justifica entre os migrantes que vieram de uma região com dificuldades de emprego e de precárias condições de vida, que também se encontram em São Paulo, sem meios de sobrevivência. Soma-se ao fato da presença do maior número de lojas do mesmo ramo no mesmo espaço, especializando-o de forma a atrair o maior número de compradores, facilita a circulação dessa mercadoria. Estabelece-se nesse local, uma referência para o comprador, que é atraído por uma mercadoria determinada que, no caso, é o retalho, ampliando-se então, o número de depósitos e lojas concentradas nas ruas do Brás.. Esses elementos permitem um maior entendimento da coexistência dessas duas condições: solidariedade e concorrência. Vejamos alguns depoimentos dos comerciantes:

"São grande, tem muito lugar para trabalhar. Acho que isso é egoísmo, quem quer só pra si; se que adiantava ficar sozinho..." (D. Mira) 
"A princípio eu pensava que podia prejudicar, quando chegava um outro concorrente. Mas agora não. Dizem segundo os comerciantes mais antigos, que até valoriza, tem mais procura, tá assim, todos têm direito a um raio de sol." (D. Marta)

"Não, pra mim tá melhor, que nem aqui as freguesas que eu tenho, o de outras, se aí do lado, tem uma loja também, se lá não tem uma coisa, aqui se tiver eles já vêm trocar, ou se aqui não tem, ele, vão pra lá. Pra mim não faz diferença, se tem loja ou não tem." (Teresa)

"É não, é não. Eu quero que tudo mundo viva, né mesmo, Deus do céu, só vendo lá, o Sr. vendo caso eles querem brigar, eu ajeito. Às vezes só tem um quarto pros dois. Ele faz uma lista no meio pra cá, é um pra lá, é outro. Tudo filho de Deus, né? (Sr. Zagaia)

Um depoente paulista que trabalha junto aos pernambucanos e foi inserido pela amizade desses, em São Paulo.

"Isso é besteira. Veja bem, o nordestino quando vem do Norte para cá, o maior objetivo dele é tirar o pessoal da desgraça que tá lá... Mas o pessoal que vem do Nordeste, do agreste, eles passam é fome lá, então quando o cara vem para cá... tem um rapazinho que chegou esses dias. É de Itabira, lá no Nordeste. Ele tá com 20 anos e nunca viu uma nota de 50... Então o cara chega aqui, começa a ver dinheiro. Começa a faturar 10, 15, 30..., e fica nisso. Então ele começa a ver dinheiro demais, que depressa ele chama o pessoal, que tá por lá passando fome, e começa a vir. Aqui nessa rua João Boemer, se vê uns buraquinhos com 10, 15 pessoas lá dentro trabalhando, parece um ninho de rato, todo mundo juntando lá dentro, homem por cima dos trapos, por cima dos resíduos. Então não é uma questão concorrência, realmente, é uma questão de sobrevivência. Então se eu tenho meu irmão que mora lá na casa do chapéu e eu sei que ele tá passando uma situação difícil,- 'Vem prá cá, outro passando... vem prá cá, que a gente se vira'. O cara nunca traz pensando que vai ser mais um concorrente, mas pensando que vai ser mais um que tá deixando de passar fome. É isso."(XiqueXique)

A questão da concorrência para o conterrâneo e parente é descartada, mas observando o dia a dia do correntista, vemos que ela aparece claramente, quando ocorre 
o chamado "furo", isto é, o correntista sabe de uma loja que venderá retalhos, a um bom preço, e outro correntista consegue essa informação. O segundo correntista, passa na frente e acaba por fechar negócio. Isso transparece até quando aplicamos a entrevista na qual eles relataram ter medo de espião, “que tinha muito disso lá”, outros diziam:

"Existe o furo, eu nunca fiz isso, mas teve muito grandão que já passou na polícia por causa disso. (...) O furo, é por exemplo, eu tenho um negócio por telefone, você sabe, corre logo na minha frente pra fechar negócio” (Francisco)

“... e outra que a concorrência entre os corretores é também ferrada, também, eles briga - Ah! Minha boca, se furô minha boca, num sei que em muito disso e depois eles já tão há mais tempo aqui.” (Zé)

“Já passa a perna, passa primeiro. Às vezes é avisado antes de você ir na loja ou pessoa de lado, às vezes ganha troco por fora, já pra te avisar antes, entendeu? É assim, quem tá nesse ramo faz tempo tem certas vantagens, já é mais conhecido”. (D. Marta)

\subsection{No espaço das redes}

Para entendermos a presença do comércio de retalhos organizado pelos migrantes, fomos buscar em PÓVOA-NETO uma síntese que pode explicar com clareza como essas redes sociais atuam no processo migratório:

"A presença destas redes de contato, cristalizadas ao longo de décadas de migrações, contribui para explicar a intensidade dos deslocamentos populacionais mesmo numa situação social em que os diferenciais de renda e de condição de vida se tornam pouco perceptiveis. Tais redes se tornam forças sociais vivas, a estabelecer 'pontes' entre lugares e a permitir o fluxo de informações e pessoas que fizeram da mobilidade geográfica a sua principal estratégia de sobrevivência.” (PÓVOA-NETO: 1998, 22). 
Os primeiros nordestinos descobrem essa nova possibilidade de inserção. Esse comércio, inicialmente era uma estratégia de sobrevivência, mas depois, com a circulação rápida dessa mercadoria e um acúmulo rápido de capital, tornou-se uma forma de ascensão social, atraindo parentes e amigos conterrâneos para trabalhar no comércio de retalhos.

Os retalheiros apresentavam pessoas, citavam amigos e parentes nos seus depoimentos. Os primeiros retalheiros inseriram seus irmãos, filhos, cunhados, primos etc. Observamos a circulação de pessoas na atividade comercial a todo instante. As lojas apresentam um misto de formalidade e informalidade e são um ponto de apoio para os iniciantes. Os antigos retalheiros já estão estabelecidos e trabalham mais com os retalhos, e até mesmo com peças inteiras; esses, com suas lojas, abrem espaços para os recém- iniciados que trabalham com os resíduos. Há uma troca: o antigo retalheiro cede, para o recém-chegado, o espaço da loja, informações, contatos, ensinando-o, também, a trabalhar e, em troca, recebe uma porcentagem de suas vendas de seu trabalho. De acordo com RAMELLA, os migrantes são atores racionais que perseguem objetivos e mobilizam para tais fins os recursos que têm à sua disposição.

“Estos han sido considerados, a menudo, como recursos relacionais, es decir aquellas relaciones personales que sirven para conseguir información, elegir el destino, insertarse en el mercado de trabajo la sociedad receptora, etc..." (RAMELLA, 1995: 9).

Observamos que a rede social é um mecanismo de mobilização, pois o antigo retalheiro aciona o novo, este, por sua vez, aciona o antigo retalheiro para se estabelecer. Esses últimos são mobilizados pelo sonho de ascensão social e de ter a sua própria loja. É uma cadeia hierárquica que organiza essa atividade comercial. O autor acima citado chama a atenção para o fato de que, há muito tempo, a noção de cadeia migratória forma parte da bagagem dos instrumentos metodológicos dos estudos históricos da migração, o que nos remete DURHAM (1973), na sua obra $A$ caminho da cidade, ou então em WOORTMANN (1984) que traz à luz a unidade familiar e o trabalho, e ainda BAPTISTA (1997) que utiliza esse conceito da seguinte maneira:

“... são vistas como relações simbólicas de afeto, parentesco, solidariedade, violência. Servem de apoio para o movimento da migração, assim como para o assentamento, engajamento e apropriação do espaço urbano.” (p. 11) 
Essas redes criam novas formas de sociabilização que, para a autora, podem vir a ser canal de mobilização e enfrentamento das questões sociais emergentes. BAPTISTA vê as redes sociais de solidariedade como tática de resistência e sobrevivência. Em nossa pesquisa, veremos outra vertente do enfoque das redes que mobilizam, também, para a exploração da mão de obra e para o acúmulo de capital individual, além de um recurso que o próprio capital mobiliza para a sua reprodução.

Os antigos retalheiros que têm um movimento maior em suas lojas contratam como funcionários, migrantes nordestinos com pouco tempo em São Paulo. Em outras unidades, encontramos uma relação familiar para o trabalho na loja. Os depoimentos mostram que algumas lojas eram usadas como moradias de famílias inteiras. Esses migrantes têm o trabalho de separar as peças de retalhos, pelas características que essas apresentam (tamanho, cor, etc.). O trabalho é contínuo e não tem hora para ser realizado, mesmo fechando as portas do horário comercial, eles passam a noite separando os retalhos, sendo que muitas vezes, esse tipo de trabalho não é regulamentado. A relação entre os conterrâneos apresenta uma duplicidade, pois ao mesmo tempo em que aparece a solidariedade e a inserção de parentes e amigos nesse mercado, abre-se a possibilidade aos migrantes antigos que estão no topo, de um maior acúmulo de capital, com a mais-valia gerada pelo novos migrantes. É a lógica da acumulação capitalista.

A pesquisa de BAPTISTA faz um estudo das redes sociais de nordestinos na favela de Paraisópolis em São Paulo. Vejamos a sua leitura sobre as redes sociais:

"A matriz dessas relações são pessoas enredadas por origem, parentesco, dificuldades, amizade, afetividade, desafios, compadrio. Explicitam-se aspectos que mostram o funcionamento e efetividade, das redes de atração $e$ inserção no urbano e como elas reproduzem e alimentam o fluxo migratório, assim como a solidariedade entre os chegados, atuação com os que chegam, como e quem atua junto aos migrantes. As redes sociais apresentam-se, então como táticas de produção e reprodução, econômica e cultural que unificam a vida anterior e atual..." (BAPTISTA, 1998: 24)

Para a autora, os migrantes são atores interconectados, que possuem uma identidade comum (cultura, classe social, temporalidades). Eles se apóiam no passado (área de origem), no presente (o convívio) e no futuro (seus sonhos).Ocupam os 
mesmos espaços e se socializam. As redes sociais são elos fortes que manifestam se de diferentes formas: solidárias, conflituosas, visíveis, latentes e estratégicas.

No Universo de análise do mundo dos retalhos esses aspectos evidenciam-se dialeticamente relacionados à competição no centro urbano permeado pelas relações capitalistas de produção.

\subsection{Os limites da rede: entre a solidariedade e a concorrência}

A pesquisa sobre o comércio de retalhos pôde constatar nos depoimentos, conflitos que ocorrem nas relações de negociações entre os migrantes retalheiros. Observamos que, em alguns aspectos, a conterraneidade perde o seu significado e a rede de solidariedade ocupa uma posição secundária. Um exemplo é a exigência de pagamento à vista pela mercadoria, por seu pequeno valor, mas também uma forma de mostrar as relações de confiança entre esses nordestinos. A confiança somente aparece entre os antigos conhecidos de um mesmo local de origem e seus parentes; fora isso, a negociação ocorre com cautela; não é a origem que define a confiança, mas o tempo de amizade entre as partes, mesmo esta, pode ser abalada:

"Z. B. tu me vende 30 e 60? Seu D. ali - 'Que é isso? Eu te conheço rapaz!' Naquele tempo a gente mexia com gado. Ele me conhecia também. Aí, ele me vendeu o depósito, aí umas firmas todinha que nem eu pego hoje. Aí acabou-se tempo ruim.” (Zé)

"Já me roubaram muito aqui nesse São Paulo, é um lugar... Cheque sem fundo, ladrão aqui. Chegou um aqui da minha terra, que morava aqui há muito tempo. Comprou umas dúzias e me enganou... E outro ladrão aqui, me roubou aqui, naquela rua ali. Comprava um retalhozinho a ele - 'Zeca tem um retalhozinho? É o infeliz, dono de loja, ainda, chegou aqui né, ladrão, que nem nosso Senhor se livrou da falsidade, como diz o povo... Eu conhecia o homem há muito tempo, eu pegava resíduo na loja dele, um ladrão, conheço o nome daquela peste”. (Sr. Zeca).

MIGUEZ (1995) avalia os estudos das redes sociais como uma recuperação valiosa porque é capaz de "mostrar as brechas e espaços abertos pelas completas incoerências de todo o sistema". Essas "incoerências", ao denominarmos de 
contradições, aparecem nas relações dos retalheiros que, ao mesmo tempo, são o ponto de apoio de outros migrantes que se inserem na atividade, de uma forma solidária. Essa relação também é uma forma de acúmulo da mais valia produzido pelo conterrâneo. Assim, há os dois viéses dessa condição que, em alguns momentos, são rompidos por conflitos que, muitas vezes, não foram explicitados nessa trama de relações. Muitas pesquisas tratam essas redes com estigmas de família modelo, ou o conterrâneo solidário, esquecendo as relações conflituosas em que a conterraneidade nem sempre é sinônimo de solidariedade. Os vínculos familiares e de amizade devem ser vistos como uma construção social.

Esses vínculos que servem de apoio ao migrante foram muito abordados nos estudos de MIGUEZ, recebendo a denominação de "rede de chegada". Outros estudos irão denominar as atividades, nas quais os migrantes se inserem via esse elo de relações, como mobilidade ocupacional ou especialização ocupacional ética. Muitos desses estudos concluíram que essas redes definem universos ocupacionais, favoráveis à mobilidade.

“Por tanto, son las relaciones personales, en tanto canales de transmisión, las que determinan quién tomará cúal trabajo.” (RAMELLA, 1995: 19)

Outra questão muito discutida nesses estudos é a difusão das informações. É importante destacar a informação como estratégica nessa atividade comercial: os melhores preços, as pessoas para comercializar, os números de telefones das confecções, enfim, até a formação básica de como se portar nesse mercado, como vemos no depoimento abaixo.

"Foi seu D. que ensinou como se chega nas lojas prá falar com... e hoje é turco, coreano. Eu chego nas lojas deles, palavra de Deus, venda de retalho, aí vou no bolso, acabou-se' - 'Não tenho talão de cheque' - 'Vai-se embora, depois do almoço venha'. Caminhonete cheia de tecido, era de tecido, hoje não vale nada, era tecido, eles mandavam embora. Tem um turco, judeu. Sr. Isaac, aqui eu compro no tempo que tava cortando plush, moleton, que é mercadoria mais cara. Eu compro a ele 200, 300, 400 quilo que é 20, 30 e 40 mil cruzado, acontece do mesmo jeito que não ter talão de cheque. Ele me manda embora, palavra de Deus. Do jeito que sou conhecido, pra senhor vê. Tem um ramo, é turco também, lá em Guarulhos, quando cheguei lá, ele disse - 'Olha, vou dizer logo para você, cheque eu não quero, só quero dinheiro'- 'tá 
tudo bem'. A mercadoria eu não sabia, eu deixo comprada. Se der pra mim amanhã eu venho ver, mesmo assim eu fiz, a mercadoria deu retalho que taí deu, eu comprei. No outro dia cheguei aqui, peguei o dinheiro, levei e paguei. Hoje sabe o que ele faz. comigo? Eu vou lá, a firma tá cheia de caminhão. EIe manda trazer aqui e manda carro embora. E manda trazê aqui. Cê acredita como no outro dia eu vou pagar a ele. Deus tá no céu." (Zé)

\subsection{Redes: difusão de informações}

Porém, essas redes não são somente difusoras de informação. Existem outras formas delas operarem, não só na circulação das indicações, mas também no apoio "logístico", espaço físico da loja, material básico (telefone, balança) e até moradia, quando necessário.

Aquela relação pessoal que serve para conseguir a informação, eleger o destino, inserir-se no mercado de trabalho da sociedade, será chamado por RAMELLA de recurso relacional que, no nosso estudo, foram basicamente os precursores dessa atividade que inseriu muitos migrantes. Vejamos o que o autor acima afirma:

“... la información no es um bien 'libre’ en el mercado, disponible para todos en la na misma medida: los individuos tienen una información limitada, dependiente de sus redes de relaciones.” (RAMELLA, 1995: 19).

O desempenho do retalheiro dependerá, além do seu trabalho, das oportunidades e do acesso a um bom lote de mercadoria, muitas vezes indicada pelo seu "padrinho" retalheiro.

Entretanto, identificar essas famílias somente, não satisfaz o entendimento do processo de formação desse comércio. As redes sociais são mediações que estão presentes nessa atividade, devem ser estudadas, para o entendimento de como ela se amplia e se reproduz para o capital. RAMELLA destaca o entendimento do impacto que essas relações sociais provocam na economia. Entendemos que as redes sociais perpassam as relações econômicas, servindo de apoio para o seu desenvolvimento.

Segundo RAMELLA, houve uma mudança nos paradigmas: a emigração deixou de ser uma ação de desesperados, compelidos, vítimas de suma situação econômica 
catastrófica e se transformou em “... una elección realizada por individuos movilizados por estrategias de superación social.”. (RAMELLA, 1995: 11)

Em um depoimento tomado entre os nordestinos, percebemos a expressão "foi encostando" para relatar a entrada dos parentes no ramo do comércio. Assumindo assim, a idéia de ponto de apoio nesse processo de desenvolvimento do comércio. Outro aspecto fundamental na análise da rede é o seu papel para a inclusão do migrante nesse sistema. Os migrantes que pesquisamos criaram e se inseriram na atividade do comércio de retalhos buscando a sua estratégia de inclusão, mesmo sendo um "consumidor marginal, que é essencial à reprodução do sistema econômico.” (MARTINS, 1998: 23)

"O que é um trabalhador à procura de trabalho? É a pessoa que está procurando a reinclusão na sociedade através do meio mais seguro para que o expropriado e desenraizado tenha uma inserção estável nas relações sociais”. (MARTINS, 1998: 21)

Enfim, o comércio de retalhos amplia-se à medida em que as redes sociais atuam, servindo de apoio, principalmente, com as informações próprias desse mercado. Então, para o grupo de migrantes que estudamos, ela tem servido para definir os seus itinerários e a sua inserção no urbano e no mercado de trabalho. Desse modo, a ampliação do comércio de retalhos redefine a configuração espacial, na qual a rede de mercadorias e de pessoas se confundem. Podemos perceber como o processo econômico incorpora as redes sociais para a reprodução e ampliação do capital. 


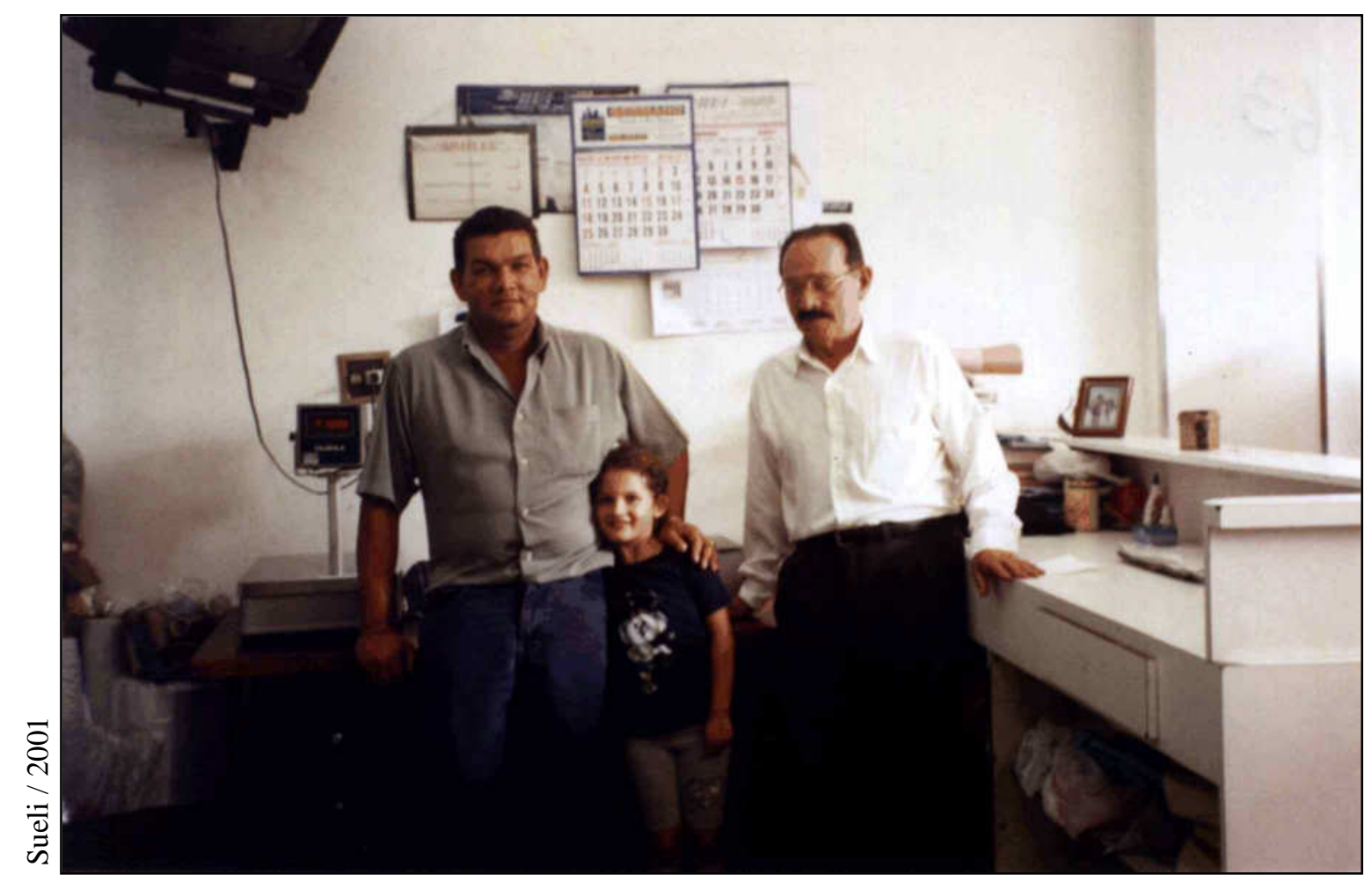

Foto 66: Sr Dudu, de Ibirajuba -PE, seu filho e sua neta.

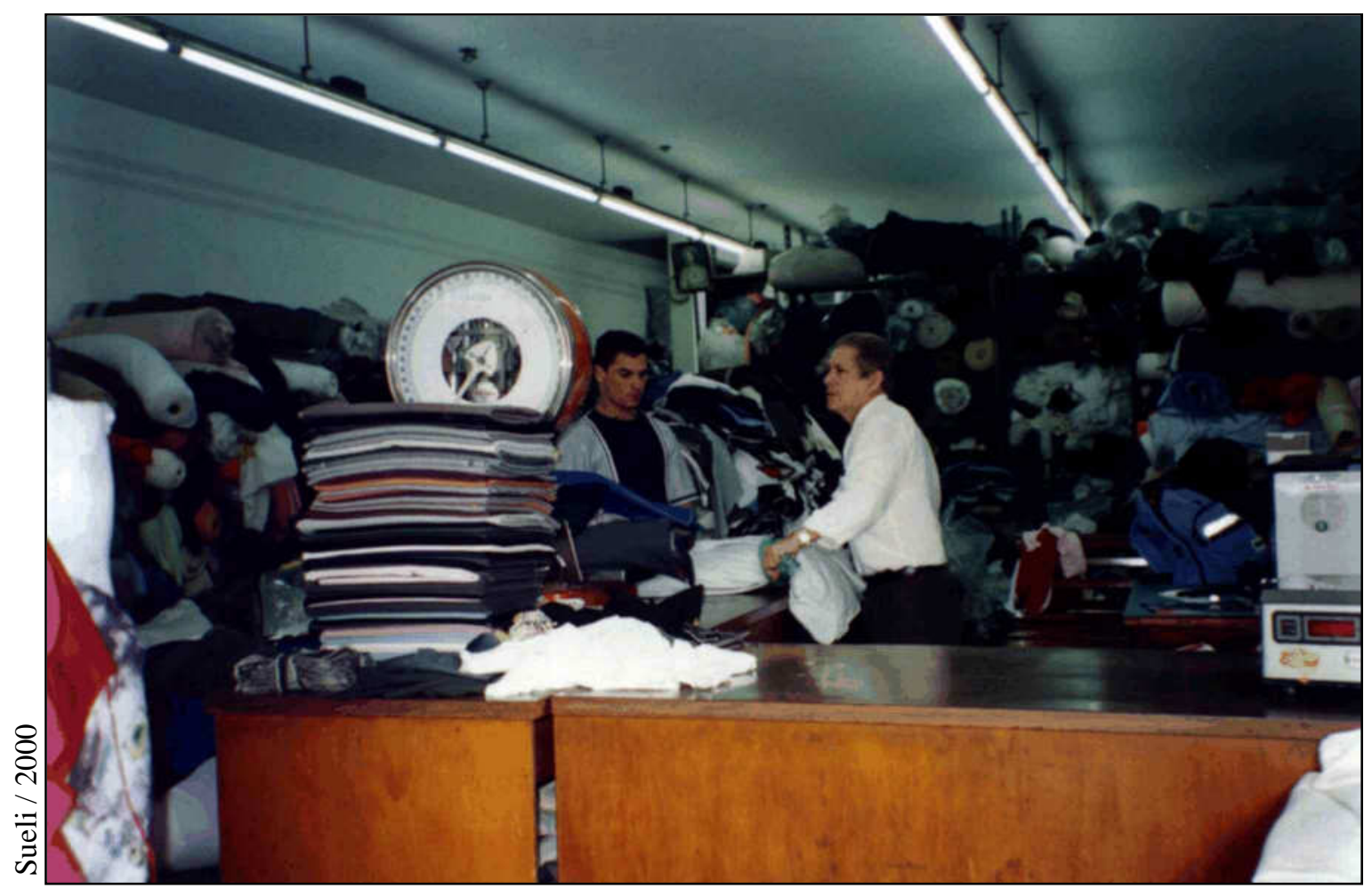

Foto 67: Sr. Simião, de Iguatu - CE e seu funcionário, pernambucano. 


\section{6 "Uns foi trazendo os outros" - um depoimento}

O depoimento do Sr. Dudu, 82 anos, foi muito significativo para entender como ocorreu esse processo de formação da rede social no comércio de retalhos. Ele foi o precursor dessa atividade comercial. Era um nordestino possuidor de um determinado capital em Pernambuco, proprientário de três padarias - uma em Ibirajuba, em Caruaru e outra em Altinho. A localização dessas padarias são as mesmas da área de origem de maior parte desses migrantes. Isso nos leva a deduzir que o fato do Sr. Dudu ser um comerciante conhecido nessas cidade, fez dele uma referência aqui em São Paulo. Pois a pessoa migra com a possibilidade de encontrar um apoio e trabalho com alguém já estabelecido na Grande São Paulo. Vejamos o seu depoimento:

“Ibirajuba foi o seguinte, eu vim naquela época, aqui pra São Paulo, naquela época eu aqui passei. Eu comprei caminhão, aqui. Eu fiquei, quando eu vim da Maria Joaquina foi chegando aquele povo do Norte, junto a eu, da onde eu estava, eu vim sozinho, naquela época, eu vim sozinho. Eu vim de avião, fiquei por aqui. Vim primeiramente a passeio, aqui. Aí, depois desse passeio, aí eu volto para morar com a família, aí fiquei por aqui. Aí, o povo pegaram, chegaram do Norte, aquela família, aquela família, aquele conhecimento meu, vieram do Norte, aí fui colocando eles pra trabalharcomigo, trabalhar comigo aqui no depósito de retalho e chegava trabalhar, pegaram, trabalhar também, tudo esse povo daqui ao redor, quase todinho, (...) depois de mim, mas o antigo, o mais antigo no retalho, fui eu, ali na Maria Joaquina, foi quem fundou. Na Maria Joaquina só tinha lojinha de retalho, era eu. Depois do retalho, eu tinha uma casa, um bar. Depois do bar, eu fiquei só com retalho. Só com retalho, então, é quarenta anos de luta e trabalho. Em Ibirajuba eu era dono de padaria. Tinha padaria. Naquela época eu tinha três padarias. Eu tinha uma padaria em Ibirajuba. Uma padaria em Caruaru e uma padaria em Altinho. Padaria. Eu trabalhava com padaria. Aí depois, eu vim embora prá São Paulo, passear. eu gostei de São Paulo. Aí fiquei. Eu resolvi vim morar em São Paulo, em 1960. Aqui, sempre trabalhei por minha conta... Fui vendendo as minhas coisas, ainda, fui vendendo um bucado de coisa que eu tinha lá, umas casas, ainda eu tenho casa lá, na cidade. Aí fui vendendo umas coisas e fui trabalhando e fui... Comprei casa para morar, 
também, que eu tenho casa própria. Isso aqui é própria, é do filho, já comprou, também, com a luta do trabalho. E então foi isto. Agora, meu conhecimento aqui foi com Acássio de Oliveira, seu Acássio me arrumou, tinha... (...) na Cachoeira, pra mim. Miranda era na Cachoeira, também, lá em cima. Era gente que foi do meu tempo, agora Batista, também, um tal de Batista, foi do meu tempo, também, tinha uma pensão. Depois comprei a pensão dele. Depois, vendi de novo pra ele. Aquele negócio de jogada de trabalho. Na Maria Joaquina eu passei 28 anos. Só na Maria Joaquina eu passei 28 anos. ” (...)

Q: Qual foi a primeira pessoa que o senhor introduziu [no comércio]?

"Eu nem me lembro mais. Foi tanta gente que veio pra trabalhar. Tanta gente, aí, que veio pra trabalhar, comigo, naquela época. Eu nem sei dizer quantos vieram trabalhar e depois foram comprar, abriu lojinha, trabalhando, tem muito mais de 50 pessoas, aí. Naquele tempo, que colocou, que veio do Norte tem muito mais de 50 pessoas, aí.” (...) “Não parente, não. Alguns parentes, outros, vêm de fora, que veio e me procuraram, [Q: de Ibirajuba?] de Ibirajuba, me procuraram e eu acolhi aquele povo, família chegava, eu... minha casa tem um lugar que tinha dia, que tinha 20 tantas pessoas. A pessoa vinha do Norte, eu acolhia. Eu aluguei uma casa, aqui, na rua João Boemer, aluguei uma casa só para receber o povo que vinha do Norte e não tinha meio de vida. Eu aluguei uma casa, aqui; fiz quarto, compartimento, arrumei bem, lá, também, eu fiz. Tinha tempo que eu tinha 20 ou 30 pessoas, que vinha sob a minha responsabilidade. E eu ensinando a trabalhar. Foram aprendendo a trabalhar e depois tomaram conta de si, todo mundo. Veio família para a minha casa, o pessoal lá em casa, todo pagava a conta (...) a família de (...) vieram tudo pra qui. Vieram (...) fala isso hoje, eles vão achar, até, ruim, o pai deles, eu acolhi. O pai veio aqui, eu acolhi. E ... alguma coisa, e trouxe a família, também. Deixava a família aculá e vieram tudo. Tem muita família que eu... (filho fala) Só vinha ele pra cá, (de amigo). Veio só. O Batista veio só. Batista que eu falei (...). Veio muita gente, por aí. (...) Depois trazia a família, depois arrumava a casa, eu afiançava a casa (...) uma pessoa que chegou, eu acolhi, isso faz uns uns 15 anos mais ou menos, alugava 
a casa, afiançava a casa, pra ele, dá o ponto pra trabalhar, dá comida, enquanto ele não equilibrasse. Arrumar (...) uns não queria trabalhar no comércio, queria emprego eu arrumava emprego, arrumei muito emprego, pra muita gente. Mais trabalho, botava mais o pessoal pra trabalhar. Agora comigo, quando tava certo no comércio, que tinha tino pro comércio, eu botava ele no pontinho, ele ia trabalhar, e eu ensinava a trabalhar como é compra o pano, como vende. E assim, fui levando a vida, até hoje, tô ainda, tem gente, às veis, eu ajeito...

Q: Teve algum recentemente?

D: Não aqui em São Paulo, parou, porque é o seguinte. Hoje eles sabem que eu tô trabalhando menos. Eu tô trabalhando menos. Meu filho que tá enfrentando o negócio. Eu tô somente andando e... pro Norte, pra ali, pra aculá. Que eu tenho as minhas casas no Norte, ainda. Minhas coisas no Norte, tenho um bucado de coisa lá, no Norte. Eu tô para viajar prá lá. O povo... quando ainda vem. Tem gente começou a trabalhar depois da gente. Tem dono de prédio, lá pra cima, pro outro canto. Muita gente vem. (...) Trabalhou depois de mim. tudo aprenderam a trabalhar, depois de mim. Já, lá, na Maria Joaquina, mesmo, ali tem muita gente que saiu dali. Depois, já foi gente, (...) foi trabalhar, mesmo, já na... Monteiro Lobato, Largo na Concórdia, naquele tempo. Ele foi trabalhar, que eu arrumei casa, pra ele, lá. Ele abriu loja, lá (retalho). Veio junto, também, do Norte, veio trabalhou comigo, também, um tempo, e foi embora... Aqui em São Paulo não vevi, não... (...) Alguma pessoa sabe, sabe que agente ajuda, faz o que pode fazer, quando que a pessoa melhora de situação, ninguém vê mais a pessoa. [Q: Esquece?] Esquece. Aquele, menino, mesmo; eu botei a ele pra trabalhá, naquela época, esse não vi, mas faiz mais de vinte anos. Dei negócio, comprei um bar, pra ele, trabalhou comigo. Depois, eu dei um negócio, a ele. Esse eu não vi mais; porque esse povo é o seguinte, eles muita gente, eles quem é que fica a única pessoa à vezes fala, às veiz, que eu ajudei a vim fulano, porque eu também não falô. Tô falando porque tô dando a entrevista... mas num falô... como se diz, eles trabalharam, vieram trabalhar; aqueles que tinham vocação para equilibrar na vida. Equilibraram. E assim muitos que não quer nada, né, também, que às veiz, 
não quer trabalhar, não. Tem muitos, às veiz, teve, também, elemento que foi pra me embrulhar, pegou um dinheiro meu, um espólio, desapareceu. Muitos deles. Eu abri negócio, aí, butava eles, acabava, robava tudo. Ainda aconteceu. [Q: conterrâneo?] Conterrâneo do Norte. É, o bicho, não era da minha cidade, mas foi de fora. Teve um cara que ficou aqui. Eu abri um negócio na rua João Boemer, e butei pra ajudar, pra trabalhar, fiz uma viagem com o filho. Foi-me embora com tudo. Todo tipo de caminhão, ele carrego. Era do Recife, ele. Fui apresentado pelo um amigo, meu. Era um negócio. Um negócio, naquele tempo eu trabalhava com negócio de... era um armazém, de cereais, aquelas coisas e ele, cheguei não encontrei... só encontrei a loja fechada e ele..., e o aluguel para pagar. Aconteceu tudo isso. Mas, essa vida é assim mesmo. Nem todo mundo é aquela beleza. A humanidade... Mas, eu não tenho que falar de ninguém, não. Pra mim, tá tudo bem. Alguém que tá feliz, muitos felizes. Eu, também, tô muito feliz. Graças a Deus. Só encontro felicidade. (...) Todos os meus filhos. tá no ramo de pano de tecido Já tenho um neto trabalhando. [Q: Parente?] Cunhado. Deixo vê se eu tenho algum cunhado. Não veio mais nenhum, pra cá. Porque um... Batista que eu butei numa loja, que era um cunhado meu, mas não quis prosseguir, trabalhar. Quis deixar o ramo. Mudou Arrumou emprego na Swift, foi trabalhar na lá. O outro meu cunhado foi trabalhar na Goodyear. Não quis trabalhar comigo no ramo. Tem goodyear. A goodyear é perto da minha casa. (...) A maioria é de Ibirajuba,... ajuda muito, né de Altinho, Cachoeirinha, o povo dali vem de Lagedo, muitas famílias vieram. Porque umas,... aí (...) foi se enraizando. Uns foi trazendo os outros. (...) Conhecido de Ibirajuba e outros vinham mandado pra me procurar 'Procura, lá Dudu,lá, de Ibirajuba, em São Paulo que ele sabe' tinha mesmo, aquele, mesmo, Batista, Zé Genoino, foi tudo mandado. Conhecia lá. Uns me conhecia, outros não. (...) Essa casa eu dei de graça, pagando água e luz, pra eles. Apoiei eles todinho, pagando água e luz. Eles morando, recebendo a família. Tinha um terreno nos fundos, eu construí pra chega gente, bota mais, e uns, já foi-se embora pro Norte. Nessa casa passei 30 anos, com ela. Essa da João Boemer. Foi vendida o ano passado. A moça, a dona queria vender. Pediu que entregasse o prédio dela... eles moravam ou não, não cobrava. Depois, quando foi com o tempo que eles melhorado, eu falei para que eles pagarem a luz e água, eles não quiseram 
pagar nem luz e água. Aí depois, foi que o Major, aí alugou uma parte, lá, e pegou pagar luz e água. Aluguel é difícil pagar; aluguel... eu morei dezoito anos, nunca deu um tostão. Eu dei uma casa pra ele. Construir uma casa pra eles vim morar (...). Eu dava um apoio, tinha, porque quando eles chegavam, quando não tinha casa, eu butava na minha casa, muita gente eu butei na minha casa. Família... Aí, depois, com um mês ou dois. Um ia procurando uma coisa, outro procurando outra, arrumava um emprego. Aí, saiam, alugavam e ia morar. E aí depois eu peguei aluguei essa casa aqui, na João Boemer e aluguei outra essa casa, que eu tinha, em cima na Maria Joaquina, pra butar o povo que chegava, pra ficar trabalhando e eu ficar... e ficar no canto deles.”

Q: Nem todo que o senhor ajudou foram para o comércio?

“Muitos arrumava o emprego, não era no comércio. Uns no comércio e outros... no comércio. [Q: a maioria?] Era. Era trabalhar comigo, depois, aprendia a trabalhar; comprar o retalho, iam vender. (...) Quando eu cheguei com uns 80 anos, parei uma pouco... a minha vida só foi receber gente do Norte... ficar com eles aqui, encaminhar e parece que eu vim do Norte... Uma casa para morar, tô vivendo a minha vida, graças a Deus, criei meus filhos na honestidade, tô vivendo a minha vida, Graças a Deus, nenhum problema financeiro, eu tenho minha casa, não vou dizer que arrumei, mas encaminhei muita gente. (...) Aonde eu vou, o povo. me mudei aqui faz mais de 2 anos, já chegou mais de 20 aqui... aonde eu abro um negócio vem o povo atrás. Não é Moacir? Não é assim, aonde eu abro um negócio, o povo não vem atrás? [Vem- responde seu filho]. Eu fui lá, na Maria Joaquina, lá, era loja em todo quanto é canto, lá. O povo cresceu. Valorizou muito a loja, ali não tinha o valor que tem, entendeu? Hoje, é um valor enorme, ali muito valorizado. No meu tempo, não tinha valor, quase nada. Eu tive, também, restaurante, aqui. Depois, vendi o restaurante e fiquei só com um bar. (...) Eu mexia com cereais, também. Cereais, eu mexia com negócio de feijão, arroz, negócio... comprava galinha, vendia, tipo armazém, armazém, sim. (...) Já era em outro lugar. Eu tinha noutro lugar, tomava conta um cunhado meu, naquela época; era na Maria Joaquina... Era rua Joly. 
[fechou e ficou só com retalho]. Fiquei só com retalho. Aluguei o lugar pra outro negócio, lá, naquela época, meu cunhado. Era um armazém. Aí, eu aluguei. Eu “subalugava”, lá, o proprietário me deu autorização... aluguei 28 anos, construindo, alugando, negociando, até quando venderam o prédio, aí foi que eu saí. Eu mexia com outros negócios, também. Tinha Família. Minha família sempre estudando, trabalhando, Ia tocando o negócio.”

Esse depoimento revelam algumas contradições presentes na formação dessa rede social. O Sr. Dudu cria uma estrutura para receber os migrantes na Rua João Boemer. Ele pagava todas as despesas desses migrantes e identifica esse ato como uma "acolhida", deixando em destaque o sentido da solidariedade. Mas em outros momentos de seu depoimento revela que esses migrantes não reconhecem esse "ato de solidariedade". Vejamos:

“Alguma pessoa... ninguém vê mais a pessoa."

“... estes trabalharam, vieram trabalhar; aqueles que tinham vocação para equilibrar na vida equilibraram. E assim muitos que não queriam nada.”

Assim, a casa da Rua João Boemer era como um alojamento dos seus trabalhadores que passa a revelar o ato da troca do trabalho por essa estrutura - "o apoio". Assim, esses migrantes vinham para trabalhar para o Sr. Dudu, que tinha uma mão-de-obra farta. Havia uma mobilização entre os migrantes já estabelecido com o recém-chegado e vice-versa, como já discutimos, anteriormente. Outros aspectos significativos aparecem em sua fala, como a quebra da confiança entre esses conterrâneos, a expansão da atividade nas ruas do Brás, e a formação e controle dessa rede de migrantes no comércio de retalhos. 


\section{O TRABALHO AUTÔNOMO E O MIGRANTE}

\subsection{O trabalho por conta própria no comércio de retalhos}

Ao investigarmos as razões que levaram esses migrantes a se inserirem no comércio de retalhos encontramos alguns elementos importantes para entender a presença dos migrantes nordestinos no comércio de retalhos.

O primeiro elemento significativo é a baixa escolaridade entre os retalheiros, pois a atividade comercial não exige um nível de escolaridade como em outros empregos na cidade de São Paulo. O segundo fator presente nessa atividade é a exigência de um pequeno capital ou até nenhum, é o caso dos catadores de retalhos, que às vezes, nem possuem seu carrinho, trabalhando inicialmente nos depósitos. Dependendo do capital empregado esse migrante se encontrará em uma das funções do comércio de retalhos, às vezes mais capitalizado, às vezes menos capitalizado.

Outro elemento bastante presente nos depoimentos, quase unânime, foi a comparação entre os rendimentos no mercado formal, ou até nos subempregos, inviabilizando as suas condições de reprodução e de sua família. Vejamos o depoimento abaixo:

"Quando precisa, entendeu, divide pra família inteira. (...) Empregado tem um salário que pela amor de Deus, a família que a gente tem, um salário não ia dá pra nada. pão, leite, não ia dá pra nada; então é melhor sofre assim. (...) Eu acho que não dá pra uma família vivê, eu acho que não dá.” (Teresa)

Esses fatores faz com que o migrante procure formas alternativas de trabalho, tornando-se um trabalhador por conta própria. Essa constatação, também aparece nas pesquisas de PRANDI (1978), LIMA (1987), CACCIAMALI (1983) e MENEZES (1990), MARTINS (1979) e DOMBROWSKI (2000) ${ }^{31}$.

\footnotetext{
${ }^{31}$ Constatou-se o baixo nível de qualificação no trabalho informal, mas em relação aos rendimentos mensais essa pesquisa indica um menor rendimento, se comparado com o trabalho formal, na média.
} 
Vejamos a conceituação de PRANDI (1978) sobre esse trabalhador autônomo, também denominado "conta-própria”, enfim que não possuem vínculos empregatícios:

"Como categoria o "conta própria" reúne grande diversidade de trabalhadores para os quais o desempenho de tarefas, no âmbito da divisão social do trabalho, depende quase que exclusivamente do dispêndio da força de trabalho de membros da família - , necessitando de baixa quase nula capitalização. São os artesãos, os ocupados em serviços de reparação $e$ pequenos consertos, os prestadores de serviços pessoais e muitos outros conhecidos da paisagem das cidades brasileira, pequenas e grandes”. ( $p$. 25)

A OIT (Organização Internacional do Trabalho) faz um estudo sobre o trabalho informal e uma classificação das diferentes categorias desse trabalhador, entre eles o autônomo. Segue abaixo sua definição:

“pessoa que explora seu próprio negócio ou ofício e presta seus serviços diretamente ao consumidor ou para determinada(s) empresa(s) ou pessoa(s)." (JAKOBSEN, 2000: 8)

O trabalhador autônomo é uma das formas de inserção na estrutura produtivas. Existem muitas pesquisas que vão estudar principalmente os camelôs e o comércio ambulante como SOUZA (1984), BARROS (1988), MONTEIRO (1993), MARIANO (1997). BARROS faz a seguinte relação entre a migração e a economia informal:

"No processo migratório, as massas de população conduzem consigo formas de reprodução sócio-econômicas que devem, como já foi afirmado, reproduzir-se em contextos urbanos os mais diversos." (p. 109)

MENEZES (1990) faz a seguinte análise da presença do migrante como autônomo: 
"A expectativa do migrante em trabalhar por conta própria não se explica apenas pelas características, intrínsecas desta relação de trabalho, mas antes pelo conjunto das estratégias de sobrevivência, nas quais ele pode se engajar, com o objetivo de sustentar a si e sua família." ( $p .24)$

JAKOBSEN (2000) aponta a origem do trabalho informal na América Latina e no Caribe relacionada à forte migração de trabalhadores do campo para a cidade após a Segunda Guerra Mundial, devido às transformações no campo, somadas à busca de melhores condições de trabalho na cidade que se industrializava. Há insuficiência oferta de emprego para atender a essa demanda.

"Isto levou uma parcela expressiva destes migrantes a constituir um excedente de mão-de-obra, que foi obrigado a "inventar" seu próprio trabalho - principalmente no comércio e no setor de serviços - como meio de sobrevivência." (p. 14)

Existem alguns problemas e dificuldades que o migrante enfrenta em seu cotidiano no comércio de retalhos. Um deles é a condição das mulheres que se desdobram como donas de casa e retalheiras. Os comerciantes retalheiros destacam as seguintes dificuldades nessa atividade - a primeira é a suceptibilidade aos roubos e à violência urbana; a segunda, são os cheques sem fundos, que são constantes nessa roda de negócios; e a terceira é o enfrentamento com a fiscalização da atividade, remetendo aos últimos fatos das propinas dos fiscais ${ }^{32}$ que pressionam os migrantes/comerciantes para manterem a sua atividade funcionando. Outra dificuldade que o comerciante de resíduos e retalho passa nessa atividade é a conversão de uma mercadoria sem nota fiscal para uma mercadoria com nota fiscal, que ele "cria" para essa seguir viagem.

Apesar dessas dificuldades que afetam em comum os comerciantes de retalho, não encontramos nenhuma associação ou sindicato que respondesse por esse grupo. Quando questionados o porquê da inexistência de uma representação ou de uma organização que unificasse o grupo, a maioria não soube responder. Apenas um dos entrevistados, um retalheiro antigo, disse de uma tentativa sua, mas que não obteve 
resultado. Existe um distanciamento entre os comerciantes, que se unificam na rede de relações, mas que não se identificam enquanto uma categoria. Outros apontam a intensidade do trabalho que não permite a preocupação com uma união entre os comerciantes. O comerciante tem a rua como referência de lugar, mas muito mais a loja ou o depósito que está confinado, salvo o correntista. Quando perguntamos sobre a relação entre os cearenses e pernambucanos nesse comércio, apareceu um certo distanciamento. As relações ocorrem mais perpassando pela rede familiar e de apadrinhamento, que discutimos capítulo anterior.

\subsection{Hierarquias no interior do comércio de retalhos}

O comércio de retalhos aparece com diferentes níveis de acumulação. Esses níveis de acumulação decorrem do tempo em que o comerciante permanece na atividade, considera-se, também, o capital inicial que foi empregado, no trabalho que ele exerce nessa rede social, que é hierárquica. $O$ processo de circulação de mercadoria exige não apenas as diferentes tarefas, mas também diferentes tipos de trabalhadores se especializam em uma dessas tarefas.

O primeiro tipo de trabalhador que destacamos é o correntista. Normalmente ele não aparece no espaço da loja, pois fica circulando pelas ruas do Brás ou até mesmo viajando na procura de um lote para a compra, sempre em busca de um bom preço e boa venda nas lojas de retalho. O correntista, geralmente, compra das lojas de confecções $e$ vende para outros retalheiros, criando uma especulação em torno da mercadoria até esta ser vendida para o comerciante que possui a loja, ou até ir para outros locais do Brasil. Seu trabalho se assemelha ao de um leiloeiro ou corretor de imóveis, negociando os preços e oferecendo os chamados "lotes". Às vezes, trabalha de forma independente nas lojas e, muitas vezes, tem uma relação de interdependência com a unidade comercial, o estabelecimento - loja. É uma figura bastante nebulosa, pois ele se diz autônomo mas muitas vezes trabalha ganhando uma

\footnotetext{
${ }^{32}$ Para entender melhor o grau de organização da corrupção na fiscalização realizada pela Prefeitura ler o livro “A Máfia das Propinas” de José Eduardo Cardoso.
} 
porcentagem para um determinado lojista com firma aberta que funciona de fachada para vários outros correntistas. Às vezes em uma mesma loja trabalham quatro ou cinco pessoas e cada uma se diz autônoma ganhando uma porcentagem da compra feita, que é passada para o lojista que realizará a venda. Esses correntistas, normalmente, usam o telefone da loja para procurar a venda. Eles se autodenominam como um trabalho autônomo, porém o seu ganho, se assemelha a uma forma de remuneração. Pois, ele recebe por produção e porcentagem, o quanto ele conseguiu fazer negócio, sendo que quem paga a mercadoria é o proprietário da loja. Ser autônomo, para ele está relacionado ao não ser controlado em seus movimentos e depende somente deles próprios o seu ganho. Outro tipo de corretor é aquele que vende nas lojas de retalhos que não têm acesso à indústrias de confecção e têxteis. Esses corretores não têm horário e nem nenhum compromisso trabalhista; não se preocupando com o registro em carteira.

O segundo tipo de trabalhador que parece no cenário em destaque é o retalheiro/ dono da loja que trabalha com as peças maiores de tecido, mais o retalho e um pouco de resíduo. Ele é o proprietário de lojas que possui um certo grau de acumulação em mercadoria. Essas lojas, na maior parte, começaram com um capital maior e não passaram por todo um processo evolutivo dos antigos retalheiros. Essas unidades de comercialização têm na sua maior parte, mulheres trabalhando para o complemento da renda familiar, sendo que o marido trabalha em outra profissão. Outras vezes, são famílias, onde já trabalharam em outros ramos do comércio.

O terceiro tipo de trabalhador que destacamos é o retalheiro que apenas separa os retalhos; eles os compram das confecções, os escolhem e os vendem para os correntista ou os donos da loja. Há uma simplificação: há os donos de depósitos, e também os catadores. O retalheiro pode estar em duas condições diferentes: a primeira condição é aquele que possui o seu próprio depósito e a segunda condição é aquele que não possui depósito e trabalha em um local que não lhe pertence, ele separa ou escolhe os retalhos para comercializá-lo.

Os correntistas, com o lote já separado, vendem para a loja que venderá para as costureiras ou para outros pontos do país, principalmente Santa Cruz do Capibaribe (PE). A venda para Santa Cruz do Capibaribe é realizada por nordestinos que se 
especializaram nesse intercâmbio e que podem ser os próprios donos das confecções, ou funcionários, ou uma espécie de atravessador. Esses comerciantes pernambucanos, geralmente, ficam nos hotéis, quando vêm a São Paulo e levam para o Nordeste retalhos e armarinhos (botão, zíper etc.). O transporte é realizado por uma empresa especializada, que busca o lote nas lojas, depósitos ou tecelagens e entrega em Pernambuco, como registramos em capítulos anteriores. O grau de acumulação, também, depende do tempo do retalheiro no ramo, normalmente, começam trabalhando com o resíduo sem instalação certa. O local, geralmente, é emprestado, tem um tamanho pequeno, e os retalheiros iniciam a atividade apenas escolhendo, para depois, também, comercializar os retalhos. Desta forma, vão ampliando o mercado e, por conseguinte, a acumulação; o ideal é não fazer estoque e sim, possibilitar o maior giro da mercadoria. É nesse momento que o retalheiro passa a trabalhar com resíduo e também, com o retalho. A acumulação proporciona ao retalheiro manter o aluguel, primeiramente de um depósito e, posteriormente, vários depósitos ou lojas. Essa seria a trajetória do retalheiro e as várias funções e níveis de acumulação diferentes que encontramos nesse comércio.

PRANDI (1978) em seus estudos faz uma discussão sobre a estratificação social. Para o autor há uma divisão de uma "massa marginal", que é o trabalhador por conta própria de baixo rendimento e os trabalhadores por conta própria bem sucedido. Os marginais" procuram alcançar "as oportunidades sociais" e por níveis razoáveis de consumo. O estudo "A Família Trabalhadora” de WOORTMANN (1984) revela que não devemos equacionar "setor informal", ou produção doméstica, com marginalidade, subemprego ou pobreza. Vejamos a sua afirmação:

"Essas atividades freqüentemente constituem não estratégias de sobrevivência, mas mecanismos de acumulação e de ascensão social." ( $p$. 69)

Em nossa pesquisa observamos os diferentes níveis de acúmulo e a hierarquia social que perpassa o comerciante de retalhos. Assim vender resíduos, retalhos, ter depósito, loja são formas de ascensão social. 


\subsection{Migrante: sujeito sujeitado e o sonho da liberdade}

Outro aspecto que se evidencia em nossa pesquisa é entender por que uma parcela dos migrantes prefere o trabalho autônomo ao trabalho assalariado. O trabalho autônomo seria uma opção ou uma condição? Observando essa questão tanto na época do início do comércio (década de 70) quanto nos dias de hoje. Qual o significado da atividade autônoma para esse migrante? Quais são os sonhos e as expectativas desse grupo de migrantes?

Entre os sonhos, expectativas e planos mais imediatos destacamos, novamente, o retorno do migrante, entretanto um retorno que não se realiza, pois os elos familiares, imobilizam o migrante. Os mais antigos sonham em voltar para o Nordeste, porém os jovens não. Assim, os velhos retalheiros, presos pelos laços familiares construídos em São Paulo, apesar da saudade da sua terra de origem, voltam apenas para passear. Os migrantes afirmam nos depoimentos da sua intenção em continuar no ramo e deixá-lo de herança para os seus filhos.

Todos os retalheiros, quando interrogados se gostam de trabalhar como autônomos, responderam que sim, à exceção de um caso que possui grau de instrução superior. A preferência se dava porque dessa forma, a pessoa tinha mais controle sobre si, pois não tinha patrão, horários e assim uma maior liberdade. Outro fator levantado foi a remuneração insuficiente que se tem hoje para sobreviver; vejamos:

"Ele se cansou de trabalhar de empregado, a gente trabalhar de empregado a vida é muito dura, o que ganha mal dá para comer, a pessoa tem que procurar uma melhorazinha. A pessoa trabalhando de empregado, maior fome. Ele melhorou um pouquinho trabalhava na Volkswagen, firma de empregado, era metalúrgico." (J.B.Z.)

"Porque a pessoa trabalhando por conta própria, a retirada é melhor, a retirada é melhor vive uma vida que não é subordinada a uma firma, um horário de trabalho, com a marcação de cartão, chega atrasado, não tem problema nenhum."(Ismael) 
Os retalheiros que estão iniciando na atividade e não possuem nenhum capital inicial, têm a tarefa de apenas separar os retalhos. Esses fazem do mesmo local, a loja, um depósito e simultaneamente sua moradia, atenuando, assim, o custo de sua reprodução, pagando um único “aluguel”. Nesse caso, a privacidade é totalmente invadida pelo comércio. O retalheiro se desdobra e se desgasta, pois usa o seu tempo livre com o seu trabalho. Mesmo esse se identifica como trabalhador "autônomo". Uma pseudo autonomia, pois ele perde o seu poder sobre o seu tempo livre que é dominado pelo comércio.

Para poder responder a essas questões buscamos em PRANDI (1978) e MENEZES (1990) estudos que mostram os desejos do indivíduo de romper as regras de horários, ser dono de si, procurando, enfim, a sua autonomia. Na pesquisa de MENEZES (1990), a autora constata o desejo dos migrantes residentes em São Paulo de trabalharem por conta própria, pois abre possibilidades de um ganho maior do que o salário fixo, além de lhes permitir "liberdade",

"tendo em vista ser uma relação de trabalho sem a presença do patrão el ou chefe sem horários fixos e outras regras próprias da relação de trabalho assalariada” (MENEZES, 1990: 23).

A autora segue a reflexão:

“Assim, além dos aspectos econômicos do trabalho por conta própria, temos que considerar também que o desejo de se engajar em tal relação de trabalho por parte dos migrantes expressa uma forma de resistir à nova organização do trabalho assalariado, seja fabril, na construção civil, no comércio, ou nos outros setores.” (MENEZES: 1990, 25)

Segue a análise de PRANDI (1978):

"Na impossibilidade de vir a se transformar em empregador, o trabalho autônomo traz em si a oportunidade de negar, pelo menos, a condição de assalariado. Mas o trabalho por conta-própria significa também a possibilidade de trabalho para os que não conseguem ser assalariados." (PRANDI, 1978: 85) 
São então processos conjugados, pois "a expulsão pode estar mascarada como opção". A expulsão ocorre quando suas habilidades não the permitem mais competir no mercado (sexo, idade, condições físicas). Assim o autor conclui: “A opção só é possível se o trabalho específico for socialmente útil. A possibilidade de opção assim é determinada." (p. 87)

Existe uma contradição no migrante, trabalhador autônomo, pois ao mesmo tempo que nega o assalariamento, ele se sujeita à mobilidade forçada. Conforme vemos a seguinte afirmação:

"Por mais forçada que possa ser a partida, a imigração é também muito largamente interiorizada pelos imigrantes como meio de acumulação individual destinada a assegurar o regresso ao país, quer como pequeno investidor, pequeno comerciante, quer como pequeno artesão. A exploração forçada é freqüentemente suportada na medida em que, no fim, há a imagem de uma casa, de uma camioneta, de uma garagem, de uma pequena loja... Daí resulta a ambigüidade de muitas situações.” (GAUDEMAR, 1977: 40)

A 'liberdade' da condição do trabalho assalariado foi discutida por GAUDEMAR (1977), apoiado no movimento de um grupo de marroquinos, em uma fábrica da França, que optou pelas demissões. Assim o autor reforça as outras dimensões da mobilidade do trabalho

“..., como os lugares de inserção e de manifestação da mobilidade do trabalho, todos os espaços de sujeição dos corpos produtivos". (p. 53)

E ele conclui que

"Por trás da proclamada liberdade de movimento esconde-se de fato o interesse que aí se encontra o capital.” (p. 59)

Tanto VAINER (1996) quanto GAUDEMAR (1977), baseados em MARX, discutem a dupla dimensão da Liberdade sob o capital, a liberdade positiva considera a livre circulação do trabalhador e a liberdade negativa, o obrigado a circular porque é despossuído dos meios de produção.

Vejamos a seguinte afirmação, que contextualiza a expansão do trabalho informal em São Paulo, diante do desemprego estrutural presente na metrópole: 
"Os mercados do trabalho informal são o desaguadouro de toda força de trabalho que desistiu de procurar emprego ou deixou de contar com suporte material para fazê-lo." (SINGER, 2000: 12)

Então, “embora alguns apreciem a 'autonomia' do trabalho informal, a maior parte deles está na informalidade em razão do desemprego e a ampla maioria tem como demanda comum a regulamentação da atividade." (p. 9), conforme a afirmação de JAKOBSEN (2000) na publicação organizada pela CUT, Mapa do Trabalho Informal. Segundo os dados do IBGE, em 1998, eram 2,6 milhões de indivíduos, maiores de 10 anos, correspondendo 48,2\% dos trabalhadores ocupados encontram-se em atividades consideradas informais.

Outros autores mostram o desejo e o sonho do migrante em se tornar um trabalhador por conta própria como MARTINS (1979), que em seu livro O Cativeiro da Terra cita a vontade e o desejo dos migrantes italianos de possuírem as suas próprias terras e serem autônomos. Outro autor que demonstra esse processo é SILVA (1997) com o estudo dos bolivianos em São Paulo. Dessa maneira pensamos também o trabalhador autônomo que procura fugir das regras da empresa que controla seu tempo e seus movimentos. Entretanto, contraditoriamente esses estão expostos as longas jornadas de trabalho, discutida também em outras pesquisas, e as dificuldades do cotidiano do comerciante, já discutidas anteriormente.

Os desejos de autonomia, de ter o seu próprio negócio e os seus sonhos, aparecem entrelaçados com a vontade de fazer parte, de estar incluído como segue a reflexão de MARTINS (1988a). Esse migrante nada mais é do que um sujeito sujeitado, processo analisado por KURZ e pelo grupo KRISIS como vemos a seguir:

“Mas, mesmo pagando o preço da auto-resignação, o admirável mundo novo da economia de mercado totalitária deixou para a maioria das pessoas apenas um lugar; como homens submersos numa economia submersa. Submissos aos ganhadores bem remunerados da globalização, eles têm de ganhar sua vida como trabalhadores ultra baratos e escravos democratas na 'sociedade de prestação de serviço'. Os novos 'pobres que trabalham' têm direito de engraxar o sapato dos businessmen da sociedade do trabalho ou de vender hambúrguer contaminado, ou então, de vigiar o seu shopping 
center. Quem deixou seu cérebro na chapeleira da entrada até pode sonhar com uma ascensão ao posto de milionário prestador de serviço.” (KRISIS, 1999: 16)

De forma irônica ele coloca a questão do trabalho nos dias de hoje, as pseudo possibilidades que existem, em que o prestador de serviços sonha em ser dono dos meios de produção, ou seja, os inclusos de segunda categoria sonham em ser os consumidores de primeira categoria, sempre fazendo parte dessa estrutura e não rompendo com ela. O texto ainda segue denunciando a lógica da inclusão nos dias de hoje colocando o "subemprego" como exemplo de iniciativa privada, para um enorme exército de desempregados:

“ 'O modelo para o futuro é o indivíduo como empresário de sua força de trabalho e de sua própria previdência social', escreve a 'Comissão para o Futuro dos Estados Livres da Baviera e Saxônia'. E ainda: 'a demanda por serviços pessoais simples é tanto maior quanto menos custam, isto é, quanto menos ganham os prestadores de serviço'. Num mundo em que ainda exista auto-estima humana, uma frase deste tipo deveria provocar uma revolta social. Porém, num mundo de animais de trabalho domesticados, ela apenas provoca um resignado balançar de cabeça.” (KRISIS, 1999: 17)

Nesse contexto, do mundo modernizado, pós-revolução técnico-científica, as instituições apontam para a saída do desemprego estrutural, o trabalho por conta própria; dessa forma vemos que essa atividade não é uma escolha, mas sim uma condição, quando vemos a afirmação:

“... a concorrência priva o homem de todo o sossego, ...; destrói grande número de existências...; priva massas humanas , em escala cada vez maior, da satisfação de suas necessidades, mas também desenvolve, em escala cada vez maior, as necessidades das massas e 'barateia" (Marx) certos bens até então reservados para o consumo de luxo de alguns poucos, incorporandos ao consumo massas; desumaniza os homens, fazendo deles meras máscaras do dinheiro, mas ao mesmo tempo os humaniza, transformandos-os em sujeitos (por enquanto abstratos, condicionados, constituídos), ao destruir 
todos os fetiches naturais e poderes institucionais, sob os quais as massas vegetaram como mero acessório propriedade territorial, sem serem sujeitos". (KURZ, 2000: 212)

Dessa forma, aparece o comércio de retalho. O aproveitamento da sobra das confecções permite o barateamento das confecções, para abastecer a população excluída de um consumo de artigos de luxo, entretanto inclusa no mundo das mercadoria ou o chamado sistema produtor de mercadoria.

O comerciante de retalhos carrega em si, ao mesmo tempo, a negação e a afirmação. O trabalhador autônomo ou o comerciante nega o capitalismo quando recusa o trabalho assalariado, entretanto, o afirma quando possibilita a ampliação e reprodução do capital na circulação da mercadoria. Portanto, esse grupo de migrantes possuem contradições que dinamizam o processo de reprodução do capital no modo de produção capitalista. Esse processo específico de inserção do migrante em São Paulo, no comércio de retalhos vai nos auxiliar a compreensão de uma totalidade maior, a formação econômica social capitalista. 


\section{CONSIDERAÇÕES FINAIS}

Tanto o Brás como o pólo da Sulanca formado pelos municípios de Santa Cruz do Capibaribe, Caruaru, Toritama e Brejo da Madre de Deus são espaços transformados que se conectam, fruto do processo de modernização que a racionalidade do capital impõe, quando mobilizam homens e mercadorias.

A força de trabalho dos migrantes mobilizada pelo capital, faz com que sejam produzidas várias formas de inserção na cidade; entre elas está o comércio de retalhos no Brás. O Brás foi um bairro industrial e operário, predominando os migrantes italianos. Esse bairro possuía um núcleo de vida social, em que a proximidade entre as pessoas e os vínculos de relações de vizinhança eram fortes. O processo de metropolização dilacerou esses vínculos, provocando uma fragmentação desse espaço. Era o fim do bairro.

O capital que gera o processo de metropolização mobilizou muitos nordestinos, como força de trabalho que ocuparam as ruas do Brás, e trouxeram elementos do seu local de origem. Esse mesmo capital que mobilizou os italianos, espanhóis, nordestinos, mobiliza também coreanos, bolivianos e outros migrantes mais, em situações diferenciadas. Porém, todos na busca de sua inserção na sociedade capitalista. ${ }^{33}$ Algumas indagações se abrem para novos fluxos migratórios, como: Qual o significado do Brás para os seus 'novos' moradores ? Como se dá a relação social diante da diversidade de grupos de migrantes no Brás? Será que nesse processo de fragmentação, a rua seria o novo referencial dos moradores e comerciantes do ‘bairro'? Como explicar a presença da ANESP, Associação de Nordestinos de São Paulo atuando no 'bairro'? O que são essas associações nesse processo de fragmentação?

O Brás caracteriza-se por ser um centro atacadista interligado, inclusive via internet, com diversas partes do país. O comércio de retalhos se dá com a venda de matéria prima. Esse pólo por sua vez produz uma confecção mais barata que retorna ao Brás como sulanca. A expansão do pólo industrial da confecção- sulanca está relacionada com a matéria-prima, retalho, oriunda de São Paulo e um mercado 
consumidor precarizado que vem principalmente do Norte e Nordeste. O aproveitamento do refugo da indústria do Centro-Sul, barateia o vestuário e possibilita a reprodução de uma população excluída do consumo de artigos de luxo, entretanto, inclusa no mundo das mercadorias. Assim, o Brás e Santa Cruz do Capibaribe são verdadeiros nós que interligam essa malha de homens e mercadorias, uma racionalidade que a modernidade impõe.

Há uma subordinação da indústria de confecção pernambucana com a indústria do Centro-Sul, na compra de equipamentos de produção e matéria prima. Essa subordinação é fruto de um processo de desenvolvimento desigual e combinado.

O comércio de retalhos tem a sua gênese na combinação de três elementos fundamentais: a migração de nordestinos para São Paulo; a expansão da indústria de confecção, controlada pelos coreanos, propiciando farta oferta de resíduos e retalhos; e, por último a existência prévia de um mercado consumidor tanto em São Paulo quanto no Nordeste, dinamizado pela integração do espaço nacional. Assim, essa atividade comercial ocupa as brechas que o capital deixa para a sua ampliação.

A economia da sulanca mobiliza as pessoas e transforma parte do espaço do agreste nordestino. Essa economia vive um paradoxo, pois enquanto economia informal, gera muitos "empregos" e "ameniza" os problemas sociais, porém não contribui com os impostos e o Estado, principalmente a Prefeitura; não tem recursos para arcar com suas próprias despesas com a infraestrutura urbana.

Existe um conflito intenso entre as prefeituras e as associações do Pernambuco no sentido de tentar organizar as Feiras da Sulanca. Cada município tem um processo de organização e formação da feira. As prefeituras tentam ordená-las com cadastros e normas; .entretanto o seu crescimento escapa ao controle do Estado. Cada vez mais, as pessoas buscam a sua inserção nessa economia, que viabilizando um tipo de trabalho informal e precarizado, num tempo de crise econômica em que falta trabalho formal. Desta forma, o mercado da sulanca tende a aumentar.

A prefeitura de Santa Cruz do Capibaribe tem um projeto de organização do "Parque das Feiras" com uma infra-estrutura adequada, porém ficam algumas

\footnotetext{
${ }^{33}$ Há indícios de um novo fluxo migratório, pois encontramos nos últimos trabalhos de campo, foi percebida a presença de africanos que ocupam as pensões, bares e restaurantes.
} 
questões: Até que ponto a prefeitura vai conseguir controlar essa nova forma de ocupação do espaço público? Nem todos os sulanqueiros têm capital para se fazer presente nessa nova feira proposta pela prefeitura. Como será a sua forma de inserção? Com a mudança da Feira do centro para uma área distante da cidade, o que acontecerá com toda a infraestrutura criada em torno da feira e todas as outras atividades que existem em sua função, tais como, o aluguel das barracas, os restaurantes, os "dormitórios", as lojas, os atacadistas?

Enfim, tanto a economia da sulanca, como uma parte do comércio de retalhos e resíduos estão fora do controle do Estado. Essa atividade faz parte do circuito inferior que coexiste, de forma hierárquica, com o superior. Nossos estudos perceberam a interligação desses circuitos que têm a mesma origem: a modernização e a expansão da força de trabalho. O comércio de retalhos e de sulanca mantém a desigualdade e sustentabilidade social, aparecendo como um instrumento no processo de "inclusão"; uma inclusão precária e diferenciada.

A formação do comércio de retalhos está também entrelaçada por redes sociais de parentesco ou de apadrinhamento, entrelaçada por redes econômicas e redes territoriais. Nesse processo de inserção, a rede social é um apoio para os migrantes. No comércio de retalhos ela é difusora de informação; estratégia importante para a entrada do migrante no mercado comercial, além do apoio "logístico" proporcionado pelo conterrâneo. As redes sociais trazem em si contradições como a solidariedade e a concorrência. Muitos de seus elos são rompidos com conflitos e quebra de confiança diante da concorrência comercial. As redes sociais são mecanismos de mobilização dos migrantes como força de trabalho, proporcionando-lhes um acúmulo de capital individual.

O comércio de retalhos amplia-se na medida em que as redes sociais atuam, servindo de apoio, principalmente, com as informações próprias desse mercado. Essa ampliação redefine uma nova configuração espacial, na qual a rede de mercadorias e de pessoas se confundem. O processo econômico incorpora as redes sociais para a reprodução e a ampliação do capital.

Uma vez expulsos do mercado de trabalho formal regulamentado, os migrantes procuram no comércio de retalhos o seu próprio negócio para se inserir como 
autônomo na economia de São Paulo. Observamos que existe uma hierarquia entre esses migrantes, dependendo da função que exercem na atividade - uns mais capitalizados, outros pouco ou sem nenhum capital. Os comerciantes procuram aumentar o seu capital, por pequeno que seja, e assim ascender socialmente. Identificamos três fatores que levam esse migrante a se inserir nessa atividade: a baixa escolaridade; a remuneração acima do trabalho regulamentado, considerando o salário mínimo; e o pequeno ou nenhum capital exigido para o exercício da atividade. O comércio de retalhos guarda, em si, mecanismos de acumulação e ascensão social.

Esses migrantes carregam contradições, pois enquanto trabalhadores autônomos, negam o assalariamento, no entanto se subordinam à mobilidade imposta pelo capital.

O comerciante de retalhos nega o capitalismo quando recusa o assalariamento, porém, o afirma viabilizando a ampliação e a reprodução do capital na circulação da mercadoria. As contradições presentes no migrante movem o processo produtivo no modo de produção capitalista e é dessa maneira que ele busca a sua inserção em São Paulo. 


\section{BIBLIOGRAFIA}

ALBERTI, Verena. História Oral: a experiência do CPDOC. Rio de Janeiro: Editora da FGV, p. 45-100, 1990.

ALBUQUERQUE JR., Durval Muniz. "Paraíbas e Bahianos: órfãos do campo filhos legítimos da cidade”. In: Travessia, São Paulo: Centro de Estudos Migratórios. São Paulo no 8, p. 27-32, set./dez.1990.

ÂNGELO, Assis. "A presença dos Cordelistas e Cantadores Repentistas em São Paulo”.In: Cidade . Ano 2.São Paulo: Departamento do Patrimônio Histórico. 1995

A presença dos Cordelistas e Cantadores Repentistas em São Paulo .São Paulo: IBRASA, 1996. 123 p.

ANDRADE, Margarida Maria de. "Bairros Além-Tamanduateí: o imigrante e a fábrica no Brás, Moóca e Belenzinho”. Tese de Doutorado em Geografia. Departamento de Geografia da FFLCH - USP. São Paulo: 1991. . "Brás, Moóca e Belenzinho - 'bairros italianos' na São Paulo além-

Tamanduatê̂”. Revista do Departamento de Geografia. FFLCH - USP. São Paulo, v.8, p.97-102, 1994. 252 p.

- "Brás, Moóca e Belenzinho, Formação e Dissolução dos Antigos

Bairros 'Italianos' Além Tamanduateí. In: Travessia, São Paulo: Centro de Estudos Migratórios, $\mathrm{n}^{\mathrm{o}}$ 38. p.5-10, set.-dez, 2000.

AYALA, Maria Ignez. No Arranco do Grito (Aspectos da Cantoria Nordestina). São Paulo: 1982. Tese de Doutorado da FFLCH da USP. p.29-97.

AZEVEDO, M. M. M., BAPTISTA, D. M. T. e VIDAL, M. S. C. “CTN - Um Nordeste Paulistano.” In: Travessia. São Paulo: Centro de Estudos Migratórios n³4, p. 39- 42, mai./ago, 1999.

BAPTISTA, Dulce M. T. Nas Terras do "Deus Dará"- Nordestinos e suas redes sociais em São Paulo. Tese de Doutoramento em Ciências Sociais. São Paulo. PUC, 1998. 324 p.

BERMAN, Marshall. Tudo que é sólido desmancha no Ar. Aventura da Modernidade. São Paulo: Companhia de Letras, 1987. 347 p. 
BARROS, N. C. "Migrações, Urbanização e Setor Informal: Estudo sobre as formas de comercialização em área de emigração para as metrópoles de São Paulo e Rio de Janeiro". In: Boletim Paulista de Geografia. São Paulo: AGB. p.105112. 1988.

BISON, Pessoa Wanderluce. A Volta por Cima-mulheres migrantes entre o Vale do Jequitinhonha e São Paulo. Dissertação de Mestrado em Geografia. Departamento de Geografia da FFLCH, USP, 1995. 78 p.

BOSCO, Santa Helena, JORDÃO NETO, Antônio. Migrações: estudo especial sobre as migrações internas para o Estado de São Paulo e seus efeitos. São Paulo, Secretaria da Agricultura do Estado de São Paulo, 1967. p. 1- 40.

CACCIAMALI, Maria Cristina. Setor Informal Urbano e Formas de Participação da Produção. IPE/USP. São Paulo. 1983.

CAMPELO, Glauce Maria da Costa. A Atividade de Confecções e a Produção do Espaço em Santa Cruz do Capibaribe. Dissertação de Mestrado em Geografia. UFPE, Recife: 1983 - 157 p.

CAPEL, Horácio. Filosofia y Ciencia en la Geografia Contemporânea. Barcelona: Editorial Barcanova S. A., p. 403-455. 1981.

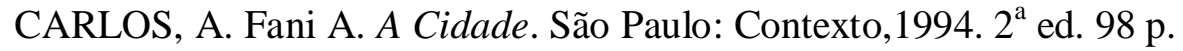

CARDOZO, José Eduardo. A Máfia das Propinas. Ed. Fundação Perseu Abramo.1996. 208 p.

CEM (Centro de Estudos Migratórios). Migrações no Brasil. Ed. Paulinas, São Paulo, 1980. $82 \mathrm{p}$. .Nordestinos. Cadernos de migração. Vol. 2. 1988. 38 p.

CHOI, Joa Keum. Além do Arco Íris: a imigração coreana no Brasil. Dissertação de mestrado em História. Departamento de História da FFLCH - USP. São Paulo: 1991.

DURHAN, Eunice. A Caminho da Cidade. São Paulo: Ed. Perspectiva.1973.

ESTRELA, Eli S. Os Sampauleiros do Alto Sertão da Bahia (Cotidiano e Representações). Dissertação de Mestrado em Geografia - Departamento de Geografia da FFLCH - USP. São Paulo: 1999. 209 p. 
EVERS, Tilman et alii. "Movimentos de Bairro e Estado: lutas na esfera da reprodução na América Latina". In: Cidade, Povo e Poder. Rio de Janeiro: CoEdições. CEDEC/Paz e Terra, 1982.

FREITAS, Sonia Maria de. E Chegam os Imigrantes... São Paulo: Editora Chevalier, 1999.

FUNDAÇÃO DE INFORMAÇÕES PARA O DESENVOLVIMENTO DE PERNAMBUCO/FIDEPE - Santa Cruz do Capibaribe. Série Monografias Municipais. Governo da Secretaria de Planejamento. Recife, 1982.

FURTADO, José Maria. “Aqui não se paga imposto”. In: EXAME, São Paulo: Abril. Ano 35, n³, fev., p. 96 - 99. 2001.

GAUDEMAR, Jean Paul de. A Mobilidade do Trabalho e Acumulação do Capital. Portugal: Editora Estampa, 1977. 404 p.

GOMES, Sueli de Castro. “'Vila do Pano': Nos interstícios da indústria, o pequeno comércio do Brás”. In: Relatório do CNPQ. São Paulo. 1990. 47 p.

HARVEY, David. Condição pós-moderna. Uma pesquisa sobre as Origens da Mudança cultural. $2^{\text {a }}$ ed. São Paulo. Loyola, 1993.

HASBAERT COSTA, Rogério Gaúchos no Nordeste. Modernidade, Desterritorialização e Identidade. Tese de Doutorado em Geografia Departamento de Geografia da FFLCH - USP. São Paulo: 1995

" "Desterritorialização: entre as redes e os aglomerados de exclusão". In: Geografia: Conceitos e Temas. Rio de Janeiro: Bertrand Brasil, p.165-205, 1995.

JACQZ, Irene. Integração dos Imigrantes Nordestinos em São Paulo: assimilação ou não. São Paulo (mimeo). 1982.

JAKOBSEN, MARTINS e DOMBROWSKI (orgs.). Mapa do Trabalho Informal.

São Paulo: CUT e Ed. Fundação Perseu Abramo, 2000.

KRISIS, Grupo. Manifesto Contra o Trabalho. Geousp - Labur. Tradução Heinz Dieter Heidemann. São Paulo. Cadernos do Labur .1999. 90 p.

KURZ, Robert. O Colapso da Modernidade. São Paulo: Paz e Terra.1992. 244 p. Os Últimos Combates. São Paulo: Ed. Vozes.1997. 391 p. 
"Dominação sem sujeito". In: PAIVA, Jorge (org.). Seminário Internacional: teoria crítica radical, a superação do capital e a emancipação. Fortaleza. 2000. p. 151-229.

LANGENBUCH, J. R. A Estruturação da Grande São Paulo - estudo de Geografia Urbana. Rio de Janeiro, IBGE, 1971.

LEGASPE, Luciano. Reciclagem: a fantasia do eco-capitalismo. Dissertação de Mestrado em Geografia - Departamento de Geografia da FFLCH - USP. São Paulo: 1996.

LENCIONE, Sandra. Restruturação Urbano-Industrial: centralização do capital e desconcentração da metrópole de São Paulo - indústria têxtil. Tese de Doutorado em Geografia - Departamento de Geografia da FFLCH - USP. São Paulo: 1991.

LIMA, T. T. de. "O pequeno e o grande comércio - elementos teóricos". In: Boletim Paulista de Geografia. São Paulo, no 65, p.121-125. 1987.

MACHADO, Antônio de Alcântara. Brás, Bexiga e Barra Funda. São Paulo: Ed. Nova Alexandria, 1995.

MARIANO, Neusa de Fátima. O Migrante Comerciante de Rua da Praça da Sé Centro da Cidade de São Paulo. Trabalho de Graduação Individual - FFLCH USP - Departamento de Geografia, 1997

MARTIN, André Roberto. O Bairro do Brás e "A Deterioração Urbana". Dissertação de Mestrado em Geografia - Departamento de Geografia da FFLCH - USP, São Paulo: 1984. 187 p.

MARTINS, José de Souza. A Imigração e a Crise do País Agrário. São Paulo: Biblioteca Pioneira de Ciências Sociais, 1973.

O Cativeiro da Terra. São Paulo: Livraria e Editora Ciências Humanas, 1979.

.Migrações Temporárias: problema para quem?. In: Travessia. São Paulo: CEM, n. 1, p.5-8, 1988 a.

. "O Vôo das Andorinhas: migrações temporárias no Brasil". In: Não Há

Terra Para Plantar Neste Verão. O cerco das terras indígenas e das terras de 
trabalho no renascimento político do campo. Petrópolis: Vozes, p. 43-61,1988 b.

"Migrações Internas no Mundo Contemporâneo". In: Convivendo com o Diferente. Brasília: CSEM, p. 27-36, 1999.

. "O Problema das Migrações no Limiar do Terceiro Milênio". In: $O$ Fenômeno Migratório no Limiar do $3^{\circ}$ Milênio. Petrópolis: Ed. Vozes, p.19-34, 1998.

MARX, Karl. O Capital: crítica da economia política. Vol. 1 - $15^{\mathrm{a}}$ ed. - Rio de Janeiro: Bertrand Brasil, p.1-161. 1996.

MEDINA, Cremilda (org.). Forró na Garoa. CJE/ECA - USP. Col. São Paulo de Perfil - 4. 1989. 156 p.

MENEZES, Marilda Ap. "Trabalho por Conta Própria: sonho dos migrantes." Travessia. São Paulo: CEM, nº 8, p. 22-26, 1990.

- "Da Paraíba prá São Paulo e de São Paulo prá Paraíba."

Dissertação de Mestrado em Sociologia - UFPB. Campina Grande. 1985. p.1157.

MIGUEZ, Eduardo. "Microhistoria, Redes Sociales e Historia de Las Migraciones: ideas sugestivas y fuentes parcas". In Inmigracion y Redes Sociales en La Argentina Moderna. Org.: María Bjerg e Hernán Otero. Tandil: CEMLA IEHS, p. 23-34, 1995.

MONTEIRO, Bettina Duarte et. Alii. “Ambulantes do Largo 13”.In: Travessia. São Paulo. Centro de Estudos Migratórios, nº 16- p. 10 -13,maio-agosto 1993.

MUMFORD, Lewis. Perspectivas Urbanas. Buenos Aires: Ed. Emecé, p.93-120. 1969.

OLIVEIRA, Chistian D. M. de. "Terciarização e Espaço Metropolitano”. In: Boletim Paulista de Geografia. n 65. São Paulo: AGB. p. 49 - 57. 1987.

OLIVEIRA, Francisco de. Elegia para uma Re(li)gião. $3^{\text {a }}$ edição. Rio de Janeiro: Ed. Paz e Terra. 1981. 137 p.

PALMEIRA, Moacir G. Soares. Projeto Emprego e Mudança Sócio Econômica no Nordeste. Rio de Janeiro: UFRJ. 1977. 74 p. 
PENNA, Maura. O Que Faz Ser Nordestino: identidades sociais, interesses e o “Escândalo Erundina”. São Paulo, Cortez, 1992. p.1-113.

PENTEADO, Jacob. Belenzinho 1910. Ed. Martins. São Paulo. 1962.

PETRONE, Pasquale. A cidade de São Paulo no século XX. In: Revista de História n 21 e 22. Jan.-Jun. São Paulo - Brasil. 1955.

PÓVOA NETO, Helion. "Migrações Internas e Mobilidade do Trabalho no Brasil Atual. Novos desafios para a análise”. In: Experimental nº 2. p. 11 - 24, 1997.

PRADO JR, Caio. A Cidade de São Paulo - geografia e história. $2^{\circ}$ ed., São Paulo, Brasiliense, 1983.93 p.

PRANDI, Reginaldo. O Trabalhador por Conta Própria Sob o Capital - Coleção Ensaio e Memória - São Paulo: Ed. Símbolo. 1978. 165 p.

QUEIROZ, Maria Isaura Pereira. "Relatos Orais: do "Indizível" ao "Dizível". In: SIMSON, Olga Moraes (org.). Experimentos com Histórias de Vida. São Paulo, Vértice/ Editora Revista dos Tribunais, p. 14-43. 1988.

RAMELLA, Franco. "Por un Uso Fuerte Del Concepto de Red en Los Estudios Migratórios”. In: Inmigracion y Redes Sociales en La Argentina Moderna. Org. María Bjerg e Hernán Otero. Tandil: CEMLA -IEHS, p. 9-21, 1995.

RAMOS, Aluísio Wellichan. Industrialização e Desindustrialização na Metrópole Paulistana: o caso da Água Branca. Trabalho de Graduação Individual.FFLCH - USP - Departamento de Geografia. p. 1-128. 1998.

RAVENSTEIN, E. G. "As Leis da Migração". In: MOURA, Hélio A. de.(org). Migração Interna - Textos selecionados. Fortaleza: BNB, Tomo I, p.19-88, 1980.

REALE, Ebe. Brás, Pinheiros, Jardins - Três bairros, três mundos. São Paulo: Edusp, 1982.

SALIM, Celso Amorim. "Migração: o fato e a controvérsia teórica". In: VIII Encontro Nacional de Estudos Populacionais. Anais, Vol. 3, São Paulo, ABEP, p.119-144, 1992.

SANTOS, Milton. Pobreza Urbana. São Paulo: Hucitec.1979a. .O Espaço Dividido. São Paulo: Francisco Alves. Tradução de Myrna T. R. Viana. p. $23-54.1979$ b. 
SAYAD, Abdelmalek. A Imigração ou os Paradoxos da Alteridade. São Paulo: Editora da Universidade de São Paulo, 1998. 286 p.

SEABRA, Odette Carvalho de Lima Seabra. "Urbanização, Bairro e Vida de Bairro" in: Travessia. São Paulo: Centro de Estudos Migratórios, $\mathrm{n}^{0}$ 38. p.11-17, set.dez, 2000.

SILVA, Alexandre César Batista da. O Comércio em Caruaru: um pouco da História e como a globalização está influenciando (mudando) essa história. Monografia. FAFICA. Caruaru. 1998.

SILVA, André Luiz. A Feira de Caruaru. Monografia. FAFICA. Caruaru. 1998.

SILVA, Sidney A. da. Costurando Sonhos. Trajetória de um grupo de imigrantes bolivianos em São Paulo. São Paulo: Ed. Paulinas, 1997. 292 p.

SINGER, Paul. Economia Política da Urbanização. Ed. Brasiliense. $12^{\circ}$ edição (1973). São Paulo. 1990. 152 p.

. Desenvolvimento Econômico e Evolução Urbana. Companhia Editora Nacional. São Paulo. p.19 - 79, 1974.

SOUZA, Emanuel Bandeira - Nos porões dos Arrecifes - $O$ trabalho autônomo no comércio de confecções da cidade de Recife. Dissertação de Mestrado em Sociologia da UFPE. Recife. 1984

SOUZA, Avanísia e et alli. Sulanca - Aspectos Históricos, Econômicos, Políticos e Sócio-Culturais. João Pessoa. 1996. 71p.

VAINER, Carlos B. "A Violência como Fator Migratório: silêncios teóricos e evidências Históricas”. Travessia nº 25, p. 5-9, 1996.

. Política Migratória Recente no Brasil - Notas para uma avaliação. In: Colóquio Internacional "Estrutura de emprego e dinâmica espacial da força de trabalho. PUR/UFRJ. Rio de Janeiro, 1985. 24 p.

. Estado e Migrações no Brasil - anotações para uma história das políticas migratórias. In: Travessia $\mathrm{n}^{\circ}$ 36, p.15-32, jan.-abr. 2000.

VILLAÇA, Flávio. A Estrutura Territorial da Metrópole Sul Brasileira: áreas residenciais e comerciais. Tese de Doutorado FFLCH-USP - Departamento de Geografia, São Paulo, 1978. 358 p. 
WOORTMANN, Klaas A. W. “A Família Trabalhadora." Série Antropologia, nº 40 Mimeo. Brasília. p. $69-87,1984$.

\section{Artigos em Jornais:}

SP concentra shoppings de atacado.Folha de São Paulo, São Paulo (13.08.93), p.1 -2 Caderno: Tudo

Migrantes são 32,2\% da população da Grande São Paulo. Folha de São Paulo, São Paulo(22.08.1996). TOLEDO, José Roberto de .Caderno: Cotidiano

SP tem 52 terminais de ônibus clandestinos. Folha de São Paulo, São Paulo, (27.05.2001), p. 1 -3. Caderno: Cidade

Há escravos em São Paulo...O Estado de São Paulo, São Paulo, (18.03.2001) LAZO, Albino Ruiz. Caderno Cidades

Jornal Eco Nordestino - (São Paulo, outubro de 2001) - BEZERRA, Francis Jornal da Sulanca (Caruaru,01 a 30 de novembro de 2001)

.JUNIOR, Plínio Carnier.. Museu da Imigração, Catálogo. São Paulo, setembro de 1997

\section{Documentário:}

DUARTE, Neide. São Paulo-Memória em Pedaços-Brás, documentário da TV Cultura, 1997.

\section{Site pesquisados:}

www.ibge.com.br acesso em 8/2001

www.lojasdobrás.com.br acesso em 10/2001

$\underline{\text { www.sdescc.com.br acesso em 11/2001 }}$

www.geocities.com/sulanca acesso em 11/ 2001

\section{Cartas e Mapas:}

BALLANOTTI, J. L. e MARQUES, M. B. Atlas para definição de políticas sociais no Estado de São Paulo. São Paulo: SCFBES, 1994. 
CPTM, Companhia Paulista de Trens Metropolitanos, 2000.

EMPLASA, Empresa Metropolitana de Planejamento da Grande São Paulo, 1996 Folhas: 3321 e 3323. Escala: 1:10 000.

INSTITUTO DE PESQUISAS TECNOLÓGICAS, Base de Dados Geoambientais do IPT.1998.

SIMIELLI, Maria Helena. Geoatlas. São Paulo: Ática. 2001. 
ANEXOS 
SUMÁRIO

CORDÉIS 2

ROTEIRO GERAL DAS ENTREVISTAS 


\section{CORDÉIS}

\section{A MALANDRAGEM DO BRÁS - Lourival Bandeira}

"Meus caros e bons amigos, Prestem-me atenção, agora. Porquê, minha fraca pena, Para escrever não demora. E sabe reparar tudo, Que se passa a qualquer hora.

Desejei cassar um tema, Como fraco trovador. Uns falam de valentia, Já outros falam de amôr Eu descobri um motivo, Para o nobre e, bom leitor.

O motivo está na cara, Garanto que satisfaz. Em São Paulo, a vadiagem, Tudo fe ruindade tráz Por isso, eu escrevo agora, A malandragem do Bráz

É no "Largo da Concórdia", Que fica a maior porção:

Ali em qualquer lugar Do Colombo à estação, Depois das 23 horas

Tem mais mulher e, ladrão.

A polícia dá duro, Trabalha que causa espanto. Leva sempre carro cheio, P'raquele "sagrado canto". E quando passa no largo, Toda vez, vai outro tanto.

O que é interessante, E também causa pavor É que qualquer ladrão fino, Seja em que materia for Tem muito mais documento Que um homem trabalhador

No Bráz, depois das 10 horas Tem demais é cachaceiro, Vagabundo pilherista, Tem no largo o dia, inteiro; E de pouca confiança, Se andar no Bráz com dinheiro.

Ali robam bicicleta, Radio novo de primeira.
Carro, caneta, relogio,

De pulso e de algibeira. Em qualquer bar da Concordia Tem batedor de carteira.

Se atravessar a porteira, Deve ter muito cuidado, Que tem mulher vigarista Pingusso e ladrão fixado. E na rua Almeida Lima, Anda um bando organizado.

Ali o ponto é do norte, É um centro interessante, Transporte para o nordeste, Toda hora a todo instante. Más também tem outro tanto, De velhaco de assaltante.

(....)

Pois qualquer mulher daquela Pega o pobre do sertão. Ilude o rapaz e leva, No hotel, para o "Cantão". Lá o pobre deixa tudo, Pra ela e o ladrão.

Um moço do interior, Para o norte viajando, Demorou-se na Concórdia. Pelo horário esperando, Tudo que tinha roubaram, voltou pra roça chorando

Quantos inescrupulosos! Neste centro aventureiro, Quando havia "Páu-de-Arára" Procuravam passageiros, Davam-lhe passagem falsa E fugiam com o dinheiro.

(...)

Uns vendem bijoteria, Pois naquilo tem prazer Já outros só "vendem pente", E a noite que vão fazer? Dez, doze pentes por dia Não dá para ninguém viver. 
Porisso é que aumenta o número

De homem desajustado;

Dando trabalho a polícia

Deixando o povo assustado,

Esse povo sem princípio,

Necessita de cuidado

(...)

Temos malandro "devoto"

Que faz roubo até a missa

Passa o "conto" da preguiça

O "paco do Paroará"

Do "garoto"e da "curtiça".

(...)

Agora toda essa gente,

Quando estivesse pegada,

Em determinado plano,

Ela fosse castigada.

Nos serviços, nas escolas,

A terra estava guardada!

Não é somente nas fábricas

Que se pode trabalhar;

Pois o bom intensionado,

Trabalha em qualquer lugar.

Tudo faz "economia"

$\mathrm{E}$ a noite pode estudar.

Assim São Paulo seria

Igualmente a um "ceu aberto"

Sem tarados sem malandros,

Sem vigaristas por certo;

Talvez morresse o ditado

O "mundo é do mais esperto".

Ah! Se o governo criasse

Uma nova instituição,

Escola pra esses homens,

Sem luz e sem fomação,

E só desse a liberdade,

Depois da compreensão!

Pois do contrário não há,

Quem acabe a malandragem

Fator principal do povo,

Trabalha na disvantagem.

Pois até contra a polícia,

Esses malandros reagem.

(...)

Eu não digo que no Brás,

Tenha somente ladrão

Não!... que no Brás tem famílias

Que tem alta posição.

Sujeitas a esses ratões,

Dona da destruição.
O Brás é um bairro fino,

De gente boa e dinheiro,

É justamente porisso,

Que os ladrões do mundo inteiro,

Deixa seus esconderijos

E no Brás fazem puleiro.

Eu falei só dos malandros,

Nunca da sociedade.

Pois só disse o que se passa,

E tenho capacidade

Para descer a caneta,

Quando houver necessidade.

Pois não fiz este folheto

Para adquirir cartaz.

Porque do jeito que fiz,

Qualquer um querendo faz.

Basta observar tres dias,

A malandragem do Brás. 
FEIRA DA SULANCA - José Augusto Maia

Acorda Zé, são três horas da manhã

Pega o saco, amarra a boca e cai no mundo pra vender

Vai no outro quarto e avisa pras meninas

Que o patrão lá na esquina

tem serão pra elas fazer

Desce a cidade no rugido da carroça

Gente da rua e da roça

Todo mundo vai descer

Lá na cidade até parece um formigueiro

Já tem tanto sulanqueiro esperando comprador

Um vem que compra, outro vende, outro se arranca

Todos têm a esperança que um dia chegam lá

E o movimento se transforma em fatura

Dando cores à costura que pra longe vão levar

Esta cidade já viveu de outra cultura

Mas nunca teve fartura, o jeito mesmo foi mudar

É Santa Cruz, Pernambuco te exibe

Orgulho do Capibaribe

Um exemplo nacional

O seu trabalho rende muito e dá fruto

Se encontra em qualquer reduto e até na capital

Já tomou rumo se estendeu pelo agreste

Tem tanto "cabrá da peste"entrando no Buruçu

De toritama, descambou saiu sorrindo

Se juntou com Vitalino na Feira de Caruaru

É vendedor grita na banca

É comprador chega se espanta com as vantagens

Que oferece o feirante da sulanca

Calça, camisa, manga curta e manga longa

Macaquito e camiseta, meia, gorro e minhocão

Tem jardineira, Almofada, tem bermuda

Mini-saia e mini-blusa, camisola e macacão

Maiô, Biquini, tem suquini, tem sacola

Tem também saia de bola, shote, tanga e cobertor, $\mathrm{t}$

em mosqueteiro, conjuntim de batizado

Tem a colcha de retalhos... onde tudo começou

É Santa Cruz, Pernambuco te exibe

Orgulho do Capiberibe

Um exemplo Nacional 


\section{A VIDA DO SULANQUEIRO - Isaura de Melo Souza}

A vida do sulanqueiro

É uma vida aperriada

Segunda Feira meio dia

Vem marcar sua calçada

$\mathrm{O}$ rapa vem com a peste

Leva tudo não deixa nada

Eu também sou sulanqueira

Fico no meio da calçada

Sentindo aquele cheirinho

Daquela carninha assada

Tem dia que não discolo

Volto pra casa sem nada

Eu conheço sulanqueiro

Muito forte e tem padrão

Tem seu banco na esquina

Fatura mais de um milhão

E o pobre lá na calçada

Brigando pelo um tostão

A vida do sulanqueiro

Oh que vida desgraçada

Para ganhar o seu pão

Dorme a noite na calçada

enfrentando chuva e frio

E sereno da madrugada

Eu conheço sulanqueiro

Que está muito apavorado

Recebeu cheque sem fundo

Que veio de outro estado

Já vendeu tudo que tinha

Coitadinho está quebrado

Ror isso que já parei

De ficar nessa ilusão

Toda terça eu ia feira

Dormia no calçadão

O dinheiro que trazia

So dava pra comprar pão

É uma agonia danada

De quem vive ali no chão

Fica vendendo assustado

Para ganhar o feijão

Quando vem o segurança

Leva tudo não tem perdão

O cabra perdeu a feira

Dinheiro não vai ganhar

Só esperança a ordem

Para o grandão liberar

Além de ter prejuízo

Ainda tem que pagar
Eu aviso a todo mundo

O lugar que é proibido

Tem gente bem malcriado

Cabeçuda e maluvido

Bota no lugar errado

Porque é muito atrevido

Eu também quero falar

Do pobre do carroceiro

Quando aparece um freguês

Cada um que vai primeiro

Para levar o seu malote

E ganhar algum dinheiro

Feira grande é da sulanca

É a mais linda do mundo

O que você quer comprar

Encontra logo em segundo

Mais tenha muito cuidado

Ao toque do vagabundo

Tem tanto ladrão aqui

Ainda vem mais de fora

Lhe corta a bolsa e o romba

Sem dó leva e vai embora

Eu para não ser roubado

So peço a Nossa Senhora

Agora eu vou falar

Daquele bem pirangueiro

Com saco grande nas costas

Este é que tem dinheiro

Procurando o mais barato

Sem achar o seu roteiro

Fica prá lá e pra cá assim passa o tempo inteiro o mala já está de olho nào fica por derradeiro passa os 2 dedos no bolso carrega todo o dinheiro

A choradeira começa Isto foi a uma hora

Tinha tanta encomenda

Ai meu Deus que faço agora

Sem poder tomar café

E como posso i r embora

Tá ai o resultado

De quem fica procurando

Faça logo sua compra

Deixe de ficar andando 
Seja uma pessoa alerta

Eu estou lhe avisando

E a gente que vem de longe

Só volta no outro dia

Com uma toalha no ombro

Pra ele é uma alegria

Mais quando Está chovendo

Perdeu a mercadoria

E aquele sabidinho

De buxo colado ao banco

Com a bolsa de boca aberta

Cabe um cento de tamanco

Roubando mercadoria

Quando eu pego dou um tranco

Engraçado é aquele

Que vem a primeira vez

Só anda em lote de doze

Ali já se perdeu seis

Só escuta uma gritando

Ai meu Deus quedê Inês

Também conheço lojista

Com orgulho e muita panca

Viu tanta gente na feira

disse eu perco a tamanca

Para vender seu estoque

Jogou no meio da sulanca

Sta. Cruz bem conhecida

Vem gente de todo lugar

Mais todo mundo assustado

Que o assalto é de lascar

Sabe se vai voltar

Isto mesmo se ocorre

Aqui em Caruaru

Viaje e tenha cuidado

Esconda bem o seu tutu

Que o cabra leva sem dó

Ainda lhe deixa nú

No ônibus foi assalto

Guardei a grana primeiro

Pensei que estava seguro

O ladrão sentiu meu cheiro

disse assim manda gatinha

Passou a mão no dinheiro

Uma mocinha guardou

Seu dinheiro sem receio

Bem apoiada e sentada

Lá na cadeira do meio

O ladrão viu o lugar

E fique na paz do Senhor
Levou a grana e o seio

Um rapaz junto de mim

Abraçado com a mulher

Vinha comendo biscoito

Tomando o seu café

Com a grana dentro da meia

O ladrão viu e torou o pé

Engraçado o motorista

Era gordo e bem careca

O ladrão gritou bem alto

Tira logo sua beca

Ainda teve dó dele

Deixou ele de cueca

Eu nunca mais viajei

O medo foi de lascar

Sentado ali na cadeira

Sem poder a me levantar

Foi grande a dor de barriga

Não precisa de contar

Muita gente igual a mim

Está muito revoltado

Porque não tem segurança

Aqui dentro do estado

Quem compra está com medo

Quem vende está lascado

Ninguém vive mais em paz

Por causa da inflação

Todo dia sobe as coisas

Igual sobe foguetão

Por causa do tal Collor

Aquele cabra ladrão

Pedi pra não votar nele

Foi todo mundo avisado

Agora aguente o pipino

Descasque bem descascado

Tá vendo ai que se deu

Está todo mundo lascado

Agora quero lembrar

De quem fala com amor

$\mathrm{Na}$ sulanca e difusora

Sua voz me encantou

Carlos Augusto é seu nome

Um famoso locutor

Eu agora me dispeço

Desculpe se não gostou

Que foi da minha autoria

É feito com muito amor

Teve um pra seu amigo 


\section{ROTEIRO GERAL DAS ENTREVISTAS}

\section{Os comerciantes de retalho}

1- NOME:

\section{LOCAL DE ORIGEM:}

Tema: análise da sua estratégia de sobrevivência.

- Quando veio para São Paulo?

- Logo que chegou você veio morar no Brás ou trabalhar?

- O que te trouxe até o Brás?

- Você já sabia dessa atividade na sua cidade?

- Você veio trabalhar nessa atividade, logo que chegou à São Paulo ou

- teve outros empregos anteriormente? Quais foram?

- Conte como foi a sua entrada nessa atividade? Já tinha ouvido falar dela antes? Como foi que você conheceu essa atividade?

Tema: funcionamento, organização da atividade

- Para onde vai a mercadoria de sua atividade?

- Como funciona a atividade?

- Quanto custa hoje o carreto da perua?

\section{Tema: trabalho autônomo}

- Você prefere trabalhar por conta própria ou foi obrigado? Por quê?

- Quando foi que você começou a trabalhar por conta própria? Sempre trabalhou por conta?

- Precisa de algum capital para começar?

- Quais são as vantagens dessa atividade?

- Quais as dificuldades que vocês enfrentam nessa atividade?

- O que significa essa atividade autônoma para você?

- Quais são seus sonhos e expectativas para o futuro?

- Quando você veio para São Paulo, quais eram seus sonhos e expectativas?

Você conseguiu realizá-los?

\section{Tema : A relação entre esses migrantes}

- Essa loja é sua ou você trabalha junto com alguém?

- Você é registrado? Você já trabalhou como informal?

- Que tipo de problemas vocês têm aqui?

- Fale um pouco do seu dia-dia nessa atividade? Você gosta?

- Quantas Horas de trabalho por dia? Problemas com fiscal? Ladrão?

- Sua família trabalha junto com você? Por quê?

\section{Tema: as redes sociais que estão engendradas nessa atividade.}

- Quando chegou à São Paulo, você já conhecia alguém ou veio sozinho? 
- Quem foi que te colocou nessa atividade? Ele é parente, amigo? Quanto tempo ele o conhece? Vocês já se conheciam antes de vir para São Paulo?

- Explique melhor como ele pode te "ajudar"? ( Deu conselhos, indicou lugares, capital etc)

- Por que você acha que ele te colocou nessa atividade?

- E você já "ajudou" alguém nessa atividade? Quem são essas pessoas? Por que resolveu colocá-las nessa atividade?

- Como você colocou elas nessa atividade?

- Você se arrependeu de ajudá-las?

- Você mantém contato com elas até hoje? Como?

- Existem pessoas chegando do nordeste atualmente que estão entrando nesse comércio?

- Você ajudaria alguém, hoje para entrar nessa atividade? Por quê?

- Você já teve algum problema com um conterrâneo seu nessa atividade? Como foi? 


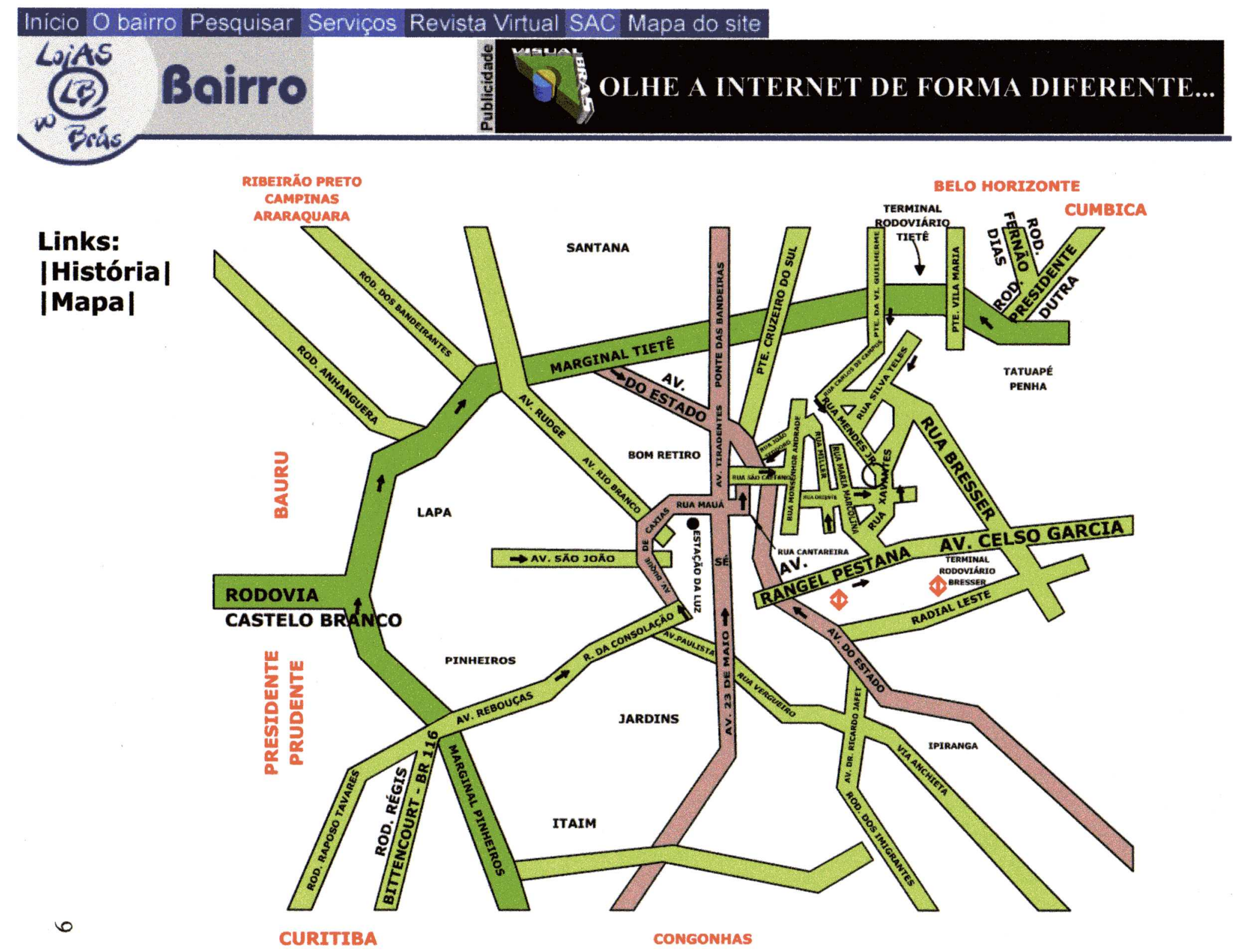

2 